Aus dem Fachgebiet Pflanzenpathologie und Pflanzenschutz

des Departments für Nutzpflanzenwissenschaften

der Georg-August-Universität Göttingen

\title{
Entwicklung eines Verfahrens zum biologischen Abbau des Inokulums strohbürtiger pilzlicher Pathogene im Getreide- und Rapsanbau auf Basis des pilzlichen Antagonisten \\ Microsphaeropsis ochracea
}

\author{
Dissertation \\ zur Erlangung des Doktorgrades \\ der Fakultät für Agrarwissenschaften \\ der Georg-August-Universität Göttingen
}

vorgelegt von

Martin Stadler

geboren in Regensburg

Göttingen, im Mai 2010 
D 7

1. Referent: Prof. Dr. Andreas von Tiedemann

2. Referent: Prof. Dr. Petr Karlovsky

Tag der mündlichen Prüfung: 15. Juli 2010 


\section{Inhaltsverzeichnis}

Abkürzungen und Symbole..................................................................................

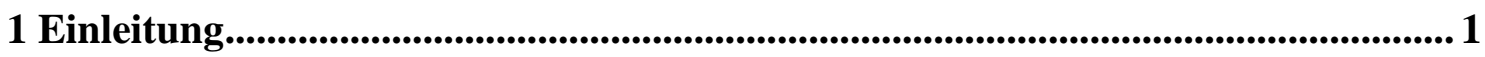

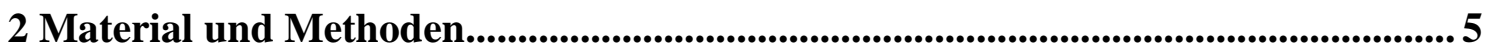

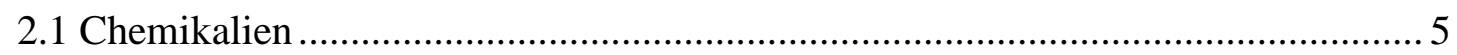

2.2 Nährmedien, Pufferlösungen und Trenngele .................................................... 6

2.3 Vermehrung und Erhaltung von Pilzmaterial .................................................... 11

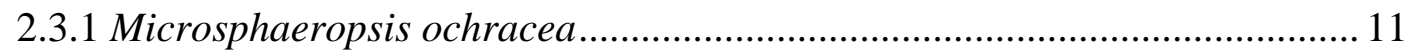

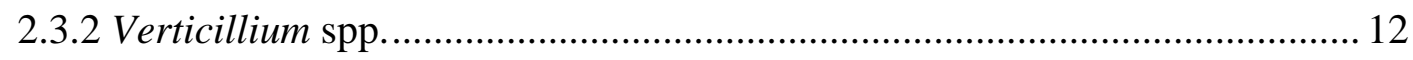

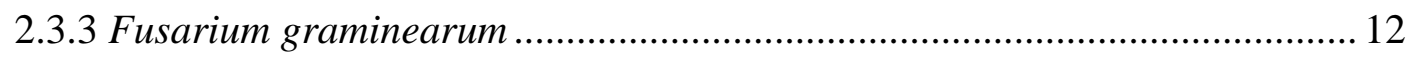

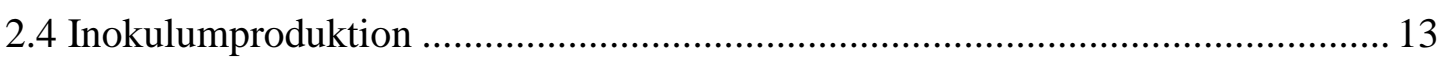

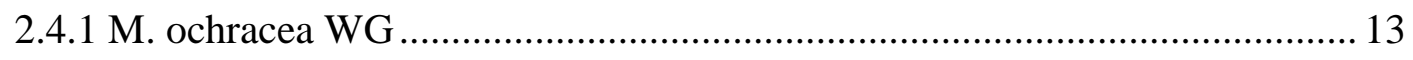

2.4.2 Mikrosklerotienproduktion von Verticillium spp. auf sterilen

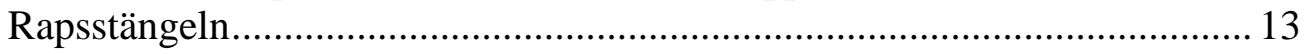

2.4.3 Mikrosklerotienproduktion von Verticillium spp. im Sandgemisch............... 14

2.4.4 Perithezienproduktion von F. graminearum auf Haferkörnern ...................... 14

2.5 Visuelle Erfassung des Rapspflanzenbefalls mit V. longisporum ........................ 15

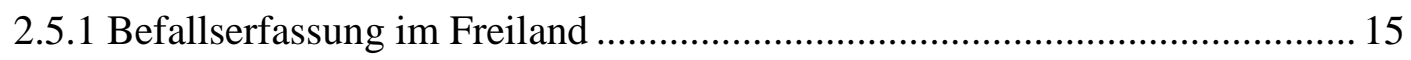

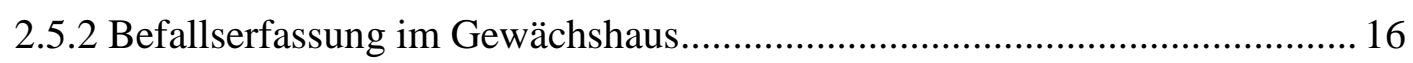

2.6 Visuelle Erfassung des Rapspflanzenbefalls mit Phoma lingam......................... 18

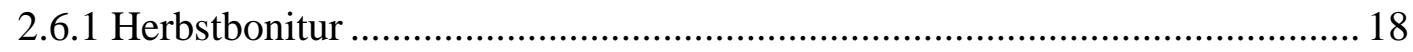

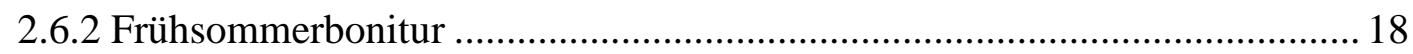

2.7 Visuelle Bonitur der Krankheiten an Winterweizen........................................... 20

2.8 PCR-Untersuchungen (Polymerase Kettenreaktion) .......................................... 20

2.8.1 Probenahme und Probenaufarbeitung........................................................ 20

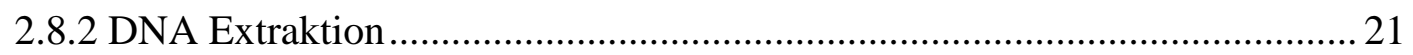

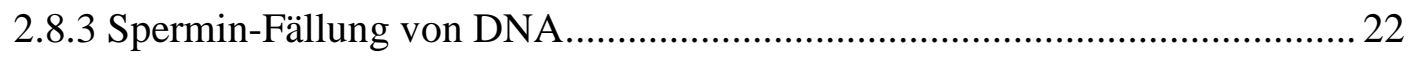

2.8.4 Quantifizierung der extrahierten DNA und Geldokumentation ..................... 22

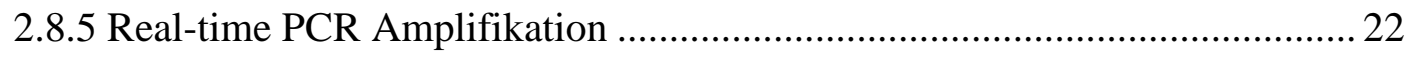

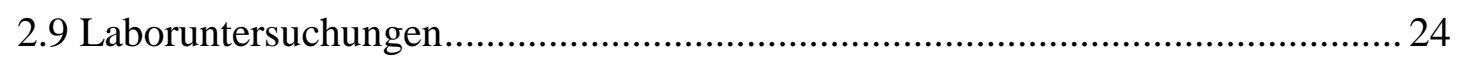

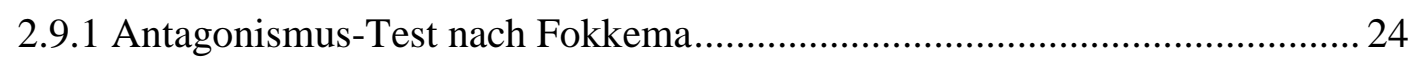


2.9.2 Keimtest mit Mikrosklerotien 25

2.9.3 Plattentest zur Überprüfung der mykoparasitischen Wirkung von M. ochracea auf Mikrosklerotien von Verticillium spp. in vitro.................... 25

2.9.4 Rapsstängelversuche mit $V$. longisporum und $M$. ochracea.......................... 26

2.9.5 Interaktion von $M$. ochracea mit F. graminearum in vitro ........................... 27

2.9.6 Quarkschalentest mit $V$. longisporum und $M$. ochracea ............................... 28

2.9.6.1 Bestimmung der maximalen Wasserhaltekapazität (WHK).................... 28

2.9.6.2 Interaktion von M. ochracea mit V. longisporum im Boden .................. 28

2.9.7 Wirkung der Bodenfungistasis auf die Sporenkeimung von

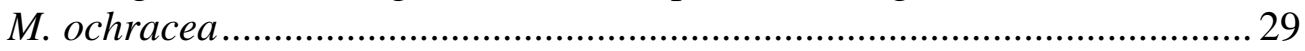

2.10 Entwicklung einer PCR zum Nachweis von M. ochracea................................ 30

2.10.1 Anzucht von M. ochracea und DNA-Extraktion....................................... 30

2.10.2 Amplifikation der „Internal Transcribed Spacer“ Region ............................ 31

2.10.3 Extraktion von DNA-Fragmenten aus Agarosegelen ................................. 32

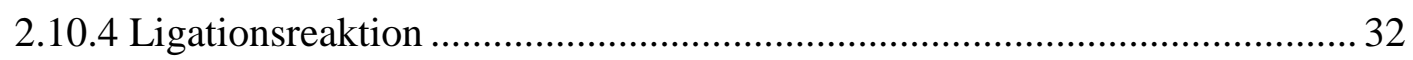

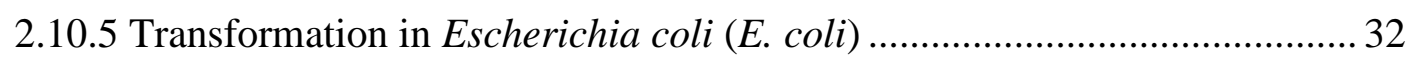

2.10.6 Isolierung von Plasmiden aus E. coli......................................................... 33

2.10.7 Ethidiumbromid-Phenolextraktion ............................................................. 33

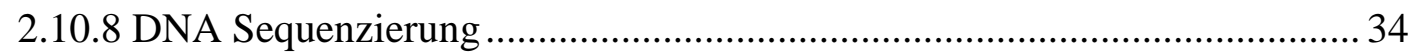

2.10.9 Nachweis von M. ochracea mittels PCR ................................................... 34

2.10.9.1 Primerdesign, PCR-Optimierung und Spezifitätstestung ...................... 34

2.10.9.2 PCR Reaktionsmix und Amplifikationsbedingungen............................ 34

2.11 Gewächshausversuche mit V. longisporum und M. ochracea ............................ 35

2.11.1 Pflanzenanzucht und Wachstumsbedingungen............................................. 35

2.11.2 Inokulationsstufenversuch mit Mikrosklerotien von $V$. longisporum .......... 37

2.11.3 Bodeninokulation mit M. ochracea WG als Granulat................................. 37

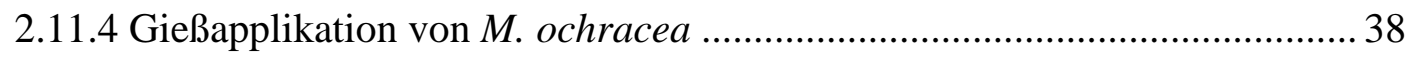

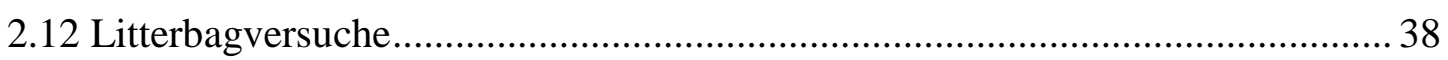

2.12.1 Abbau des Inokulums von V. longisporum durch M. ochracea .................. 38

2.12.2 Reproduktion von M. ochracea auf Rapsstroh im Freiland......................... 40

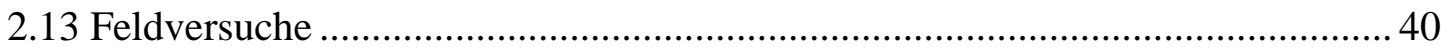

2.13.1 Standorte und meteorologische Daten ...................................................... 41

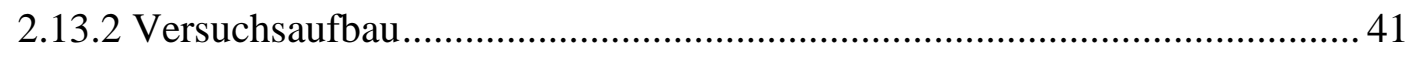

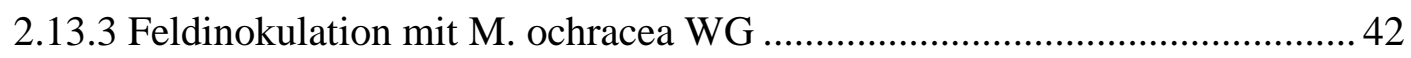

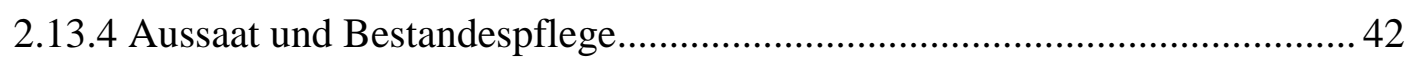

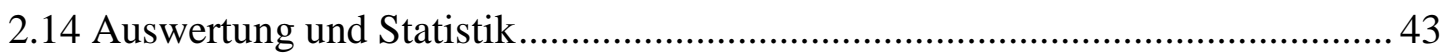




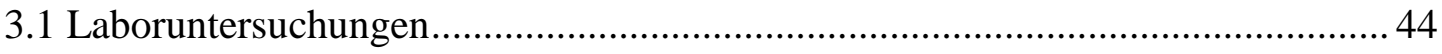

3.1.1 Hemmung des radialen Myzelwachstums durch M. ochracea ...................... 44

3.1.2 Mikrosklerotienkeimung und Mikrosklerotienbildung bei Verticillium spp. in Abhängigkeit von der Temperatur.................................................... 45

3.1.3 Keimhemmende Wirkung von M. ochracea auf Mikrosklerotien von

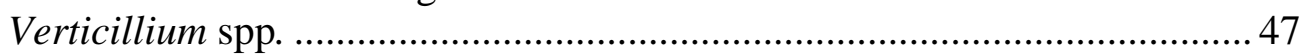

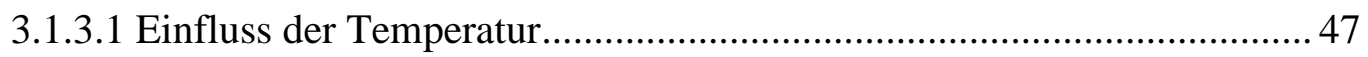

3.1.3.2 Einfluss der Sporendichte von M. ochracea und der

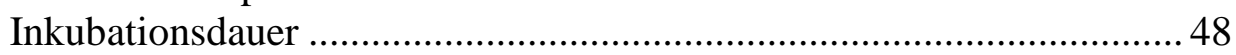

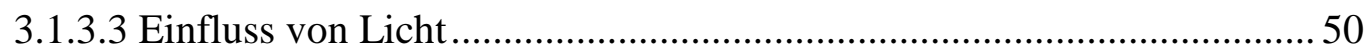

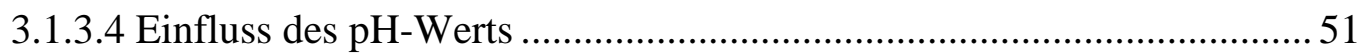

3.1.3.5 Bedeutung der Verticillium-Art und der Inkubationsdauer .................... 52

3.1.4 Interaktion zwischen $M$. ochracea und V. longisporum auf sterilen

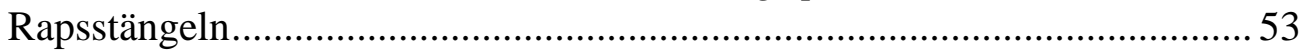

3.1.4.1 Koinokulationsversuch mit $M$. ochracea und $V$. longisporum ............... 53

3.1.4.2 Abbau von $V$. longisporum Mikrosklerotien auf Rapsstängeln nach Behandlung mit M. ochracea ............................................................... 54

3.1.5 Interaktion von M. ochracea und V. longisporum im Boden ....................... 56

3.1.6 Reproduktion von M. ochracea in Abhängigkeit vom Licht.......................... 58

3.1.7 Wirkung der Bodenfungistasis auf die Sporenkeimung von

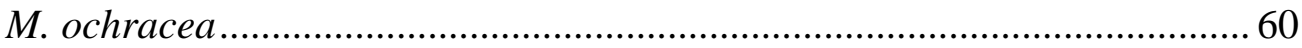

3.1.8 Interaktionsversuche mit F. graminearum und $M$. ochracea in vitro............. 62

3.2 Nachweis von M. ochracea mittels artspezifischer PCR.................................... 65

3.2.1 Entwicklung spezifischer Primer für M. ochracea ....................................... 65

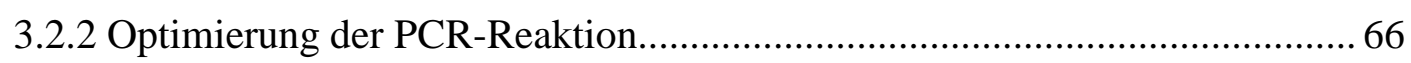

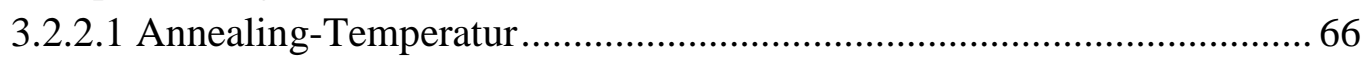

3.2.2.2 Magnesiumkonzentration und Nachweisgrenze für M. ochracea .......... 66

3.2.3 Spezifität der Primer M.o 3.1 und M.o 4.1.1 ............................................ 67

3.3 Gewächshausversuche mit V. longisporum und M. ochracea ............................ 69

3.3.1 Inokulationsstufenversuch mit Mikrosklerotien von $V$. longisporum ............ 69

3.3.2 Bodeninokulation mit M. ochracea WG als Granulat................................. 71

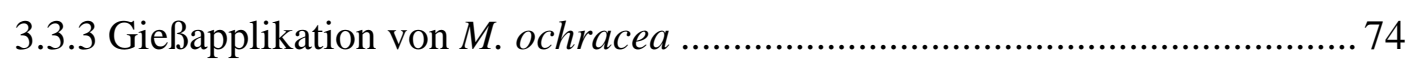

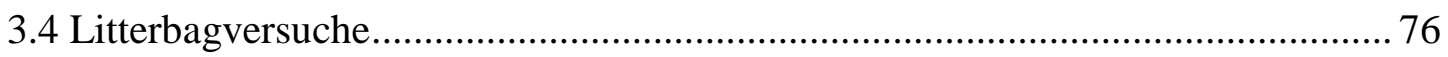

3.4.1 Abbau von V. longisporum durch M. ochracea im Boden ........................... 76

3.4.2 Reproduktion von M. ochracea auf Rapsstroh im Freiland........................... 82

3.5 Feldversuche zum Abbau des Pathogeninokulums durch M. ochracea ................ 84

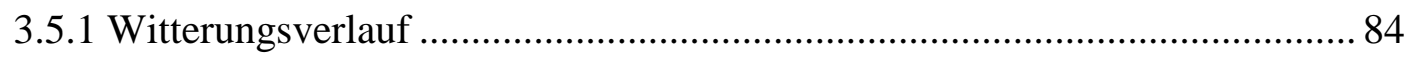


3.5.2 Einfluss von $M$. ochracea auf den pilzlichen Pathogenbefall im Winterweizen Monokulturanbau 86

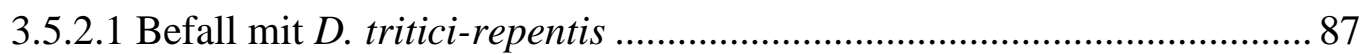

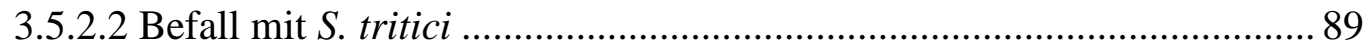

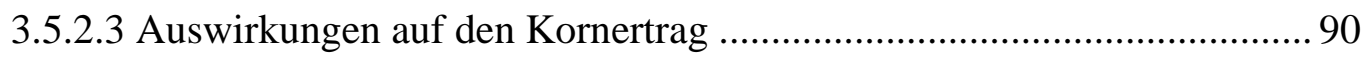

3.5.3 Einfluss von $M$. ochracea auf den Pathogenbefall im Winterraps

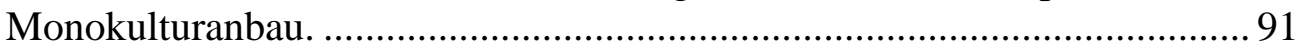

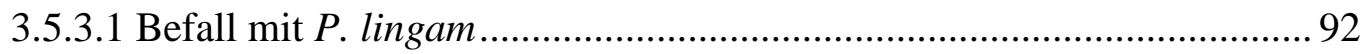

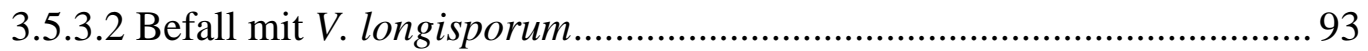

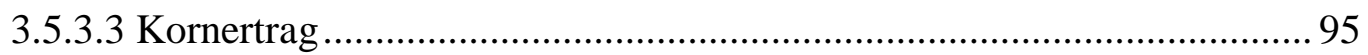

3.5.4 Einfluss von M. ochracea auf den Pathogenbefall in einer WinterrapsWinterweizen Fruchtfolge......................................................................... 95

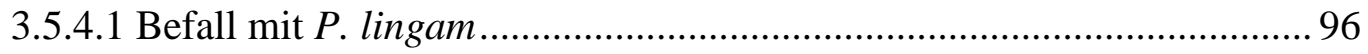

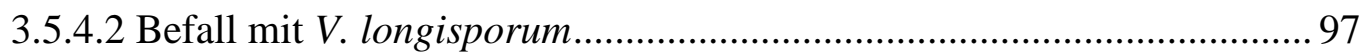

3.5.4.3 Auswirkungen auf den Kornertrag ...................................................... 97

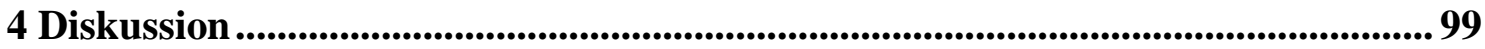

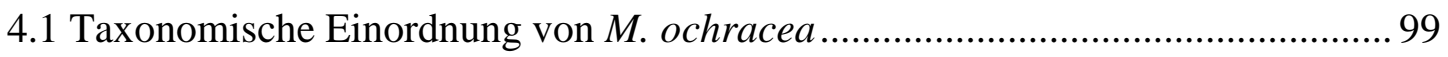

4.2 Antagonistische Wirkmechanismen von M. ochracea ..................................... 100

4.3 Interaktionsstudien zwischen Pathogenen und M. ochracea in vitro .................. 102

4.4 Polymerase Kettenreaktion zum Nachweis von M. ochracea ............................ 109

4.5 Gewächshausversuche mit V. longisporum und M. ochracea ........................... 112

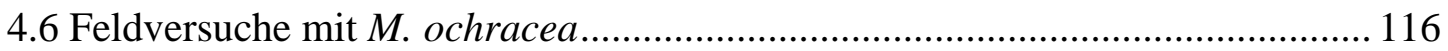

4.7 Interaktion zwischen M. ochracea und V. longisporum im Boden .................... 120

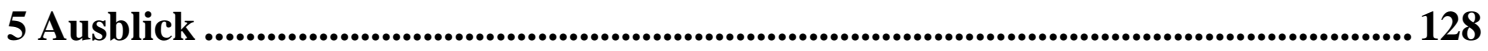

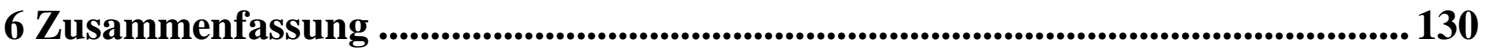

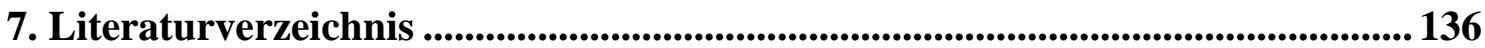

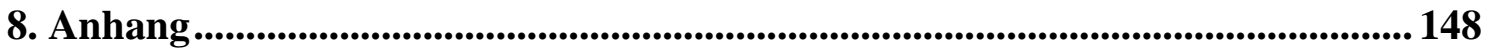




\section{Abkürzungen und Symbole}

Abb.

$\mathrm{BBCH}$

Bidest.

BW

bzw.

${ }^{\circ} \mathrm{C}$

ca.

$\mathrm{cm}$

d

DNA

dt

dpi

Fa.

g

$\mathrm{h}$

ha

$\mathrm{Hz}$

$\mathrm{kg}$

l

M

Mio.

$\mathrm{mM}$

$\mathrm{m}$

$\mathrm{m}^{2}$

mg

$\mathrm{ml}$

$\min$

$\mathrm{mm}$

$\mathrm{N}$

ng

$\mathrm{nm}$

n.s.
Abbildung

Codierung der phänotypischen Entwicklunsstadien

Doppelt destilliert

Befallswert

Beziehungsweise

Grad Celsius

zirka

Zentimeter

Tage

Desoxyribonukleinsäure

Dezitonne

days post inoculation

Firma

Gramm

Stunde

Hektar

Hertz

Kilogramm

Liter

Mol

Millionen

Millimol

Meter

Quadratmeter

Milligramm

Milliliter

Minute

Millimeter

Normal

Nanogramm

Nanometer

nicht signifikant 
o.g.

PCR

PFL

$r$

$\mathrm{R}^{2}$

rpm

$\mathrm{S}$

S.o.

Sp

SPKR

STM

Tab.

Taq

z.B.

$\mathrm{U}$

$\mu \mathrm{g}$

$\mu l$

Wdh.

$\%$ oben genannt

Polymerase Kettenreaktion

Pflanzenlänge

relativ

Bestimmtheitsmaß

Umdrehungen pro Minute

Sekunde

siehe oben

Spore

Sporenkeimrate

Sprosstrockenmasse

Tabelle

Thermus aquaticus

zum Beispiel

Unit

Mikrogramm

Mikroliter

Wiederholung

Prozent 


\section{Einleitung}

In den letzten Jahren hat sich in der Landwirtschaft ein rasanter Strukturwandel vollzogen. Dieser führte zu einem stetigen Wachstum und einer Spezialisierung der Betriebe. Dabei haben sich Ackerbaubetriebe auf den Anbau weniger Kulturpflanzenarten spezialisiert. Somit nahm der Anbau von Getreide und Raps stetig zu. Im Jahr 2008 wurden von den 11,9 Mio. ha Ackerfläche in Deutschland 7 Mio. ha mit Getreide und 1,5 Mio. ha mit Raps bestellt (Statistisches Bundesamt, 2008; Ufop, 2009). Dies führt zu immer engeren Fruchtfolgen in Raum und Zeit und in vielen Ackerbaubetrieben besteht die Kulturfolge daher nur noch aus Winterraps und Winterweizen.

Darüber hinaus hat die pfluglose Bodenbearbeitung stark an Bedeutung gewonnen und es wird in manchen Betrieben vollständig auf den Pflugeinsatz verzichtet. Gründe dafür sind in einer deutlichen Reduktion der Bodenbearbeitungskosten, einer Erhöhung der Schlagkraft und einem besseren Erosionsschutz zu suchen (Reich \& Wurlitzer). Ab dem Jahr 2010 ist der Pflugverzicht sogar politisch gewollt. Im Rahmen der Cross Compliance Verpflichtungen wurden alle landwirtschaftlichen Flächen in einem „Erosionskataster“ erfasst, so dass ab 2010 der Pflugeinsatz auf erosionsgefährdeten Flächen nur noch bedingt erfolgen darf. Teilweise muss vollständig auf den Einsatz des Pfluges verzichtet werden (Landesamt für Umwelt Landwirtschaft und Geologie Sachsen, 2009).

Die Kombination aus eng gestellten Fruchtfolgen in Verbindung mit einer reduzierten Bodenbearbeitung kann zu schwerwiegenden phytosanitären Problemen führen. So kommt es zu einer Anreicherung von Unkrautsamen in der oberen Bodenschicht und der Unkrautdruck kann nur durch intensive Herbizidstrategien kontrolliert werden. Weiterhin werden Ernterückstände nicht mehr in den Boden eingearbeitet. Hierdurch kommt es zu einer Anreicherung des Inokulums von stroh- und bodenbürtigen phytopathogenen Pilzen in der oberen Bodenschicht bzw. auf der Bodenoberfläche, welches den Pathogenbefall der Folgekultur begünstigt. (Vogt \& Kirchner, 2006; Balgheim, 2006; Beer, 2005).

Seit einigen Jahren bestehen auf nationaler und europäischer Ebene Bestrebungen den Einsatz chemischer Pflanzenschutzmittel zu reduzieren. Ziel ist es, negative Einflüsse chemischer Pflanzenschutzmittel auf die Umwelt, den Anwender und die Verbraucher 
zu minimieren (BMVEL; BMELV, 2008). Deshalb wird in den nächsten Jahren im Umfang der EU-Pflanzenschutzmittelpolitik das Wirkstoffspektrum chemischer Pflanzenschutzmittel und somit auch fungizider Wirkstoffe deutlich reduziert (Kleiner \& Eichel, 2009). Ein weiteres immer stärker auftretendes Problem beim Einsatz von chemischem Pflanzenschutz ist die Bildung von Resistenzen der Zielorganismen gegenüber den eingesetzten Wirkstoffen. Es wurde in den letzten Jahren eine vermehrte Selektion herbizidresistenter Unkräuter und fungizidresistenter phytopathogener Pilzstämme beobachtet. Die Ursachen hierfür sind in den enger werdenden Fruchtfolgen, verminderten Bodenbearbeitungsintensitäten und einem geringen Wirkstoffwechsel bei der Durchführung chemischer Pflanzenschutzmaßnahmen zu suchen (Feldstein \& Jaser, 2008; Mehl \& Stenzel, 2008; Balgheim, 2006).

Aufgrund der Resistenzproblematik und dem gesellschaftlichen Anspruch den chemischen Pflanzenschutzmitteleinsatz auf ein Minimum zu reduzieren, hat der „Integrierte Pflanzenschutz“ an Bedeutung gewonnen. Hierbei soll durch eine kombinierte Anwendung von biologischen, biotechnologischen, chemischen, physikalischen, anbautechnischen und pflanzenzüchterischen Verfahren der Einsatz chemischer Pflanzenschutzmittel auf das notwendige Maß beschränkt werden. Um die Effizienz des integrierten Pflanzenschutzes zu steigern, werden nichtchemische Pflanzenschutzverfahren weiterentwickelt, erprobt und in die Pflanzenschutzstrategien integriert (BMVEL; BMELV, 2008; Industrieverband Agrar, 2009).

Somit werden Antagonisten als Wirkorganismen biologischer Pflanzenschutzmittel intensiv erforscht und es sind in den letzten Jahren vermehrt biologische Pflanzenschutzmittel zugelassen worden. Dabei müssen biologische Pflanzenschutzmittel ähnlich wie chemische Pflanzenschutzmittel strenge Zulassungsauflagen erfüllen. Als wichtigstes Kriterium ist hierbei die Biosicherheit zu nennen, wobei von biologischen Wirkorganismen keine negativen Einflüsse auf Nützlinge, Umwelt, Mensch und Tier ausgehen dürfen (Fravel, 2005; Mathre et al., 1999). Die Tauglichkeit eines Organismus zum Einsatz als biologisches Pflanzenschutzmittel wird durch die Möglichkeit seiner massenhaften Produktion bestimmt. Für das Inverkehrbringen auf einen breiten Markt bedeutet das, dass die Antagonisten industriell vermehrbar sein müssen, zu stabilen Produkten formuliert werden können und eine hohe Lagerstabilität aufweisen müssen (Montesinos, 2003; Fravel, 2005). 
Ein sehr großes Potential zur biologischen Kontrolle phytopathogener Pilze geht von Antagonisten aufgrund ihrer diversen Wirkmechanismen aus. Dabei sind die wichtigsten Wirkmechanismen die Konkurrenz um Nährstoffe und Raum (Konkurrenz), die Ausscheidung antifungaler Verbindungen (Antibiosis), die Wachstumsförderung der Kulturpflanzen (Induzierte Resistenz) und die Parasitierung von Pathogenzellen (Parasitierung/Mykoparasitierung) (Whipps, 2001; Handelsman \& v. Stabb, 1996). In den letzten Jahren wurden weltweit eine Vielzahl biologischer Fungizide auf Basis von Bakterien und Pilzen zugelassen, mit denen mehr als 100 samen-, stroh-, und bodenbürtige phytopathogene Pilze bekämpft werden können (Fravel, 2005; Walters, 2009). Aufgrund der hohen Kosten, fehlender Wirkungssicherheit und geringer Ertragsund Qualitätseffekte konnten sich nur wenige biologische Pflanzenschutzmittel in den klassischen Ackerbaukulturen durchsetzen.

Ein Beispiel für ein in verschiedenen Ackerbaukulturen zur Nacherntebehandlung wirksam eingesetztes biologisches Pflanzenschutzmittel ist Contans ${ }^{\circledR}$ WG. Die Wirkung dieses Produktes basiert auf dem Mykoparasiten Coniothyrium minitans. Dieser Antagonist ist als wasserlösliches Granulat formuliert und kann in verschiedenen Kulturen zur Bekämpfung von Sclerotinia sclerotiorum eingesetzt werden. Contans ${ }^{\circledR}$ WG hat im Rapsanbau sehr hohe Wirkungserfolge bei der Bekämpfung der Weißstängeligkeit gezeigt (Prophyta GmbH; von Tiedemann et al., 2000). Zur erfolgreichen Bekämpfung wird Contans ${ }^{\circledR} \mathrm{WG}$ nach der Ernte auf die Rapsstoppeln bzw. vor der Rapsaussaat auf den Boden mittels Pflanzenschutzspritze appliziert und umgehend in 5-10 cm Bodentiefe eingearbeitet. C. minitans parasitiert anschließend die Überdauerungsformen (Sklerotien) von S. sclerotiorum, wodurch diese am Keimen und der Apothezienbildung gehindert werden. Darüber hinaus kann C. minitans über längere Zeit im Boden überdauern und zur nachhaltigen Bekämpfung von S. sclerotiorum beitragen (von Tiedemann et al., 2000; von Tiedemann et al., 2001; Gerlagh et al., 1999).

Mitte der 1990er Jahre konnte der Coelomycet Microsphaeropsis ochracea von abgestorbenen Apfelblättern aus kanadischen Apfelplantagen isoliert werden (Bernier et al., 1996). Nach ersten Untersuchungen zeigte $M$. ochracea ein hohes Potential zur biologischen Bekämpfung von Venturia inaequalis, dem Verusacher des Apfelschorfes. Durch Nacherntebehandlung von Apfelblättern mit M. ochracea, die mit V. inaequalis 
befallen waren, wurde die Inokulumproduktion reduziert. Dies führte zu einem verminderten Apfelschorfbefall im folgenden Jahr (Benyagoub et al., 1998; Carisse et al., 2000). Bei weiteren Untersuchungen in vitro und im Feld wurde M. ochracea als hoch wirksamer Antagonist von Botrytis squamosa, Rhizoctonia solani und Gibberella zeae nachgewiesen. Dabei besiedelt M. ochracea bevorzugt melanisierte Pilzstrukturen und penetriert die Pathogenzellen. Anschließend werden die Zellstruktur und die Zellorganellen durch die Ausscheidung von fungitoxischen Metaboliten aufgelöst, wodurch die Zellen abgetötet werden (Bassam et al., 2002; Carisse et al., 2006; Carisse et al., 2001; Bujold et al., 2001)

Nach ersten Untersuchungen der Prophyta GmbH, Malchow/Poel, Deutschland zur industriellen Vermehrung von M. ochracea wurde eine problemlose Massenproduktion dieses Antagonisten festgestellt. Darüber hinaus können Sporen von M. ochracea zu einem stabilen Produkt mit hoher Lagerstabilität formuliert werden (Eiben, Prophyta GmbH, persönliche Mitteilung).

Ziel dieser Arbeit war es, M. ochracea auf die Eignung als potentiellen Wirkorganismus eines biologischen Pflanzenschutzmittels hin zu überprüfen, welches im Getreide- und Rapsanbau eingesetzt werden kann. Deshalb wurde das antagonistische Potential von M. ochracea auf das stroh- und bodenbürtige Inokulum der pathogenen Pilze Gibberella zeae (Fusarium graminearum), Mycosphaerella graminicola (Septoria tritici), Pyrenophora tritici-repentis (Drechslera tritici-repentis), Leptosphaeria maculans (Phoma lingam) und Verticillium longisporum untersucht. Die Studien wurden in vitro, unter kontrollierten Bedingungen im Gewächshaus, in Strohabbauversuchen in unterschiedlichen Bodentiefen im Freiland und in Feldversuchen durchgeführt.

Aufgrund der zunehmenden Problematik des bodenbürtigen Pilzes V. longisporum im Rapsanbau und den dazu fehlenden Bekämpfungsstrategien wurde der Untersuchungsschwerpunkt dieser Arbeit auf die biologische Bekämpfung der Mikrosklerotien von $V$. longisporum durch $M$. ochracea gelegt.

In den folgenden Abschnitten werden die behandelten phytopathogenen Pilze zur Vereinheitlichung in der Nebenfruchtform bezeichnet, obwohl in den Feldversuchen und einigen Laboruntersuchungen auch die Wirkung von M. ochracea auf die Fruchtkörper (Hauptfruchtform) untersucht wurde. 


\section{Material und Methoden}

\subsection{Chemikalien}

Außer den aufgeführten Chemikalien wurden Chemikalien der Firmen Applichem, Carl Roth, Fluka GmbH und Merck KGaA mit dem Reinheitsgrad p.A. verwendet.

Agar-Agar

Agarose NEEO

Albi Gemüsesaft

Ameisensäure

Ampicillin Natriumsalz

Bacto-Trypton

Bacto-Hefeextrakt

CTAB (N-Cetyl-N,N,N-trimethyl-ammoniumbromid)

Czapek Dox Broth

dNTP-Mix (10 mM)

EDTA

Ethidiumbromid

Fluorescein

Glyzerin

Kaliumacetat

Kartoffel Glukose Agar (PDA)

Kartoffel Glukose Broth (PDB)

Lysozym

$\mathrm{MgCl}_{2}(25 \mathrm{mM})$

Na-EDTA

N-Lauroylsarcosin-Natriumsalz

Natriumacetat

PCR-Puffer (10 x)

Polyvinylpyrrolidon K30

Proteinase K

Polyethylenglycol 6000
Roth, Karlsruhe

Applichem, Darmstadt

Albi, Ulm

Applichem, Darmstadt

Applichem, Darmstadt

Difco Detroit, USA

Difco,Detroit, USA

Merck, Darmstadt

Duchefa,Haarlem, NL

Fermentas, St.Leon-Rot

Roth, Karlsruhe

Applichem, Darmstadt

Roche, Mannheim

Roth, Karlsruhe

Applichem Darmstadt

Roth, Karlsruhe

Roth, Karlsruhe

Applichem, Darmstadt

Fermentas, St.Leon-Rot

Merck, Darmstadt

Applichem, Darmstadt

Applichem, Darmstadt

Fermentas, St.Leon-Rot

Applichem, Darmstadt

Applichem, Darmstadt

Applichem, Darmstadt 
RNAseA

SDS-Lösung (10\%)

Sorbitol

Spermin-Trihydrochlorid

Streptomycinsulfat

SybrGreen

Taq-Polymerase (5U/ $\mu l)$

TAE $(10 \mathrm{x})$

TBE $(10 \mathrm{x})$

Tris-(hydroxymethyl) aminomethan

Tween 20
Applichem, Darmstadt

Applichem, Darmstadt

Applichem, Darmstadt

Applichem, Darmstadt

Duchefa, Haarlem, NL

Roche, Mannheim

Fermentas, St.Leon-Rot

Applichem Darmstadt

Applichem, Darmstadt

Roth, Karlsruhe

Scharlau, Barcelona, Spanien

\subsection{Nährmedien, Pufferlösungen und Trenngele}

Bei den beschriebenen Nährmedien handelt es sich um Festmedien und Flüssigmedien.

Die Medien wurden bei $121^{\circ} \mathrm{C}$ für 15 min autoklaviert und anschließend auf eine Temperatur von ca. $55^{\circ} \mathrm{C}$ im Wasserbad gekühlt. Bei Bedarf wurde den Medien ab einer Temperatur von $55^{\circ} \mathrm{C}$ Antibiotikum zugesetzt. Die Festmedien wurden anschließend in Polystyrolpetrischalen (9 cm Durchmesser, Fa. Sarstett) ausplattiert.

Folgende Medien wurden für die Anzucht von Pilzkulturen verwendet:

Potato Dextrose Agar (PDA)

PDA-Fertigmedium $39 \mathrm{~g}$

Streptomycinsulfat $200 \mathrm{mg}$

$\mathrm{H}_{2} \mathrm{O}$ ad $1000 \mathrm{ml}$

Hafermehlagar (OA)

Gemahlene Haferflocken $20 \mathrm{~g}$

Agar $15 \mathrm{~g}$

Streptomycinsulfat $200 \mathrm{mg}$

$\mathrm{H}_{2} \mathrm{O}$ ad $1000 \mathrm{ml}$ 
$\underline{8 \text { Gemüsesaft-Agar (V8A) }}$

Gemüsesaft (V8-Saft)

$200 \mathrm{ml}$

$\mathrm{CaCO}_{3}$

$3 \mathrm{~g}$

Agar

$18 \mathrm{~g}$

Streptomycinsulfat

$200 \mathrm{mg}$

$\mathrm{H}_{2} \mathrm{O}$

ad $1000 \mathrm{ml}$

Wasseragar (WA) 1,5\%

Agar

$15 \mathrm{~g}$

Streptomycinsulfat

$200 \mathrm{mg}$

$\mathrm{H}_{2} \mathrm{O}$

ad $1000 \mathrm{ml}$

Gewünschte pH-Werte wurden vor dem Autoklavieren mit NaOH bzw. $\mathrm{HCl}$ eingestellt, nach dem Autoklvieren bei Temperaturen von ca. $60^{\circ} \mathrm{C}$ erneut überprüft und bei Bedarf nachjustiert.

$\underline{\text { Roggenmehl-Quarzkies-Gemisch }}$

Grober Quarzkies $(\varnothing=1,5 \mathrm{~mm})$

Roggenmehl (Typ 997)

$\mathrm{H}_{2} \mathrm{O}$ $20 \mathrm{ml}$

$\underline{\text { Strohextrakt Agar (SEA) }}$

Gemahlenes Weizenstroh $(<2 \mathrm{~mm})$ $20 \mathrm{~g}$

Agar

$15 \mathrm{~g}$

$\mathrm{H}_{2} \mathrm{O}$ ad $1000 \mathrm{ml}$

$\underline{\text { Strohextrakt Medium (SEB) }}$

Gemahlenes Weizenstroh $(<2 \mathrm{~mm})$ $10 \mathrm{~g}$

$\mathrm{H}_{2} \mathrm{O}$ ad $500 \mathrm{ml}$

Potato Dextrose Broth (PDB)

PDB-Fertigmedium

$26,5 \mathrm{~g}$

$\mathrm{H}_{2} \mathrm{O}$ ad $1000 \mathrm{ml}$

Czapek Dox Broth (CZDB)

CZDB-Fertigmedium $33,4 \mathrm{~g}$

$\mathrm{H}_{2} \mathrm{O}$ ad $1000 \mathrm{ml}$ 
Malz-Hefeextrakt Agar (MYA)

Malzextrakt

$10 \mathrm{~g}$

Hefeextrakt

$4 \mathrm{~g}$

Glukose

$4 \mathrm{~g}$

Streptomyzinsulfat

$200 \mathrm{mg}$

Agar

$15 \mathrm{~g}$

$\mathrm{H}_{2} \mathrm{O}$

ad $1000 \mathrm{ml}$

Folgende Medien und Pufferlösungen wurden für die Anzucht von Bakterien, die Ligation, die Transformation und die Plasmidpräparation verwendet. Die Pufferlösungen und Nährmedien wurden nach vollständiger Lösung der Chemikalien mit $\mathrm{NaOH}$ bzw. $\mathrm{HCl}$ auf den entsprechenden $\mathrm{pH}-$ Wert eingestellt:

Luria-Bertani Flüssig- Festmedium (LB-Medium), pH 7,0

Bacto-Trypton

$10 \mathrm{~g}$

Bacto-Hefeextrakt

$\mathrm{NaCl}$

$10 \mathrm{~g}$

Ampicillin $(100 \mu \mathrm{g} / \mathrm{ml})$

$1 \mathrm{ml}$

$\mathrm{H}_{2} \mathrm{O}$ bidest.

ad $1000 \mathrm{ml}$

Um das LB-Festmedium herzustellen wurde vor dem Autokolavieren 15 g (1,5\%) Agar hinzugegeben.

\section{GLC-Puffer, $\mathrm{pH} 8,0$}

Glukose

$0,99 \mathrm{~g}$

EDTA

Tris

$\mathrm{H}_{2} \mathrm{O}$ bidest.

ad $100 \mathrm{ml}$

Kurz vor Gebrauch Lysozym auf eine Endkonzentration von 0,5 mg/ml zugeben

$\underline{\text { HS-Puffer }}$

Kaliumacetat

$29,4 \mathrm{~g}$

Ameisensäure (98-100\%)

$3,8 \mathrm{ml}$

$\mathrm{H}_{2} \mathrm{O}$ bidest.

ad $100 \mathrm{ml}$ 
$\underline{\text { LYZ-Puffer }}$

$2 \mathrm{M} \mathrm{NaOH}$

$1 \mathrm{ml}$

10\% SDS-Lösung

$1 \mathrm{ml}$

$\mathrm{H}_{2} \mathrm{O}$ bidest

ad $10 \mathrm{ml}$

SOC-Medium, pH 7,0

Bacto Trypton

$20 \mathrm{~g}$

Bacto Hefe Extrakt

$5 \mathrm{~g}$

$\mathrm{NaCl}$

$0,5 \mathrm{~g}$

Die Komponenten wurden in $\mathrm{H}_{2} \mathrm{O}$ gelöst, $10 \mathrm{ml} 250 \mathrm{mM}$ KCl-Lösung addiert, die Lösung mit $5 \mathrm{~N} \mathrm{NaOH-Lösung} \mathrm{auf} \mathrm{pH} 7$ eingestellt und mit $\mathrm{H}_{2} \mathrm{O}$ auf $1000 \mathrm{ml}$ aufgefüllt. Nach dem Autoklavieren wurden $5 \mathrm{ml} 2 \mathrm{M} \mathrm{MgCl}_{2}$-Lösung addiert. Nach dem Erkalten wurde durch Zugabe von Glukoselösung eine Endkonzentration von 20 mM eingestellt.

Die folgenden Pufferlösungen wurden zur CTAB DNA-Extraktion und zur DNA Aufreinigung verwendet. Mit den Trenngelen wurden die DNA-Extrakte und PCR-Produkte unter UV-Licht visualisiert und mit Hilfe einer Kamera und der Geldokumentationssoftware Multi-Analyst (Gel Doc System Biorad, München) dokumentiert. Die Pufferlösungen wurden nach vollständiger Lösung der Chemikalien mit $\mathrm{NaOH}$ bzw. $\mathrm{HCl}$ auf den entsprechenden $\mathrm{pH}$-Wert eingestellt und mit $\mathrm{H}_{2} \mathrm{O}$ bidest auf das Endvolumen aufgefüllt.

CTAB-Puffer, pH 8,0

Na-EDTA

$7,4 \mathrm{~g}$

Sorbitol $23 \mathrm{~g}$

N- Lauroylsarcosin-Natriumsalz $10 \mathrm{~g}$

CTAB $8 \mathrm{~g}$

$\mathrm{NaCl}$ $47 \mathrm{~g}$

Polyvinylpyrrolidon $10 \mathrm{~g}$

1 M Tris $10 \mathrm{ml}$

$\mathrm{H}_{2} \mathrm{O}$ bidest ad $1000 \mathrm{ml}$ 
$10 \times$ Tris-EDTA Puffer $(10 \times \mathrm{TE})$ :

1 M Tris

$50 \mathrm{ml}$

0,5 M EDTA

$10 \mathrm{ml}$

$\mathrm{H}_{2} \mathrm{O}$ bidest

ad $500 \mathrm{ml}$

Polyethylenglycol 6000 (PEG)

$300 \mathrm{mg} / \mathrm{ml} \mathrm{H}_{2} \mathrm{O}$ bidest

Proteinase K

$20 \mathrm{mg} / \mathrm{ml} \mathrm{H}_{2} \mathrm{O}$ bidest, Lagerung bei $-20^{\circ} \mathrm{C}$

RNAseA $10 \mathrm{mg} / \mathrm{ml}$ in $10 \mathrm{mM}$ Tris, $15 \mathrm{mM} \mathrm{NaCl}$ lösen, Lagerung bei $-20^{\circ} \mathrm{C}$

Sperminhydrochlorid

$25 \mathrm{mg} / \mathrm{ml} \mathrm{H}_{2} \mathrm{O}$ bidest, Lagerung bei $-20^{\circ} \mathrm{C}$

Spermin-Puffer

0,3 M Na Acetat

$125 \mathrm{ml}$

$1 \mathrm{M} \mathrm{MgCl}_{2}$

$1,25 \mathrm{ml}$

EtOH 96\%

ad $500 \mathrm{ml}$

TBE Agarose Trenngel (1\%ig, 1,2\%ig)

Agarose

$1 \mathrm{~g}, 1,2 \mathrm{~g}$

Ethidiumbromid

$3 \mu \mathrm{l}$

0,5 x TBE-Puffer

$100 \mathrm{ml}$

TAE Agarose Trenngel (1,2\%)

Agarose

$1,2 \mathrm{~g}$

$1 \mathrm{x}$ TAE-Puffer

$100 \mathrm{ml}$ 


\subsection{Vermehrung und Erhaltung von Pilzmaterial}

Für die in vitro Untersuchungen, die Gewächshausversuche und die Primer Spezifitätstestungen wurden die in Tab. 1 dargestellten Pilzisolate aus der Stammsammlung der Abteilung Allgemeine Pflanzenpathologie und Pflanzenschutz des Departements für Nutzpflanzenwissenschaften der Universität Göttingen verwendet.

Tab. 1: Für in vitro Untersuchungen, Gewächshausversuche und Primer Spezifitätstestungen verwendete Pilze / Isolate.

\begin{tabular}{lccccc}
\hline \multicolumn{1}{c}{ Art } & Stamm & Land & Jahr & Wirt & Anzuchtmedium \\
\hline M. ochracea & P130 A & CDN & 1996 & Apfelblätter & OA \\
V. longisporum & Vl 43 & D & 1990 & Winterraps & PDA / PDB \\
V. dahliae & Vd 73 & D & 1993 & Lein & PDA / PDB \\
P. lingam & IBCN 88 & CDN & 1989 & Winterraps & V8 / OA \\
D. tritici-repentis & NRW 2 & D & 1993 & Winterweizen & PDA / V8 \\
S. tritici & S4.20 & D & 1998 & Winterweizen & MYA \\
F. graminearum & Fg. 12 & D & 2008 & Winterweizen & PDA \\
C. minitans & -- & -- & 2003 & -- & OA \\
\hline
\end{tabular}

\subsubsection{Microsphaeropsis ochracea}

Zur Untersuchung des mykoparasitischen Potentials von $M$. ochracea wurde das Isolat P130A verwendet. Dieses Isolat zeigte bereits in früheren Untersuchungen ein deutlich höheres mykoparasitisches Potential im Vergleich zu anderen Isolaten von M. ochracea (Carisse \& Bernier, 2002a) und wurde für die Produktentwicklung (M. ochracea WG) von der Prophyta GmbH genutzt. Als Erhaltungskultur wurde das Isolat in Schrägröhrchen mit Hafermehlagar unter dickflüssigem Parafinöl bei $4^{\circ} \mathrm{C}$ gelagert. M. ochracea wurde zur Anzucht aus den Schrägröhrchen auf OA überimpft und bei $20^{\circ} \mathrm{C}, 16 \mathrm{~h} \mathrm{Licht}$ (L 18W/30, Fa. Osram) und 8 h Dunkelheit inkubiert. Nach 3 Wochen wurden die Pyknidien durch Abstreifen mit einem sterilen Objektträger entleert und die Platte mit $5 \mathrm{ml}$ sterilem $\mathrm{H}_{2} \mathrm{O}$ abgeschwemmt. Die Sporendichte wurde mit Hilfe einer ThomaZählkammer bestimmt, mit sterilem $\mathrm{H}_{2} \mathrm{O}$ auf eine Sporendichte von 1 x $10^{9}$ Sporen $/ \mathrm{ml}$ eingestellt, in $1,5 \mathrm{ml}$ Eppendorfgefäße portioniert und bei $-20^{\circ} \mathrm{C}$ gelagert. Eine kontinuierliche Vermehrung von $M$. ochracea für die in vitro Untersuchungen und die Gewächshausversuche erfolgte aus den tiefgefrorenen Aliquoten. Hierfür wurden $200 \mu \mathrm{l}$ 
der Sporensuspension auf OA gegeben und mit einem sterilen Drigalskispatel gleichmäßig ausgestrichen. Die Inkubation und die Herstellung der M. ochracea Sporensuspension erfolgten wie oben beschrieben.

\subsubsection{Verticillium spp.}

Für die in vitro Untersuchungen und die Gewächshausversuche wurde das Isolat Vl 43 von V. longisporum und das Isolat Vd 73 von V. dahliae verwendet. Beide Isolate haben sich bereits in früheren Untersuchungen für in vitro- und Gewächshausversuche als geeignet erwiesen (Eynck et al., 2007). Zur Erhaltung wurden die Isolate bei $-80^{\circ} \mathrm{C}$ in einer Glycerin Stocklösung mit einer Sporendichte von 2 × $10^{3}$ Sporen/ml gelagert. Die Vermehrung von Verticillium spp. erfolgte auf PDA und in PDB Schüttelkultur. Zum Beimpfen von PDA Nährmedien wurde $200 \mu$ l Glycerinstocklösung auf PDA gegeben und mit einem Drigalskispatel gleichmäßig verteilt. Die Platten wurden frühestens nach drei Wochen Inkubation bei $20^{\circ} \mathrm{C}$ in Dunkelheit für weitere Versuche verwendet. Zur Vermehrung von Verticillium spp. in Schüttelkultur wurden $500 \mathrm{ml}$ autoklaviertes PDB mit $500 \mu$ l Glycerinstocklösung beimpft und für 14 Tage bei $23^{\circ} \mathrm{C}$ auf einem Schüttelinkubator (100 rpm) im Dunkeln inkubiert.

\subsubsection{Fusarium graminearum}

Für die in vitro Untersuchungen wurde das Isolat Fg 12 von F. graminearum verwendet. Dieses Isolat erwies sich als geeignet für die Perithezienproduktion (Gibberella zeae) auf Haferkörnern. Fg 12 wurde aus einem Lyophilisat auf PDA angezogen, anschließend auf SEA überimpft und nach ausreichender Myzelbildung bei $4^{\circ} \mathrm{C}$ als Erhaltungskultur gelagert. Zur Vermehrung von Fg 12 in Schüttelkultur wurden $500 \mathrm{ml}$ autoklaviertes SEB mit 2-3 mit Fg 12 bewachsenen SEA Plugs beimpft und bis zu einer ausreichenden Konidienbildung ( $>1 \times 10^{6}$ Sporen $/ \mathrm{ml}$ ) bei $20^{\circ} \mathrm{C}$ auf einem Schüttelinkubator inkubiert. 


\subsection{Inokulumproduktion}

\subsubsection{M. ochracea WG}

Das Produkt M. ochracea WG mit dem Wirkorganismus M. ochracea (Stamm P130A) wurde von der Prophyta GmbH für Gewächshaus-, Litterbag- und Feldversuche zur Verfügung gestellt. M. ochracea wurde mit Hilfe der „solid state“ Technologie vermehrt und die gewonnenen Sporen an Glukose formuliert und getrocknet (Frau Eiben, Prophyta GmbH, persönliche Mitteilung). Das formulierte Endprodukt M. ochracea WG hatte einen Gehalt von größer 2,5 x $10^{9}$ keimfähiger Sporen von M. ochracea pro Gramm Produkt. Das Produkt war vollständig wassersuspensierbar und konnte für mindestens 6 Monaten bei einer Temperatur von $4^{\circ} \mathrm{C}$ ohne Wirkungsverluste gelagert werden.

\subsubsection{Mikrosklerotienproduktion von Verticillium spp. auf sterilen Rapsstängeln}

Zur Mikrosklerotienproduktion auf Rapsstängeln wurden gesunde Rapsstängel halbiert und in ca. 3 cm große Stücke geschnitten. Die Rapsstängelstücke wurden zweimal im Abstand von $24 \mathrm{~h}$ für 15 min bei $121^{\circ} \mathrm{C}$ autoklaviert und durch Tauchen in eine Vl 43 Sporensuspension mit einer Sporendichte von 1 x $10^{6}$ Sporen/ml beimpft. Die Inkubation erfolgte für 3 Wochen auf Wasseragar bei $20^{\circ} \mathrm{C}$ im Dunkeln. Anschließend wurden die mit Mikrosklerotien bewachsenen Rapsstängelstücke unter der Impfbank getrocknet und nach dem Mikrosklerotiendeckungsgrad (Tab.2) sortiert.

Tab. 2: Bonitur der Rapsstängelstücke nach Mikrosklerotiendeckungsgrad.

\begin{tabular}{cc}
\hline Boniturstufe & Mikrosklerotiendeckungsgrad (\%) \\
\hline 0 & $10-40 \%$ \\
1 & $40-70 \%$ \\
2 & $70-100 \%$ \\
\hline
\end{tabular}




\subsubsection{Mikrosklerotienproduktion von Verticillium spp. im Sandgemisch}

Die sterile Anzucht von Mikrosklerotien für in vitro Experimente und Gewächshausversuche erfolgte in Anlehnung an Heppner, (1995) und wurde weiter optimiert. Nach dem Ansetzen des Roggenmehl-Quarzkies-Gemisches (S.7) wurde dieses zweimal im Abstand von $24 \mathrm{~h}$ für 15 min bei $121^{\circ} \mathrm{C}$ autoklaviert. Anschließend wurde das Gemisch zu je $40 \mathrm{~g}$ in $50 \mathrm{ml}$ Falkonröhrchen portioniert, oder es wurden Pilzanzuchttüten $\left(\mathrm{SACO}_{2}\right.$, Eke-Nazareth, Belgien) mit $300 \mathrm{~g}$ Roggenmehl-Quarzkies-Gemisch befüllt. Die Deckel der Falkonröhrchen wurden zum Gasaustausch mit Löchern versehen und mit Alufolie abgedeckt. Das Roggenmehl-Quarzkies-Gemisch wurde erneut autoklaviert und nach einer Abkühlphase von mindestens $12 \mathrm{~h}$ mit ca. $100 \mu \mathrm{l}$ Sporensuspension von Verticillium spp. (>1 x $10^{6}$ Sporen $/ \mathrm{ml}$ ) pro g RoggenmehlQuarzkies-Gemisch beimpft. Anschließend wurde das Gemisch erneut gut durchmischt und für 3 Wochen bei Raumtemperatur im Dunkeln inkubiert. Je nach Versuchsansatz wurden das mit Mikrosklerotien durchwachsene Roggenmehl-Quarzkies-Gemisch steril (in vitro Versuche) unter der Impfbank, oder unsteril (Gewächshausversuche) bei Raumtemperatur getrocknet. Zum Trennen der Mikrosklerotien von Roggenmehl und Quarzkies wurde das getrocknete Gemisch mit einem Siebsatz mit einer Maschenweite von 400 und $200 \mu \mathrm{m}$ gesiebt. Die Lagerung der Mikrosklerotien erfolgte in Polystyrolpetrischalen mit Filterpapierunterlage bei $4^{\circ} \mathrm{C}$. Für die in vitro Untersuchungen wurden Mikrosklerotien der Größenfraktion 200-400 $\mu \mathrm{m}$ verwendet. Für die Gewächshausversuche wurden alle Größenfraktionen $<400 \mu \mathrm{m}$ verwendet.

\subsubsection{Perithezienproduktion von F. graminearum auf Haferkörnern}

Zur Perithezienproduktion wurden gereinigte Haferkörner für $12 \mathrm{~h}$ in Wasser gequollen, das überschüssige Wasser abgegossen und die Haferkörner zweimal im Abstand von 24 h für je 15 min bei $121^{\circ} \mathrm{C}$ autoklaviert. Anschließend wurden Pilzanzuchttüten mit einer 1-2 cm hohen Schicht Haferkörner befüllt und erneut für $15 \mathrm{~min}$ bei $121^{\circ} \mathrm{C}$ autoklaviert. Nach einer Abkühlungsphase von mindestens 12 h erfolgte die Inokulation der Haferkörner mit $50 \mathrm{ml}$ einer Fg 12 Konidiensuspension ( $>1 \times 10^{6}$ Sporen/ml) pro Pilzanzuchttüte. Während der 3 wöchigen Inkubation bei Raumtemperatur wurden die Haferkörner jeden zweiten Tag durchmischt um eine starke Luftmyzelbildung zu unterbinden. Anschließend wurden die mit Fg 12 bewachsene Haferkörner unter der Impfbank getrocknet. Zur Perithezienproduktion wurden je 30 bis 40 getrocknete und mit 
Fg 12 bewachsene Haferkörner auf Wasseragar ausgelegt und bei $20^{\circ} \mathrm{C}$ und Dauerlicht (L 18W/30, Fa. Osram) für 4-7 Tage inkubiert. Nach ausreichender Perithezienbildung und beginnender Askosporenausschleuderung wurden die Haferkörner geerntet und erneut unter der Impfbank getrocknet. Die Haferkörner wurden nach Peritheziendeckungsgrad sortiert (Tab. 3) und bei $4^{\circ} \mathrm{C}$ gelagert.

Tab. 3: Einteilung der Haferkörner nach Peritheziendeckungsgrad.

\begin{tabular}{cc}
\hline Boniturstufe & Peritheziendeckungsgrad \\
\hline 0 & Keine Perithezien $(<10 \%)$ \\
1 & Wenig Perithezien $(10-50 \%)$ \\
2 & Viele Perithezien $(50-100 \%)$ \\
\hline
\end{tabular}

\subsection{Visuelle Erfassung des Rapspflanzenbefalls mit V. longisporum}

\subsubsection{Befallserfassung im Freiland}

Eine visuelle Erfassung des Befalls der Rapspflanzen mit $V$. longisporum erfolgte nach der Ernte (BBCH 97) an den abgereiften Rapsstoppeln. Pro Versuchsparzelle wurden 50 Rapsstoppeln zufallsverteilt aus der Kernparzelle gezogen, die Wurzeln gereinigt und bis zur visuellen Bonitur trocken gelagert. Als alleiniges Kriterium des Befalls der Rapsstoppeln mit $V$. longisporum wurde der Besatz mit Mikrosklerotien herangezogen. Das Vorhandensein und die Besatzdichte mit Mikrosklerotien von V.longisporum (Ø 30-50 $\mu \mathrm{m})$ wurde mit Hilfe eines Stereomikroskops nach einer vierstufigen Boniturskala untersucht (Tab. 4) (Eynck, 2007). 
Tab. 4: Boniturskala zur Ermittlung des Befallswertes von V. longisporum anhand der Mikrosklerotiendichte am Rapsstängel, im Stängelmark und in der Wurzel in den Feldversuchen (Stoppelentnahme nach der Ernte; n = 50; Eynck, 2007).

\begin{tabular}{|c|c|}
\hline Befallswert & Symptome \\
\hline 1 & Kein Befall; keine Mikrosklerotien \\
\hline 2 & $\begin{array}{c}\text { Schwacher Befall; wenige Mikrosklerotien unter der Epidermis, im } \\
\text { Mark und in der Wurzel }\end{array}$ \\
\hline 3 & $\begin{array}{c}\text { Mittlerer Befall; viele Mikrosklerotien unter der Epidermis im Mark } \\
\text { und in der Wurzel }\end{array}$ \\
\hline 4 & $\begin{array}{l}\text { Starker Befall; Aufplatzen der Epidermis mit sehr starkem } \\
\text { Mikrosklerotienbesatz, starker Mikrosklerotienbesatz im Mark, } \\
\text { starker Mikrosklerotienbesatz in der Wurzel }\end{array}$ \\
\hline
\end{tabular}

Neben dem äußeren Befall der Rapsstängel, wurde der Mikrosklerotienbesatz im Stängelmark und in der Wurzel erfasst. Hierzu wurden die ca. 30-40 cm langen Rapsstoppeln der Länge nach aufgeschnitten und der Mikrosklerotienbesatz unter dem Stereomikoskop bonitiert. Der V. longisporum Befallswert (BW) von Stängel, Stängelmark und Wurzel wurde nach folgender Formel berechnet:

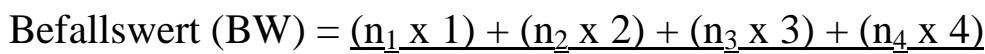

$\mathrm{n}_{\mathrm{x}}=$ Anzahl Pflanzen des jeweiligen Befallswertes

1-4 = Befallswert

$\mathrm{N}=$ Anzahl bonitierter Rapsstängel

Zur Berechnung des mittleren Befallswertes der jeweiligen Versuchsparzellen wurde der Mittelwert aus den Befallswerten der drei Pflanzenteile (Stängel, Stängelmark, Wurzel) gebildet.

Mittlerer Befallswert $=\underline{\text { BW Stängel }+ \text { BW Stängelmark }+ \text { BW Wurzel }}$

3

\subsubsection{Befallserfassung im Gewächshaus}

Für die visuelle Bonitur des Befalls mit V. longisprum an Gewächshauspflanzen wurde ein Boniturschlüssel in Anlehnung an Zeise (1992) verwendet (Tab. 5). Dieser wurde 
speziell für die visuelle Bonitur des Verticillium-Befalls an jungen Rapspflanzen entwickelt. Für die Gewächshausversuche wurde ausschließlich die Rapsvarietät „rapid cycling rapeseed“ als Modellpflanze verwendet. Da dieser seinen vollständigen Entwicklungszyklus innerhalb kurzer Zeit durchläuft und es bei ausreichender Nährstoffversorgung zu keinem frühzeitigen Blattverlust kommt, erwies sich dieser Boniturschlüssel auch in älteren Entwicklungsstadien (BBCH 51-75) zur Erfassung der Befallsstärke als geeignet. Es wurde versucht ausschließlich Blätter mit eindeutigen Verticillium-Blattsymptomen (halbseitige Vergilbung, Schwarzadrigkeit) für die Bonitur zu verwenden. Es konnte eine Bonitur unspezifischer Blattvergilbungen, vor allem zu späteren Boniturterminen nicht ausgeschlossen werden, was in manchen Versuchsansätzen zu erhöhten Befallswerten in den Wasserkontrollen führte.

Tab. 5: Boniturskala zur Ermittlung des Befallswertes von V. longisporum anhand von Blattsymptomen an Rapspflanzen im Gewächshaus (mod. nach Zeise, 1992)

\begin{tabular}{cc}
\hline BW & Symptombeschreibung \\
\hline 1 & Keine Symptome \\
2 & Leichte Symptome am ältesten Blatt (Vergilbung, schwarze Adern) \\
3 & Leichte Symptome auch an den nächst jüngeren Blättern \\
4 & Etwa 50\% der Blätter mit Symptomen \\
5 & Mehr als 50\% der Blätter mit Symptomen \\
6 & Bis zu 50\% der Blätter sind abgestorben \\
7 & Mehr als 50\% der Blätter sind abgestorben \\
8 & Die Pflanze ist abgestorben \\
\hline
\end{tabular}

Der Befallswert (BW) wurde nach folgender Formel berechnet:

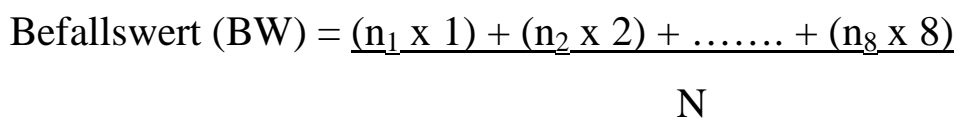

$\mathrm{n}_{\mathrm{x}}$ : Anzahl Pflanzen mit dem jeweiligen Befallswert

1-8: Befallswert

$\mathrm{N}$ : Anzahl der insgesamt bonitierten Pflanzen 


\subsection{Visuelle Erfassung des Rapspflanzenbefalls mit Phoma lingam}

\subsubsection{Herbstbonitur}

Die Erfassung des Wurzelhalsbefalls der Rapspflanzen mit P. lingam wurde in Abhängigkeit von der Befallssituation im Herbst durchgeführt. Es wurden 40-60 Pflanzen (BBCH 16-18) zufallsverteilt aus dem Kernbereich jeder Versuchsparzelle gezogen, die Wurzeln gereinigt und bis zur Bonitur bei $7^{\circ} \mathrm{C}$ gelagert. Zur Bestimmung des Wurzelhalsbefalls an jungen Rapspflanzen wurden diese mit Hilfe eines Stereomikroskops auf oberflächliche Verbräunungen, Verkorkungen und Pyknidien untersucht die auf einen Befall mit P. lingam zurückzuführen waren. Dabei wurde nur die Befallshäufigkeit (prozentualer Anteil befallener Pflanzen in der Stichprobe) in den einzelnen Versuchsparzellen erfasst.

\subsubsection{Frühsommerbonitur}

Eine visuelle Bonitur des Befalls der Rapspflanzen mit P. lingam im Frühsommer wurde zu beginnender Reife (BBCH 75-80) durchgeführt. Pro Versuchsparzelle wurden 50 Pflanzen zufallsverteilt aus der Kernparzelle gezogen, die Schotenpakete in ca. 65 cm Stängelhöhe abgeschnitten, die Wurzeln von der Erde gereinigt und die Pflanzen bis zur Bonitur bei $7^{\circ} \mathrm{C}$ gelagert. Die Befallsbeurteilung an Wurzelhals und Stängel mit $P$. lingam orientierte sich an einer neunstufigen Boniturskala (1-9) die von Krüger (1982) entwickelt wurde (Tab. 6). 
Tab. 6: Boniturskala zur Ermittlung des Befallswertes von P. lingam an Rapspflanzen zu beginnender Reife in den Feldversuchen (nach Krüger, 1982).

\begin{tabular}{|c|c|c|}
\hline \multirow{2}{*}{ Befallswert } & \multicolumn{2}{|c|}{ Symptome } \\
\hline & Wurzelhals & Stängel \\
\hline 1 & Kein Befall & Kein Befall \\
\hline 2 & Kleine Flecken an der Oberfläche & Kleine Flecken an der Oberfläche \\
\hline 3 & $\begin{array}{c}\text { Kleine Flecken mit geringer } \\
\text { Verkorkung und / oder } \\
\text { Verbräunung im } \\
\text { Wurzelhals }\end{array}$ & $\begin{array}{c}\text { Größere Flecken an der Oberfläche } \\
\text { mit geringer Verkorkung }\end{array}$ \\
\hline 4 & Zwischenstufe & Zwischenstufe \\
\hline 5 & $\begin{array}{l}\text { Umfassende oberflächliche } \\
\text { Verkorkung (bis } 50 \% \text { des } \\
\text { Wurzelhals befallen) }\end{array}$ & Tiefere Befallsstellen am Stängel \\
\hline 6 & Zwischenstufe & Zwischenstufe \\
\hline 7 & $\begin{array}{c}\text { Über 50\% des Wurzelhals tief } \\
\text { verkorkt }\end{array}$ & Tiefe Befallsstellen mit Pyknidien \\
\hline 8 & Zwischenstufe & Zwischenstufe \\
\hline 9 & $\begin{array}{l}\text { Pflanze abgestorben, } \\
\text { starkeVerkorkung }\end{array}$ & $\begin{array}{l}\text { Pflanze abgestorben, tiefe } \\
\text { Befallsstellen }\end{array}$ \\
\hline
\end{tabular}

Der Befallswert von $P$. lingam an Wurzelhals und Stängel errechnete sich nach folgender Formel:

Befallswert $(\mathrm{BW})=\underline{\mathrm{n}}_{1} \underline{\times 1)}+\left(\underline{\mathrm{n}}_{2} \underline{\times} 2\right)+\ldots .+\left(\underline{\mathrm{n}}_{\underline{9}} \underline{\times 9}\right)$

$\mathrm{n}_{\mathrm{x}}$ : Anzahl Pflanzen mit jeweiligem Befallswert

1-9: Befallswerte

$\mathrm{N}$ : Anzahl insgesamt bonitierter Pflanzen 


\subsection{Visuelle Bonitur der Krankheiten an Winterweizen}

Visuelle Krankheitsbonituren wurden im Winterweizenmonokulturversuch im Frühsommer 2008 und 2009 durchgeführt. In beiden Jahren erfolgte eine zweimalige Bonitur zwischen BBCH 39 und BBCH 80. Es wurden aus jeder Versuchsparzelle 40 Pflanzen zufallsverteilt aus der Kernparzelle entnommen und der prozentuale Anteil nekrotisierter Blattfläche durch die Blattpathogene D. tritici-repentis (DTR) und S. tritici auf allen vitalen Blattetagen differenziert bonitiert. Zur visuellen Bonitur der prozentualen nekrotisierten Blattfläche wurden die Boniturhilfen der EPPO-Richtlinie verwendet (Bartels et al., 2000). Da für P. tritici-repentis dem Verursacher von DTR Blattflecken keine Boniturhilfe existiert, wurde die Bonituhilfe für Blumeria graminis an Gerste verwendet, da sich diese als geeignet erwies. Die Befallsstärke (BS) (prozentual nekrotisierte Blattfläche) von S. tritici und DTR wurde nach folgender Formel berechnet:

Befallsstärke in \% (BS) $=\underline{\Sigma(\% \text { befallene Blattfläch pro Blatt und Blattetage })}$

Anzahl bonitierte Blätter pro Blattetage

\subsection{PCR-Untersuchungen (Polymerase Kettenreaktion)}

Zur Bestimmung der Befallsstärke mit $V$. longisporum wurde neben der visuellen Befallserfassung, die DNA von V. longisporum im Pflanzengewebe durch Real-time PCR quantifiziert. Diese Untersuchungsmethode wurde bei den meisten Gewächshausversuchen und im Jahr 2009 bei dem Winterrapsmonokulturversuch angewendet.

\subsubsection{Probenahme und Probenaufarbeitung}

Zur Probenahme im Gewächshaus wurde der untere Stängelabschnitt $(10 \mathrm{~cm})$ der Rapspflanzen beprobt, 10-18 Pflanzen je nach Versuchsansatz zu einer Probe zusammengefasst und das Pflanzengewebe für $72 \mathrm{~h}$ gefriergetrocknet (Gefriertrocknung, Fa. Christ). Anschließend wurde das Pflanzengewebe mit einer Schwingmühle (MM 200, Fa. Retsch) in 25 ml Stahlbechern mit Stahlkugeln für 90 sec. bei $20 \mathrm{~Hz}$ fein vermahlen.

Zur Beprobung der Feldversuche wurden je 15 Rapsstoppeln nach der Ernte zufallsverteilt aus dem Kernbereich jeder Versuchsparzelle gezogen und der Hypokotylbereich $(1 \mathrm{~cm})$ beprobt. Das Probenmaterial wurde für 72 h gefriergetrocknet und im Institut für Pflanzenbau und Pflanzenzüchtung in einer Schlagrotormühle (Fa. Retsch) bei einer 
Siebgröße von $4 \mathrm{~mm}$ vorzerkleinert. Anschließend wurden 1,5 g des vorzerkleinerten Materials in einer Schwingmühle fein vermahlen (s.o.).

Zur Beprobung der Litterbagversuche wurden die Litterbags geborgen und luftgetrocknet. Grobe Erdanhaftungen wurden von dem Rapsstroh entfernt, das Probenmaterial in Polyethylenbeutel transferiert, für $72 \mathrm{~h}$ gefriergetrocknet und die Erdreste vorsichtig abgesiebt (2 mm Sieb). Anschließend wurden 1,5 g des Probenmaterials in einer Schwingmühle fein vermahlen (s.o.).

Zur Beprobung der Quarkschalentests wurden die mit Rapsstroh befüllten Netzsäcke geborgen, in Polyethylenbeutel transferiert und für 72 h gefriergetrocknet. Anschließend wurde das Probenmaterial vorsichtig gesiebt (2 mm Sieb), um fein anhaftende Bodenpartikel zu entfernen und mit Hilfe einer Schwingmühle fein vermahlen (s.o.).

\subsubsection{DNA Extraktion}

Die Extraktion von DNA aus Pflanzengewebe der Feld- und Gewächshausversuche und aus Pilzmyzel erfolgte mit Hilfe des DNeasy Plant Mini Kits der Firma Qiagen, Hilden. Zur Extraktion wurden $30 \mathrm{mg}$ gefriergetrocknetes fein vermahlenes Probenenmaterial verwendet. Nach der Extraktion wurden $5 \mu$ DNA-Probe auf ein 1\%iges Agarosegel aufgetragen, und elektrophoretisch aufgetrennt, um die Qualität und Quantität der extrahierten DNA zu überprüfen.

Zur Verbesserung der DNA-Ausbeute wurde für die DNA-Extraktion aus Probenmaterial der Litterbagversuche und der Quarkschalentests die CTAB-Extraktionsmethode in Anlehnung an Brandfaß \& Karlovsky (2006) verwendet. Es wurden 100 mg Probenmaterial in $2 \mathrm{ml}$ Eppendorfgefäße eingewogen und mit 1 ml CTAB-Puffer $+2 \mu \mathrm{l}$ Mercaptoethanol $+1 \mu$ l Proteinase K zügig vermischt. Die Proben wurden für $5 \mathrm{~s}$ im Ultraschallbad behandelt und für $10 \mathrm{~min}$. bei $42^{\circ} \mathrm{C}$ und für $10 \mathrm{~min}$ bei $65^{\circ} \mathrm{C}$ inkubiert. Nach der Zugabe von $800 \mu$ l Chloroform-Isoamylalkohol (24:1) wurden die Proben geschüttelt und für 10 min auf Eis inkubiert. Nach einem Zentrifugationsschritt für 10 min bei 8000 RPM, wurde die obere wässrige Phase in 1,5 ml Eppendorfgefäße überführt, mit $210 \mu \mathrm{l}$ PEG (30\%) vermischt und für 20 min bei Raumtemperatur inkubiert. Im Anschluss wurden die Proben für 15 min bei max. RPM zentrifugiert, der Überstand verworfen, das DNA-Pellet mit 70\%igem ETOH gewaschen und getrocknet. Die DNA wurde mit $150 \mu \mathrm{l} 1 \mathrm{x}$ TE $+3 \mu \mathrm{l}$ RNAseA $(10 \mathrm{mg} / \mathrm{ml})$ versetzt, über Nacht bei $4^{\circ} \mathrm{C}$ resuspendiert und am nächsten Tag für $2 \mathrm{~h}$ bei $40^{\circ} \mathrm{C}$ im Wasserbad inkubiert. Bei 
Bedarf wurde die DNA nochmals aufgereinigt (vgl. 2.8.3). Anschließend wurden $5 \mu \mathrm{l}$ Probe auf ein 1\%iges Agarosegel aufgetragen, elektrophoretisch aufgetrennt und die DNA- Konzentration bestimmt.

\subsubsection{Spermin-Fällung von DNA}

Um die DNA von Inhibitoren zu reinigen die die PCR Amplifikation negativ beeinflussen, wurde die extrahierte DNA gereinigt. $100 \mu \mathrm{l}$ DNA wurden mit $2 \mu \mathrm{l}$ Spermin-Hypochlorid vermischt, für 15 min bei Raumtemperatur und 60 min auf Eis inkubiert und für 10 min bei 14000 RPM zentrifugiert. Das DNA-Pellet wurde zweifach mit 70\%igem ETOH gewaschen, getrocknet und mit $100 \mu$ l Sperminpuffer vermischt. Die Proben wurden über Nacht bei Raumtemperatur inkubiert, am nächsten Tag für 10 min bei 14000 RPM zentrifugiert und zweimal mit 70\%igem ETOH gewaschen. Anschließend wurde die DNA getrocknet und in $50 \mu \mathrm{l} 1 \mathrm{x}$ TE suspendiert. Zur Überprüfung der DNA Qualität und zur Bestimmung der DNA-Konzentration (vgl. 2.8.4) wurden $5 \mu$ Probe auf ein 1\%iges Agarosegel aufgetragen und elektrophoretisch aufgetrennt. Bis zur weiteren Verwendung wurden die DNA-Proben bei $-20^{\circ} \mathrm{C}$ gelagert.

\subsubsection{Quantifizierung der extrahierten DNA und Geldokumentation}

Zum Angleichen unterschiedlicher DNA-Konzentrationen wurde die DNA-Dichte der mittels CTAB Methode extrahierten Proben densitometrisch bestimmt. Hierzu wurde als Größenstandard $\lambda$-DNA mit 10, 25, 50, 75 ng und $5 \mu$ l Probe auf ein 1\%iges Agarosegel aufgetragen und elektrophoretisch aufgetrennt. Die Dokumentation erfolgte unter UV-Licht über eine Videokamera mit Filter und der Geldokumentationssoftware Multi-Analyst (Geldoc System Bio Rad, München). Mit Hilfe dieser Software wurde durch densitometrische Messung der Größenstandards und der DNA-Proben und deren Abgleich, die DNA-Konzentration in den Proben bestimmt. Anschließend wurden die Proben durch Verdünnung auf eine einheitliche DNA-Konzentration eingestellt und bis zur weiteren Verwendung bei $-20^{\circ} \mathrm{C}$ gelagert.

\subsubsection{Real-time PCR Amplifikation}

Zur Quantifizierung der DNA von V. longisporum wurden die Verticillium-spezifischen Primer OLG 70 (5'-3' CAG CGA AAC GCG ATA TGT AG) und OLG 71 (5'-3' GGC TTG TAG GGG GTT TAG A) verwendet, die in der Lage sind, ein sowohl in 
$V$. longisporum als auch in $V$. dahliae vorkommendes DNA-Fragment zu amplifizieren (Eynck et al., 2007).. Für die Amplifikation und die Analyse der Schmelzkurve wurde ein i-Cycler System (Fa. BioRad, Hercules, USA) verwendet. Die Zusammensetzung des PCR Reaktionsmix und der Ablauf des PCR Programmes sind in Tab. 7 und Tab. 8 dargestellt.

Tab. 7: Zusammensetzun des PCR-Reaktionsmix zum quantitativen Nachweis von Verticillium-DNA; Gesamtvolumen pro Reaktion $25 \mu \mathrm{l}$.

\begin{tabular}{lccc}
\hline Chemikalien & Konzentration & Endkonzentration & $\mu \mathrm{l}$ pro Reaktion \\
\hline $\mathrm{H}_{2} \mathrm{O}$ bidest. & & & 11,8 \\
$10 \mathrm{x}$ Puffer & $10 \mathrm{x}$ & $1 \mathrm{x}$ & 2,5 \\
$\mathrm{MgCl}_{2}$ & $25 \mathrm{mM}$ & $3 \mathrm{mM}$ & 3 \\
$\mathrm{dNTP}$ & $10 \mathrm{mMe}$ & $200 \mu \mathrm{M}$ & 0,5 \\
F-Primer OLG 70 & $10 \mu \mathrm{M}$ & $0,3 \mu \mathrm{M}$ & 0,75 \\
R-Primer OLG 71 & $10 \mu \mathrm{M}$ & $0,3 \mu \mathrm{M}$ & 0,75 \\
Taq Polymerase & $5 \mathrm{U} / \mu \mathrm{l}$ & $1 \mathrm{U}$ & 0,2 \\
SybrGreen & $1: 1000$ & $1: 100000$ & 0,25 \\
Fluorescein & $1 \mu \mathrm{M}$ & $10 \mathrm{nM}$ & 0,25 \\
Probe & & & 5 \\
\hline
\end{tabular}

Tab. 8: PCR-Programm zum Nachweis von Verticillium.

\begin{tabular}{cccc}
\hline Programm & Schritt & Zeit & Temperatur $\left({ }^{\circ} \mathrm{C}\right)$ \\
\hline 1 & Initiale Denaturierung & $2 \mathrm{~min}$ & 94 \\
2 & Denaturierung & $40 \mathrm{~s}$ & 94 \\
3 & Annealing & $30 \mathrm{~s}$ & 59 \\
4 & Elongation & $40 \mathrm{~s}$ & 72 \\
& Schritt 2-4 36 fach Wdh & & 72 \\
\hline
\end{tabular}

Die Filtereinstellung für Anregung und Emission des Fluoreszenzfarbstoffes SybrGreen lagen bei $490 \pm 10 \mathrm{~nm}$ und $530 \pm 15 \mathrm{~nm}$. Eine Quantifizierung der Verticillium-DNA wird durch Messung der Fluoreszenzsignale durch den Fluoreszenzdetektor des Thermocyclers möglich. Die messbare Fluoreszenz nimmt dabei proportional zur Menge an Verticillium-DNA in der Probe zu. Durch den Vergleich der ct-Werte „Cycle 
Treshold“ der untersuchten Proben, mit den gemessenen ct-Werten bekannter Standards von Verticillium-DNA (1, 5, 10, 25, 50, 100, 200 pg pro Reaktion), konnte die DNAMenge von Verticillum in den Proben bestimmt werden.

\subsection{Laboruntersuchungen}

\subsubsection{Antagonismus-Test nach Fokkema}

Mit dem Fokkema-Tests (Fokkema, 1973) wurde das antagonistische Potential von M. ochracea auf das Myzelwachstum von D. tritici-repentis, F.graminearum, $P$. lingam und $V$. longisporum überprüft. OA-Nährmedium bewachsen mit M. ochracea wurde mit einem sterilen Skalpell in 0,5 cm breite und ca. 2,5 cm lange Streifen geschnitten. Aus PDA oder V8 Platten, die mit dem entsprechenden Pathogen bewachsenen waren, wurden Plugs mit einem Korkbohrer ausgestochen. Der Test wurde wie in Abb. 1 dargestellt angesetzt und es wurden die Agarstreifen und Agarplugs mit der myzelbewachsenen Fläche auf das Testmedium gegeben. Der Test wurde durch Messung des Myzelwachstums zu unterschiedlichen Zeitpunkten ausgewertet. Darüber hinaus wurde die Bildung von Hemmzonen zwischen Antagonist und Pathogen erfasst. Die Hemmung des radialen Wachstums (\%) wurde nach folgender Formel berechnet:

Hemmung $(\%)=(d-c) / d \times 100$
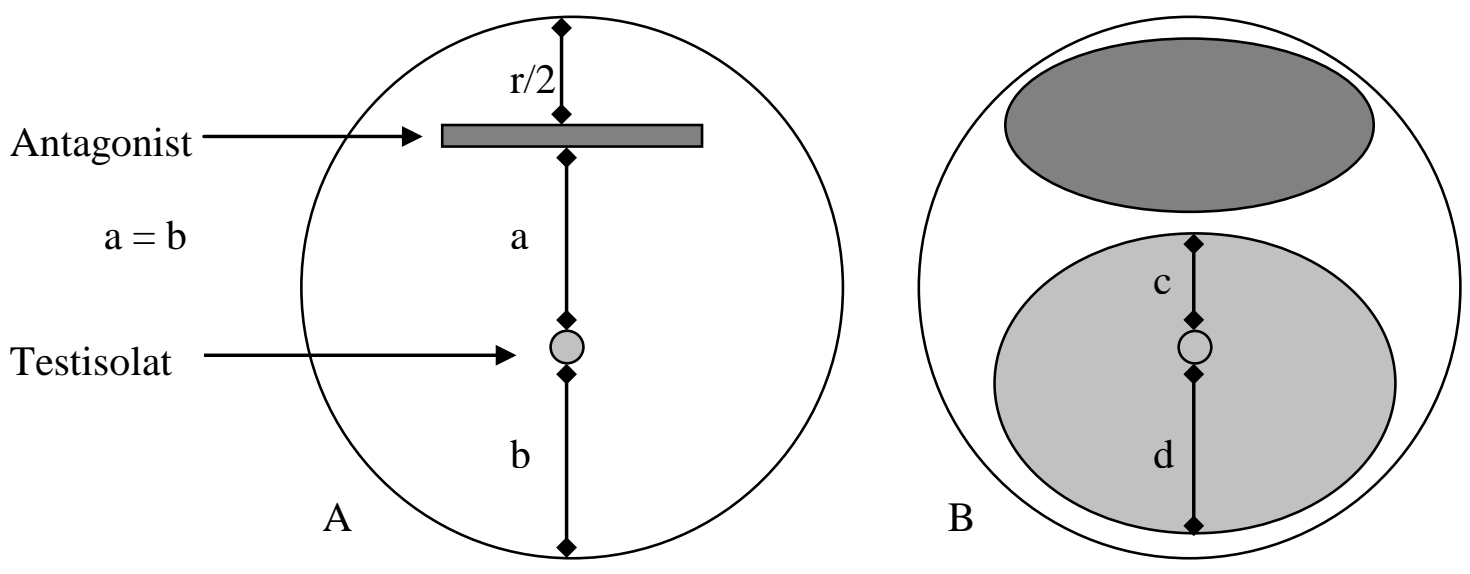

Abb. 1: A: Anordnung von Antagonist und Testisolat auf dem Nährmedium; B: Messung des Testisolates zur Berechnung der Hemmung (\%); nach Fokkema, 1973. 


\subsubsection{Keimtest mit Mikrosklerotien}

Für die in vitro Untersuchungen wurden ausschließlich saubere, bakterienfreie Mikrosklerotien mit einer hohen Keimfähigkeit (>90\%) verwendet. Zur Überprüfung des Reinheitsgrades und der Keimfähigkeit, wurden je 40 Mikrosklerotien der Fraktionsgröße (200-400 $\mu \mathrm{m})$ mit einer, mit Wasser befeuchteten Lanzettnadel, gleichmäßig auf V8 Nährmedium verteilt. Die Platten wurden für 7 Tage bei $20^{\circ} \mathrm{C}$ im Dunkeln inkubiert und es wurde die Keimfähigkeit durch Auszählen der gekeimten Mikrosklerotien bestimmt.

Zur Überprüfung der Mikrosklerotienkeimrate und der Mikrosklerotienneubildung von V. longisporum (Vl 43) und V. dahliae (Vd 73) in Abhängigkeit von der Temperatur wurden Mikrosklerotien (siehe oben) auf PDA Nährmedium ausplattiert und für 11 Tage bei 4, 8, 12, 16, 20, 24, 28 und $32^{\circ} \mathrm{C}$ im Dunkeln inkubiert. Die Mikrosklerotienkeimung und die Mikrosklerotienneubildung wurde täglich durch Auszählen bestimmt und die Keimrate und Mikrosklerotienbildungsrate (\%) berechnet.

\subsubsection{Plattentest zur Überprüfung der mykoparasitischen Wirkung von M. ochracea auf Mikrosklerotien von Verticillium spp. in vitro}

Um das mykoparasitische Potential von M. ochracea auf Mikrosklerotien von Verticillium spp. zu überprüfen wurde ein standardisierter in vitro Test (Filterplättchentest) etabliert. Es wurden je 40 Antibotikumtestblättchen (Rotilabo Testblättchen 6 mm, Roth, Karlsruhe) gleichmäßig auf sterilem WA in Petrischalen verteilt. Jedes Testblättchen wurde mit je einem sterilen Mikrosklerotium (Fraktionsgröße 200-400 $\mu \mathrm{m}$ ) mit Hilfe einer feuchten Lanzettnadel bestückt und mit $5 \mu$ l Sporensuspension von M. ochracea bzw. als Kontrolle mit $\mathrm{H}_{2} \mathrm{O}$ beimpft. Je nach Versuchsansatz wurden die Sporendichte von $M$. ochracea und die Inkubationsbedingungen variiert. Nach erfolgter Inkubation auf WA wurden die Mikrosklerotien auf V8 Nährmedium überimpft, für 7 Tage bei $20^{\circ} \mathrm{C}$ im Dunkeln inkubiert und die Keimung bzw. Mortalität der Mikrosklerotien visuell bonitiert. Gekeimte Mikrosklerotien bildeten auf V8 Nährmedium einen Hof mit neuen Mikrosklerotien (Abb. 2A). Nicht gekeimte Mikrosklerotien waren von weißem Myzel überwachsen (Abb. 2B). Dieses wurde nach mikroskopischen Untersuchungen als Myzel von M. ochracea identifiziert. In einigen Versuchen wurden 
partiell gekeimte Mikrosklerotien bonitiert. In diesem Fall konnte die Mikrosklerotienkeimung durch $M$. ochracea nicht vollständig unterdrückt werden und es bildeten sich vereinzelt Mikrosklerotien aus (Abb. 2B).

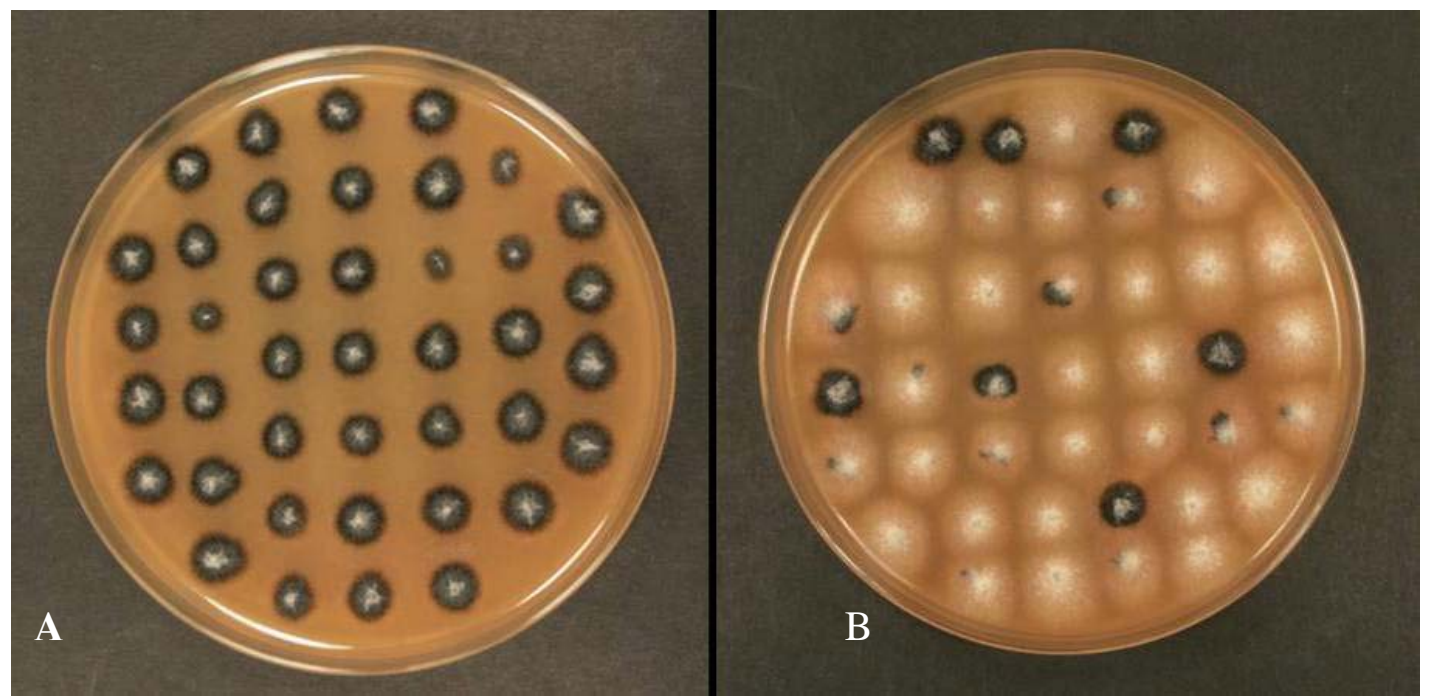

Abb. 2: A: V8-Agarplatten mit vollständig gekeimten Mikrosklerotien von Verticillium (schwarzer Mikrosklerotienhof); B: Vollständig gekeimten Mikrosklerotien (schwarzer Mikrosklerotienhof), partiell gekeimte Mikrosklerotien (weißes Myzel mit vereinzelt Mikrosklerotien) und nicht gekeimte Mikrosklerotien (weißer Myzelbewuchs) nach behandlung mit $5 \mu$ l Sporensuspension von $M$. ochracea $\left(1 \times 10^{6}\right.$ Sporen/ml). Inkubation für 7 Tage bei $20^{\circ} \mathrm{C}$ im Dunkeln.

\subsubsection{Rapsstängelversuche mit $V$. longisporum und $M$. ochracea}

Diese Versuche wurden nach verschiedenen Versuchsansätzen gestaltet. Im ersten Ansatz wurde das Wachstum und die Pyknidienbildung von M. ochracea auf sterilen Rapsstängeln während der Inkubation bei Licht und Dunkelheit untersucht. Hierfür wurden sterile Rapsstängel in einer Sporensuspension von M. ochracea $\left(1 \mathrm{x} 10^{6}\right.$ Sporen/ml) tauchinokuliert und je 4 Rapsstängelstücke auf WA ausplattiert. Die Inkubation erfolgte für 15 Tage bei $20^{\circ} \mathrm{C}$ und $14 \mathrm{~h}$ Licht (L 18W/30, Fa. Osram), $10 \mathrm{~h}$ Dunkelheit bzw. 24 h Dunkelheit. Ausgewertet wurde dieser Versuch durch Auszählen der Pyknidien pro cm Rapsstängel.

In einem weiteren Versuchsansatz wurde die mykoparasitische Wirkung von $M$. ochracea auf $V$. longisporum und sterilen Rapsstängeln als Nährstoffquelle untersucht. Hierfür wurden Rapsstängel in einer Mischsporensuspension bestehend aus M. ochracea und V. longisporum $\left(1 \times 10^{6} \mathrm{Vl} 43,1 \times 10^{6}\right.$ M. ochracea Sporen/ml) koinokuliert. Als Kontrolle wurden Rapsstängel in Sporensuspensionen von M. ochracea $\left(1 \times 10^{6}\right.$ Sporen / ml) oder V. longisporum $\left(1 \times 10^{6}\right.$ Vl 43 Sporen/ml) 
tauchinokuliert. Es wurden je vier Rapsstängel auf WA ausplattiert und für 19 Tage bei $20^{\circ} \mathrm{C}$ im Dunkeln inkubiert.

In einem weiteren Versuchsansatz wurden unterschiedlich stark mit Mikrosklerotien von Vl 43 bewachsene Rapsstängel (vgl. 2.4.2) in einer Sporensuspension von M. ochracea ( 1 x $10^{6}$ Sporen/ml) bzw. $\mathrm{H}_{2} \mathrm{O}$ tauchinokuliert und je vier Rapsstängel auf WA ausplattiert. Diese wurden für 19 Tage bei $20^{\circ} \mathrm{C}$ im Dunkeln inkubiert.

Der Abbau des Inokulums von V. longisporum wurde durch Quantifizierung der DNA von V. longisporum mittels Real-time PCR und über Quantifizierung der Sporendichte von V. longisporum erfasst. Hierfür wurde die Hälfte des Ansatzes (2 Rapsstängelstücke pro WA) gewogen, in $5 \mathrm{ml}$ Wasser gegeben und die Sporen mittels Vortexen suspendiert. Die Auszählung der Sporendichte von Vl 43 erfolgte mittels Thomakammer. Eine Besiedlung der Rapsstängel mit M. ochracea wurde mittels qualitativer PCR untersucht.

\subsubsection{Interaktion von M. ochracea mit F. graminearum in vitro}

Die Interaktionsstudien zwischen $M$. ochracea und F. graminearum wurden nach unterschiedlichen Versuchsansätzen durchgeführt.

Im ersten Versuchsansatz wurden mit Myzel von Fg 12 bewachsene und rückgetrocknete Haferkörner in einer Sporensuspension von M. ochracea $\left(1 \times 10^{6}\right.$ Sporen $\left./ \mathrm{ml}\right) \mathrm{bzw}$. Wasser tauchinokuliert und je 20 Haferkörner auf einer WA-Platte ausplattiert. Die Petrischalen wurden für 3 Tage bei Raumtemperatur inkubiert, bis die Haferkörner durch das Myzelwachstum im WA verankert waren. Die Petrischalen wurden im Anschluss mit dem Deckel nach unten auf ein Gitter gestellt und unterhalb des Gitters eine Lichtquelle (L 18W/30, Fa. Osram) platziert. Somit wurden die Askosporen von F. graminearum nach der Perithezienbildung und beginnender Askosporenausschleuderung im Petrischalendeckel aufgefangen. Die Inkubation erfolgte bei $20^{\circ} \mathrm{C}$ und Dauerlicht. Es wurden die aufgefangenen Askosporen nach 15 Tagen und 30 Tagen mit jeweils $4 \mathrm{ml} \mathrm{H}_{2} \mathrm{O}$ + Tween von dem Petrischalendeckel abgeschwemmt und die Askosporendichte mit einer Thomakammer bestimmt.

In einem weiteren Versuchsansatz wurden perithezienbewachsene Haferkörner in Sporensuspensionen von M. ochracea oder M. ochracea WG $\left(1 \times 10^{4}, 1 \times 10^{8}\right.$ Sporen/ml) tauchinokuliert. Als Kontrolle wurden perithezienbewachsene Haferkörner mit Wasser inokuliert. Es wurden je 20 Haferkörner auf einer WA-Platte ausplatiert und 
für 15 Tage inkubiert. Die Inkubation, die Gewinnung und die Bestimmung der Askosporendichte erfolgte wie oben beschrieben.

\subsubsection{Quarkschalentest mit V. longisporum und M. ochracea}

\subsubsection{Bestimmung der maximalen Wasserhaltekapazität (WHK)}

Die Bestimmung der maximalen Wasserhaltekapazität wurde nach Laermann (1972) durchgeführt. Die zu untersuchende Erde bzw. der Sand wurden gesiebt (3 mm Siebgröße) und bei $95^{\circ} \mathrm{C}$ für $72 \mathrm{~h}$ im Trockenschrank getrocknet. Kunststoffröhren $(\varnothing 5 \mathrm{~cm})$ mit einem Siebverschluss wurden mit einer 2-2,5 cm hohen Grobkiesschicht befüllt und das Leergewicht bestimmt (Gewicht 1). Anschließend wurden die Kunststoffröhren mit 200 g trockener Erde bzw. Sand befüllt. Die Bodensubstrate wurde für 2 h in einem mit Wasser befüllten Eimer gewässert, anschließend für 15 min. auf einem Siebgitter abgetropft und auf Saugpapier gestellt. Das Saugpapier wurde mehrmals gewechselt, bis dieses keine Flüssigkeit mehr aufnahm. Anschließend wurde das Endgewicht bestimmt (Gewicht 2). Die WHK wurde wie folgt berechnet:

Maximale WHK (g/100g Boden) = (Gewicht 2 - Gewicht $1-200 g) / 2$

Tab. 9: Nährstoffgehalte und maximale Wasserhaltekapazitäten (Max. WHK) der Bodensubstrate die für Fungistasis Untersuchungen, Quarkschalentests und Gewächshausversuche verwendet wurden. Die Felderde stammt von dem Versuchsstandort „Große Lage“ Göttingen-Weende. Nährstoffgehalte des Lößlehms nach vonTiedemann, (1993).

\begin{tabular}{ccccccc}
\hline & $\mathrm{N}(\%)$ & $\begin{array}{c}\mathrm{P}_{2} \mathrm{O}_{5} \\
\mathrm{mg} / 100 \mathrm{~g}\end{array}$ & $\begin{array}{c}\mathrm{MgO} \\
\mathrm{mg} / 100 \mathrm{~g}\end{array}$ & $\begin{array}{c}\mathrm{K}_{2} \mathrm{O} \\
\mathrm{mg} / 100 \mathrm{~g}\end{array}$ & $\mathrm{pH}$ & $\begin{array}{c}\text { Max. WHK } \\
\mathrm{g} / 100 \mathrm{~g}\end{array}$ \\
\hline Lößlehm & 0,02 & 0,7 & --- & 5 & 7,5 & 39 \\
Felderde & --- & 25,3 & 14,9 & 16,9 & 6,6 & 50,3 \\
Sand & --- & --- & --- & --- & --- & 18,4 \\
\hline
\end{tabular}

\subsubsection{Interaktion von $M$. ochracea mit $V$. longisporum im Boden}

Im ersten Versuchsansatz wurde eine mögliche Interaktion zwischen $M$. ochracea und V. longisporum auf Rapsstängeln in sterilem Sand bzw. unsterilem Boden untersucht. Hierfür wurden kleine Netzsäcke (Maschenweite 2mm) mit je vier, mit Mikrosklerotien von Vl 43, steril bewachsenen Rapsstängel (40-70\% Mikrosklerotiendeckungsgrad) befüllt, und in einer Sporensuspension von M. ochracea $\left(1 \times 10^{6}\right.$ Sporen/ml) bzw. 
Wasser als Kontrolle tauchinokuliert. Es wurden Quarkschalen mit 100 g unsteriler Erde bzw. sterilem Sand befüllt und mit Wasser auf 40\% WHK eingestellt. Die Netzsäcke wurden auf die Erdsubstrate in die Quarkschalen gegeben, mit $100 \mathrm{~g}$ sterilem Sand bzw. unsteriler Erde bedeckt, die wiederum auf 40\% WHK eingestellt wurden. Somit konnte eine homogene Durchfeuchtung der Bodensubstrate gewährleistet werden. Zum besseren Gasaustausch wurden die Deckel der Quarkschalen mit 2-3 Luftlöchern versehen. Die Proben wurden für 8 Wochen bei $20^{\circ} \mathrm{C}$ im Dunkeln inkubiert und die WHK durch wöchentliches Wiegen nachjustiert. Ein Abbau des Inokulums von $V$. longisporum wurde durch Quantifizierung der DNA von V. longisporum mittels Real-time PCR untersucht. Eine Besiedlung der Rapsstängel mit M. ochracea wurde über PCR-Untersuchungen ermittelt.

In einem weiteren Versuchsansatz wurde $1 \mathrm{~g}$ stark mit Mikrosklerotien von V. longisporum bewachsenes, unsteriles Rapsstroh aus den Feldversuchen in Netzsäcke eingewogen. Diese wurden in einer Sporensuspension von M. ochracea $\left(1 \times 10^{6}\right.$ Sporen/ml) bzw. Wasser als Kontrolle tauchinokuliert. Anschließend wurden die Netzsäcke s.o. auf bzw. in unsteriler Erde, steriler Erde, unsterilem Sand oder sterilem Sand für 8 Wochen bei einer WHK von 40\% inkubiert. Das Wachstum von M. ochracea auf unsterilem mit Mikrosklerotien besiedeltem Rapsstroh wurde mittels qualitativer PCRUntersuchung ermittelt.

\subsubsection{Wirkung der Bodenfungistasis auf die Sporenkeimung von M. ochracea}

Im ersten Versuchsansatz wurde die Wirkung der Bodenfungistasis von verschiedenen frischen und autoklavierten Böden (Herkunftsbezeichnungen: Felderde (Tab. 9), Botanischer Garten (keine genauen Angaben), Dauergrünland (keine genauen Angaben)) auf die Sporenkeimung von M. ochracea ermittelt.

In einem weiteren Versuchsansatz wurde eine mögliche Reduktion der Bodenfungistasis durch Autoklavieren bzw. Zugabe von Glukoselösung zu den frischen Erdsubstraten untersucht. Die Versuche wurden mit „Felderde“ des Feldversuchsstandort „Große Lage“ und mit „Lößlehm“ (Felderde, Lößlehm Tab. 9) durchgeführt. Als Kontrolle wurde die Sporenkeimung von M. ochracea auf frischen Erdsubstraten und Wasseragar untersucht. 
Vor dem Ansetzen der Versuche wurden die Böden für eine Woche bei mittlerer Bodenfeuchtigkeit und Raumtemperatur inkubiert. In den Versuchsvarianten mit autoklavierten Erdsubstraten wurden diese 24 h vor Gebrauch autoklaviert um ein vollständiges Auskühlen zu gewährleisten.

Für beide Versuchsansätzen wurden ca. $50 \mathrm{~g}$ frischer bzw. autoklavierter Boden in Polystyrolpetrischalen eingewogen, mit Wasser versetzt, und mit einem Spatel zu einer speckigen, glatten Oberfläche verstrichen. In den Glukosevarianten wurde frischer Boden, anstelle von Wasser, mit $3 \mathrm{ml}$ 10\%iger bzw. 2\%iger Glukoselösung versetzt. Anschließend wurden $10 \mathrm{ml}$ Sporensuspension von M. ochracea (1 x $10^{6}$ Sporen/ml) auf eine Celluloseacetatmembran in einem Kleinexsikkators gegeben und die Sporen durch Vakuum auf die die Membran gezogen. Es wurde je eine halbe Membran auf ein Bodensubstrat bzw. Wasseragar gegeben und ein guter Oberflächenkontakt hergestellt. Die Inkubation erfolgte für 48 h bei Raumtemperatur.

Anschließend wurden die Membranen auf eine Glatte Unterlage überführt, mit 50-100 $\mu \mathrm{l}$ Wasser vesetzt und die Sporen durch Reiben mit einer Impföse gelöst. Die Anzahl gekeimter und nicht gekeimter Sporen wurde mit Hilfe einer Thoma Zählkammer bestimmt. Es wurde die Keimrate (\%) berechnet und durch Verrechnung mit der Kontrolle (Wasseragar) die relative Sporenkeimrate (rSKR in \%) von $M$. ochracea bestimmt. Die relative Sporenkeimrate spiegelt dabei die Bodenfungistasis wieder. Umso höher die relative Sporenkeimrate ist desto geringer ist die Bodenfungistasis in dem untersuchten Bodensubstrat.

\subsection{Entwicklung einer PCR zum Nachweis von $M$. ochracea}

\subsubsection{Anzucht von M. ochracea und DNA-Extraktion}

M. ochracea wurde bei $20^{\circ} \mathrm{C}$ in Czapek Dox Broth auf einem Schüttelinkubator angezogen. Das Myzel von M. ochracea wurde für $72 \mathrm{~h}$ gefriergetrocknet und für $90 \mathrm{~s}$ bei $20 \mathrm{~Hz}$ in einer Schwingmühle fein vermahlen. Die Extraktion der DNA wurde mit dem DNeasy Plant Mini Kit der Firma Qiagen (Fa. Qiagen, Hilden) durchgeführt. 


\subsubsection{Amplifikation der „Internal Transcribed Spacer“ Region}

Die Amplifikation der „Internal Transcribed Spacer“ (ITS) Region erfolgte nach der von White et al. (1991) beschriebenen Methode. Zur Amplifikation ribosomaler DNA (rDNA) Fragmente, wurden eukaryonten spezifische Primer ITS 4 (5'-3' TCCTCCGCTTATTGATATGC) und ITS 5 (5'-3' GGAAGTAAAAGTCGTAACAAGG) verwendet. Der ITS 5 Primer bindet an der kleinen rDNA Untereinheit und der ITS 4 Primer an der großen rDNA Untereinheit. Die Zusammensetzung des PCR Reaktionsmix und der Ablauf des PCR-Programmes sind in Tab. 10 und Tab. 11 dargestellt.

Tab. 10: Zusammensetzung des PCR Reaktionsmix für eine Reaktion zur Amplifikation der ITS-Region.

\begin{tabular}{lccc}
\hline Chemikalien & Konzentration & Endkonzentration & $\mu$ l pro Reaktion \\
\hline $\mathrm{H}_{2} \mathrm{O}$ bidest. & & & 13,8 \\
$10 \mathrm{x}$ Puffer & $10 \mathrm{x}$ & $1 \mathrm{x}$ & 2,5 \\
$\mathrm{MgCl}_{2}$ & $25 \mathrm{mM}$ & $1,5 \mathrm{mM}$ & 1,5 \\
$\mathrm{dNTP}$ & $10 \mathrm{mMe}$ & $200 \mu \mathrm{M}$ & 0,5 \\
ITS 4 & $10 \mu \mathrm{M}$ & $0,3 \mu \mathrm{M}$ & 0,75 \\
ITS 5 & $10 \mu \mathrm{M}$ & $0,3 \mu \mathrm{M}$ & 0,75 \\
Taq Polymerase & $5 \mathrm{U} / \mu \mathrm{l}$ & $1 \mathrm{U}$ & 0,2 \\
Probe & & & 5 \\
\hline
\end{tabular}

Tab. 11: PCR-Programm zur Amplifikation der ITS-Region.

\begin{tabular}{cccc}
\hline Programm & Schritt & Zeit & Temperatur $\left({ }^{\circ} \mathrm{C}\right)$ \\
\hline 1 & Denaturierung & $3 \mathrm{~min}$ & 94 \\
2 & Annealing & $1 \mathrm{~min}$ & 54 \\
3 & Elongation & $1 \mathrm{~min}$ & 72 \\
4 & Denaturierung & $2 \mathrm{~min}$ & 94 \\
5 & Annealing & $1 \mathrm{~min}$ & 54 \\
6 & Elongation & $1 \mathrm{~min}$ & 72 \\
& Schritt 4-6, 4-fach Wdh. & & \\
7 & Denaturierung & $1 \mathrm{~min}$ & 94 \\
8 & Annealing & $1 \mathrm{~min}$ & 54 \\
9 & Elongation & $1 \mathrm{~min}$ & 72 \\
10 & Schritt 7-8 30 fach Wdh. & & \\
\hline
\end{tabular}




\subsubsection{Extraktion von DNA-Fragmenten aus Agarosegelen}

Im Anschluss an die PCR Reaktion wurden $10 \mu \mathrm{l}$ jeder Probe und $1 \mu \mathrm{l}$ des Größenstandards 100 bp Leiter plus auf ein 1,2\%iges TAE-Agarosegel aufgetragen und bei 3 V/cm für 2 h elektrophoretisch aufgetrennt. Zur Extraktion des DNA-Fragments aus dem Agarosegel wurde der zur Färbung vorgesehne Teil des Agarosegels für $10 \mathrm{~min}$ in einem Ethidiumbromid-Wasserbad $(2 \mu \mathrm{g} / \mathrm{ml})$ angefärbt und für $10 \mathrm{~min}$ in einem Wasserbad inkubiert, um das überschüssige Ethidiumbromid zu entfernen. Anschließend wurde die Position der gesuchten Bande (PCR-Produkt aus 2.10.2) unter UV licht auf einem Transilluminator mit Hilfe eines Skalpells gekennzeichnet. Nach Abschalten des UV-Lichtes wurde der ungefärbte Teil des Agarosegels angelegt, das gewünschte Fragment aus dem Gel herausgeschnitten und der Agaroseblock gewogen. Die Extraktion der DNA aus dem Agaroseblock wurde mit dem Gel Extraktions Kit QIAEX II (Fa. Quiagen, Hilden) durchgeführt.

\subsubsection{Ligationsreaktion}

Die Ligation der ITS-DNA-Fragmente erfolgte in den Plasmid-Vektor pGEM-Teasy (Fa. Promega, Madison, USA). Zur Ligationsreaktion wurden ausschließlich Enzyme und Chemikalien der Firma Promega (Madison, USA) verwendet. Es wurden $5 \mu \mathrm{l} 2$ x Rapid ligation buffer mit 1 l (50 ng) pGEM-Teasy, $2 \mu \mathrm{l}$ (ca. 30 ng) Insert DNA und $1 \mu \mathrm{l}$ T4 DNA Ligase (3 Weiss units/ $\mu \mathrm{l}$ ) in 0,5 ml Eppendorfgefäßen vereint. Anschließend wurden die Reaktionsansätze mit $\mathrm{H}_{2} \mathrm{O}$ bidest. auf $10 \mu \mathrm{l}$ aufgefüllt und durch mehrfaches Pipetieren gut vermischt. Als Positivkontrolle wurde die Insert-DNA durch eine Kontroll Insert-DNA ersetzt. Bis zur vollständigen Ligationsreaktion wurde das Gemisch über Nacht bei $4^{\circ} \mathrm{C}$ inkubiert.

\subsubsection{Transformation in Escherichia coli $(E$. coli)}

Zur Vermehrung der rekombinanten Plasmide in vitro wurden diese in chemokompetente E. coli transformiert. Für die Transformation wurden bei $-80^{\circ} \mathrm{C}$ gelagerte chemokompetente E.coli auf Eis aufgetaut. Es wurden $2 \mu$ Ligationsansatz in 1,5 ml vorgekühlte Eppendorfgefäße überführt, mit $100 \mu$ l chemokompetenter Zellen vermischt und für 20 min auf Eis inkubiert. Die eigentliche Transformation wurde durch eine Wärmebehandlung für $50 \mathrm{~s}$ bei $42^{\circ} \mathrm{C}$ im Wasserbad durchgeführt. Nach der Wärmebehandlung wurden die Transformationsansätze mit $950 \mu \mathrm{l}$ SOC Medium ver- 
setzt und für $1,5 \mathrm{~h}$ bei $37^{\circ} \mathrm{C}$ im Wasserbad inkubiert. Zur Selektion transformierter $E$. coli wurden je zweimal $100 \mu \mathrm{l}$ von jedem Ansatz auf LB $_{\mathrm{AP}}$ Festmedium ausplattiert und über Nacht bei $37^{\circ} \mathrm{C}$ inkubiert.

\subsubsection{Isolierung von Plasmiden aus E. coli}

Zur Vermehrung wurden einzelne E. coli Kolonien mit Hilfe einer sterilen Pipettenspitze von dem $L_{\mathrm{AP}}$ Festmedium isoliert und in sterile Reagenzgläser überführt die mit $3 \mathrm{ml} \mathrm{LB} \mathrm{AP}_{\mathrm{P}}$ Flüssigmedium versetzt waren. Zur Vermehrung wurden die Reagenzgläser über Nacht bei $37^{\circ} \mathrm{C}$ auf einem Rotationsinkubator inkubiert.

Am nächsten Tag wurde die Bakterienkultur in $2 \mathrm{ml}$ Eppendorfgefäße überführt, für 5 min bei 8000 RPM zentrifugiert und der Überstand verworfen. Jeder Ansatz wurde mit $200 \mu$ l GLC Puffer + Lysozym gemischt, für 20 min bei Raumtemperatur inkubiert, mit $250 \mu \mathrm{l}$ HS-Puffer gemischt und für 30 min auf Eis inkubiert. Anschließend wurden die Proben für 10 min bei $4^{\circ} \mathrm{C}$ und 13000 RPM zentrifugiert, der Überstand in ein neues Reaktionsgefäß überführt, mit 0,6 Volumen Isopropanol vermischt und für $10 \mathrm{~min}$ bei Raumtemperatur inkubiert. Die Proben wurden erneut für 10 min bei 13000 RPM zentrifugiert, der Überstand verworfen und das Pellet zweimal mit 70\%igem ETOH gewaschen und getrocknet. Das Pellet wurde anschließend in $200 \mu \mathrm{l} 1 \mathrm{x} \mathrm{TE}$ aufgenommen.

\subsubsection{Ethidiumbromid-Phenolextraktion}

Zur Entfernung von Proteinen die die DNA-Sequenzierung negativ beeinflussen, wurden die Proben mittels Ethidiumbromid-Phenolextraktion gereinigt. Die Plasmidproben $(200 \mu \mathrm{l})$ wurden mit $150 \mu \mathrm{l}$ 7,5 M Ammonium-Acetat Lösung und $15 \mu \mathrm{l}$ Ethidiumbromid (10 mg/ml) gemischt und für 10 min bei Raumtemperatur inkubiert. Anschließend wurden die Proben mit $150 \mu \mathrm{l}$ Tris-äquilibriertem Phenol versetzt und für 5 min geschüttelt. Die Proben wurden mit $150 \mu$ l Chloroform Isoamylalkohol (24:1) versetzt und für 10 min bei 15000 RPM zentrifugiert. Der Überstand wurde in ein neues Eppendorfgefäß überführt, mit 0,7 Volumen Isopropanol vermischt und für 10 min bei 15000 RPM und $4^{\circ} \mathrm{C}$ zentrifugiert. Das Pellet wurde zweimal mit 70\%igem ETOH gewaschen, getrocknet und in $20 \mu \mathrm{H}_{2}$ Obidest. resuspendiert. 


\subsubsection{DNA Sequenzierung}

Zur Bestimmung der DNA-Konzentration von Plasmiden die aus E. coli extrahiert wurden, wurde $5 \mu$ l Probe und $1 \mu$ l Größenstandard (100 bp Plus DNA Leiter) auf ein 1,2\%iges Agarosegel aufgetragen, für $3 \mathrm{~h}$ elektrophoretisch aufgetrennt und die Plasmid-DNA-Konzentration densitometrisch bestimmt. Die Plasmid-DNA wurde auf ca. $50 \mathrm{ng} / \mu \mathrm{l}$ eingestellt. Die Sequenzierung der Insert-DNA wurde von der Firma Eurofins MWG (Ebersberg, Deutschland) durchgeführt.

\subsubsection{Nachweis von M. ochracea mittels PCR}

\subsubsection{Primerdesign, PCR-Optimierung und Spezifitätstestung}

Die Primer von $M$. ochracea wurden basierend auf dem sequenzierten ITS-Fragment von M. ochracea abgeleitet. Dabei erfolgte die Primerentwicklung auf Grundlage von Polymorphismen zu anderen bedeutenden Schadpilzen an Getreide und Raps. Die Primersynthese wurde von der Firma Invitrogen (Karlsruhe) durchgeführt.

Zur PCR-Optimierung wurden die Primerpaare bei verschiedenen Annealing-Temperaturen $\left(65 \pm 5^{\circ} \mathrm{C}\right)$ und verschiedenen $\mathrm{MgCl}_{2}$-Konzentrationen $(3,1,5,0,5 \mathrm{mM})$ auf Produktausbeute und Produktspezifität getestet.

Die anschließenden Spezifitätstests wurden an bedeutenden im Getreide- und Rapsanbau vorkommenden pilzlichen Pflanzenpathogenen, an Pflanzenmaterial (Winterraps, Winterweizen) und Ackerboden durchgeführt. Darüber hinaus wurden mögliche Kreuzreaktionen zu Coniothyrium minitans einem bedeutenden Mykoparasiten getestet. Die Pilze wurden auf entsprechendem Medium angezogen und die DNA-Extraktion aus Pflanzengewebe und Pilzmyzel mit Hilfe des DNeasy Plant Mini Kits der Firma Qiagen durchgeführt. Die Extraktion der DNA aus Ackerböden erfolgte mittels CTAB Extraktionsmethode mit anschließender zweifacher Sperminfällung.

\subsubsection{PCR Reaktionsmix und Amplifikationsbedingungen}

Es wurde ein Standard PCR Reaktionsmix verwendet. Dieser umfasst ein Gesamtvolumen von $25 \mu \mathrm{l}$ und setzt sich wie in Tab. 12 dargestellt zusammen.

Zur Optimierung der M. ochracea-PCR wurde eine Gradienten-PCR mit einer Annealingtemperatur von $65 \pm 5^{\circ} \mathrm{C}$ in einem nach den in Tab. 13 dargestellten Schritten durchgeführt. 
Tab. 12: Standard PCR Reaktionsmix zum Nachweis von $M$. ochracea bei unterschiedlichen $\mathrm{MgCl}_{2}$ Konzentrationen 0,5, 1,5, 3 mM.

\begin{tabular}{lccc}
\hline Chemikalien & Konzentration & Endkonzentration & $\mu$ l pro Reaktion \\
\hline $\mathrm{H}_{2} \mathrm{O}$ bidest. & & $1 \mathrm{x}$ & 13,8 \\
$10 \mathrm{x}$ Puffer & $10 \mathrm{x}$ & $0,5 / 1,5 / 3 \mathrm{mM}$ & 2,5 \\
$\mathrm{MgCl}_{2}$ & $25 \mathrm{mM}$ & $200 \mu \mathrm{M}$ & $0,5 / 1,5 / 3$ \\
$\mathrm{dNTP}$ & $10 \mathrm{mM}$ & $0,3 \mu \mathrm{M}$ & 0,5 \\
M.o F-Primer & $10 \mu \mathrm{M}$ & $0,3 \mu \mathrm{M}$ & 0,75 \\
M.o R-Primer & $10 \mu \mathrm{M}$ & $1 \mathrm{U}$ & 0,75 \\
Taq Polymerase & $5 \mathrm{U} / \mu \mathrm{l}$ & & 0,2 \\
Probe & & & 5 \\
\hline
\end{tabular}

Tab. 13: PCR Programm für die M. ochracea-PCR bzw. M. ochracea-Gradienten-PCR.

\begin{tabular}{cccc}
\hline Programm & Schritt & Zeit & Temperatur $\left({ }^{\circ} \mathrm{C}\right)$ \\
\hline 1 & Initiale Denaturierung & $5 \mathrm{~min}$ & 94 \\
2 & Annealing & $1 \mathrm{~min}$ & $65 / 65 \pm 5$ \\
3 & Elongation & $3 \mathrm{~min}$ & 72 \\
4 & Denaturierung & $1 \mathrm{~min}$ & 94 \\
5 & Annealing & $1 \mathrm{~min}$ & $65 \pm 5$ \\
6 & Elongation & $1 \mathrm{~min}$ & 72 \\
& Schritt 4-6 30 fach Wdh & & 72 \\
\hline
\end{tabular}

\subsection{Gewächshausversuche mit V. longisporum und M. ochracea}

\subsubsection{Pflanzenanzucht und Wachstumsbedingungen}

Für die Gewächshausversuche wurde die Rapsvarietät „rapid cycling rapeseed“ (RCR, Brassica napus var. napus, Genom ACaacc) verwendet. Dieser wurde von P. H. Williams aus Wisconsin bezogen (Williams \& Hill, 1986) und im Department für Nutzpflanzenwissenschaften, Abteilung Pflanzenpathologie vermehrt. RCR diente als Modellpflanze um eine mögliche Reduktion des Inokulums von $V$. longisporum im Boden durch M. ochracea visuell an morphologischen Parametern der Pflanze und anhand von molekularen Methoden (Real-time PCR Untersuchungen) zu erfassen. 
Dabei hat RCR keinen Vernalisationsanspruch und durchläuft den vollständigen Entwicklungszyklus in Abhängigkeit von der Nährstoffversorgung innerhalb von 60-90 Tagen bei einer Wuchhöhe von 80-120 cm.

Für den Inokulationsstufenversuch mit Mikrosklerotien und die Interaktionsversuche zwischen V. longisporum und M. ochracea im Boden, wurden 150 g eines Lößlehm (Tab. 9) Vermiculit-Gemisches (Fa. Vermiculit Dämmstoffe, Sprockhövel) im Verhältnis 3:1 in Kunststofftöpfe $(7 \times 7 \times 7 \mathrm{~cm})$ eingewogen. Es wurden je nach Versuchsansatz 11 bis 18 Töpfe gleicher Behandlung in eine Plastikschale gestellt und zur Auswertung die Messwerte aller 11 bis 18 Pflanzen zu einer Wiederholung vereinigt. Die Aussaat von RCR erfolgte mit je 3 Samen direkt in den Topf. Nach dem Auflaufen wurden die Pflanzen vereinzelt und die Töpfe direkt bewässert. Nach dem Durchwurzeln der Töpfe wurde die Wasserversorgung über die Bewässerung der Schalen sichergestellt. Eine ausreichende Nährstoffversorgung der Pflanzen wurde durch eine bedarfsgerechte Düngung mit 2 g Hakaphos (15\% N; 15\% $\mathrm{K}_{2} \mathrm{O} ; 11 \% \mathrm{P}_{2} \mathrm{O}_{5} ; 1 \% \mathrm{MgO}$ ) pro Liter Gießwasser in der Hauptwachstumsphase gesichert.

Für den Biotest der Litterbagversuche (vgl. 2.12.1) wurde ein Substratgemisch aus 1 Teil Sand, 2 Teilen Topferde und 2 Teilen gedämpften Kompost verwendet. Die Versuche wurden in Kunstofftöpfen (10 x 10 x 10 cm) auf einer Gießfilz-Kunststofffolienunterlage durchgeführt. Es wurden je 3 Samen RCR ausgesät und nach der Keimung vereinzelt. Anfänglich wurden die Töpfe von oben gegossen. Nach dem Durchwurzeln der Töpfe wurde die Wasserversorgung über Gießfilzwässerung sichergestellt. Eine bedarfsgerechte Düngung erfolgte alle zwei Wochen mit 1 g Hakaphos pro Liter Gießwasser.

Die Gewächshausversuche wurden voll randomisiert angelegt, um Versuchsfehler durch Randeffekte, Temperaturschwankungen, Luftfeuchtigkeitsunterschiede und unterschiedliche Beleuchtungsintensität möglichst gering zu halten. Die Rapspflanzen wurden bei einer Temperatur von $25 \pm 12^{\circ} \mathrm{C}$ und einer Luftfeuchtigkeit von ca. $45 \%$ auf Gewächshaustischen $(85 \mathrm{~cm})$ gehalten. Über den Gewächshaustischen waren Lampen installiert die bei einer 16-stündigen Beleuchtung mindestens 10000 Lux unabhängig von der einfallenden Strahlung lieferten. Eine automatische Temperaturregelung erfolgte beim Überschreiten bzw. Unterschreiten der Solltemperatur $\left(25^{\circ} \mathrm{C}\right)$ durch Öffnen der Dachfenster bzw. Zuschalten der Heizkörper. Um abiotischen Stress zu vermeiden wurden die Rapspflanzen ausreichend mit Wasser versorgt und vor zu hoher Strahlung von außen durch Dachvorhänge geschützt. 
Pflanzenschutzmaßnahmen wurden nur nach Bedarf durch Spritzapplikation durchgeführt. Zur Bekämpfung des echten Mehltaus (Erysiphe cruciferarum) wurde Netzschwefel appliziert und zur Bekämfung von Thripsen und mehliger Kohlblattlaus wurden Insektizidbehandlungen mit Confidor (Imidacloprid) oder Karate-Zeon (LambdaCyhalothrin) durchgeführt.

\subsubsection{Inokulationsstufenversuch mit Mikrosklerotien von V. longisporum}

Der Inokulationsstufenversuch mit Mikrosklerotien wurde durchgeführt um die Eignung von RCR als Fang- bzw. Modellpflanze für den Nachweis unterschiedlicher Inokulumdichten (Mikrosklerotien) von V. longisporum im Boden zu prüfen. Hierfür wurden verschiedene pflanzenmorphologische Parameter zu unterschiedlichen Entwicklungsstadien erfasst. Es wurden 150 g eines Lößlehm-Vermiculit Gemisches mit 200 mg, 100 mg, 50 mg, und 20 mg Mikrosklerotien beimpft und in 7 mm Kunststofftöpfe gegeben. Die verschiedenen pflanzenmorphologischen Parameter wie Pflanzenlänge und visuell bewerteter Befallswert (1-8), wurden destruktiv in BBCH 65, 72 und 75 erfasst. In BBCH 79 wurde nochmals die Pflanzenlänge bestimmt, die Pflanzen anschließend geerntet, für $72 \mathrm{~h}$ bei $95^{\circ} \mathrm{C}$ getrocknet, und die Sprosstrockenmasse bestimmt.

\subsubsection{Bodeninokulation mit M. ochracea WG als Granulat}

Ziel dieses Versuchs war es das mykoparasitische Potential von M. ochracea auf Mikrosklerotien von V. longisporum im Boden bei sehr hohen Inokulationsstufen mit M. ochracea zu testen. Es wurden 150 g Lößlehm-Vermiculit Gemisch mit 100 mg Mikrosklerotien, 100 mg Mikrosklerotien +1 g M.ochracea WG (1,7 x $10^{7}$ Sporen/g Boden) und 100 mg Mikrosklerotien + 5g M. ochracea WG (8,3 x 10 7 Sporen/g Boden) gemischt und in 7 mm Kunststofftöpfe gegeben. Um Einflüsse von M. ochracea WG auf das Pflanzenwachstum auszuschließen wurden als Negativkontrollen 1g bzw. 5 g M. ochracea WG ohne Mikrosklerotien in 150 g Lößlehm-Vermiculit eingemischt. Die Inokulation von M. ochracea WG erfolgte bei diesem Versuch als Granulat um eine homogene Verteilung von M. ochracea im Boden zu gewährleisten. Anschließend wurde RCR als Modellpflanze ausgesät um einen möglichen Mikrosklerotienabbau durch M. ochracea indirekt über die Befallsstärke der Modellpflanzen mit V. longisporum zu quantifizieren. Eine visuelle Erfassung des Modellrapspflanzen- 
befalls mit $V$. longisporum erfolgte destruktiv in BBCH 65 durch Bestimmung des Befallswertes (BW) und durch Erfassung der Pflanzenlänge in BBCH 72. Darüber hinaus wurde in BBCH 79 die Sprosstrockenmasse erfasst und die DNA von V. longisporum im Pflanzengewebe durch Real-time PCR-Untersuchungen quantifiziert.

\subsubsection{Gießapplikation von M. ochracea}

bei diesem Versuchsansatz wurde das mykoparasitische Potential von M. ochracea auf Mikrosklerotien von V. longisporum unter Gewächshausbedingungen mit realistischen, auch unter Feldbedingungen anwendbaren Aufwandmengen untersucht. Es wurden 100 mg Mikrosklerotien in 150 g Lößlehm-Vermiculit eingemischt und in 7 mm Kunststofftöpfe gegeben und Sporensuspensionen von M. ochracea bzw. M. ochracea WG auf die Töpfe gegeben und eingemischt. Pro Topf wurden $42 \mathrm{ml}$ Sporensuspension von M. ochracea bzw. M. ochracea WG mit Sporendichten von 1 x $10^{3}$ Sporen/ml (2,8 x $10^{2}$ Sporen/g Boden) und $1 \times 10^{6}$ Sporen/ml (2,8 x 10 5 Sporen/g Boden) appliziert so dass die WHK des Bodensubstrates ca. 70\% betrug. Als Positivkontrolle wurde das Lößlehm-Vermiculit-Gemisch mit Mikrosklerotien beimpft. Als Negativkontrollen wurde mikrosklerotienfreies Lößlehm-Vermiculit-Gemisch mit Wasser oder Sporensuspension von M. ochracea oder M. ochracea WG ( $\left.10^{6} \mathrm{Sporen} / \mathrm{ml}\right)$ inokuliert. Die Auswertung erfolgte über eine visuelle Bonitur in BBCH 65 und eine Längenmessung in BBCH 75. Darüber hinaus wurde in BBCH 79 die Sprosstrockenmasse erfasst und die DNA von V. longisporum im Pflanzengewebe mittels Real-time PCR quantifiziert.

\subsection{Litterbagversuche}

\subsubsection{Abbau des Inokulums von $V$. longisporum durch $M$. ochracea}

In diesen Versuchsansätzen wurde der Abbau der Mikrosklerotien von V. longisporum durch M. ochracea auf unsterilem Rapsstroh in unterschiedlichen Bodentiefen $(10 \mathrm{~cm}$, 20 cm) untersucht. Hierfür wurden in den Jahren 2007/2008 und 2008/2009 Versuche in Strohabbausäcken (Litterbags) angelegt. Die Litterbags (Maschenweite $8 \mathrm{~cm}$, Fa. Ecotech Umweltmeßsysteme, Bonn) wurden mit stark von V. longisporum befallenem Rapsstroh befüllt, das zuvor mit Hilfe eines Laubschredders auf eine Größe von 1-3 cm zerkleinert wurde. Anschließend wurden die Litterbags in Sporensuspensionen von M. ochracea WG inokuliert und im Boden vergraben. 
Im Versuchsjahr 2007/2008 wurden die Litterbags in einer Sporensuspension von M. ochracea WG mit einer Sporendichte von 8 x $10^{6}$ Sporen/ml (3g M. ochracea WG pro Liter $\mathrm{H}_{2} \mathrm{O}$ ) bzw. Wasser tauchinokuliert und am 8. Okt. 2007 in $10 \mathrm{~cm}$ und $20 \mathrm{~cm}$ Bodentiefe in der „Miniplotanlage“, Institutsgarten Göttingen-Weende vergraben. Die ersten Litterbags wurden bereits 5 Wochen später am 13. Nov. 2007 geborgen. Die übrigen Litterbags wurden am 16. Mai 2008 geborgen.

Im Versuchsjahr 2008/2009 wurden die Versuche an den Standorten „Miniplotanlage“ und „Große Breite“ Göttingen-Weende durchgeführt. Es wurden Litterbags mit stark von $V$. longisporum befallenem Rapsstroh befüllte und in Sporensuspension von M. ochracea WG mit Sporendichten von $8 \times 10^{4}$ und $8 \times 10^{6}$ Sporen/ml oder in Wasser tauchinokuliert. Anders als im Versuchsjahr 2007/2008 wurden die Litterbags nach erfolgter Inokulation für eine Woche bei $20^{\circ} \mathrm{C}$ und einer Luftfeuchtigkeit von größer 90\% in Feuchteboxen im Dunkeln inkubiert bevor sie am 23. Sept. 2008 in $10 \mathrm{~cm}$ und 20 cm Bodentiefe vergraben wurden. Am 3. Juni 2009 wurden die Litterbags geborgen. Auf eine Beprobung im Herbst 2008 wurde an beiden Standorten verzichtet.

Anschließend wurde das Probenmaterial luftgetrocknet, von groben Erdanhaftungen befreit und bis zur weiteren Verarbeitung trocken gelagert. Eine mögliche Besiedlung der Rapsstängel mit M. ochracea wurde mittels qualitativer PCR-Analyse untersucht. Darüber hinaus wurde ein möglicher Abbau des Inokulums von $V$. longisporum auf dem Rapsstängelproben, die im Herbst 2007 geborgenen wurden, durch Quantifizieren des DNA-Gehaltes von V. longisporum mittels Real time PCR ermittelt.

Ein möglicher Abbau der Mikrosklerotien von V. longisporum durch $M$. ochracea wurde bei den im Frühsommer 2008 und 2009 geborgenen Proben durch einen Biotest untersucht, der im Gewächshaus durchgeführt wurde. Für die Untersuchung der im Herbst 2007 geborgenen Proben im Biotest stand nicht ausreichend Probenmaterial zur Verfügung. Nach dem Trocknen wurde das Rapsstroh fein vermahlen, je 1 g Probenmaterial in ein Standarderdengemisch in $10 \mathrm{~cm}$ Kunststofftöpfe eingemischt und Rapid cycling rapeseed (RCR) als Modellrapspflanze ausgesäät (vgl 2.11.1 Pflanzenanzucht, Wachstumsbedingungen). Es wurden pro Wiederholung jeder Behandlungsvariante drei technische Wiederholungen angesetzt, deren Messwerte für die Auswertung zusammengefasst wurden. Zusätzlich wurde als Negativkontrolle eine nicht inokulierte Wasserkontrolle angesetzt, die mit $1 \mathrm{~g}$ autoklaviertem und fein vermahlenen Rapsstroh versetzt wurde. Zur Ermittlung des Befalls der Modellrapspflanzen mit V. longisporum 
wurde in BBCH 65 der Befallswert (BW) bonitiert, in BBCH 75 die Pflanzenlänge (PFL) und in BBCH 80 die Sprosstrockenmasse (STM) bestimmt. Anschließend wurde durch Verrechnung der Daten mit der unbehandelten Wasserkontrolle die relative Planzenlänge (rPFL) und relative Sprosstrockenmasse (rSTM) in \% berechnet. Durch Vergleich von BW, rPFL und rSTM der mit M. ochracea WG behandelten Varianten zu den jeweiligen Kontrollen, konnten mögliche Unterschiede an infektiösen Inokulum von $V$. longisporum ermittelt, und somit ein möglicher Abbau des Inokulums von $V$. longisporum durch $M$. ochracea auf Rapsstängeln im Boden festgestellt werden.

\subsubsection{Reproduktion von M. ochracea auf Rapsstroh im Freiland}

Bei diesem Versuchsansatz wurde das Wachstum von M. ochracea auf Rapsstängeln unter Feldbedingungen untersucht. Befallsfreie Rapsstängel wurden mit Hilfe eines Laubhäckslers in 1-3 cm große Stücke zerkleinert und Strohabbausäcke (Litterbags) mit einer ca. 2 cm Schicht Häckselgut befüllt. Diese wurden in einer Sporensuspension von V. longisporum (Vl 43) (1 x $10^{6}$ Sporen/ml), einer Sporensuspension von M. ochracea $\left(1 \times 10^{6}\right.$ Sporen $\left./ \mathrm{ml}\right)$, einer Sporensuspension bestehend aus $V$. longisporum und M. ochracea $\left(1 \times 10^{6}\right.$ Sporen $/ \mathrm{ml}$ M. ochracea, $1 \times 10^{6}$ Sporen $/ \mathrm{ml} \mathrm{Vl} \mathrm{43)} \mathrm{oder} \mathrm{Wasser}$ tauchinokuliert. Anschließend wurden die Litterbags am 7. Oktober 2008 am Standort „Große Breite“ auf der Bodenoberfläche ausgebracht bzw. in $5 \mathrm{~cm}$ Bodentiefe vergraben. Nach acht Monaten wurden die Litterbags am 10. Juni 2009 geborgen, die Rapsstängel getrocknet, von groben Erdanhaftungen gesäubert und mit Hilfe eines Stereomikroskops auf eine Besiedlung mit Mikrosklerotien von V. longisporum und Pyknidien von M. ochracea untersucht. Darüber hinaus wurde die Besiedlung der Rapsstängel mit M. ochracea durch eine qualitative PCR-Analyse ermittelt.

\subsection{Feldversuche}

Ziel der Feldversuche war es das mykoparasitische Potential von $M$. ochracea unter Feldbedingungen zu untersuchen. Hierfür wurden am Standort Göttingen über zwei Jahre Fruchtfolgeversuche angelegt bei denen auf eine wendende Bodenbearbeitung verzichtet und je nach Situation nur eine Minimalbodenbearbeitung durchgeführt wurde. Ziel war es möglichst viele inokulumbelastete Ernterückstände an der Bodenoberfläche zu belassen, um den Inokulumabbau durch $M$. ochracea zu untersuchen. Ein möglicher Inokulumabbau wurde indirekt über visuelle Krankheitsbonitur an den 
Kulturpflanzen untersucht. Die Versuche wurden in Großparzellen angelegt um Auswirkungen durch Verschleppung von inokulumbelasteten und mit M. ochracea bewachsenen Ernterückständen durch Bodenbearbeitungsgeräte auf die Kernparzellen vernachlässigen zu können.

\subsubsection{Standorte und meteorologische Daten}

Die Feldversuche wurden in den Jahren 2007/2008 und 2008/2009 an den Standorten „Große Breite“ (Winterweizenmonokulturversuch) und „Große Lage“ (Winterrapsmonokulturversuch, Winterraps-Winterweizen-Fruchtfolgeversuch) der Versuchswirtschaft Rheinshof, der Universität Göttingen angelegt. Die Versuchsflächen liegen in der Talaue des Leinegrabens am Stadtrand von Göttingen zwischen den Ortsteilen Holtensen und Weende. Bei dem Bodentyp handelt es sich nach Klassifizierung der Reichsbodenschätzung um einen Lehmboden der Zustandsstufe 2 mit einer Ackerzahl von 89. Die Winterrapsversuche wurden auf dem Standort „Große Lage“ angelegt, da aufgrund einer engen Rapsfruchtfolge in den letzten Jahren und Inokulationsversuchen mit V. longisporum (2003/2004) ein homogenes Ausgangsinokulum mit einer Befallshäufigkeit von 74\% befallener Rapsstoppeln vorhanden war.

Angaben zum Witterungsverlauf während dem Versuchszeitraum (2007-2009) basieren auf meteorologischen Daten des Deutschen Wetterdienstes, Wetterstation Göttingen. Um den Wittersungsverlauf zum Zeitpunkt der Inokulationen mit M. ochracea zu beschreiben wurden die Tagesniederschlagsmengen (mm) und die Tagesbodendurchschnittstemperaturen $\left({ }^{\circ} \mathrm{C}\right)$ in $5 \mathrm{~cm}$ Bodentiefe für die Monate August- September und März-April in den Versuchsjahren 2007/2008 und 2008/2009 dargestellt.

\subsubsection{Versuchsaufbau}

Am Standort Göttingen wurden im Sommer 2007 drei Feldversuche für die Dauer von zwei Jahren mit Winterweizen-Monokulturanbau, Winterraps-Monokulturanbau und einer Winterweizen-Winterraps-Fruchtfolge angelegt. Die Versuche wurden als randomisierte Blockversuche mit einer Parzellengröße von 12 m x 15 m gestaltet.

Alle Versuche wurden mit 4 Behandlungsstufen von M. ochracea WG und 2 Kontrollvarianten angelegt. Die Behandlungsstufen umfassten eine $1 \mathrm{~kg} / \mathrm{ha}$ und eine $2 \mathrm{~kg} / \mathrm{ha}$ Herbstbehandlung mit M. ochracea WG, und eine 1 kg/ha und eine 2 kg/ha Herbst- und Frühjahrsbehandlung mit M. ochracea WG. Als Kontrollvarianten wurden eine 
unbehandelte Kontrollvariante und eine Fungizidvariante mit praxisüblichen Fungizidbehandlungen angelegt, die sich an der Befallssituation orientierten. Alle Versuchsvarianten wurden vierfach wiederholt, wodurch jeder Versuch aus 24 Versuchsparzellen bestand.

\subsubsection{Feldinokulation mit M. ochracea WG}

Bei der Vorbereitung der Versuchsparzellen wurde auf ein feinkrümeliges Saatbeet mit einem hohen Anteil von Ernterückständen an der Bodenoberfläche geachtet. Bei Bedarf wurden die Versuchsparzellen erneut mit Kreiselegge und Walze bearbeitet. Darüber hinaus erfolgten die Behandlungen mit M. ochracea WG nur bei möglichst optimalen Bodenfeuchtigkeitsbedingungen und geringer Sonneneinstrahlung in den Morgen- oder Abendstunden. Die Spritzapplikation von M. ochracea WG auf die Versuchsparzellen wurde mit praxisüblicher Spritztechnik durchgeführt. Hierfür wurde die Pflanzenschutzspritze gründlich gereinigt, um sie vor allem von Fungizidrückständen aber auch sonstigen Chemikalien zu befreien, die die Keimfähigkeit und somit die Wirkung der Sporen von M. ochracea negativ beeinflussen könnten. Vor dem Befüllen der Pflanzenschutzspritze wurde M. ochracea WG in warmem Wasser $\left(25^{\circ} \mathrm{C}\right)$ suspendiert und in der Pflanzenschutzspritze mit Wasser auf das Endvolumen aufgefüllt. Die Applikation von M. ochracea WG erfolgte mit einer Wasseraufwandmenge von 300 l/ha. Zur Applikation von $1 \mathrm{~kg} / \mathrm{ha}$ M. ochracea WG wurden die Parzellen einmal gespritzt. Zur Behandlung der Versuchsvarianten mit 2 kg/ha M. ochracea WG wurden die Parzellen doppelt behandelt. Nach der Spritzapplikation wurden die Versuchsparzellen umgehend mit der Kreiselegge bearbeitet, um einen Kontakt der Sporen von M. ochracea mit feuchtem Boden sicher zu stellen. Im Gegensatz zur Herbstbehandlung konnte nach der Frühjahrsbehandlung keine Bodenbearbeitung durchgeführt werden. Die Frühjahrsbehandlung mit M. ochracea WG wurde zu Vegetationsbeginn in den feuchten Bestand durchgeführt.

\subsubsection{Aussaat und Bestandespflege}

Im Herbst 2007 wurden die Parzellen eingemessen und die Ecken der Parzellen mit Dauermagneten in $30 \mathrm{~cm}$ Bodentiefe markiert. Nach der Spritzapplikation von M .ochracea WG und der Einarbeitung erfolgte im Sommer/Herbst 2007 und 2008 die großflächige Aussaat von Winterraps und Winterweizen. Für die Versuche mit Winter- 
raps wurde in beiden Jahren die Sorte Trabant verwendet. Diese weist eine mittlere Anfälligkeit gegenüber $P$. lingam auf. Über die Anfälligkeit gegenüber $V$. longisporum können aufgrund fehlender Befallseinstufungen in der beschreibenden Sortenliste keine Angaben gemacht werden. Für die Versuche mit Winterweizen wurde in beiden Jahren die Sorte Paroli verwendet. Diese weist eine mittlere bis hohe Anfälligkeit gegenüber S. tritici, D. tritici-repentis und Ährenfusarium auf (Bundessortenamt, 2008).

Die Insektizid-, Herbizid- und Düngungsmaßnahmen wurden großflächig nach guter fachlicher Praxis in allen Versuchsparzellen einheitlich durchgeführt.

Krankheitsbonituren wurden in den Winterweizen- und Winterraps- Monokulturversuchen in den Versuchsjahren 2007/2008 und 2008/2009 durchgeführt. Bei dem Winterraps-Winterweizen-Fruchtfolgeversuch wurde nur 2008/2009 eine Krankheitsbonitur an Winterraps durchgeführt. Der Parzellenertrag sollte bei dem Winterweizenund Winterraps- Monokulturversuchen jährlich erfasst werden. Eine Ertragserfassung im Winterraps Monokulturversuch konnte im Sommer 2008 aufgrund von Hagelschlag nicht durchgeführt werden. Bei dem Winterraps- Winterweizen- Fruchtfolgeversuch wurde der Parzellenertrag im Winterraps nur zur Ernte 2009 erfasst.

Genaue Behandlungstermine und Behandlungsmaßnahmen sind den Schlagkarteidaten zu entnehmen (Tab. 1, 2, 3, 4, 5, 6 Anhang).

\subsection{Auswertung und Statistik}

Die Auswertung und die graphische Darstellung der Versuchsergebnisse erfolgte mit den Programmen Excel 2003 und Sigma Plot 8.0. Die statistische Auswertung erfolgte mit dem Statistikprogramm XLSTAT-Pro 7.5 (Addinsoft, SARL). In einer Varianzanalyse wurden die Mittelwerte und die Standardfehler analysiert. Nach der Verrechnung der Daten wurde ein multipler Mittelwertvergleich mit dem Fisher Least Significant Difference Test (LSD-Test) durchgeführt. Aufgrund des geringen Stichprobenumfangs $(n=4)$ konnte eine Normalverteilung der Daten nicht immer gewährleistet werden, weshalb die statistische Auswertung mancher Versuche Approximationen darstellt. Falls in den Abbildungs- und Tabellenbeschriftungen nicht anders erwähnt, kennzeichnen unterschiedliche Buchstaben statistische Unterschiede bei einer Irrtumswahrscheinlichkeit von $5 \%(\mathrm{p} \leq 0,05)$. 


\section{Ergebnisse}

\subsection{Laboruntersuchungen}

Bei den Laboruntersuchungen wurde das mykoparasitische Potential von M. ochracea auf Mikrosklerotien von Verticillium spp. untersucht. Dabei wurden auch Mikrosklerotien von $V$. dahliae mit in die Untersuchungen einbezogen, obwohl sich diese Verticillium-Art nicht im Spross von Brassica napus ausbreiten kann (Eynck et al., 2007). Darüber hinaus wurde die inokulumreduzierende Wirkung von M. ochracea auf Perithezien von F. graminearum (G. zeae) in vitro untersucht. Das mykoparasitische Potential von $M$. ochracea auf die Fruchtkörper der heterothallischen Pathogene P. lingam (L. maculans), S. tritici (M. graminicola) und D. tritici-repentis (P. triticirepentis) konnte aufgrund fehlender Methoden zur Massenproduktion von Pseudothezien in vitro nicht untersucht werden.

\subsubsection{Hemmung des radialen Myzelwachstums durch M. ochracea}

Um eine mögliche antagonistische Wirkung von $M$. ochracea auf das Myzelwachstum von $V$. longisporum, $P$. lingam, D. tritici-repentis und F. graminearum zu untersuchen wurde ein etablierter Antagonismustest auf den Nährmedien PDA, V8 und OA durchgeführt (vgl. 2.9.1). S. tritici konnte aufgrund von fehlendem radialen Myzelwachstum nicht mit in die Untersuchung einbezogen werden.

Tab. 14: Hemmung des radialen Myzelwachstums (\%) der Rapspathogene $V$. longisporum, P. lingam (14 dpi) und der Getreidepathogene D. triticirepentis, F. graminearum (9 dpi) durch $M$. ochracea; Dargestellt sind Mittelwert und Standardabweichung $(\mathrm{Mw} \pm$ Stabw); untersucht nach Fokkema (1973); $(\mathrm{n}=10)$.

\begin{tabular}{ccccc}
\hline & V. longisporum & P. lingam & D. tritici-repentis & F. graminearum \\
& $14 \mathrm{dpi}$ & $14 \mathrm{dpi}$ & $9 \mathrm{dpi}$ & $9 \mathrm{dpi}$ \\
\hline PDA & $20,1 \pm 14,3$ & --- & $3,4 \pm 6,0$ & $16,4 \pm 20,4$ \\
V8 & $23,9 \pm 15,3$ & $26,6 \pm 11,5$ & $12,9 \pm 13,1$ & $6,0 \pm 6,6$ \\
OA & $29,2 \pm 10,5$ & $19,1 \pm 23,4$ & $9,1 \pm 14,7$ & $14,3 \pm 12,9$ \\
\hline
\end{tabular}

Die Hemmung des radialen Myzelwachstums der Rapspathogene V. longisporum und $P$. lingam durch $M$. ochracea wurde 14 dpi gemessen. Für $V$. longisporum wurde eine 
Hemmung des radialen Myzelwachstums durch M. ochracea zwischen 20,1 und 29,2\% in Abhängigkeit von dem verwendeten Nährmedium gemessen. Auch bei P. lingam wurde eine Hemmung des radialen Myzelwachstums durch M. ochracea zwischen 19,1 und 26,6\% ermittelt. Aufgrund atypischen Wachstums von P. lingam auf PDA wurden diese Messwerte nicht zur Auswertung herangezogen (Tab. 14).

Die Hemmung des radialen Myzelwachstums der Getreidepathogene D. tritici-repentis und F. graminearum durch $M$. ochracea wurde 9 dpi gemessen. Für $D$. tritici-repentis wurde eine Hemmung des radialen Myzelwachstums zwischen 3,4 und 12,9\%, und bei F. graminearum zwischen 6,0 und 16,4\% ermittelt (Tab. 14).

Die dargestellten Ergebnisse zeigen eine deutliche Hemmwirkung von M. ochracea auf das Myzelwachstums der getesteten Raps- und Getreidepathogene. Die Messdaten unterlagen sehr hohen Standardabweichungen und die Hemmung des radialen Myzelwachstums durch $M$. ochracea war stark abhängig vom verwendeten Nährmedium. Eine Bildung von Hemmzonen zwischen M. ochracea und den Testisolaten wurde bei keinem der getesteten Pathogene beobachtet.

\subsubsection{Mikrosklerotienkeimung und Mikrosklerotienbildung bei Verticillium spp. in Abhängigkeit von der Temperatur}

Bei dem dargestellten Versuch wurde das Keimverhalten der Mikrosklerotien von V. longisporum (Vl 43) und V. dahliae (Vd 73) in vitro bei verschiedenen Inkubationstemperaturen im Dunkeln untersucht.

Die schnellste Keimung der Mikrosklerotien mit hohen Keimraten wurde für V. dahliae und $V$. longisporum bei $24^{\circ} \mathrm{C}$ beobachtet. Dabei wurden 2 und 3 dpi bei $V$. dahliae signifikant höhere Keimraten als bei $V$. longisporum ermittelt. Es kam auch bei $16^{\circ} \mathrm{C}$ und $20^{\circ} \mathrm{C} \mathrm{zu}$ einer schnellen Keimung der Mikrosklerotien von $V$. longisporum und V. dahliae. Es wurde bei $20^{\circ} \mathrm{C} \mathrm{2,} \mathrm{3,} 4$ dpi und bei $16^{\circ} \mathrm{C} 2,3,4$ und 5 dpi signifikant höhere Keimraten der Mikrosklerotien von V. dahliae im Vergleich zu Mikrosklerotien von $V$. longisporum bonitiert. Bei $8^{\circ} \mathrm{C}$ wurden 3, 4, 5, 6, 7, 9 dpi und bei $12^{\circ} \mathrm{C} 2,3,4,5$, 6, 7 und 9 dpi signifikant höhere Keimraten bei Mikrosklerotien von V. dahliae im Vergleich zu Mikrosklerotien von V. longisporum bonitiert. Bei einer Inkubationstemperatur von $28^{\circ} \mathrm{C}$ zeigten Mikrosklerotien von $V$. dahliae ein ähnliches Keimverhalten wie bei $16^{\circ} \mathrm{C}$ Inkubationstemperatur, und es wurden bereits 4 dpi eine Keim- 
rate von $98 \%$ ermittelt. Die Mikrosklerotien von $V$. longisporum keimten bei $28^{\circ} \mathrm{C}$ deutlich langsamer und es waren 11 dpi 77\% der Mikrosklerotien gekeimt (Abb. 3).

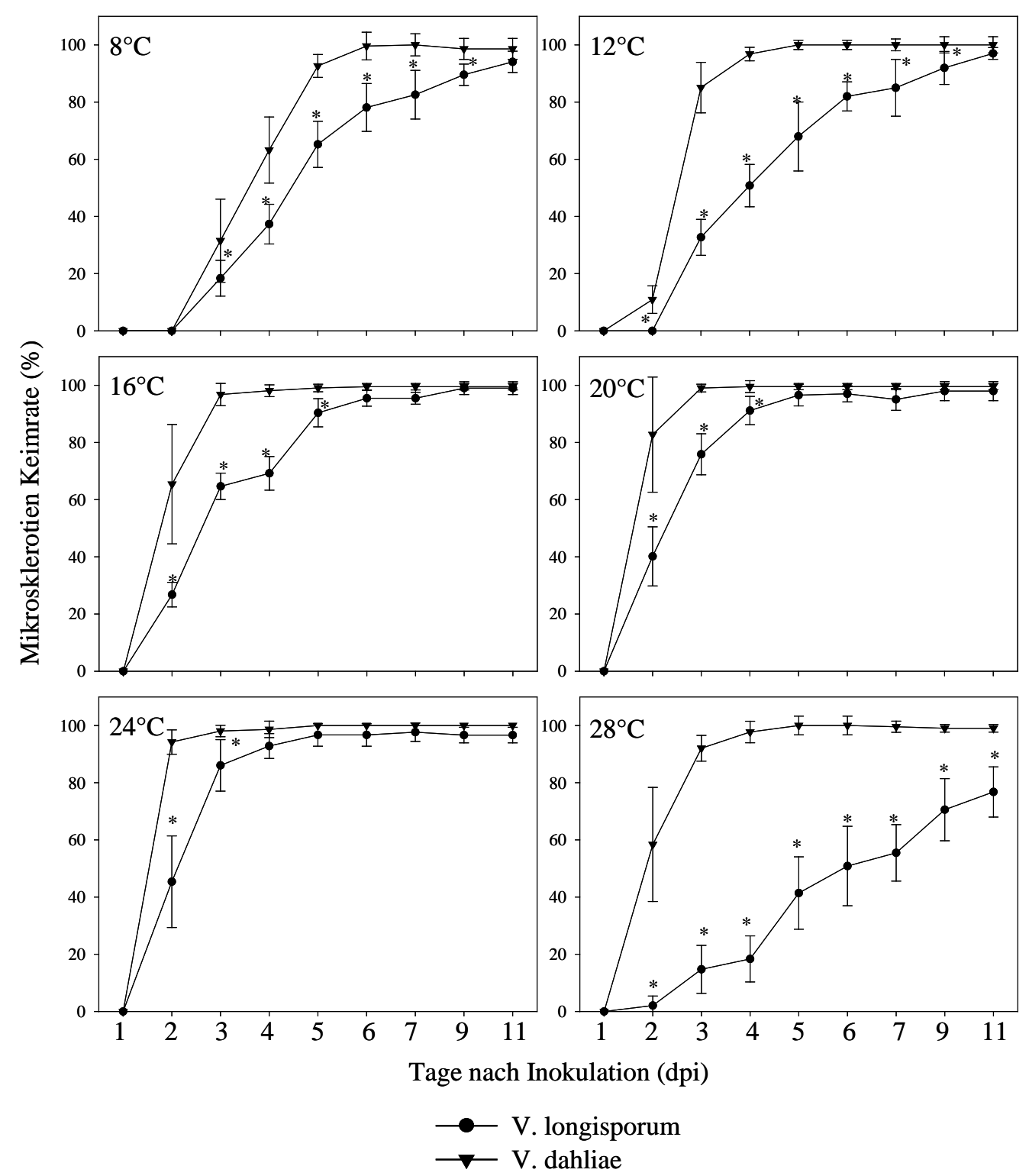

Abb. 3: Mikrosklerotienkeimung von $V$. longisporum und $V$. dahliae. Dargestellt ist die Mikrosklerotienkeimrate (\%) des Isolates Vl 43 von V. longisporum und des Isolates Vd 73 von $V$. dahliae 1, 2, 3, 4, 5, 6, 7, 9 und 11 dpi bei Inkubationstemperaturen von $8,12,16,20,24$ und $28^{\circ} \mathrm{C}$ auf PDA. * signifikant unterschiedliche Keimraten von $V$. longisporum und $V$. dahliae zum jeweiligen Boniturtermin; $n=5$; Fisher-Test (LSD) $\mathrm{p} \leq 0,05$.

Darüber hinaus wurde bei Temperaturen von $4{ }^{\circ} \mathrm{C}$ und $32^{\circ} \mathrm{C}$ eine Mikrosklerotienkeimung beobachtet. Bei $4^{\circ} \mathrm{C}$ lag die Keimrate der Mikrosklerotien von V. dahliae 11 dpi bei $49 \%$, und somit signifikant über der von $V$. longisporum. Bei $32^{\circ} \mathrm{C}$ waren $11 \mathrm{dpi}$ 78\% der Mikrosklerotien von $V$.dahliae und 5\% der Mikrosklerotien von 
V. longisporum gekeimt. Es wurde 3, 4, 5, 6, 7, 9 und 11 dpi signifikant höhere Keimraten bei den Mikrosklerotien von $V$. dahliae im Vergleich zu denen von V. longisporum bonitiert(Tab. 8 Anhang).

Neben der Mikrosklerotienkeimung wurde die Mikrosklerotienneubildung der gekeimten Mikrosklerotien erfasst. Dabei lag die optimale Temperatur für die Mikrosklerotienneubildung von $V$. longisporum und $V$. dahliae bei $24^{\circ} \mathrm{C}$, also ähnlich der Temperatur der Mikrosklerotienkeimung. Für V. longisporum wurde eine Mikrosklerotienneubildung bei 24, 20, 16 und $12^{\circ} \mathrm{C}$ beobachtet, wobei diese bei $12^{\circ} \mathrm{C}$ erst 11 dpi ermittelt wurde. Es wurde eine Mikrosklerotienneubildung bei V. dahliae über ein weiteres Temperaturspektrum bonitiert. Gekeimte Mikrosklerotien zeigten bei 28, 24, 20, 16, 12, und $8^{\circ} \mathrm{C}$ eine deutliche und teilweise rasante Mikrosklerotienneubildung (Tab. 9 Anhang).

\subsubsection{Keimhemmende Wirkung von M. ochracea auf Mikrosklerotien von Verticillium spp.}

In den folgenden Untersuchungen wurde die mykoparasitische Wirkung von $M$. ochracea auf Mikrosklerotien von $V$. longisporum und $V$. dahliae in vitro untersucht.

\subsubsection{Einfluss der Temperatur}

Bei diesem Versuchsansatz wurde mittels Filterplättchentest die keimhemmende Wirkung von $M$. ochracea $\left(1 \times 10^{6}\right.$ Sporen $/ \mathrm{ml}$ ) auf Mikrosklerotien von $V$. longisporum in Abhängigkeit von der Inkubationstemperatur $\left(4,8,12,16,20,24^{\circ} \mathrm{C}\right)$ und der Inkubationsdauer (6, 10 Tage) untersucht.

Als Kontrolle wurde die Mikrosklerotienkeimung ohne $M$. ochracea bei $12^{\circ} \mathrm{C}$ und $20^{\circ} \mathrm{C}$ Inkubationstemperatur während 6 und 10 Tagen Inkubationsdauer überprüft. Dabei lag die Mikrosklerotienkeimung in allen Kontrollvarianten über 90\% (Daten nicht dargestellt).

Sechs Tage nach Inokulation der Mikrosklerotien mit M. ochracea wurden bei Inkubationstemperaturen von 24, 20 und $16^{\circ} \mathrm{C}$ eine signifikant höhere Mortalität der Mikrosklerotien im Vergleich zu Inkubationstemperaturen von 12 , 8, und $4^{\circ} \mathrm{C}$ ermittelt. Verglichen mit der Inkubationstemperatur von $4^{\circ} \mathrm{C}$ wurde bei $8^{\circ} \mathrm{C}$ eine signifikant höhere und bei $12^{\circ} \mathrm{C}$ eine tendenziell höhere Mortalität festgestellt (Abb. 4 links). 
Nach 10 Tagen Inkubationsdauer wurden bei den Mikrosklerotien bei Inkubationstemperaturen von 24,20 und $16^{\circ} \mathrm{C}$ eine signifikant höhere Mortalität verglichen mit 12 , 8 und $4^{\circ} \mathrm{C}$ Inkubationstemperatur bonitiert. Bei niedrigen Inkubationstemperaturen nahm die Mortalität der Mikrosklerotien mit ansteigender Inkubationstemperatur $\left(4^{\circ} \mathrm{C}-\right.$ $12^{\circ} \mathrm{C}$ ) signifikant zu (Abb. 4 links).

Bei diesem Versuch kam es zu einem vermehrten Auftreten partiell gekeimter Mikrosklerotien bei niedrigen Inkubationstemperaturen. Dieser Anteil nahm mit ansteigenden Inkubationstemperaturen ab (Abb. 4 rechts).
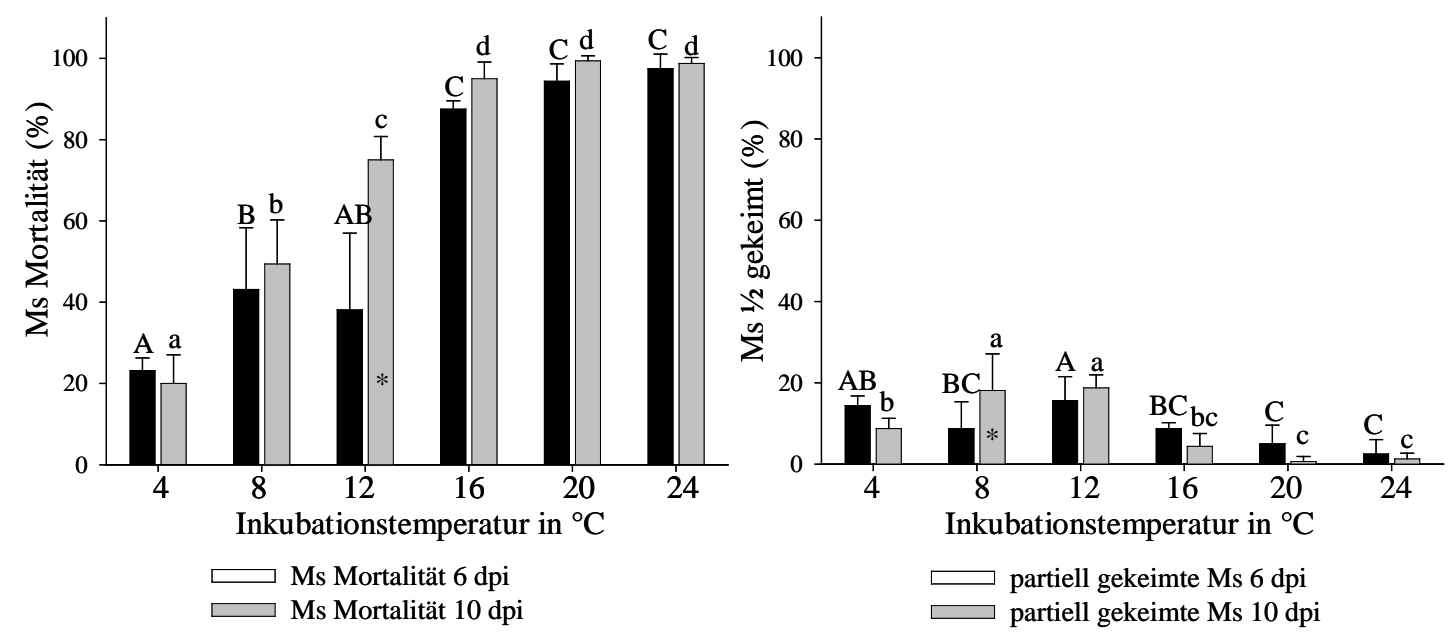

Abb. 4: Keimhemmende Wirkung von M. ochracea auf Mikroskelrotien (Ms) von V. longisporum im Filterplättchentest. Dargestellt sind Mortalität (\%) der Mikrosklerotien (links) und der Anteil partiell (1/2) gekeimter Mikrosklerotien (\%) (rechts) bei unterschiedlichen Inkubationstemperaturen $\left(4-24^{\circ} \mathrm{C}\right)$ und unterschiedlichen Inkubationszeiten (6, 10 Tage) nach Inokulation mit M. ochracea ( 1 x $10^{6}$ Sporen/ml). Unterschiedliche Buchstaben kennzeichnen signifikante Unterschiede zwischen den Inkubationstemperaturen; * signifikanter Unterschied zwischen den Inkubationszeiten; $\mathrm{n}=4$; Fisher-Test (LSD) $\mathrm{p} \leq 0,05$.

Bei Inkubationstemperaturen von 8, 16, 20 und $24^{\circ} \mathrm{C}$ wurde eine tendenziell höhere Mortalität der Mikrosklerotien nach 10 Tagen verglichen mit 6 Tagen Inkubationsdauer bonitiert. Signifikante Unterschiede traten nur bei einer Inkubationstemperatur von $12^{\circ} \mathrm{C}$ auf (Abb. 4 links).

\subsubsection{Einfluss der Sporendichte von $M$. ochracea und der Inkubationsdauer}

Bei diesem Versuchsansatz wurde mittels Filterplättchentest die keimhemmende Wirkung von M. ochracea auf Mikrosklerotien von V. longisporum in Abhängigkeit 
von der Inkubationsdauer (6, 8, 10 Tage) und der Sporendichte von M. ochracea (1 x $10^{4}, 1 \times 10^{6}$ Sporen/ml) untersucht.

In der Wasserkontrolle wurde eine Mikrosklerotienkeimung von größer 95\% ermittelt. Durch Behandlung der Mikrosklerotien mit einer Sporensuspension von M. ochracea mit $1 \times 10^{6}$ Sporen/ml wurden die Mikrosklerotien bereits nach 6 Tagen vollständig in ihrer Keimung gehemmt. Für die Inkubationsdauern von 6, 8 und 10 Tagen wurde somit eine Mortalität der Mikrosklerotien von 100\% berechnet (Abb. 5).

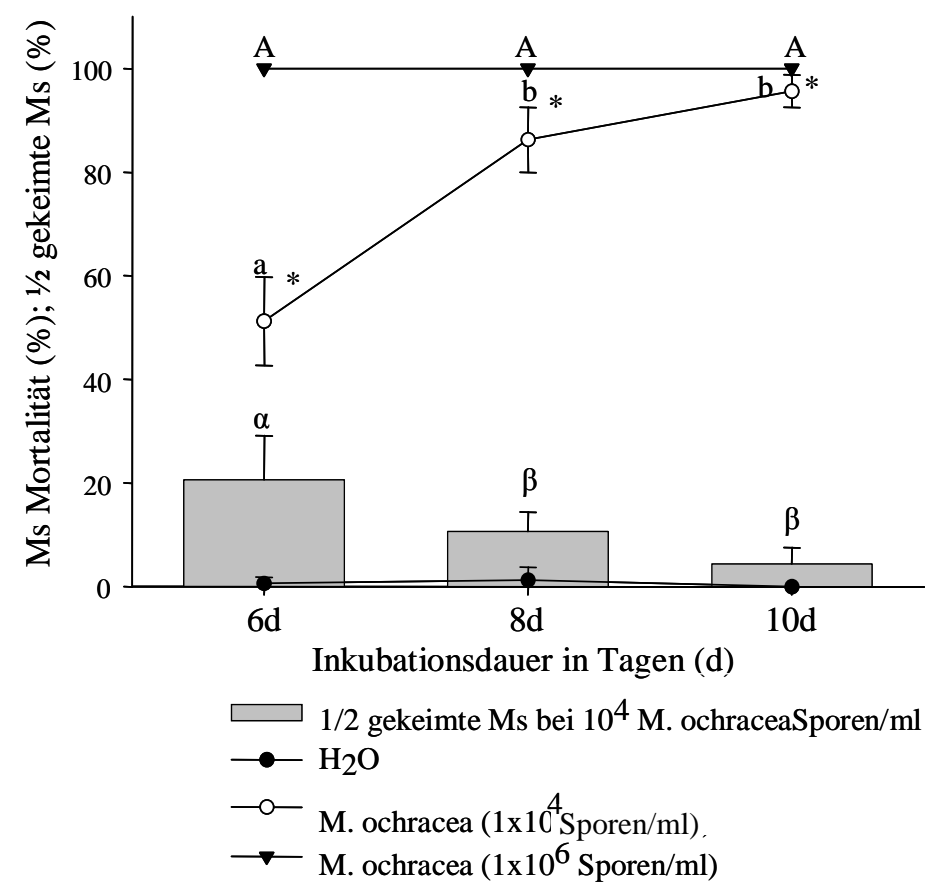

Abb. 5: Keimhemmende Wirkung von M. ochracea auf Mikrosklerotien (Ms) von $V$. longisporum in Abhängigkeit von der Sporendichte von M. ochracea $\left(1 \times 10^{4}\right.$, $1 \times 10^{6}$ Sporen/ml) und der Inkubationsdauer (6, 8, $10 \mathrm{~d}$ ) beim Filterplättchentest. Dargestellt sind die Mortalität der Mikrosklerotien (\%) und die partiell (1/2) gekeimten Mikrosklerotien bei $20^{\circ} \mathrm{C}$ Inkubationstemperatur und Dunkelheit. * Signifikant unterschiedliche Mikrosklerotienmortalitäten zwischen den Inokulationsstufen zu einem Inkubationszeitpunkt; unterschiedliche Buchstaben markieren den signifikanten Unterschied einer Sporendichte zwischen den Inkubationszeitpunkten; n=4; Fisher-Test (LSD) $\mathrm{p} \leq 0,05$.

Durch Behandlung der Mikrosklerotien mit einer Sporensuspension von M. ochracea mit $1 \times 10^{4}$ Sporen/ml wurde nach 6 Tagen Inkubation eine Mortalität von 51\% bestimmt. Diese stieg mit Verlängerung der Inkubationsdauer signifikant an, bis schließlich nach 10 Tagen 95\% der Mikrosklerotien nicht mehr keimten. Darüber 
hinaus trat nach 6 Tagen ein signifikant höherer Anteil partiell gekeimter Mikrosklerotien auf verglichen mit der Inkubationsdauer von 8 und 10 Tagen.

Durch Behandlung der Mikrosklerotien mit hoch konzentrierter Sporensuspension von M. ochracea ( 1 x $10^{6}$ Sporen/ml) wurde zu jedem Boniturtermin eine signifikant höhere Mortalität der Mikrosklerotien im Vergleich zur niedrigen Inokulationsstufe $\left(1 \times 10^{4}\right.$ Sporen $/ \mathrm{ml}$ ) festgestellt. Dieser Unterschied verringerte sich mit zunehmender Inkubationsdauer (Abb. 5).

\subsubsection{Einfluss von Licht}

In diesem Versuchsansatz wurde mittels Filterplättchentest die Mykoparasitierung der Mikrosklerotien von $V$. longisporum durch M. ochracea in Abhängigkeit vom Licht untersucht. Hierfür wurden Mikrosklerotien mit einer Sporensuspension von M. ochracea $\left(1 \times 10^{5}\right.$ Sporen/ml) beimpft und für 6 Tage bei $16 \mathrm{~h}$ Licht und $8 \mathrm{~h}$ Dunkelheit bzw. $24 \mathrm{~h}$ Dunkelheit bei $20^{\circ} \mathrm{C}$ inkubiert. Die Überprüfung der Mikrosklerotienkeimung auf V8 Nährmedium erfolgte bei beiden Varianten im Dunkeln bei $20^{\circ} \mathrm{C}$.

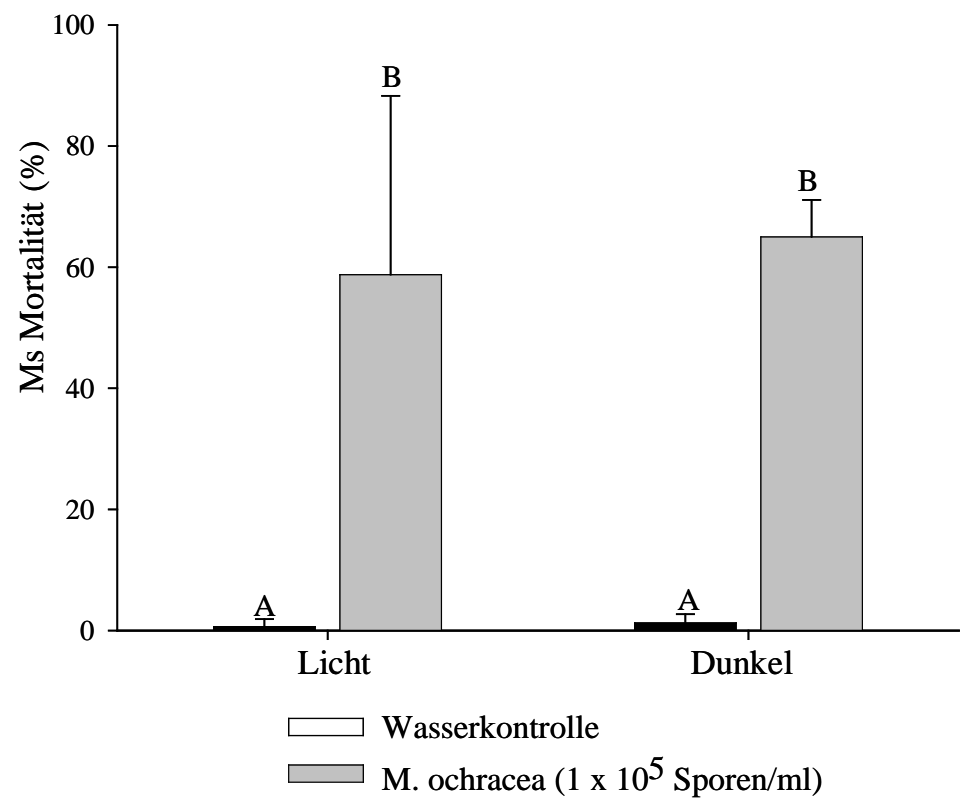

Abb. 6: Keimhemmende Wirkung von M. ochracea auf Mikrosklerotien (Ms) von V. longisporum im Filterplättchentest. Dargestellt sind die Mortaltitätsraten (\%) bei Licht (16h Licht, 8h Dunkelheit) und $24 \mathrm{~h}$ Dunkelheit 6 dpi mit $M$. ochracea $\left(1 \times 10^{5}\right.$ Sporen/ml) oder $\mathrm{H}_{2} \mathrm{O}$ und einer Inkubationstemperatur von $20^{\circ} \mathrm{C} ; \mathrm{n}=4$; Fisher-Test (LSD); $\mathrm{p} \leq 0,05$. 
In den Wasserkontrollen wurde eine Mikrosklerotienkeimung von über 95\% ermittelt. Im Vergleich zu den belichteten Varianten wurde unter Lichtausschluss eine tendenziell höhere Mortalitästrate von Mikrosklerotien festgestellt. Diese war statistisch nicht abzusichern, wodurch ein Einfluss der Belichtung auf das mykoparasitische Potential von M. ochracea weitgehend ausgeschlossen werden kann (Abb. 6).

\subsubsection{Einfluss des pH-Werts}

In diesem Versuchsansatz wurde mittels Filterplättchentest die keimhemmende Wirkung von $M$. ochracea $\left(1 \times 10^{4}\right.$ Sporen $/ \mathrm{ml}$ ) auf Mikrosklerotien von $V$. longisporum bei unterschiedlichen $\mathrm{pH}$-Werten (4,5; 5,5; 6,5 und 7,5) und einer Inkubationsdauer von 10 Tagen untersucht. Die Überprüfung der Vitalität der Mikrosklerotien erfolgte pH unabhängig auf V8 Medium.

Bei den Wasserkontrollen wurde eine Keimung der Mikrosklerotien von über 95\% ermittelt. Diese war unabhängig vom eingestellten $\mathrm{pH}-$ Wert. Mit ansteigendem $\mathrm{pH}$ Wert verbesserte sich die keimhemmende Wirkung von M. ochracea auf die Mikrosklerotien von $V$. longisporum.

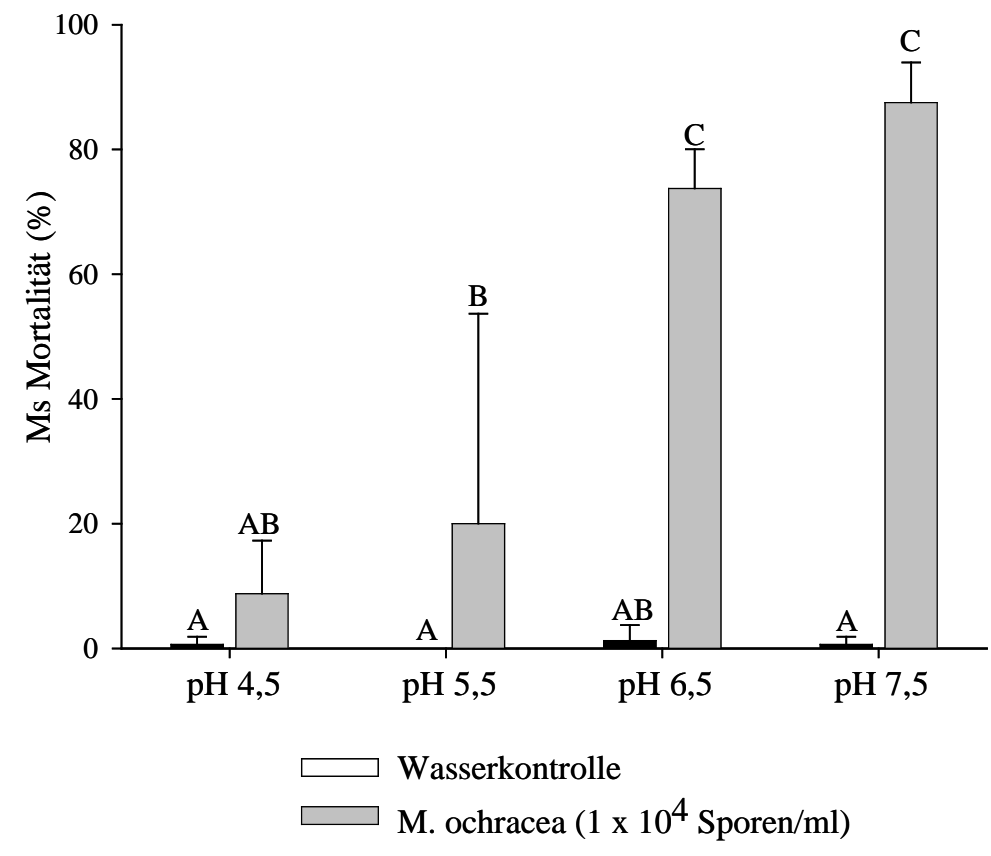

Abb. 7: Keimhemmende Wirkung von $M$. ochracea auf Mikrosklerotien von V. longisporum in Abhängigkeit vom pH-Wert im Filterplättchentest. Dargestellt ist die Mortalität (\%) 10 dpi. Inokulation mit M. ochracea (1x10 Sporen/ml) oder $\mathrm{H}_{2} \mathrm{O}$ und Inkubation im Dunkeln; $\mathrm{n}=4$; Fisher-Test (LSD); $\mathrm{p} \leq 0,05$. 
Bei pH-Werten von 7,5 und 6,5 wurden im Vergleich zu pH-Werten von 5,5 und 4,5 signifikant höhere Mortalitäten von Mikrosklerotien bonitiert. Tendenzielle Unterschiede waren auch zwischen den $\mathrm{pH}$-Werten 7,5 und 6,5 und zwischen 5,5 und 4,5 zu beobachten (Abb. 7).

\subsubsection{Bedeutung der Verticillium-Art und der Inkubationsdauer}

Bei diesem Versuchsansatz wurde mittels Filterplättchentest die keimhemmende Wirkung von M. ochracea auf Mikrosklerotien von $V$. longisporum und $V$. dahliae in Abhängigkeit von der Inkubationsdauer (6, 12, 18, 24 Tage) untersucht. Bei den Kontrollvarianten von V. longisporum und $V$. dahliae (nicht dargestellt) wurde eine Mikrosklerotienkeimung von über 95\% ermittelt.

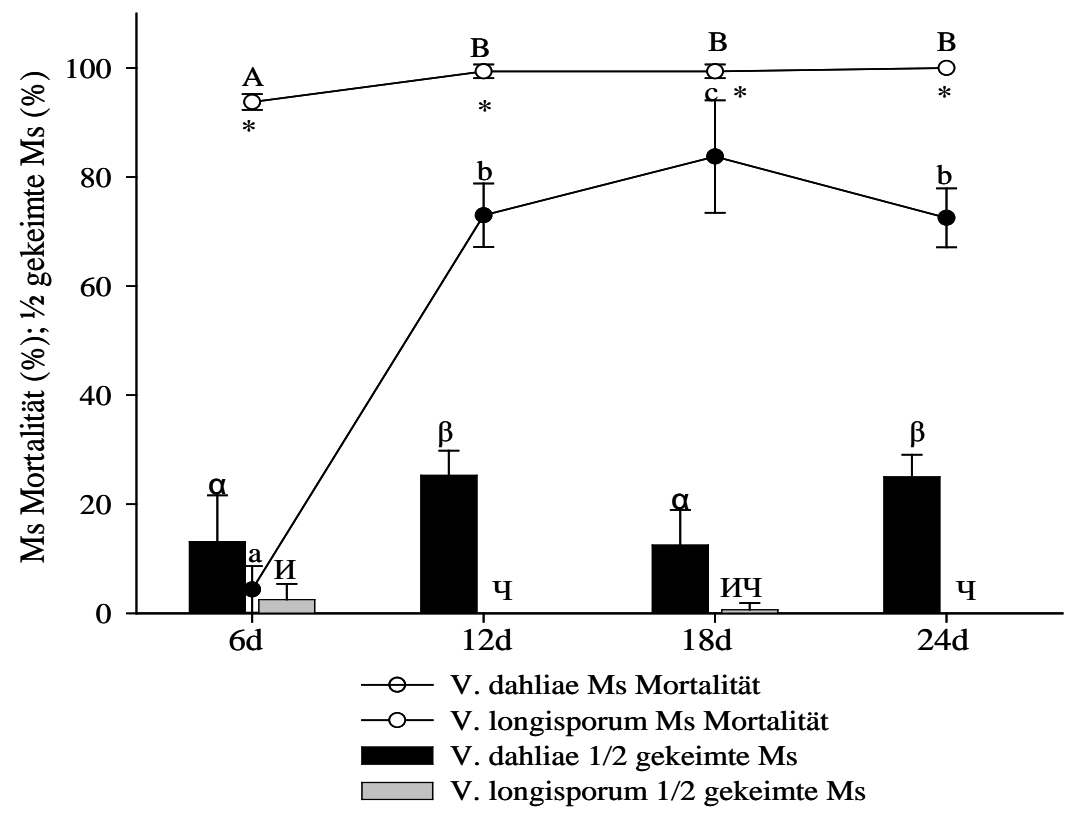

Abb. 8: Keimhemmende Wirkung von $M$. ochracea auf Mikrosklerotien (Ms) von $V$. longisporum und $V$. dahliae beim Filterplättchentest. Dargestellt ist die Mortalität der Mikrosklerotien und die partiell (1/2) gekeimten Mikrosklerotien 6, 12, 18, 24 dpi mit M. ochracea $\left(1 \times 10^{6}\right.$ Sporen/ml) und Inkubation bei $20^{\circ} \mathrm{C}$ im Dunkeln; * signifikant unterschiedliche Mortalitäten von V. longisporum (Vl 43) und V. dahliae (Vd 73) zum jeweiligen Inkubationszeitpunkt; Unterschiedliche Buchstaben bedeuten signifikant unterschiedliche Mortalität der Mikrosklerotien oder partiell (1/2) gekeimte Mikrosklerotien von $V$. longisporum und $V$. dahliae zwischen den Inkubationszeitpunkten; $\mathrm{n}=4$; Fisher-Test (LSD); $\mathrm{p} \leq 0,05$. 
Für die Mikrosklerotien von V. longisporum wurde nach 12, 18 und 24 Tagen eine Mortalität von $100 \%$ bonitiert. Diese lagen signifikant über der Mortalität der Mikrosklerotien, welche nach 6 Tagen ermittelt wurde.

Für Mikrosklerotien von $V$.dahliae wurden nach 6 Tagen Inkubationsdauer eine Mortalität von durchschnittlich 4\% ermittelt. Durch Verlängerung der Inkubationszeiten auf 12 und 18 Tage wurde ein signifikanter Anstieg der Mortalität bonitiert wobei nach 18 Tagen ein Maximum mit 84\% nicht gekeimter Mikrosklerotien erreicht wurde. Im Vergleich zu 18 Tagen Inkubationsdauer wurde nach 24 Tagen eine signifikant geringere Mortalität bonitiert (Abb. 8).

Nach Behandlung mit M. ochracea wurde bei V.dahliae im Vergleich mit V. longisporum zu allen Boniturterminen ein höherer Anteil partiell gekeimter Mikrosklerotien ermittelt. Für V. dahliae wurde nach 12 und 24 Tagen ein signifikant höherer Anteil partiell gekeimter Mikrosklerotien, als nach 6 und 18 Tagen Inkubationsdauer detektiert. Für die Mikrosklerotien von V. longisporum wurde nach 6 Tagen Inkubationsdauer ein signifikant höherer Anteil partiell gekeimter Mikrosklerotien, als nach 12 und 24 Tagen Inkubationszeit bonitiert (Abb. 8).

\subsubsection{Interaktion zwischen $M$. ochracea und $V$. longisporum auf sterilen Rapsstängeln}

\subsubsection{Koinokulationsversuch mit M. ochracea und V. longisporum}

Bei diesem Versuchsansatz wurde die Inokulumproduktion von V. longisporum auf sterilen Rapsstängeln nach Koinokulation mit V. longisporum und M. ochracea untersucht. Als Kontrolle wurden sterile Rapsstängel mit einer Sporensuspension von $V$. longisporum oder $M$. ochracea inokuliert.

19 Tage nach der Inokulation steriler Rapsstängel mit einer Sporensuspension von V. longisporum wurde ein starker Besatz mit Mikrosklerotien auf diesen beobachtet. Nach Koinokulation von Rapsstängeln mit V. longisporum und M. ochracea wurde auf diesen eine vereinzelte Mikrosklerotienbildung durch $V$. longisporum sowie vereinzelte Pyknidienbildung durch M. ochracea sichtbar. Es kam auch auf Rapsstängeln, die mit M. ochracea inokuliert wurden, zu einer Bildung von Pyknidien.

Bei der Real-time PCR wurde bei den Rapsstängeln, die mit $V$. longisporum inokuliert waren, ein V. longisporum-DNA-Gehalt von 4,5 ng/mg Trockenmasse gemessen. Dieser 
lag signifikant über dem der mit V. longisporum und M. ochracea koinokulierten Rapsstängel, bei denen ein V. longisporum-DNA-Gehalt von 0,073 ng/mg Trockenmasse gemessen wurde. Darüber hinaus wurde auf den Rapsstängeln, die nur mit $V$. longisporum inokuliert wurden (26,7 x $10^{5}$ Sporen/ml und g Frischmasse), im Vergleich zu den Rapsstängeln die mit V. longisporum und M. ochracea koiniokuliert wurden (3,5 x $10^{5}$ Sporen/ml und g Frischmasse), eine signifikant höhere Sporendichte von $V$. longisporum gemessen (Abb. 9 links).
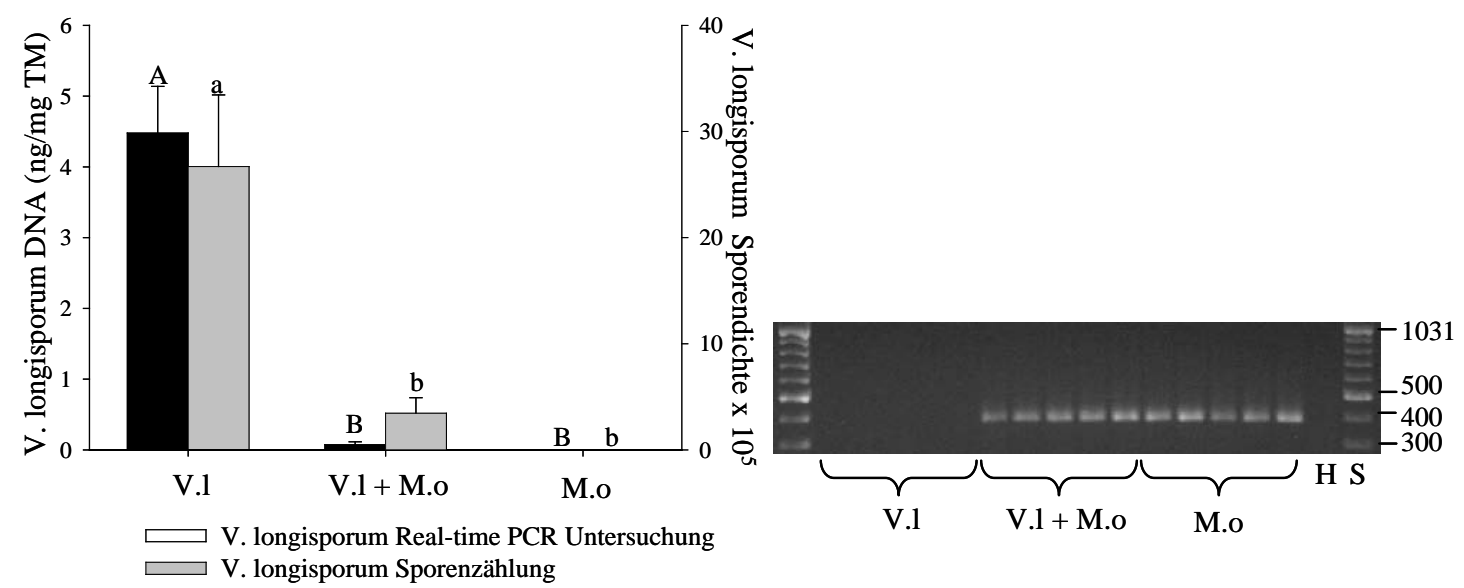

Abb. 9: Inokulumdichte von $V$. longisporum nach Inokulation steriler Rapsstängel mit $V$. longisporum $\left(1 \times 10^{6}\right.$ Sporen $\left./ \mathrm{ml}\right), V$. longisporum $+M$. ochracea $\left(1 \times 10^{6}+\right.$ $\left.1 \times 10^{6} \mathrm{Sporen} / \mathrm{ml}\right)$ und M. ochracea $\left(1 \times 10^{6} \mathrm{Sporen} / \mathrm{ml}\right)$. Links: Dargestellt ist der DNA-Gehalt von $V$. longisporum in Rapsstängeln und die Sporendichte von $V$. longisporum $\times 10^{5}$ Sporen/ml und g Rapsstängelfrischmasse 19 dpi und Inkubation bei $20^{\circ} \mathrm{C}$ auf WA im Dunkeln. Rechts: PCR Nachweis von $M$. ochracea bei den unterschiedlichen Behandlungsvarianten; $n=5$; FisherTest (LSD); $\mathrm{p} \leq 0,05$.

Auf den mit $M$. ochracea inokulierten Rapsstängeln wurden weder DNA noch Sporen von $V$. longisporum nachgewiesen (Abb. 9 links).

Bei PCR-Untersuchungen 19 dpi wurde DNA von M. ochracea auf Rapsstängeln nachgewiesen, die mit $V$. longisporum und $M$. ochracea koinokuliert oder mit M. ochracea alleine inokuliert waren (Abb. 9 rechts).

\subsubsection{Abbau von V. longisporum Mikrosklerotien auf Rapsstängeln nach Behandlung mit M. ochracea}

In diesem Versuchsansatz wurden sterile, unterschiedlich stark mit Mikrosklerotien von V. longisporum (Vl 43) bewachsene Rapsstängel mit M. ochracea inokuliert. Anschließend wurde der Inokulumabbau von V. longisporum durch M. ochracea mit Hilfe einer 
Real-time PCR-Untersuchung ermittelt und die Sporendichte von V.longisporum bestimmt.
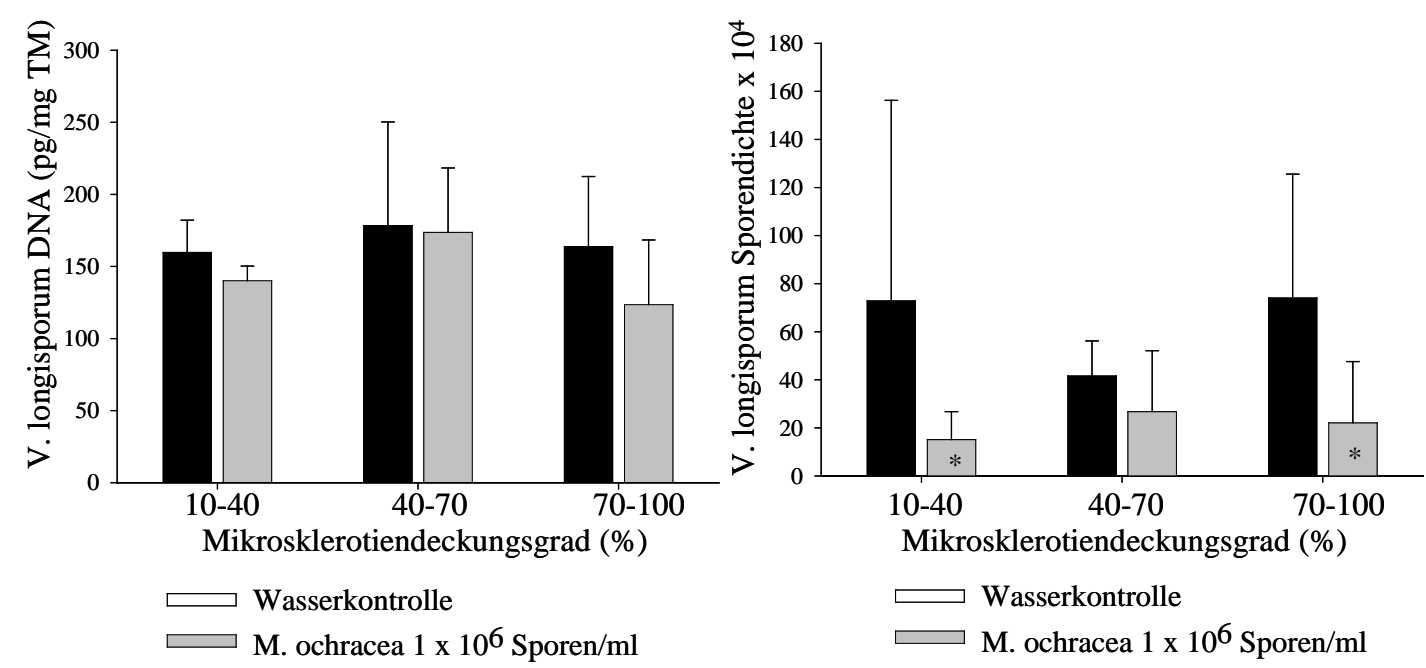

Abb. 10: Inokulumdichte von $V$. longisporum nach Inokulation von mit Mikrosklerotien bewachsenen Rapsstängeln mit M. ochracea. Rapsstängel mit unterschiedlichem Mikrosklerotiendeckungsgrad wurden mit M. ochracea (1 x $10^{6}$ Sporen/ml) inokuliert und für 19 Tage auf WA im Dunkeln inkubiert. Dargestellt ist der DNA-Gehalt von V. longisporum (links) und die Sporendichte von $V$. longisporum x $10^{4}$ pro g Rapsstängelfrischmasse (rechts) 19 dpi M. ochracea; * signifikante Unterschiede zwischen Wasserkontr. und M. ochracea Behandlung bei dem jeweiligen Mikrosklerotiendeckungsgrad; $\mathrm{n}=4$; Fisher-Test (LSD); $\leq \leq 0,05$.

Auf den Rapsstängeln, die mit M. ochracea behandelt waren wurde im Vergleich zu den unbehandelten Rapsstängeln, sowohl bei niedrigem (10-40\%), als auch bei hohem (70100\%) Mikrosklerotienbesatz durch Real-time PCR-Untersuchungen ein tendenziell geringerer DNA-Gehalt von V. longisporum gemessen. Bei mittlerem Mikrosklerotienbeatz (40-70\%) war eine solche Tendenz nicht zu beobachten. Ein Anstieg des DNAGehaltes von V.longisporum mit zunehmendem Bedeckungsgrad durch Mikrosklerotien wurde weder in der Wasserkontrolle, noch bei den mit M. ochracea inokulierten Rapsstängeln ermittelt (Abb. 10 links).

Darüber hinaus wurde die Sporendichte von $V$. longisporum auf den mit Mikrosklerotien bewachsenen Rapsstängeln bestimmt. Nach der Inokulation mit M. ochracea wurde sowohl auf den Rapsstängeln mit niedrigem (10-40\%), als auch mit hohem (70-100\%) Mikrosklerotiendeckungsgrad eine signifikant geringere Sporendichte ermittelt als bei den unbehandelten Rapsstängeln. Auch bei einem mittleren Mikrosklerotienbesatz (40-70\%) waren tendenzielle Unterschiede zu erkennen. Ein 
Anstieg der Sporendichte von $V$. longisporum bei zunehmendem Beatz mit Mikrosklerotien wurde weder in der Wasserkontrolle, noch bei den mit M. ochracea behandelten Rapsstängeln beobachtet (Abb. 10 rechts).

\subsubsection{Interaktion von M. ochracea und V. longisporum im Boden}

Bei diesem Versuchsansatz wurde der Inokulumabbau von V. longisporum durch M. ochracea auf sterilen, mit Mikrosklerotien bewachsenen Rapsstängeln, in sterilen sowie unsterilen Bodensubstraten untersucht. Die Untersuchungen wurden unter kontrollierten Bedingungen in Quarkschalen durchgeführt. Ein Abbau des Inokulums von $V$. longisporum wurde nach 8 Wochen Inkubation über eine Real-time PCR-Untersuchung bestimmt. Eine Besiedlung der Rapsstängel mit M. ochracea wurde mittels PCR untersucht.

Im ersten Versuchsansatz wurden sterile, mit Mikrosklerotien bewachsene Rapsstängel mit M. ochracea bzw. Wasser inokuliert und in sterilem Sand bzw. unsteriler Erde inkubiert. Bei nicht inokulierten und mit $M$. ochracea inokulierten Rapsstängeln wurde ein höherer DNA-Gehalt von V. longisporum nach Inkubation in sterilem Sand als nach Inkubation in unsteriler Erde gemessen.

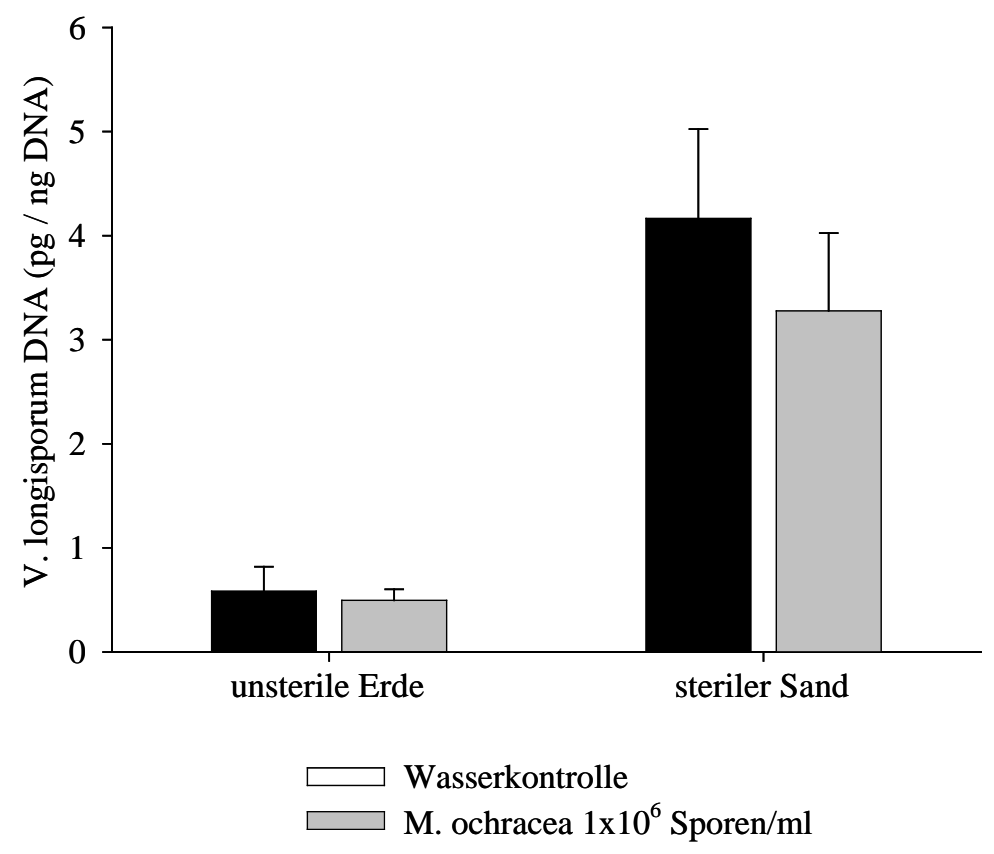

Abb. 11: DNA-Gehalt von $V$. longisporum in Rapsstängeln die steril mit Mikrosklerotien bewachsenen waren und mit M. ochracea inokuliert wurden. Die Rapsstängel wurden mit $M$. ochracea $\left(1 \times 10^{6}\right.$ Sporen $\left./ \mathrm{ml}\right)$ bzw. Wasser inokuliert und für 8 Wochen in unsteriler Erde bzw. sterilem Sand in Quarkschalen bei $20^{\circ} \mathrm{C}$ im Dunkeln inkubiert; $n=4$; Fisher-Test (LSD); $\mathrm{p} \leq 0,05$. 
Nach der Inkubation im Sandsubstrat wurde bei den Rapsstängeln, die mit M. ochracea behandelt wurden ein tendenziell geringerer DNA-Gehalt von V. longisporum im Vergleich zur Wasserkontrolle ermittelt. Eine solche Tendenz war nach Inkubation im unsterilen Erdsubstrat nicht zu erkennen (Abb. 11).

Um die Besiedlung der Rapsstängel mit M. ochracea zu überprüfen, wurde das Rapsstängelgewebe mittels PCR untersucht. Nach der Inkubation mit M. ochracea inokulierter Rapsstängel in unsteriler Erde konnte M. ochracea nur in einer (Probe 3) von vier Wiederholungen mit einem schwachen Signal nachgewiesen werden. In den Wasserkontrollen (Proben 5-8) konnte M. ochracea nicht nachgewiesen werden. Im Gegensatz dazu wurde $M$. ochracea auf allen Rapsstängeln eindeutig nachgewiesen, die mit M ochracea inokuliert und in sterilem Sand inkubiert wurden (Probe 9-12). Auch in der Wasserkontrolle erfolgte ein Nachweis bzw. schwacher Nachweis von M. ochracea in zwei von vier Proben (Probe 13, 14), was vermutlich auf Verunreinigungen während der DNA-Extraktion zurückzuführen ist (Abb. 12 oben). Vollständige Hemmungen der PCR-Reaktionen durch PCR-Inhibitoren konnten durch die Positivkontrollen ausgeschlossen werden (Abb. 12 unten).

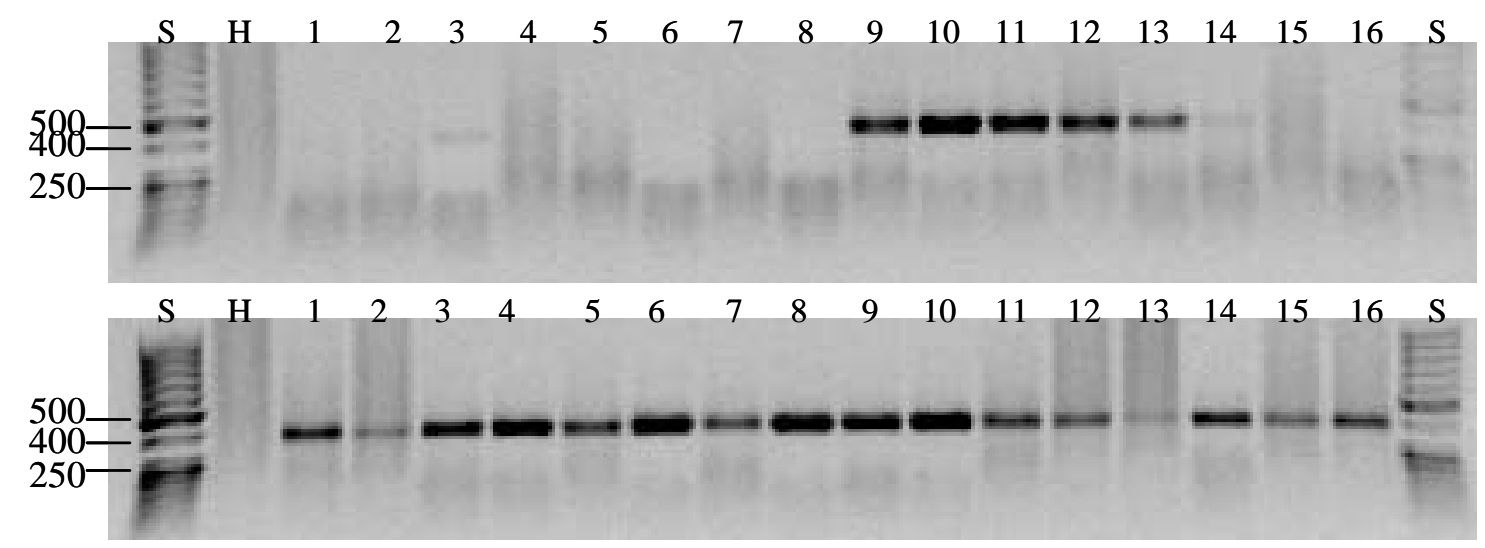

Abb. 12: Nachweis von M. ochracea mittels PCR auf Rapsstängeln die steril mit Mikrosklerotien bewachsenen waren und mit M. ochracea inokuliert wurden. Die Rapsstängel (Rs) wurden mit M. ochracea (M.o) (1x10 Sporen/ml) bzw. Wasser inokuliert und für 8 Wochen in unsteriler Erde bzw. sterilem Sand in Quarkschale bei $20^{\circ} \mathrm{C}$ im Dunkeln inkubiert; oben: S: Größeenstandard 50bp DNA Leiter; H: PCR Wasserkontrolle; 1-4: Rs + M.o unsterile Erde; 5-8: Rs + $\mathrm{H}_{2} \mathrm{O}$ unsterile Erde; 9-12: Rs + M.o steriler Sand; 13-16: $\mathrm{Rs}+\mathrm{H}_{2} \mathrm{O}$ steriler Sand; Unten: positivkontrolle (Proben-DNA + 100pg M.o DNA); 1,2\%iges Agarosegel.

In einem weiteren Versuchsansatz wurde das Wachstum von M. ochracea auf unsterilen, stark mit $V$. longisporum befallenen Rapsstängeln vom Feld untersucht. Die 
Rapsstängel wurden mit M. ochracea inokuliert und in bzw. auf unsteriler/steriler Erde und unsterilem/sterilem Sand in Quarkschalen inkubiert. Eine Besiedlung der Rapsstängel mit M. ochracea wurde mittels PCR untersucht.

Acht Wochen nach Inokulation der Rapsstängel mit M. ochracea und Inkubation in bzw. auf unsteriler und steriler Erde konnte M. ochracea in keiner der Proben nachgewiesen werden (Abb. 13 links oben). Wurden die mit M. ochracea inokulierten Rapsstängel auf unsterilem Sand und in sterilem Sand inkubiert, konnte M. ochracea auf je einer Probe (Proben 24, 34) schwach nachgewiesen werden (Abb. 13 rechts oben).

Hierbei muss berücksichtigt werden, dass es bei den meisten Proben zu einer vollständigen Hemmung der PCR-Reaktionen durch PCR-Inhibitoren kam, was durch die Positivkontrollen überprüft wurde (Abb. 13 unten).

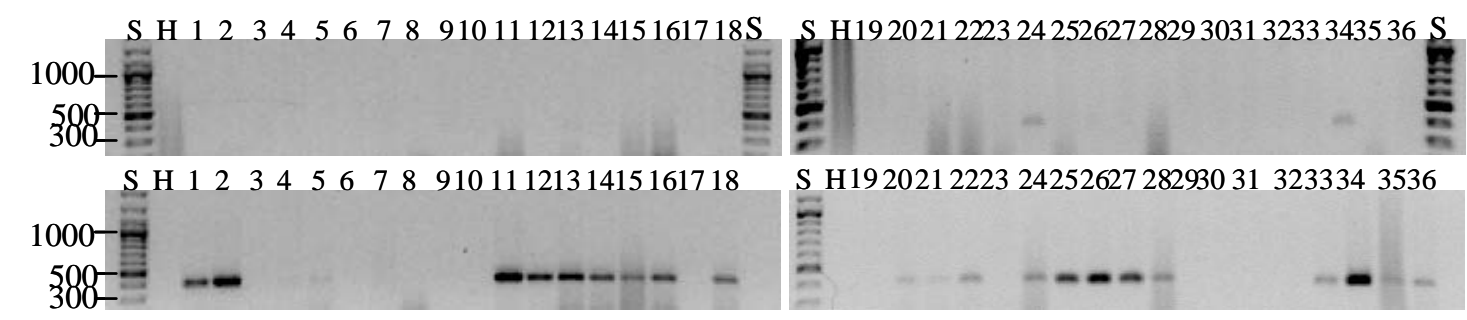

Abb. 13: Nachweis von M. ochracea mittels PCR auf unsterilen stark mit $V$. longisporum befallenen Rapsstängeln (Rs) die mit Sporensuspension von M. ochracea (M.o) (1x10 ${ }^{6}$ Sporen/ml) bzw. $\mathrm{H}_{2} \mathrm{O}$ inokuliert wurden. Die Proben wurden für 8 Wochen auf bzw. in steriler Erde (st. E) und unsteriler Erde (unst. E) und auf bzw. in sterilem Sand (st. S) und unsterilem Sand (unst. S) in Quarkschalen bei $20^{\circ} \mathrm{C}$ im Dunkeln inkubiert; S: Größenstandard 100bp DNA Leiter plus; H: PCR Wasserkontrolle; oben links: 1-2: auf st. E $+\mathrm{H}_{2} \mathrm{O}$; 3-6: auf unst. E + M.o; 7-10: in unst. E + M.o; 11-14: auf st. E + M.o; 15-18: in st. E + M.o; unten links: Positivkontrolle (Proben DNA + 100pg M.o DNA); oben rechts: 19-20: auf st. S. $+\mathrm{H}_{2} \mathrm{O}$; 21-24: auf unst. S + M.o; 25-28: in unst. S + M.o; 29-32: auf st. S + M.o; 33-36: in st. S + M.o; unten rechts: Positivkontrolle (Proben DNA + 100pg M.o DNA) 1,2\%iges Agarosegel.

\subsubsection{Reproduktion von M. ochracea in Abhängigkeit vom Licht}

Bei diesem Versuchsansatz wurde die Pyknidienbildung durch M. ochracea auf Rapsstängeln und die Sporenproduktion von M. ochracea auf OA-Nährmedium in Abhängigkeit der Belichtung untersucht. Hierfür wurden sterile Rapsstängel bzw. OANährmedium mit M. ochracea inokuliert und für 15 Tage bei $20^{\circ} \mathrm{C}$ und $16 \mathrm{~h} \mathrm{Licht} / 8 \mathrm{~h}$ Dunkelheit bzw. 24 h Dunkelheit inkubiert. 
Bei Belichtung der Rapsstängel die mit M. ochracea inokuliert waren, wurden durchschnittlich 140 Pyknidien pro cm Rapsstängel gebildet. Auf den Rapsstängeln die mit M. ochracea inokuliert waren und im Dunkeln inkubiert wurden, wurde ein starkes Myzelwachstum von M. ochracea beobachtet und nur eine geringe Pyknidienbildung von durchschnittlich 3 Pyknidien pro cm Rapsstängel bonitiert. Unter Lichteinfluss wurden auf mit M. ochracea inokulierten Rapsstängeln signifikant mehr Pyknidien gebildet, als auf mit M. ochracea inokulierten Rapsstängeln die im Dunkeln inkubiert wurden (Abb. 14).

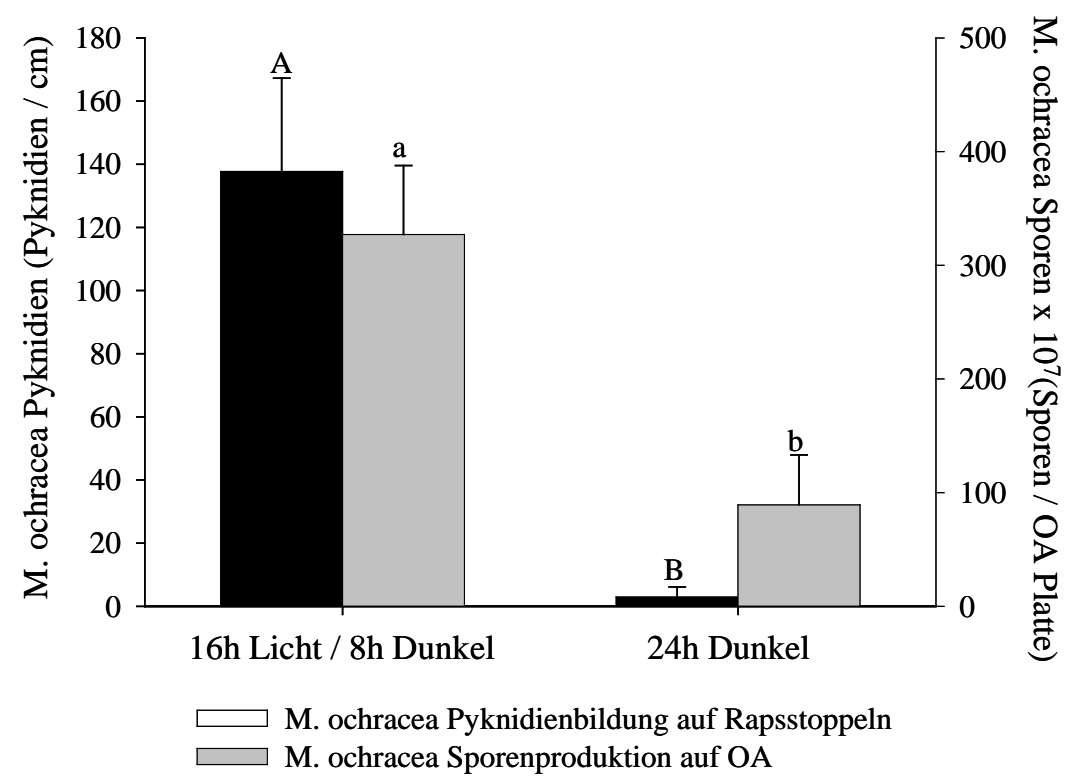

Abb. 14: Pyknidienbildung von M. ochracea auf Rapsstängeln (Pyknidien/cm Rapsstängel) und Sporenproduktion von M. ochracea auf OA-Nährmedium 15 dpi. Die Inokulation erfolgte mit Sporensuspension von $M$. ochracea $\left(1 \times 10^{6}\right.$ Sporen/ml). Die Inkubation erfolgte bei $20^{\circ} \mathrm{C}$ und $16 \mathrm{~h}$ Licht $/ 8 \mathrm{~h}$ Dunkel bzw. 24 h Dunkelheit; $n=4$; Fisher-Test (LSD); $\mathrm{p} \leq 0,05$.

Nach der Inokulation von OA-Nährmedien mit M. ochracea und Inkubation unter Licht wurde nach 15 Tagen eine sehr starke Pyknidienbildung und ein geringes Myzelwachstum beobachtet. Auf den unter Lichtausschluss inkubierten Nährmedien wurde hingegen ein sehr starkes Myzelwachstum beobachtet und es hatte sich nur eine geringe Anzahl von Pyknidien gebildet. Durch die Belichtung wurden auf OA signifikant mehr Sporen von M. ochracea, im Verglich zu unter Lichtausschluss inkubierten Nährmedien, gebildet (Abb. 14). 


\subsubsection{Wirkung der Bodenfungistasis auf die Sporenkeimung von}

\section{M. ochracea}

Bei den durchgeführten Versuchen wurde der Einfluss der Bodenfungistasis auf die Sporenkeimung von M. ochracea auf unterschiedlichen Böden untersucht. Darüber hinaus wurde untersucht, ob die Bodenfungistasis durch Autoklavieren bzw. Zugabe von Glukose überwunden werden kann. Um ausschließlich die Wirkung der Bodenfungistasis auf die Sporenkeimung zu werten, wurde die Sporenkeimung auf den Erdsubstraten mit der Sporenkeimung auf Wasseragar verrechnet und daraus die relative Sporenkeimrate (rSPKR) berechnet.

Nach Inkubation der Sporen von M. ochracea auf frischem Erdsubstrat wurde nur vereinzelt („Felderde“) eine Sporenkeimung beobachtet. Größtenteils kam es weder zu einer Sporenquellung, noch zu einer Sporenkeimung (Abb. 15 A). Nach Inkubation der Sporen von M. ochracea auf autoklavierter Erde konnte nach anfänglicher Sporenquellung (1) mit deutlicher Volumenvergrößerung, eine Sporenkeimung (2) mit Ausbildung eines Keimschlauches (3) beobachtet werden (Abb. 15 B). Zur Bestimmung der relativen Sporenkeimrate (rSPKR in \%) wurden ausschließlich eindeutig gekeimte Sporen erfasst.
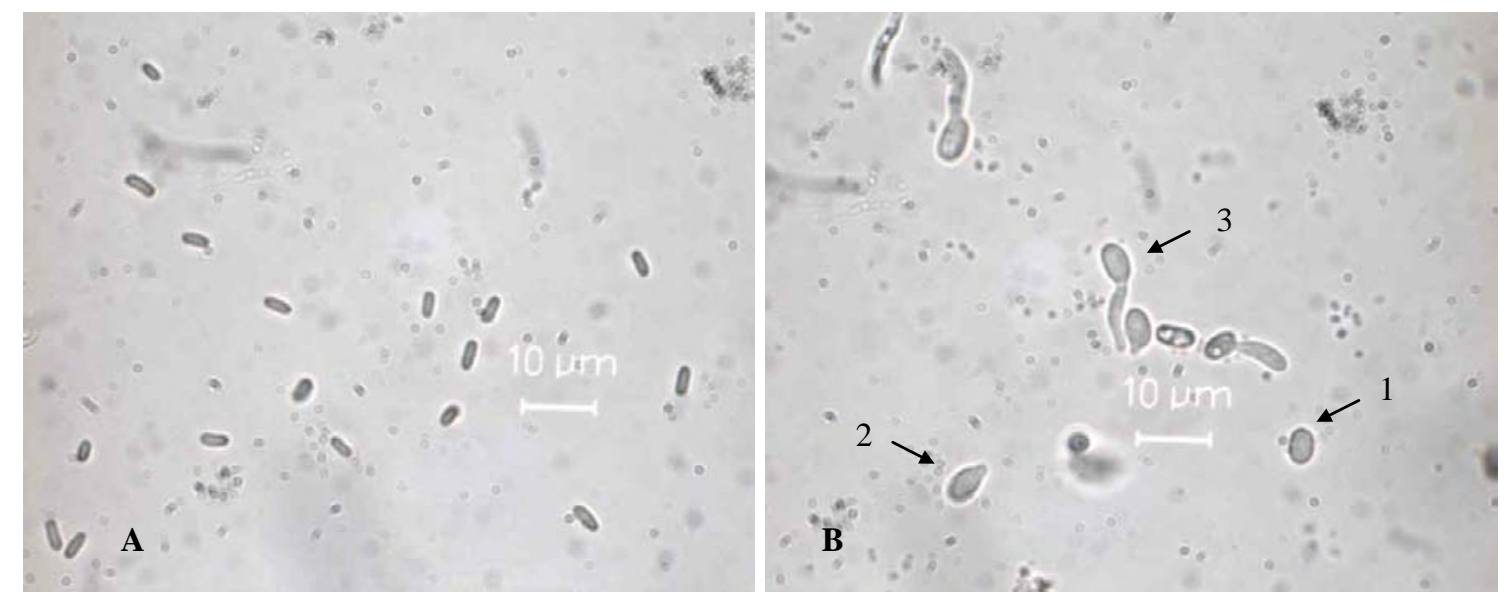

Abb. 15: Sporen von M. ochracea (M.o.) nach 48 h Inkubation auf frischer Erde (A) und autoklavierter Erde (B). 1: gequollene M.o. Spore; 2: keimende M.o. Spore; 3: M.o. Spore mit Keimschlauch; 1000fache Vergrößerung.

Bei der Überprüfung der Sporenkeimung von M. ochracea auf frischen Erdsubstraten wurde ausschließlich bei der „Felderde“ eine geringe Sporenkeimung ermittelt. Diese war mit 5\% rSPKR tendenziell höher, verglichen mit den Testerden „Botanischer Garten“ und „Dauergrünland“, wo keine Sporenkeimung zu erkennen war. Durch das 
Autoklavieren konnte bei allen Erdsubstraten die Bodenfungistasis aufgehoben werden, wodurch signifikant höhere rSPKR im Vergleich zu den frischen Erdsubstraten ermittelt wurden. Nach dem Autoklavieren wurde bei dem Erdsubstrat „Dauergrünland“ eine tendenziell höhere rSPKR als bei „Felderde“, und eine signifikant höhere rSPKR als bei „Botanischen Garten“ ermittelt (Abb. 16).

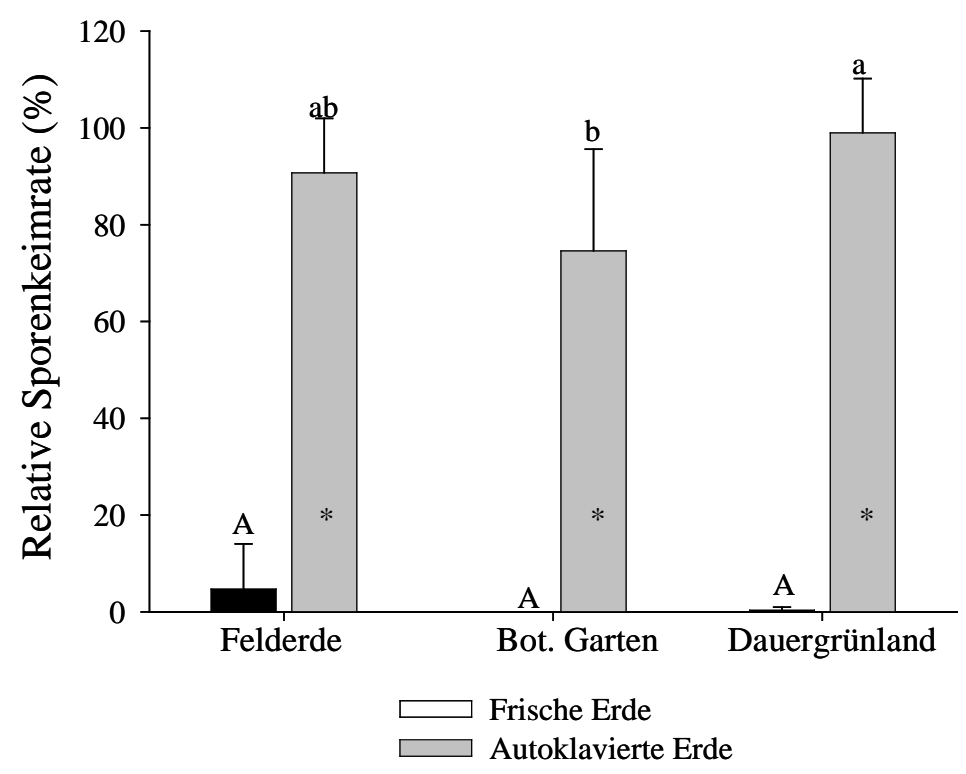

Abb. 16: Relative Sporenkeimrate von $M$. ochracea nach 48 h Inkubation auf frischer und autoklavierter Erde. Dargestellt ist die relative Sporenkeimrate (rSPKR) (Sporenkeimung auf Erdsubstrat : Sporenkeimung auf WA) in \% bei den Erdsubstraten „Felderde“, „botanischer Garten“ und „Dauergrünland“. * signifikanter Unterschied zwischen den Behandlungen (frisch / autoklaviert) eines Erdsubstrates. untersch. Buchstaben bezeichnen signifikante Unterschiede zwischen den Erdsubstraten innerhalb der Behandlung; $n=4$; FisherTest (LSD); $\mathrm{p} \leq 0,05$.

In einem weiteren Versuch wurde untersucht, ob die Bodenfungistasis durch Zugabe von 1\%iger bzw 2\%iger Glukoselösung zu den frischen Erdsubstraten reduziert werden kann. Zur Kontrolle wurde die Sporenkeimung auf frischen und autoklavierten Erdsubstraten getestet. Als Bodensubstrate wurde „Felderde“ vom Feldversuchsstandort „Große Lage“ und das für Gewächshausversuche verwendete Erdsubstrat „Lößlehm“ verwendet.

Bei der frischen „Felderde“ wurde eine rSPKR von 11\% ermittelt. Diese konnte durch Zugabe einer 10\%igen Glukoselösung tendenziell auf 34\% rSPKR gesteigert werden, wohingegen durch Zugabe 2\%iger Glukoselösung keine Steigerung der rSPKR im Vergleich zur frischen Erde erreicht wurde. Die höchste rSPKR wurde bei der 
autoklavierten „Felderde“ beobachtet. Dieser Wert lag signifikant über dem aller anderen Behandlungsvarianten.

Beim Erdsubstrat „Lößlehm“ wurde nach Inkubation der Sporen von M. ochracea auf frischem Erdsubstrat keine Sporenkeimung beobachtet. Nach Zugabe von 2\%iger und 10\%iger Glukoselösung konnte die rSPKR tendenziell um 12\% und 21\% gesteigert werden. Die höchste rSPKR wurde auch bei diesem Erdsubstrat nach dem Autoklavieren ermittelt. Die rSPKR lag signifikant über den Behandlungsvarianten Frisch, Frisch + 2\%ige Glukoselösung und tendenziell über der Versuchsvariante Frisch + 10\%iger Glukoselösung (Tab. 15).

Tab. 15: Relative Sporenkeimrate von $M$. ochracea nach 48 h Inkubation auf frischem Erdsubstrat, autoklaviertem Erdsubstrat und frischem Erdsubstrat $+2 \%$ iger bzw. 10\%iger Glukoselösung. Dargestellt sind Mittelwert und Standardabweichung $(\mathrm{Mw} \pm$ Stabw) der relativen Sporenkeimrate (rSPKR) (Sporenkeimung auf Erdsubstrat: Sporenkeimung auf WA) in \%; $n=4$; Fisher-Test (LSD); $\mathrm{p} \leq 0,05$.

\begin{tabular}{lcc}
\hline & $\begin{array}{c}\text { Felderde } \\
\text { rSPKR (\%) }\end{array}$ & $\begin{array}{c}\text { Lößlehm } \\
\text { rSPKR (\%) }\end{array}$ \\
\hline Wasseragar & 100 & 100 \\
Frisch & $11 \pm 8 \mathrm{~B}$ & $0 \pm 0 \mathrm{~b}$ \\
Autoklaviert & $109 \pm 30 \mathrm{~A}$ & $43 \pm 26 \mathrm{a}$ \\
Frisch + 2\%ige Glukoselösung & $10 \pm 2 \mathrm{~B}$ & $12 \pm 10 \mathrm{~b}$ \\
Frisch + 10\%ige Glukoselösung & $34 \pm 14 \mathrm{~B}$ & $21 \pm 9 \mathrm{ab}$ \\
\hline
\end{tabular}

\subsubsection{Interaktionsversuche mit $F$.graminearum und M. ochracea in vitro}

Bei den durchgeführten Versuchen wurde das mykoparasitische Potential von M. ochracea auf Myzel und Perithezien von F. graminearum (G. zeae) und somit die Askosporenaussschleuderung von $F$. graminearum in vitro untersucht.

15 Tage nach Inokulation von mit Myzel bewachsenen Haferkörnern mit M. ochracea wurde eine tendenziell geringere Askosporenausschleuderung pro WA-Platte bei behandelten Haferkörnern verglichen zur Wasserkontrolle festgestellt. 30 dpi wurde eine signifikant geringere Askosporenausschleuderung von F. graminearum in der mit 
M. ochracea behandelten Variante im Vergleich zur Wasserkontrolle beobachtet (Abb. 17).

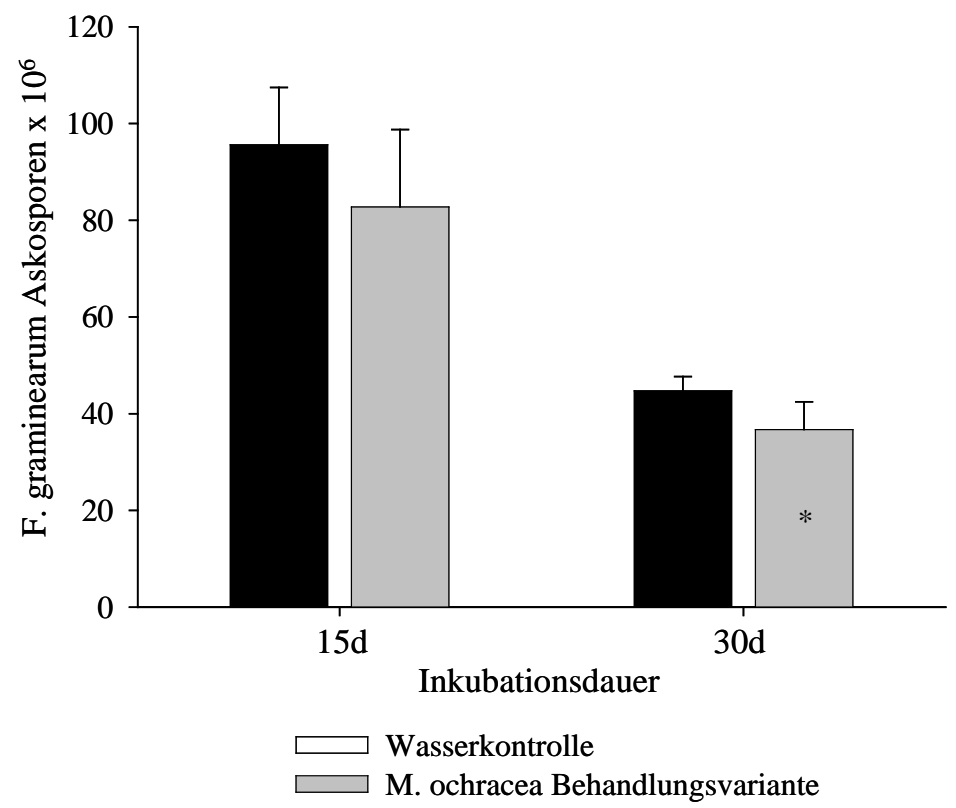

Abb. 17: Askosporenausschleuderung von F.graminearum 15 und 30 Tage nach Inokulation der mit Myzel von F. graminearum bewachsenen Haferkörnern mit Wasser bzw. Sporensuspension von M. ochracea $\left(1 \times 10^{6}\right.$ Sporen $\left./ \mathrm{ml}\right)$. Dargestellt ist die Askosporenausschleuderung von 20 myzelbewachsenen Haferkörnern pro WA-Platte nach Inkubation bei Dauerlicht und $20^{\circ} \mathrm{C}$; * signifikante Unterschiede zwischen der Wasserkontrolle und der Behandlungsvariante; $n=5$; Fisher-Test (LSD); $\mathrm{p} \leq 0,05$.

In einem weiteren Versuchsansatz wurde die Askosporenausschleuderung von perithezienbewachsenen Haferkörneren nach Inokulation mit M. ochracea bzw. M. ochracea WG untersucht. 15 Tage nach Inokulation der Haferkörner mit Sporensuspension von M. ochracea bzw. M. ochracea WG ( $1 \times 10^{8}$ Sporen $\left./ \mathrm{ml}\right)$, wurde eine signifikant geringere Askosporenausschleuderung im Vergleich zur Wasserkontrolle ermittelt. Auch nach Inokulation mit M. ochracea WG und einer Sporendichte von $1 \times 10^{4}$ Sporen/ml wurde eine tendenziell geringere Ausschleuderung von Askosporen im Vergleich zur Wasserkontrolle beobachtet. Nach Behandlung mit M. ochracea (1 x $10^{4}$ Sporen/ml) wurden hingegen inverse Ergebnisse erzielt (Abb. 18). 


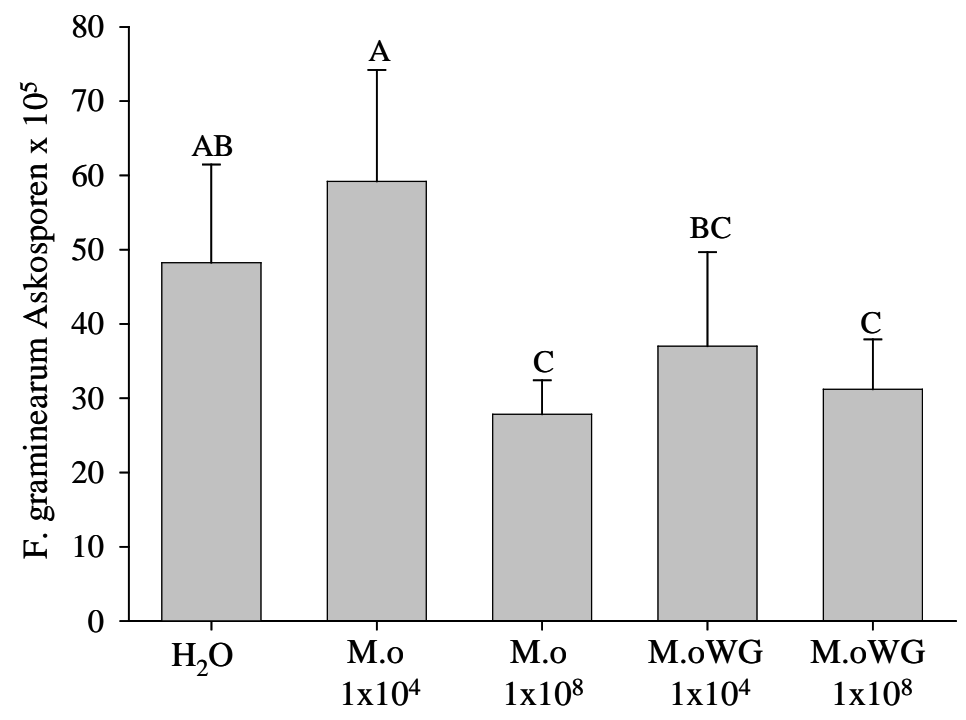

Abb. 18: Askosporenausschleuderung von F. graminearum 15 Tage nach Inokulation von Haferkörnern die mit Perithezien bewachsen waren und mit $\mathrm{H}_{2} \mathrm{O}$ bzw. Sporensuspension von $M$. ochracea behandelt wurden. Dargestellt ist die Askosporenausschleuderung von 20 Haferkörnern pro WA-Platte nach Inokulation mit $\mathrm{H}_{2} \mathrm{O}$ oder Sporensuspension von $M$. ochracea bzw. M. ochracea WG (1x10 ${ }^{4}, 1 \times 10^{8}$ Sporen/ml); Fisher-Test (LSD); $\leq 0,05$. 


\subsection{Nachweis von M. ochracea mittels artspezifischer PCR}

Ziel bei der Entwicklung einer für M. ochracea spezifischen PCR war es, eine Nachweismethode für M. ochracea unter Labor-, Gewächshaus- und Feldbedingungen zu entwickeln. Darüber hinaus sollten Verwechslungen von $M$. ochracea und P. lingam aufgrund ähnlicher Pyknidienformen ausgeschlossen werden.

\subsubsection{Entwicklung spezifischer Primer für M. ochracea}

Nach erfolgreicher Anzucht von M. ochracea und darauf folgender DNA-Extraktion wurden rDNA-Abschnitte, welche die „Internal Transcribed Spacer“ (ITS) Regionen 1 und 2 beinhalten, mittels dem von White et al., (1991) entwickelten Primerpaar ITS 4 und ITS 5 amplifiziert. Nach der Auftrennung der PCR-Produkte auf einem Agarosegel und Extraktion der Amplifikationsprodukte, wurden diese in den Plasmidvektor pGEMTeasy ligiert, welcher wiederum in E. coli transformiert wurde. Nach erfolgter Vermehrung von E. coli wurden die Plasmide extrahiert und das inserierte DNA-Fragment sequenziert (Abb. 1, Anhang).

Basierend auf den sequenzierten ITS-Bereichen wurden Primerpaare für den spezifischen Nachweis von M. ochracea abgeleitet. Durch Abgleich der ITS-Sequenz von M. ochracea mit den ITS-Sequenzen von Alternaria alternata, Aspergillus niger, Botrytis fabae, Coniothyrium minitans, Gaeumannomyces graminis, Gibberella zeae, Leptosphaeria maculans, Penicillium pinophilum, Plasmodiophora brassicae, Pythium ultimum, Rhizoctonia solani, Epicoccum nigrum, Sclerotinia sclerotiorum, Microdochium nivale, Olpidium brassicae und Verticillium longisporum wurden die in Tab. 16 dargestellten Primer abgeleitet. Die Primersynthese wurde von der Firma Invitrogen (Karlsruhe) durchgeführt.

Tab. 16: Nukleotidsequenz und amplifizierte Produktgröße der $M$. ochracea Primer M.o 3.1-F und M. o 4.1.1-R.

\begin{tabular}{|c|c|c|c|}
\hline Bezeichnung & $\begin{array}{c}\text { Nukleotidsequenz } \\
5^{\prime}-3^{\prime}\end{array}$ & $\begin{array}{c}\text { Länge } \\
\text { (bp) }\end{array}$ & $\begin{array}{c}\text { Produktgröße } \\
\text { (bp) }\end{array}$ \\
\cline { 1 - 3 } M.o 3.1-F & CGC CGC TGG AAC CAC ATC & 18 & \multirow{2}{*}{391} \\
\cline { 1 - 3 } M.o 4.1.1-R & CGA GGT CAA AGA CGG TAA GTGG & 23 & \\
\hline
\end{tabular}




\subsubsection{Optimierung der PCR-Reaktion}

\subsubsection{Annealing-Temperatur}

Ein wichtiger Faktor für die Spezifität des Primerpaares ist die Annealing-Temperatur. Diese richtet sich nach der Schmelztemperatur des Primers. Um die optimale Annealing-Temperatur der Primer zu ermitteln, wurde eine Gradienten-PCR mittels einem Gradientencycler durchgeführt. Die Gradienten-PCR wurde bei einer AnnealingTemperatur von $65 \pm 5^{\circ} \mathrm{C}$ und einer $\mathrm{MgCl}_{2}$ Konzentration von 1,5 mM mit dem in Tab. 12 aufgeführten Reaktionsmix und dem in Tab. 13 dargestellten PCR-Programm durchgeführt.

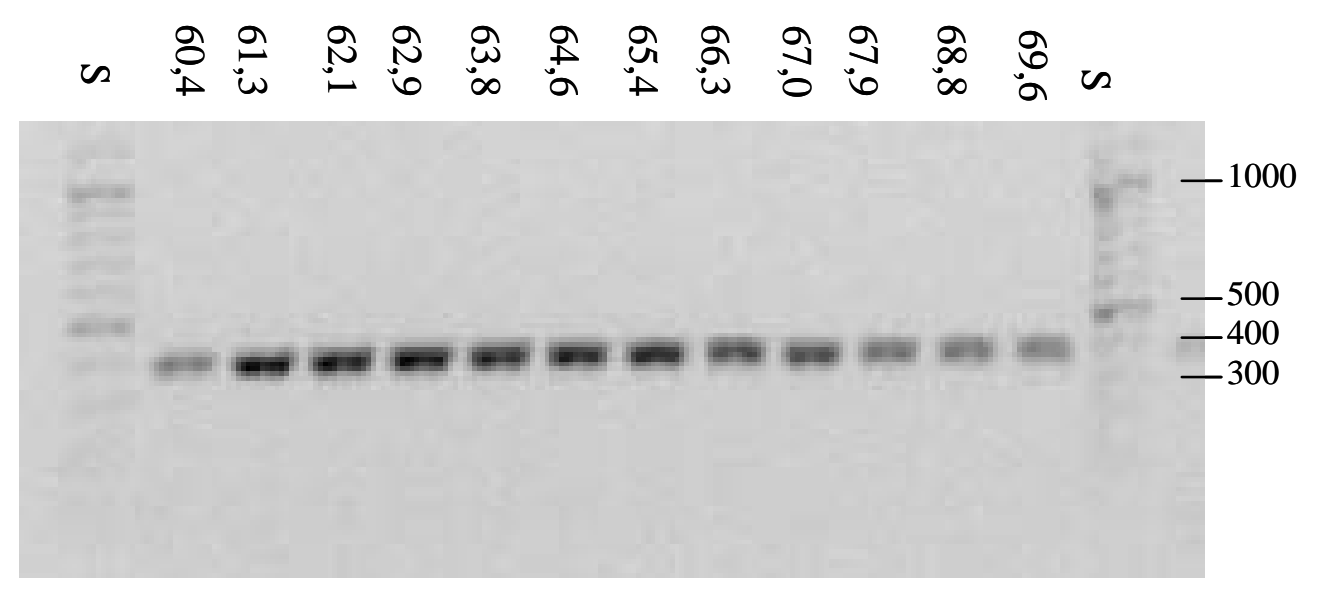

Abb. 19: PCR-Amplifikation von $M$. ochracea spezifischen DNA-Fragmenten mit dem Primerpaar M.o 3.1 / M.o 4.1.1 bei verschiedenen Annealing-Temperaturen $\left(65 \pm 5^{\circ} \mathrm{C}\right)$; S: Größenstandard 100bp Leiter plus; 1,2\%iges Agarosegel.

Bei allen getesteten Temperaturen wurden Amplifikationen von M. ochracea DNAFragmenten der erwarteten Größe nachgewiesen. Hierbei wurden je nach AnnealingTemperatur verschiedene Amplifikatausbeuten erzielt (Abb. 19). Um einen guten Kompromiss zwischen Ausbeute und Amplifikationsspezifität zu erreichen, wurde für die folgenden PCR-Untersuchungen eine Annealing-Temperatur von $65^{\circ} \mathrm{C}$ gewählt.

\subsubsection{Magnesiumkonzentration und Nachweisgrenze für M. ochracea}

Magnesium ist ein Cofaktor der Polymerase und beinflusst einerseits direkt die Aktivität der Polymerase, andererseits können höhere Magnesiumkonzentrationen unspezifische Anlagerungen der Primer bedingen, was wiederum die Produktausbeute beeinflusst. Deshalb muss die Magnesiumkonzentration für jede PCR optimiert werden. In diesem Versuch wurden $\mathrm{MgCl}_{2}$-Konzentrationen von 3 bis 0,5 mM pro Reaktionsansatz in Zusammenhang mit DNA-Konzentrationen von 100, 10 und 1 pg/Reaktion untersucht. 


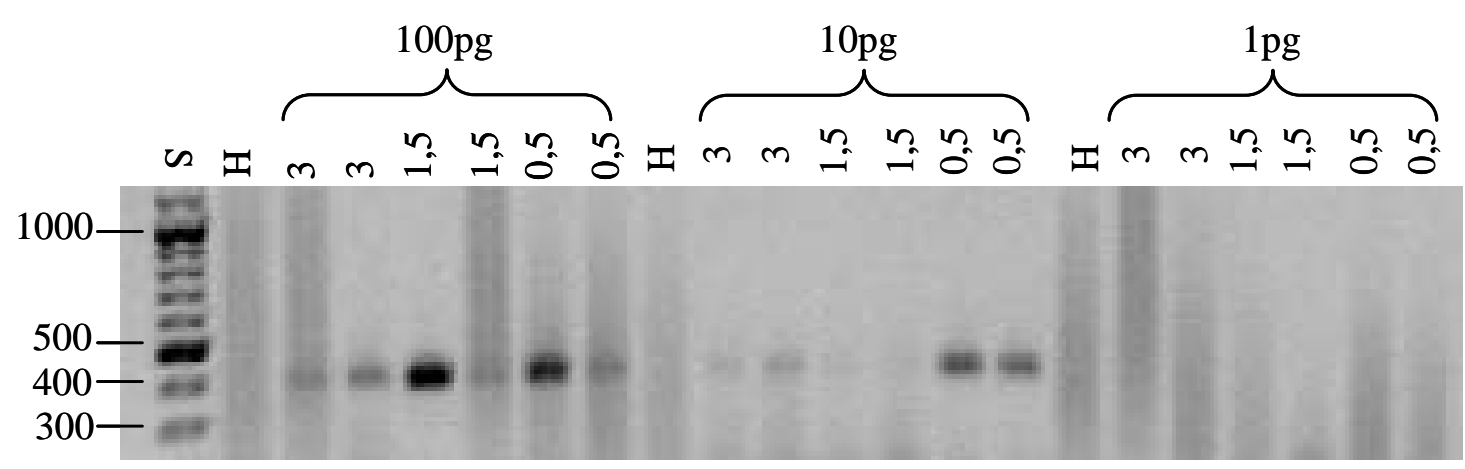

Abb. 20: PCR-Amplifikation M. ochracea spezifischer DNA-Fragmente bei verschiedenen $\mathrm{MgCl}_{2}$-Konzentrationen und $M$. ochracea DNAKonzentrationen. $\mathrm{MgCl}_{2}$-Konzentration (3, 1,5, 0,5 mM); M. ochracea DNAKonzentrationen (100, 10, 1 pg/Reaktion); S: Größenstandard 100 bp Leiter plus; H: PCR Wasserkontrolle; 1,2 \%iges Agarosegel.

Bei einer DNA-Konzentration von 100 pg/Reaktion erfolgte ein Nachweis von M. ochracea bei allen $\mathrm{MgCl}_{2}$-Konzentrationen, wobei die besten Produktausbeuten bei einer $\mathrm{MgCl}_{2}$-Konzentration von 0,5 und 1,5 mM erzielt wurden. Bei einer DNAKonzentration von 10 pg/Reaktion erfolgte ein sicherer Nachweis von M. ochracea bei einer $\mathrm{MgCl}_{2}$-Konzentration von 0,5 mM. M. ochracea konnte bei 1 pg DNA/Reaktion bei keiner der eingesetzten $\mathrm{MgCl}_{2}$-Konzentrationen nachgewiesen werden (Abb. 20).

Aufgrund dieser Ergebnisse wurden für weitere PCR-Untersuchungen $\mathrm{MgCl}_{2}$-Konzentrationen von 0,5 mM im Reaktionsmix verwendet.

\subsubsection{Spezifität der Primer M.o 3.1 und M.o 4.1.1}

Mit Hilfe des Primer Spezifitätstests wurden mögliche Kreuzreaktionen des Primerpaars M.o 3.1 / M.o 4.1.1 mit wichtigen Pathogenen von Raps und Getreide überprüft. Darüber hinaus wurden Kreuzreaktionen mit C. minitans, einem bedeutenden Mykoparasiten, getestet, bei dem mit zuvor getesteten Primern von M. ochracea deutliche Kreuzreaktionen auftraten (vgl. Tab. 7 Anhang; Abb. 2 Anhang). Weitere Spezifitätstests wurden mit DNA aus Pflanzengewebe von Winterweizen, Winterraps und mit DNA aus vier unterschiedlichen Ackerböden durchgeführt.

Bei den Primer-Spezifitätstests wurden keine Kreuzreaktionen der Primer M.o 3.1 und M.o 4.1.1 mit DNA aus Pflanzengewebe, Ackerböden und anderen phytopathogenen Pilzen festgestellt (Abb. 21, Abb. 22). Nach dem Abgleich der Primersequenzen mit den in Datenbanken vorhandenen ITS Sequenzen anderer Pilze, kann von einer hohen Spezifität des Primerpaares für den Nachweis von M. ochracea ausgegangen werden. 


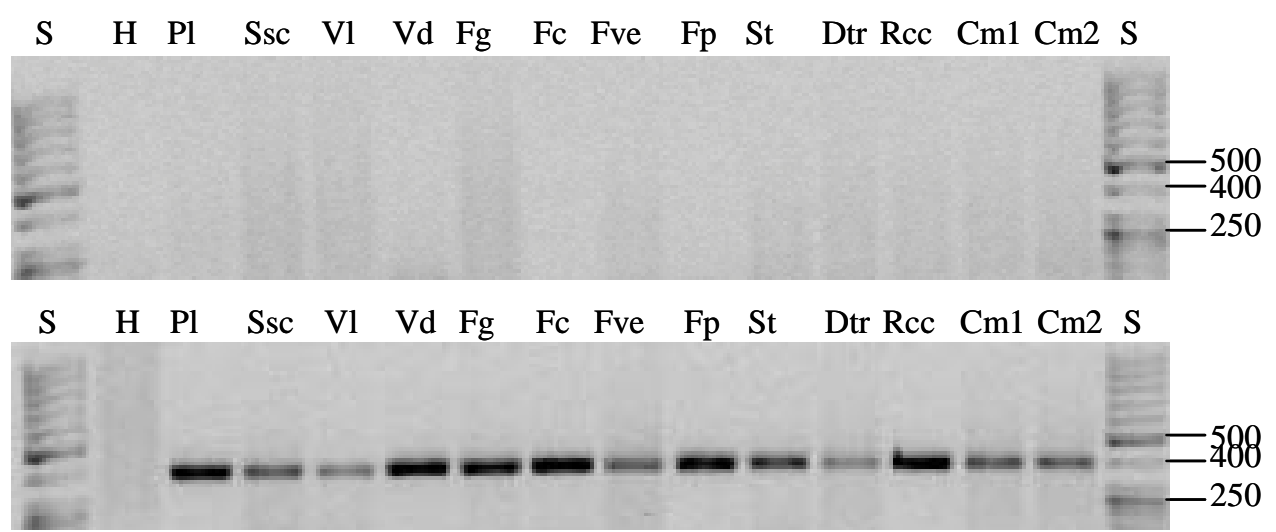

Abb. 21: Spezifitätstest der M. ochracea Primer M.o 3.1 und M.o 4.1.1. Oben: Es wurden mögliche Kreuzreaktionen des Primerpaares mit DNA aus P. lingam ( $\mathrm{Pl}$ ), S. sclerotiorum (Ssc), V. longisporum (Vl), Verticillium dahliae (Vd), F. graminearum (Fg), Fusarium culmorum (Fc), Fusarium verticilloides (Fve), Fusarium proliferatum (Fp), S. tritici (St), D. tritici-repentis (Dtr), Ramularia collo-cygni (Rcc) und C. minitans (Cm) getestet; unten: Positivkontrolle (Proben DNA + 100pg M.o DNA); S: Größenstandard 50bp Leiter; H: PCR Wasserkontrolle; 1,2\%iges Agarosegel.

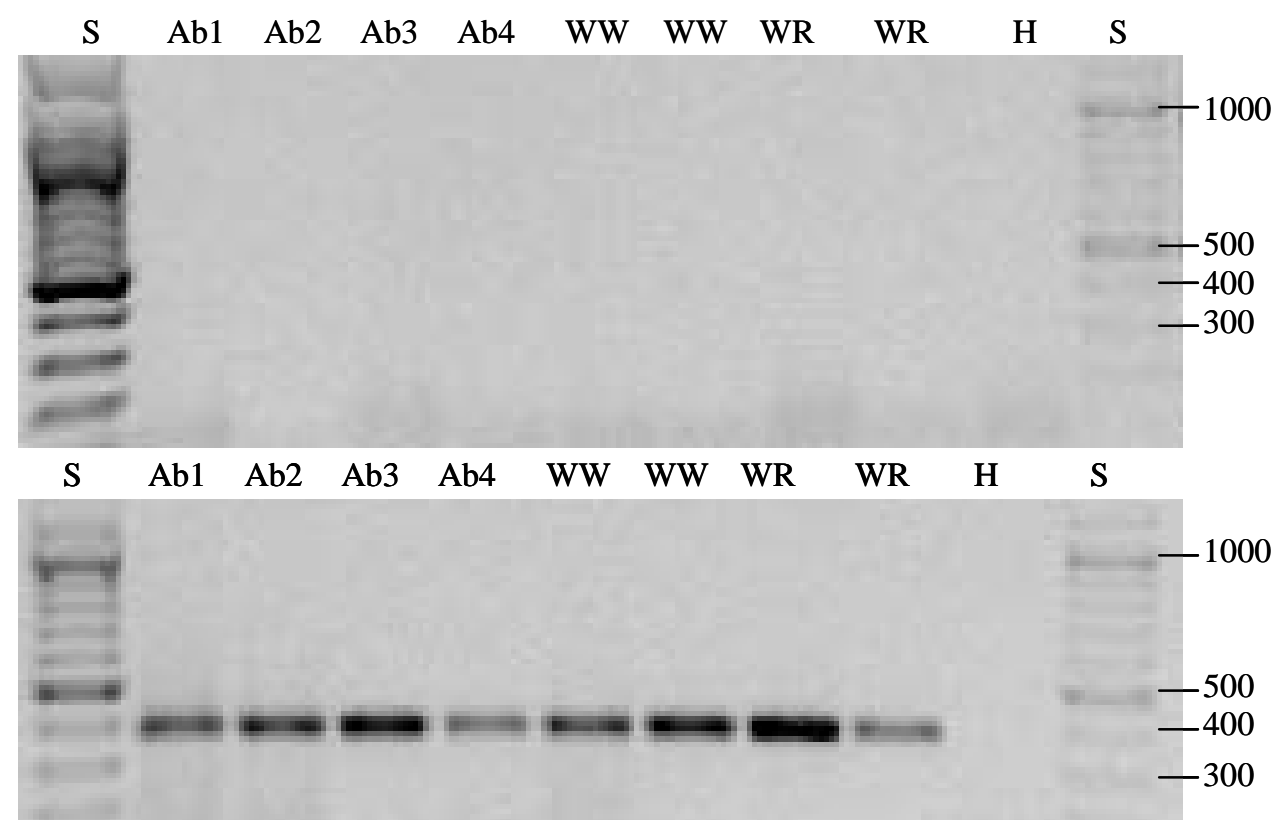

Abb. 22: Spezifitätstest der Primer M.o 3.1 / M.o 4.1.1 von M. ochracea; oben: Es wurden mögliche Kreuzreaktionen des Primerpaares mit DNA aus Ackeböden (Ab), DNA aus Winterweizenstroh (WW) und DNA aus Winterrapsstroh (WR) getestet; unten: Positivkontrolle (Proben DNA + 100pg M.o DNA); S: Größenstandard 100bp Leiter plus; H: PCR Wasserkontrolle; 1,2\%iges Agarosegel. 


\subsection{Gewächshausversuche mit V. longisporum und M. ochracea}

\subsubsection{Inokulationsstufenversuch mit Mikrosklerotien von V. longisporum}

In diesem Versuchsansatz wurde „rapid cycling rapeseed“ (RCR) als Modellpflanze zur Überprüfung der Inokulumdichte von V. longisporum im Boden untersucht. Es wurde zunächst überprüft, wie sich unterschiedliche Mikrosklerotiendichten von V. longisporum (0, 20, 50, 100, $200 \mathrm{mg} / 150 \mathrm{~g}$ Boden) im Boden auf den Befallswert (BW), die Sprosstrockenmasse (STM) und die Pflanzenlänge (PFL) von RCR in unterschiedlichen Entwicklungsstadien auswirken. Danach wurde der Zusammenhang zwischen den aufgeführten Parametern und der Mikrosklerotiendichte von $V$. longisporum im Boden mittels Regressionsanalysen berechnet. Darüber hinaus wurde überprüft, wie weit die Inokulumunterschiede von V. longisporum im Boden mittels RCR als Fangpflanze statistisch abgesichert werden können. Diese Daten dienten als Grundlage für Interaktionsstudien zwischen M. ochracea und Mikrosklerotien von V. longisporum in Gewächshausversuchen und dem Nachweis (Biotest) eines möglichen Inokulumabbaus von $V$. longisporum durch $M$. ochracea in den Litterbagversuchen.

In BBCH 65, 72 und 75 wurde der Befallswert (BW 1-8) von V. longisporum und die Pflanzenlänge (PFL in cm) bestimmt. Eine weitere Messung der Pflanzenlänge wurde in BBCH 79 durchgeführt, bevor die Pflanzen zur Bestimmung der Sprosstrockenmasse (STM in g) geerntet wurden. Bei der linearen Regressionsanalyse wurden nur die Inokulationsstufen 0-100 mg verrechnet, da bei der Innokulationsstufe von 200 mg pro 150 g Boden zwar noch eine Zunahme der Befallssymptome mit $V$. longisporum, aber keine weiter reduzierte Pflanzenlänge und Sprosstrockenmasse im Vergleich zur Inokulationsstufe von 100 mg pro 150 g Boden gemessen wurde.

Die durch visuelle Bonitur erfassten Befallswerte von $V$. longisporum stiegen zu allen Boniturterminen mit zunehmender Mikrosklerotiendichte im Boden an. Trotz der geringen Befallssymptome in BBCH 65 mit Befallswerten von maximal 1,7 war ein enger Zusammenhang $\left(\mathrm{R}^{2}=0,67\right)$ zwischen Befallssymptomen und der Mikrosklerotiendichte im Boden zu erkennen. Mit zunehmendem Pflanzenalter fiel dieser Zusammenhang geringer aus (Tab. 17 oben). 
Tab. 17: Befall von RCR mit $V$. longisporum in Abhängigkeit von der Mikrosklerotiendichte (0, 20, 50, 100, 200 mg/150g Boden) im Boden und dem Entwicklungsstadium; dargestellt sind der Mittelwert und die Standardabweichung ( $\mathrm{Mw} \pm$ Stabw) oben: Befallswert (BW 1-8), Sprosstrockenmasse (STM in g) unten: Pflanzenlänge (PFL in $\mathrm{cm}$ ); Lineare Regressionsanalye mit Regressionsgleichung und Bestimmtheitsmaß $\left(\mathrm{R}^{2}\right)$ für die Inokulationsstufen 0-100mg; unterschiedliche Buchstaben: signifikante Unterschiede zwischen den Inokulationsstufen zum jeweiligen Boniturtermin; $n=5$ (bei 17 technischen WDH), Fisher-Test (LSD) $\mathrm{p} \leq 0,05$.

\begin{tabular}{lcccc}
\hline BW/ & BBCH 65 & BBCH 72 & BBCH 75 & $\begin{array}{c}\text { STM } \\
\text { STM }\end{array}$ \\
\hline 0 & BW 1-8 & BW 1-8 & BW 1-8 & in g \\
\hline 20 mg & $1,2 \pm 0,1 \mathrm{~A}$ & $1,0 \pm 0,1 \mathrm{a}$ & $1,5 \pm 0,2 \mathrm{~A}$ & $2 \pm 0,1 \mathrm{~A}$ \\
$50 \mathrm{mg}$ & $1,5 \pm 0,1 \mathrm{~B}$ & $2,7 \pm 0,7 \mathrm{bc}$ & $3,1 \pm 0,8 \mathrm{BC}$ & $1,7 \pm 0,2 \mathrm{~B}$ \\
$100 \mathrm{mg}$ & $1,5 \pm 0,1 \mathrm{~B}$ & $3,2 \pm 0,5 \mathrm{~cd}$ & $3,6 \pm 0,6 \mathrm{BC}$ & $1,3 \pm 0,1 \mathrm{C}$ \\
$200 \mathrm{mg}$ & $1,7 \pm 0,1 \mathrm{C}$ & $3,6 \pm 0,5 \mathrm{~d}$ & $3,8 \pm 0,6 \mathrm{C}$ & $1,3 \pm 0,2 \mathrm{C}$ \\
\hline Regression & $\mathrm{y}=0,004 \mathrm{x}+1,2$ & $\mathrm{y}=0,02 \mathrm{x}+1,47$ & $\mathrm{y}=0,02 \mathrm{x}+1,96$ & $\mathrm{y}=-0,38 \mathrm{x}+54,4$ \\
$\mathbf{0 - 1 0 0 m g}$ & $\mathrm{R}^{2}=0,67$ & $\mathrm{R}^{2}=0,60$ & $\mathrm{R}^{2}=0,50$ & $\mathrm{R}^{2}=0,57$ \\
\hline
\end{tabular}

\begin{tabular}{lcccc}
\hline PFL & $\begin{array}{c}\text { BBCH 65 } \\
\text { in cm }\end{array}$ & $\begin{array}{c}\text { BBCH 72 } \\
\text { in cm }\end{array}$ & $\begin{array}{c}\text { BBCH 75 } \\
\text { in cm }\end{array}$ & $\begin{array}{c}\text { BBCH 79 } \\
\text { in cm }\end{array}$ \\
\hline 0 & $70 \pm 3 \mathrm{~A}$ & $90 \pm 1 \mathrm{a}$ & $99 \pm 3 \mathrm{~A}$ & $102 \pm 4 \mathrm{a}$ \\
$20 \mathrm{mg}$ & $67 \pm 5 \mathrm{AB}$ & $83 \pm 2 \mathrm{~b}$ & $87 \pm 5 \mathrm{~B}$ & $88 \pm 6 \mathrm{~b}$ \\
$50 \mathrm{mg}$ & $66 \pm 1 \mathrm{AB}$ & $81 \pm 2 \mathrm{~b}$ & $84 \pm 3 \mathrm{~B}$ & $86 \pm 4 \mathrm{~b}$ \\
$100 \mathrm{mg}$ & $63 \pm 2 \mathrm{~B}$ & $75 \pm 2 \mathrm{c}$ & $77 \pm 3 \mathrm{C}$ & $77 \pm 3 \mathrm{c}$ \\
$200 \mathrm{mg}$ & $62 \pm 6 \mathrm{~B}$ & $73 \pm 7 \mathrm{c}$ & $75 \pm 8 \mathrm{C}$ & $76 \pm 7 \mathrm{c}$ \\
\hline Regression & $\mathrm{y}=0,06 \mathrm{x}+69,0$ & $\mathrm{y}=-0,13 \mathrm{x}+87,9$ & $\mathrm{y}=-0,20 \mathrm{x}+95,3$ & $\mathrm{y}=-0,23 \mathrm{x}+98,1$ \\
$\mathbf{0 - 1 0 0 m g}$ & $\mathrm{R}^{2}=0,38$ & $\mathrm{R}^{2}=0,82$ & $\mathrm{R}^{2}=0,76$ & $\mathrm{R}^{2}=0,72$ \\
\hline
\end{tabular}

Mit ansteigender Mikrosklerotiendichte im Boden wurde eine Stauchung der Rapspflanzen beobachtet. Diese trat mit zunehmendem Pflanzenalter verstärkt auf. In BBCH 72, 75 und 79 wurde bei hohen Inokulationsstufen (200, 100 mg pro 150 g Boden) eine signifikant geringere Pflanzenlänge (PFL) im Vergleich zu den niedrigen Inokulationsstufen (50, 20 mg pro 150 g Boden) und der Kontrolle gemessen. Signifikante Längenunterschiede wurden in $\mathrm{BBCH}$ 72, 75 und 79 auch zwischen den niedrigen 
Inokulationsstufen (50, 20 mg pro 150 g Boden) und der Kontrolle ermittelt. In BBCH 72 zeigte sich in der Regressionsanalyse ein stark negativer Zusammenhang $\left(R^{2}=0,82\right)$ zwischen der Pflanzenlänge und der Mikrosklerotiendichte im Boden. Mit zunehmendem Pflanzenalter nahm dieser Zusammenhang leicht ab (Tab. 17 unten).

Ein weiterer wichtiger Parameter zur Quantifizierung des Befalls der Rapspflanzen mit $V$. longisporum und somit der Mikrosklerotiendichte im Boden war die Sprosstrockenmasse (STM in g). In BBCH 79 wurde bei hohen Inokulationsstufen (200 und $100 \mathrm{mg}$ pro 150 g Boden) eine signifikant geringere Sprosstrockenmasse im Vergleich zu niedrigen Inokulationsstufen (50, 20 mg pro 150 g Boden) und der Kontrolle ermittelt. Ein signifikanter Unterschied wurde auch zwischen der $50 \mathrm{mg}$ Inokulumstufe und der Kontrolle gemessen. Somit ergab sich in BBCH 79 ein deutlich negativer Zusammenhang $\left(\mathrm{R}^{2}=0,57\right)$ zwischen Mikrosklerotiendichte im Boden und der Sprosstrockenmasse (Tab. 17 oben).

Aufgrund dieser Ergebnisse wurde RCR bei einem ausreichend großen Stichprobenumfang als geeignete Modellpflanze zur Erfassung eines möglichen Mikrosklerotienabbaus durch M. ochracea für Gewächshausuntersuchungen eingestuft. Zur Untersuchung des mykoparasitischen Potenials von M. ochracea auf Mikrosklerotien von $V$. longisporum in unsterilem Boden wurde eine Mikrosklerotiendichte von maximal 100 mg pro 150 g Boden gewählt. Grund dafür waren die geringen Unterschiede bei den Parametern Pflanzenlänge und Sprosstrockenmasse zwischen den Inokulationsstufen 100 und $200 \mathrm{mg}$. In den folgenden Gewächshausversuchen erfolgte die visuelle Verticillium-Befallsbonitur in $\mathrm{BBCH}$ 65, die Erfassung der Pflanzenlänge in BBCH 72/75 und die Bestimmung der Sprosstrockenmasse in BBCH 79/80, da bei diesen Entwicklungsstadien die stärksten Zusammenhänge zwischen Mikrosklerotiendichte im Boden und den aufgeführten Parametern gefunden wurden.

\subsubsection{Bodeninokulation mit M. ochracea WG als Granulat}

In diesem Versuch wurde das mykoparasitische Potential von M. ochracea auf Mikrosklerotien von $V$. longisporum mit hohen Inokulationsstufen von M. ochracea WG im Boden überprüft.

Eine Woche nach der Aussaat von RCR wurde bei allen mit M. ochracea WG inokulierten Varianten ein starkes Myzelwachstum auf der Bodenoberfläche beobachtet. 
Das Myzel wurde auf OA-Medium überführt und nach visueller Beurteilung als Myzel von M. ochracea identifiziert (nicht dargestellt).

Eine Woche nach der Aussaat wurde bei den Versuchsvarianten, die mit Mikrosklerotien + 1g M. ochracea WG, Mikrosklerotien + 5 g M. ochracea WG und 1g bzw $5 g$ M. ochracea WG inokuliert waren, eine langsamere Entwicklung und Stauchung der Rapspflanzen im Vergleich zu den Positivkontrollen (Mikrosklerotieninokulation) beobachtet (Abb. 23). Dieser Unterschied hob sich zum größten Teil mit fortschreitender Entwicklung auf, konnte aber auch noch in späteren Entwicklungsstadien beobachtet werden.

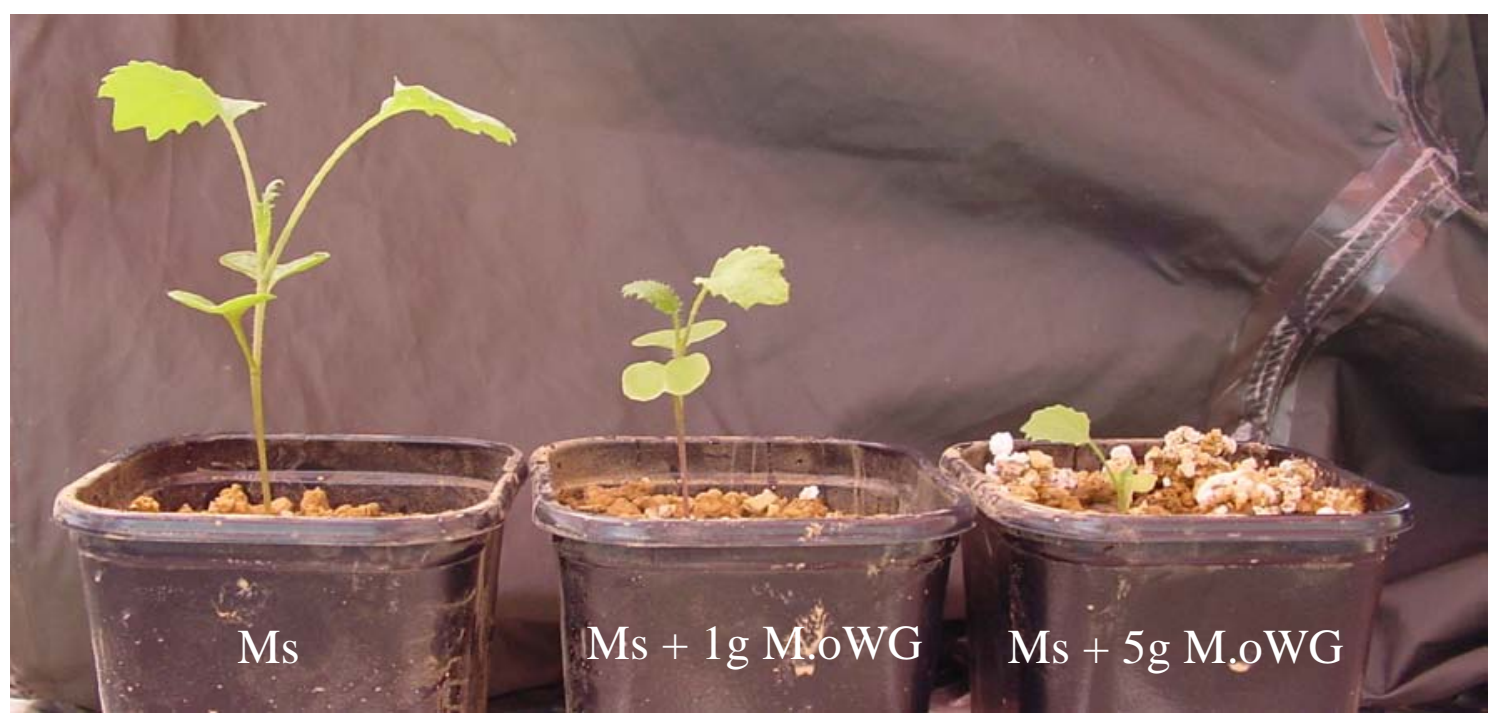

Abb. 23: Pflanzenlängen und Entwicklungsunterschied eine Woche nach der Aussaat von RCR in den Behandlungsvarianten Mikrosklerotien (Ms), Mikrosklerotien $+1 \mathrm{~g}$ M. ochracea WG (Ms + $1 \mathrm{~g}$ M.oWG) und Mikrosklerotien + $5 \mathrm{~g}$ M. ochracea WG (Ms + 5g M.oWG).

Bei der visuellen Bonitur in BBCH 65 wurde der höchste Befall der Modellpflanzen mit V. longisporum, mit einem Befallswert von 2,2 in der Positivkontrolle (Mikrosklerotieninokulation), festgestellt. Dieser lag signifikant über den Befallswerten der Kontrollvarianten mit $1 \mathrm{~g}$ und $5 \mathrm{~g}$ M. ochracea WG. Es traten aber auch in der Kontrollvariante mit $5 \mathrm{~g}$ M. ochracea WG Blattvergilbungen auf, die als Befall mit V. longisporum gewertet wurden. Durch Behandlung des mit Mikrosklerotien beimpften Bodens mit $1 \mathrm{~g}$ bzw. $5 \mathrm{~g}$ M. ochracea WG wurde der visuell erfasste Befall mit V. longisporum signifikant im Vergleich zur Positivkontrolle (Mikrosklerotieninokulation) gesenkt. Dabei wurde bei der hohen Inokulationsstufe (5 g) ein signifikant geringerer Befall der Rapspflanzen mit V. longisporum als in der mit $1 \mathrm{~g}$ M. ochracea WG behandelten Variante beobachtet. Es traten keine Befalls- 
unterschiede zwischen den Kontrollvarianten und der Behandlungsvariante Mikrosklerotien + 5 g M. ochracea WG auf.

Ähnliche Ergebnisse wurden bei der Bestimmung des DNA-Gehaltes von V. longisporum mittels Real-time PCR Untersuchung erzielt. Durch Behandlung des mit Mikrosklerotien beimpften Bodens mit $1 \mathrm{~g}$ bzw. $5 \mathrm{~g}$ M.ochracea WG wurde im Pflanzengewebe von RCR ein signifikant geringerer DNA-Gehalt von V. longisporum im Vergleich zur Positivkontrolle gemessen. Darüber hinaus wurde in der Variante die mit Mikrosklerotien +5 g M. ochracea WG behandelt wurde ein signifikant geringerer DNA-Gehalt von $V$. longisporum als in der mit Mikrosklerotien + 1g M. ochracea WG behandelten Variante gemessen. Es wurden wiederum keine statistisch absicherbaren Unterschiede zwischen den Kontrollvarianten (5 g und 1g M. ochracea WG) und der Variante, die mit Mikrosklerotien + $5 \mathrm{~g}$ M. ochracea WG behandelt wurde gemessen (Abb. 24 links).

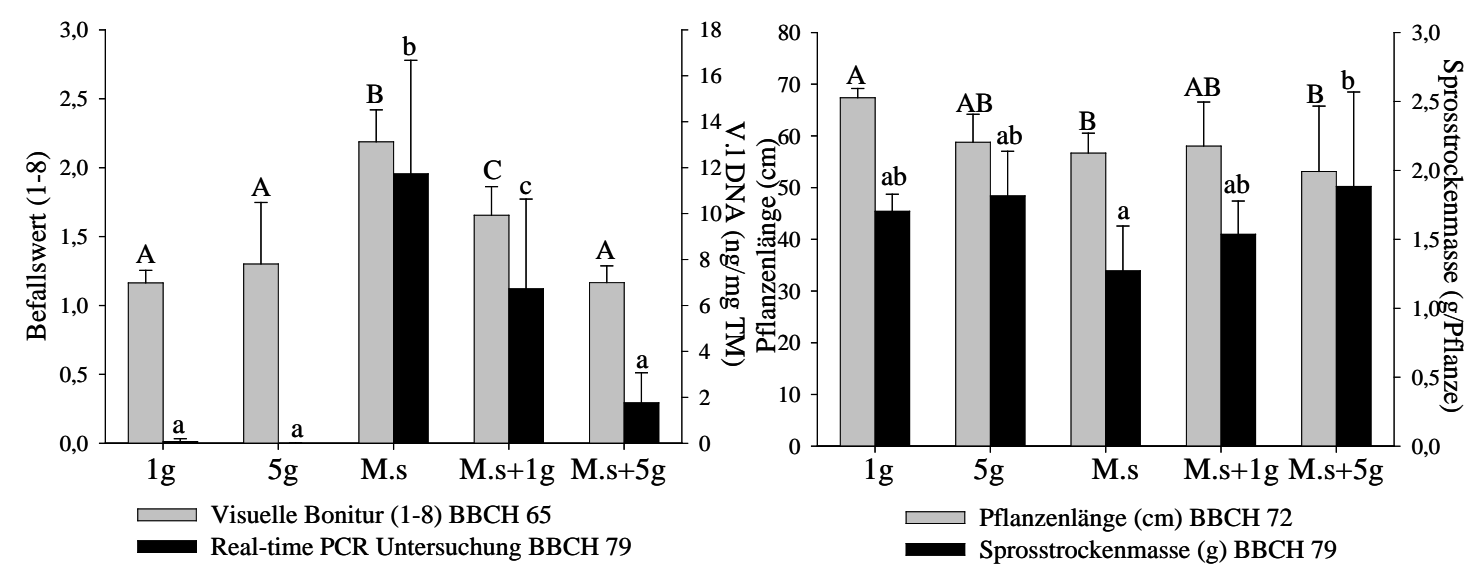

Abb. 24: Befall der Modellrapspflanzen (RCR) mit V. longisporum nach Inokulation von mikrosklerotienbeimpftem Boden mit M. ochracea WG. links: $V$ longisporum Befallswert (1-8) in BBCH 65 und V. longisporum DNA-Gehalt im Pflanzengewebe (ng/mg TM) in $\mathrm{BBCH} 79$; rechts: Pflanzenlänge (cm) in BBCH 72 und Sprosstrockenmasse (g) in BBCH 79; mikrosklerotienfreie Kontrolle mit $1 \mathrm{~g}$ und $5 \mathrm{~g}$ M. ochracea WG (1g, 5g); mit mikrosklerotien beimpfter Boden (Ms); mit mikrosklerotienbeimpfter Boden mit 1g, $5 \mathrm{~g}$ M. ochracea WG (Ms+1g / Ms+5g); n = 5 (bei 10 technischen Wdh.); FisherTest (LSD), $\mathrm{p} \leq 0,05$.

In der Negativkontrolle mit $1 \mathrm{~g}$ M. ochracea WG wurden in BBCH 72 die längsten Pflanzen gemessen. Die kürzesten Pflanzen wurden in der Positivkontrolle (Mikrosklerotieninokulation) und der Behandlungsvariante Mikrosklerotien $+5 \mathrm{~g}$ M. ochracea WG gemessen. Dabei wurde kein statistisch absicherbarer Längen- 
unterschied im Vergleich zur Kontrollvariante mit $5 \mathrm{~g}$ M. ochracea WG ermittelt. Längenunterschiede der Pflanzen werden deshalb in diesem Versuch mit der in Abb. 23 dargestellten entwicklungsverzögernden und planzenlängenbeeinflussenden Wirkung des Produktes M. ochracea WG begründet.

In BBCH 79 wurde die Sprosstrockenmasse bestimmt. Die höchsten Sprosstrockenmassen wurden in den Kontrollvarianten (1 g, 5 g M. ochracea WG) und der Behandlungsvariante Mikrosklerotien + 5 g M. ochracea WG gemessen. Die geringste Sprosstrockenmasse wurde in der Positivkontrolle (Mikrosklerotieninokulation) ermittelt. Durch Behandlungen von mit Mikrosklerotien beimpften Boden mit M. ochracea WG konnte der Sprosstrockenmasseertrag der Modellpflanzen tendenziell (1 g M. ochracea WG) und signifikant (5 g M. ochracea WG) gesteigert werden (Abb. 24 rechts).

Die Ergebnisse dieses Versuches zeigen, daß durch Behandlungen von mit Mikrosklerotien beimpften Boden mit hohen Konzentrationen von M. ochracea WG der Befall der Modellpflanzen mit V. longisporum reduziert werden kann. Dies ist auf eine Reduktion des infektiösen Inokulums von V. longisporum im Boden zurückzuführen.

\subsubsection{Gießapplikation von M. ochracea}

Ziel dieses Versuches war es, die Wirkung von M. ochracea auf Mikrosklerotien von V. longisporum im Boden mit Aufwandmengen (Sporendichten) unter Gewächshausbedingungen zu testen, die auch in der landwirtschaftlichen Praxis bei Feldapplikationen angewendet werden können.

Aus Abb. 25 links ist zu erkennen, dass es in allen Behandlungsvarianten zu einer starken Infektion der Modellrapspflanzen (RCR) mit V. longisporum im Vergleich zur Wasserkontrolle kam. Aufgrund fehlender pflanzenmorphologischer Einflüsse von M. ochracea und M. ochracea WG in diesem Versuchsansatz, wurde auf die Darstellung dieser Daten verzichtet. Es wurde weder bei der visuellen Bonitur, noch bei der Realtime PCR Untersuchung eine Reduktion des V. longisporum-Befalls durch Behandlungen des mit Mikrosklerotien beimpften Bodens mit M. ochracea bzw. M. ochracea WG im Vergleich zur Positivkontrolle (Mikrosklerotieninokulation) gemessen. Bei der Realtime PCR Untersuchung wurde sogar ein erhöhter DNA-Gehalt von V. longisporum im Pflanzengewebe der mit M. ochracea behandelten Varianten im Vergleich zur Positivkontrolle ermittelt. 


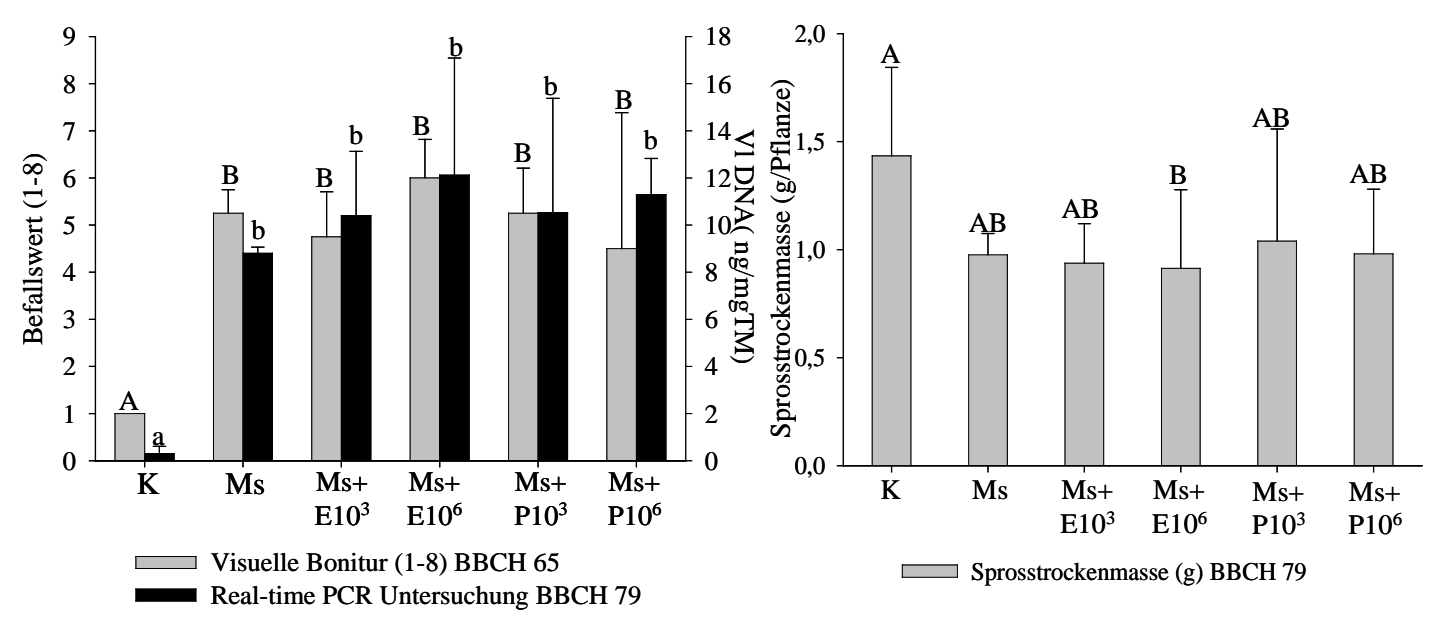

Abb. 25: V. longisporum-Befall (V.l) der Modellrapspflanzen (RCR) nach Inokulation von mit Mikrosklerotien beimpftem Boden mit M. ochracea bzw. M. ochracea WG. links: V. longisporum Befallswert (1-8) in BBCH 65 und V. longisporum DNA-Gehalt im Pflanzengewebe (ng/mg TM) in BBCH 79; rechts: Sprosstrockenmasse (g) in BBCH 79; mikrosklerotienfreie Wasserkontrolle (K); mit Mikrosklerotien beimpfter Boden (Ms); mit Mikrosklerotien beimpfter Boden behandelt mit M. ochracea Sporensuspension $1 \times 10^{3}$ und $1 \times 10^{6}$ Sporen/ml (Ms + E10 ${ }^{3} ;$ Ms $\left.+E 10^{6}\right)$; mit Mikrosklerotien beimpfter Boden behandelt mit M. ochracea WG Sporensuspension $1 \times 10^{3}$ und $1 \times 10^{6}$ Sporen/ml $\left(\mathrm{Ms}+\mathrm{P} 10^{3} ; \mathrm{Ms}+\mathrm{P} 10^{6}\right) ; \mathrm{n}=5$ (bei 10 technischen Wdh.); FisherTest, $\mathrm{p} \leq 0,05$.

Ähnliche Ergebnisse zeigte die Erfassung des Ertrages der Sprosstrockenmasse. In allen mit Mikrosklerotien versetzten Varianten wurde ein geringerer Ertrag der Sprosstrockenmasse im Vergleich zur Wasserkontrolle gemessen. Eine Steigerung der Sprosstrockenmasse durch Behandlung von mikrosklerotienbeimpftem Boden mit M. ochracea bzw. M. ochracea WG konnte nicht nachgewiesen werden (Abb. 25 rechts).

Auf eine Darstellung der Pflanzenlängen wurde aufgrund von widersprüchlichen Ergebnissen zu den hier aufgeführten Parametern verzichtet.

Nach den hier dargestellten Ergebnissen kann durch Behandlung von mit Mikrosklerotien beimpftem Boden mit praxisorientierten Aufwandmengen von M. ochracea bzw. M. ochracea WG das infektiöse Inokulum von V. longisporum im Boden nicht reduziert werden. 


\subsection{Litterbagversuche}

\subsubsection{Abbau von V. longisporum durch M. ochracea im Boden}

Um den Abbau des Inokulums von V. longisporum (Mikrosklerotien) auf befallenen Rapsstängeln im Boden zu untersuchen, wurden in den Jahren 2007/2008 und 2008/2009 Litterbagversuche angelegt (vgl. 2.12.1). Ein möglicher Abbau des Inokulums wurde in anschließenden Biotests im Gewächshaus überprüft.

Im Versuchsjahr 2007/2008 wurde für den Standort „Miniplotanlage“ im anschließenden Biotest bei allen Versuchsvarianten ein Befall der Modellrapspflanzen (RCR) mit $V$. longisporum im Vergleich zur Wasserkontrolle ermittelt. Dieser wurde durch einen höheren V. longisporum-Befallswert (BW), einer reduzierten relativen Pflanzenlänge (rPFL) und einer reduzierten relativen Sprosstrockenmasse (rSTM) in den Behandlungsvarianten im Vergleich zur Kontrolle nachgewiesen. Es konnten weder bei den Proben aus $10 \mathrm{~cm}$ noch aus $20 \mathrm{~cm}$ Bodentiefe ein Inokulumabbau durch M. ochracea und somit ein geringerer Pflanzenbefall mit $V$. longisporum im Biotest nachgewiesen werden. In $10 \mathrm{~cm}$ Eingrabungstiefe wurde in den mit M. ochracea inokulierten Varianten eine geringere rPFL und rSTM im verglichen zur unbehandelten Kontrolle gemessen (Tab. 18).

Tab. 18: Biotest zur Überprüfung des Abbaus von $V$. longisporum auf Rapsstroh durch M. ochracea WG ( $8 \times 10^{6}$ Sporen/ml) in „Litterbagversuchen“ am Standort „Miniplotanlage“ Institutsgarten Göttingen-Weende im Versuchsjahr 2007/2008. Inkubation der Litterbags für 6 Monate in $10 \mathrm{~cm}$ und $20 \mathrm{~cm}$ Bodentiefe; Dargestellt sind Mittelwert und Standardabweichung $(\mathrm{Mw} \pm$ Stabw) von Befallswerten (BW 1-8), relativen Pflanzenlängen (rPFL in \%) und relativen Sprosstrockenmassen (rSTM in \%) der Modellrapspflanzen (RCR); Negativkontrolle mit sterilem Rapsstroh im Biotest (Kontrolle); Probenmaterial aus 10 und $20 \mathrm{~cm}$ Bodentiefe ohne M. ochracea WG (Ms Kontrolle); Probenmaterial aus 10 und $20 \mathrm{~cm}$ Bodentiefe mit M. ochracea WG (Ms + M.o); $\mathrm{n}=4$ (bei 3 technischen WDH); Fisher-Test (LSD) $\mathrm{p} \leq 0,05$.

\begin{tabular}{lccc}
\hline Behandlungsvarianten & BW (1-8) & rPFL (\%) & rSTM (\%) \\
\hline Kontrolle & $1,6 \pm 0,32 \mathrm{~A}$ & $100 \pm 3 \mathrm{a}$ & $100 \pm 11 \alpha$ \\
Ms Kontrolle 10cm & $2,2 \pm 0,43 \mathrm{~B}$ & $84,7 \pm 11 \mathrm{ab}$ & $71,8 \pm 26 \beta$ \\
Ms + M.o 10cm & $2,1 \pm 0,42 \mathrm{AB}$ & $77,1 \pm 13 \mathrm{~b}$ & $59 \pm 19 \beta$ \\
Ms Kontrolle 20 cm & $2,0 \pm 0,27 \mathrm{AB}$ & $81,1 \pm 13 \mathrm{~b}$ & $67,6 \pm 15 \beta$ \\
Ms + M.o 20cm & $2,0 \pm 0,27 \mathrm{AB}$ & $80,8 \pm 8 \mathrm{~b}$ & $72,3 \pm 13 \beta$ \\
\hline
\end{tabular}


Aufgrund des zu geringen Probenmaterials konnten die im Herbst 2007 geborgenen Proben nicht im Biotest überprüft werden, weshalb ein möglicher Abbau des Inokulums von V. longisporum mittels Real-time PCR untersucht wurde.

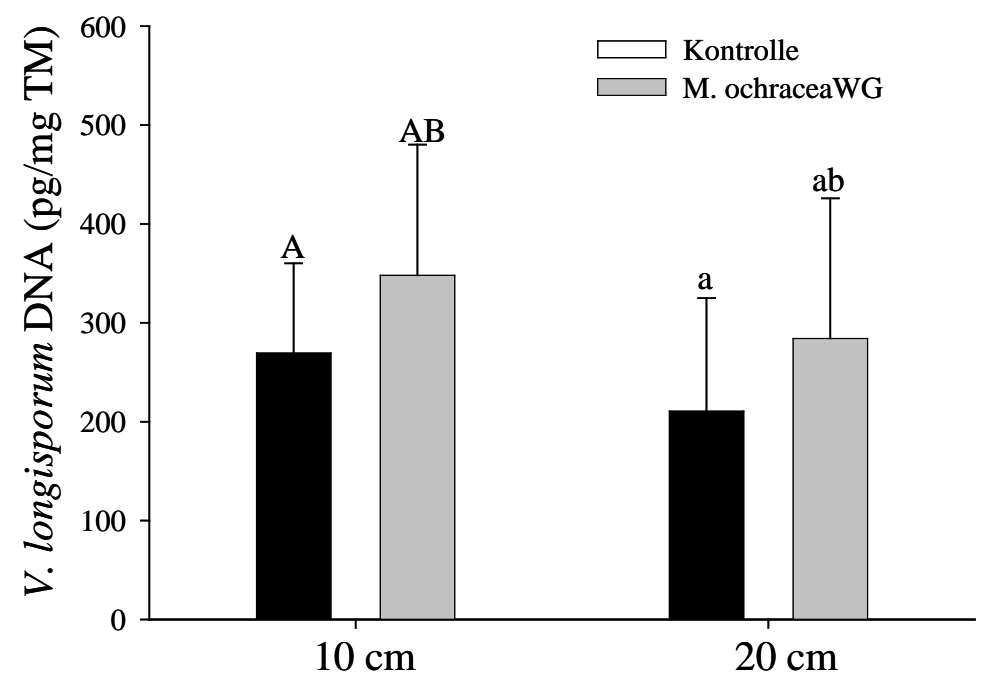

Abb. 26: $V$. longisporum-DNA-Gehalte von mit $V$. longisporum befallenem Rapsstroh nach Behandlung mit M. ochracea WG im Versuchsjahr 2007/2008. Das Rapsstroh wurde mit M. ochracea WG $\left(8 \times 10^{6}\right.$ Sporen/ml) bzw. Wasser inokuliert und für 5 Wochen in $10 \mathrm{~cm}$ und $20 \mathrm{~cm}$ Bodentiefe in Litterbags in der „Miniplotanlage“ Institutsgarten Göttingen-Weende Inkubiert; $n$ = 4; FisherTest (LSD) $\mathrm{p} \leq 0,05$.

In $10 \mathrm{~cm}$ und $20 \mathrm{~cm}$ Eingrabungstiefe wurde in den Proben die mit M. ochracea WG inokuliert waren ein tendenziell höherer V. longisporum-DNA-Gehalt als in den unbehandelten Kontrollen gemessen. Darüber hinaus wurde bei den Kontrollen und den mit M. ochracea WG behandelten Varianten ein tendenziell höherer V. longisporum-DNAGehalt in $10 \mathrm{~cm}$ Eingrabungstiefe im Vergleich zu $20 \mathrm{~cm}$ Eingrabungstiefe festgestellt (Abb. 26).

Aufgrund der Tatsache, dass mit keiner der durchgeführten Untersuchungsmethoden ein Abbau des Inokulums von $V$. longisporum durch $M$. ochracea im Boden nachgewiesen werden konnte, wurde das Probenmaterial (je 3 von 4 Wiederholungen) auf eine Besiedlung mit M. ochracea mittels PCR untersucht. 


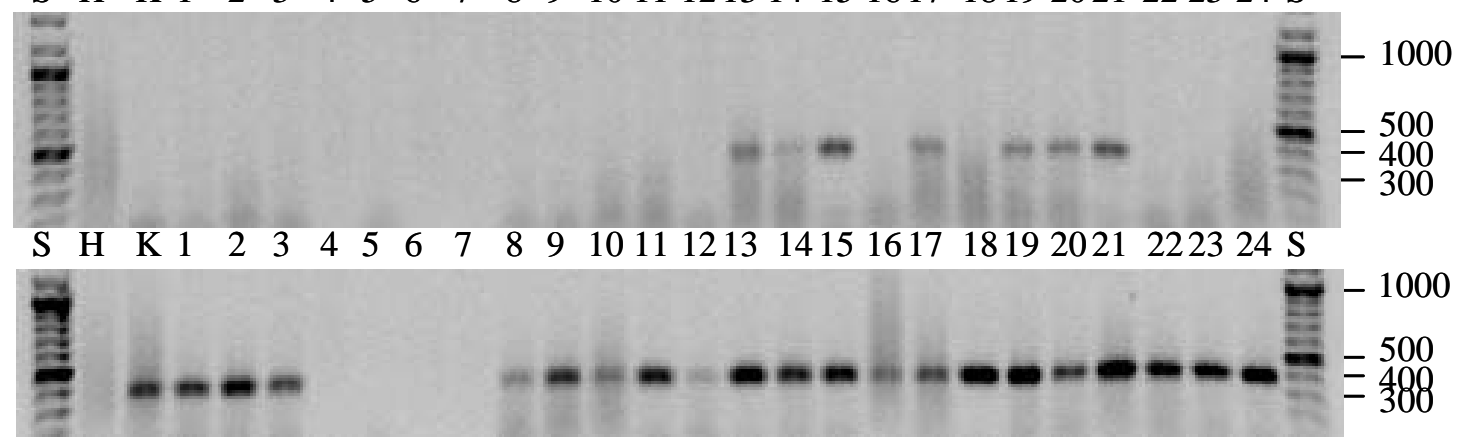

Abb. 27: PCR-Nachweis von $M$. ochracea bei den Interaktionsversuchen zwischen V. longisporum und M. ochracea WG in Litterbags 2007/2008 am Standort „Miniplotanlage“ Institutsgarten Göttingen-Weende. Inkubation der Litterbags für 5 Wochen bzw. 6 Monaten in 10cm bzw. 20cm Bodentiefe; oben: Dargestellt ist der M. ochracea (M.o) PCR-Nachweis bei den im Herbst (He) und Frühsommer (Fr) geborgenen Proben. S: Größenstandard 100bp Leiter Plus; $\mathrm{H}$ : PCR Wasserkontrolle; K: Kontrolle (mit $V$. longisporum befallenes Rapsstroh); 1-3: M.o 10 cm Fr; 4-6: Kontrolle 10cm Fr; 7-9: M.o 20cm Fr; 10-12: Kontrolle 20cm Fr; 13-15: M.o 10cm He; 16-18: Kontrolle 10cm He; 19-21: M.o 20cm He; 22-24: Kontrolle 20cm He; unten: Positivkontrolle (ProbenDNA + 100 pg M. ochracea DNA), H: PCR-Wasserkontrolle ohne M.o DNA, 1,2\%iges Agarosegel.

Die PCR-Untersuchung führte zu einem positiven Nachweis von M. ochracea auf allen mit M. ochracea WG inokulierten und im Herbst 2007 geborgenen Proben (Probe 13, 14, 15 M. ochracea WG 10 cm; Probe 19, 20, 21 M. ochracea WG 20 cm). Darüber hinaus kam es auch zu einem positiven Nachweis von M. ochracea im Probenmaterial einer unbehandelten Kontrolle (Probe 17). Auf den im Frühsommer 2008 geborgenen Proben konnte M. ochracea nicht nachgewiesen werden (Abb.27 oben). Durch die Positivkontrollen konnte außer bei den Proben 4, 5, 6 (Kontrolle $10 \mathrm{~cm} \mathrm{Fr)} \mathrm{und} 7$ (M. ochracea WG 20 cm Fr), eine vollständige Hemmung der PCR-Reaktionen durch PCR-Inhibitoren ausgeschlossen werden (Abb. 27 unten).

Im Versuchsjahr 2008/2009 wurden die Litterbagversuche an zwei Standorten durchgeführt. Anders als im Jahr zuvor wurden die Proben nach der Inokulation mit M. ochracea WG im Labor vorinkubiert und anschließend vergraben. Die Beprobung der Versuche erfolgte ausschließlich im Frühsommer 2009.

Für den Standort „Miniplotanlage“ (Institutsgarten Göttingen-Weende) wurde in dem anschließend im Gewächshaus durchgeführten Biotest in allen Versuchsvarianten ein Befall der Modellrapspflanzen (RCR) mit V. longisporum im Vergleich zur Kontrolle nachgewiesen. Dies zeigte sich in einem erhöhten Befallswert (BW), einer reduzierten 
relativen Pflanzenlänge (rPFL) und geringeren relativen Sprosstrockenmasse (rSTM). Nach einer Behandlung mit M. ochracea WG (8 x $10^{6}$ Sporen/ml), wurden in $10 \mathrm{~cm}$ und $20 \mathrm{~cm}$ Eingrabungstiefe leicht höhere rPFL und rSTM als in den dazugehörigen MsKontrollen gemessen. Eine mit diesen Messdaten übereinstimmende Reduktion des Befallswertes (BW) wurde nur in $20 \mathrm{~cm}$ Eingrabungstiefe festgestellt. Bei diesen Unterschieden handelte es sich lediglich um Tendenzen die statistisch nicht abgesichert werden konnten (Tab. 19).

Tab. 19: Biotest zur Überprüfung des Abbaus von $V$. longisporum auf Rapsstroh durch M. ochracea WG (8x10 ${ }^{4}$ bzw. $8 \times 10^{6}$ Sporen/ml) in „Litterbagversuchen“ am Standort „Miniplotanlage“ Institutsgarten Göttingen-Weende im Versuchsjahr 2008/2009. Inkubation der Litterbags für 6 Monate in $10 \mathrm{~cm}$ und $20 \mathrm{~cm}$ Bodentiefe. Dargestellt sind Mittelwert und Standardabweichung $(\mathrm{Mw} \pm \mathrm{Stabw})$ von Befallswerten (BW 1-8), relativen Pflanzenlängen (rPFL in \%) und relativen Sprosstrockenmassen (rSTM in \%) der Modellrapspflanzen (RCR); Negativkontrolle mit sterilem Rapsstroh im Biotest (Kontrolle); Probenmaterial aus 10 und $20 \mathrm{~cm}$ Bodentiefe ohne M. ochracea WG (Ms Kontrolle); Probenmaterial aus 10 und $20 \mathrm{~cm}$ Bodentiefe mit M. ochracea WG (Ms + M.o); $\mathrm{n}=4$ (bei 3 technischen Wdh); Fisher-Test (LSD) p $\leq 0,05$.

\begin{tabular}{lccc}
\hline Behandlungsvarianten & BW (1-8) & PFL (\%) & STM (\%) \\
\hline Kontrolle & $1,7 \pm 0,47 \mathrm{~A}$ & $100 \pm 3 \mathrm{a}$ & $100 \pm 7 \alpha$ \\
Ms Kontrolle $10 \mathrm{~cm}$ & $2,5 \pm 0,43 \mathrm{~B}$ & $72,8 \pm 10 \mathrm{~b}$ & $62,7 \pm 16 \beta$ \\
Ms + M.o $\left(8 \times 10^{4} \mathrm{Sp} / \mathrm{ml}\right) 10 \mathrm{~cm}$ & $2,2 \pm 0,53 \mathrm{AB}$ & $69,8 \pm 9 \mathrm{~b}$ & $57,8 \pm 7 \beta$ \\
Ms + M.o (8x10 $\mathrm{Sp} / \mathrm{ml}) 10 \mathrm{~cm}$ & $2,6 \pm 0,64 \mathrm{~B}$ & $78,2 \pm 7 \mathrm{~b}$ & $66,8 \pm 12 \beta$ \\
Ms Kontrolle $20 \mathrm{~cm}$ & $2,7 \pm 0,24 \mathrm{~B}$ & $71,2 \pm 9 \mathrm{~b}$ & $57,9 \pm 19 \beta$ \\
Ms + M.o $\left(8 \times 10^{4} \mathrm{Sp} / \mathrm{ml}\right) 20 \mathrm{~cm}$ & $2,5 \pm 0,14 \mathrm{~B}$ & $72,9 \pm 6 \mathrm{~b}$ & $52,4 \pm 9 \beta$ \\
Ms + M.o $\left(8 \times 10^{6} \mathrm{Sp} / \mathrm{ml}\right) 20 \mathrm{~cm}$ & $2,4 \pm 0,50 \mathrm{~B}$ & $77,0 \pm 9 \mathrm{~b}$ & $61,2 \pm 12 \beta$ \\
\hline
\end{tabular}

Im Gegensatz zum Versuchsjahr 2007/2008 konnte M. ochracea nach einer Inokulation mit M. ochracea WG (8 x $10^{6}$ Sporen/ml) bei den im Frühsommer geborgenen Proben nachgewiesen werden. Ein Nachweis erfolgte bei zwei von vier Wiederholungen in $10 \mathrm{~cm}$ Bodentiefe (Proben 2, 3) und bei einer von vier Wiederholungen (Probe 13) in $20 \mathrm{~cm}$ Bodentiefe. Nach der Inokulation von Rapsstängeln mit M. ochracea WG (8 x $10^{4}$ Sporen $/ \mathrm{ml}$ ) wurde M. ochracea weder auf Probenmaterial aus $10 \mathrm{~cm}$, noch aus $20 \mathrm{~cm}$ Bodentiefe nachgewiesen (Abb. 28 oben). Durch die Positivkontrollen konnten vollständige Hemmungen der PCR-Reaktionen, außer bei den Proben 15, 18, 19 und 22, ausgeschlossen werden (Abb. 28 unten). 


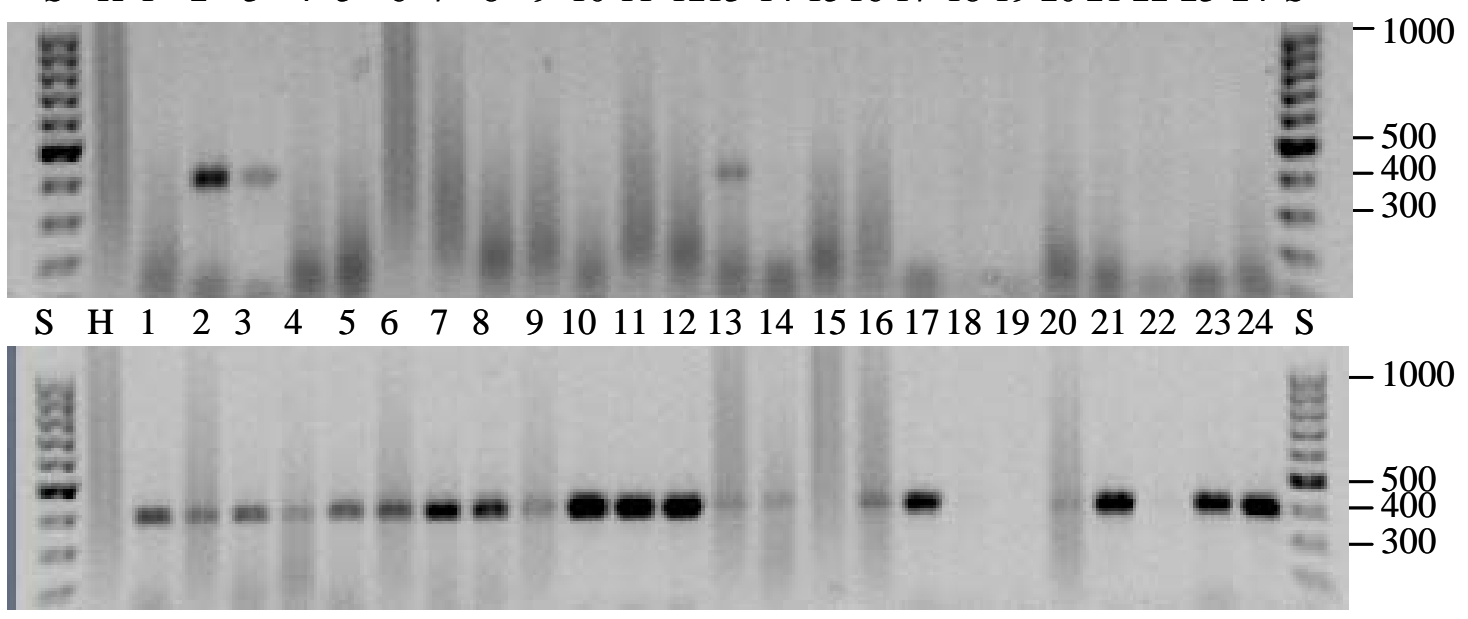

Abb. 28: PCR-Nachweis von $M$. ochracea bei den Interaktionsversuchen zwischen $V$. longisporum und M. ochracea WG in Litterbags am Standort „Miniplotanlage“ Institutsgarten Göttingen-Weende im Versuchsjahr 2008/2009. Inokulation mit M. ochracea WG $\left(8 \times 10^{4}\right.$ bzw. $8 \times 10^{6}$ Sporen $\left./ \mathrm{ml}\right)$ und Inkubation der Litterbags für 6 Monate in $10 \mathrm{~cm}$ bzw. $20 \mathrm{~cm}$ Bodentiefe; oben: Dargestellt ist der PCR-Nachweis von M. ochracea (M.o). S: Größenstandard 100bp Leiter; H: Wasserkontrolle; 1-4: M.o 8x106 Sporen/ml $10 \mathrm{~cm}$; 5-8:

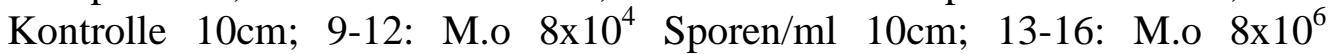
Sporen/ml 20cm; 17-20: Kontrolle 20cm; 21-24: M. o 8x10 4 Sporen/ml 20cm; unten: Positivkontrolle (Proben-DNA + 100 pg M. ochracea DNA) H: PCR Wasserkontrolle ohne M.o DNA; 1,2\%iges Agarosegel.

Im Versuchsjahr 2008/2009 wurde auch für den Standort „Große Breite“ im Biotest bei allen Versuchsvarianten ein Befall der Modellrapspflanzen (RCR) mit V. longisporum nachgewiesen. Im Gegensatz zum Standort „Miniplotanlage“ Institutsgarten GöttingenWeende wurde bei der höheren Inokulationsstufe $\left(8 \times 10^{6}\right.$ Sporen/ml) in $10 \mathrm{~cm}$ und in $20 \mathrm{~cm}$ Bodentiefe eine geringere relative Pflanzenlänge (rPFL) und eine geringere relative Sprosstrockenmasse (rSTM) im Vergleich zu den jeweiligen Ms-Kontrollen gemessen, was auf einen höheren Befall mit $V$. longisporum hinweist. Diese Daten stimmen mit den Befallswerten der Modellpflanzen vom Probenmaterial aus $20 \mathrm{~cm}$ Bodentiefe überein, bei denen ein höherer Befallswert (BW) in der höheren Inokulationsstufe (8 x $10^{6}$ Sporen/ml) mit M. ochracea WG im Vergleich zur MsKontrolle bonitiert wurde. In $10 \mathrm{~cm}$ Bodentiefe konnte ein solcher Zusammenhang nicht nachgewiesen werden. Bei diesen Unterschieden handelt es sich um Tendenzen, die statistisch nicht abgesichert werden können (Tab. 20). 
Tab. 20: Biotest zur Überprüfung des Abbaus von $V$. longisporum auf Rapsstroh durch

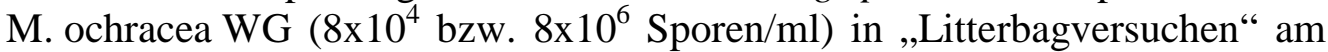
Standort „Große Breite“ Göttingen-Weende im Versuchsjahr 2008/2009. Inkubation für 6 Monate in $10 \mathrm{~cm}$ und $20 \mathrm{~cm}$ Bodentiefe. Dargestellt sind Mittelwert und Standardabweichung von Befallswerten (BW 1-8), relativen Pflanzenlängen (rPFL in \%) und relativen Sprosstrockenmassen (rSTM in \%) der Modellrapspflanzen (RCR); Negativkontrolle mit sterilem Rapsstroh im Biotest (Kontrolle); Probenmaterial aus 10 und $20 \mathrm{~cm}$ Bodentiefe ohne M. ochracea WG (Ms Kontrolle); Probenmaterial aus 10 und $20 \mathrm{~cm}$ Bodentiefe mit M. ochracea WG (Ms + M.o); $\mathrm{n}=4$ (bei 3 technischen WDH); Fisher-Test (LSD) $\mathrm{p} \leq 0,05$.

\begin{tabular}{lccc}
\hline Behandlungsvarianten & BW (1-8) & rPFL (\%) & rSTM (\%) \\
\hline Kontrolle & $3,2 \pm 0,19 \mathrm{~A}$ & $100 \pm 11 \mathrm{a}$ & $100 \pm 9 \alpha$ \\
Ms Kontrolle $10 \mathrm{~cm}$ & $3,8 \pm 0,58 \mathrm{AB}$ & $78,8 \pm 11 \mathrm{~b}$ & $81,6 \pm 10 \beta$ \\
Ms + M.o $\left(8 \times 10^{4} \mathrm{Sp} / \mathrm{ml}\right) 10 \mathrm{~cm}$ & $4,2 \pm 1,29 \mathrm{AB}$ & $82,4 \pm 13 \mathrm{~b}$ & $80,8 \pm 8 \beta$ \\
Ms + M.o $\left(8 \times 10^{6} \mathrm{Sp} / \mathrm{ml}\right) 10 \mathrm{~cm}$ & $3,7 \pm 0,67 \mathrm{AB}$ & $73,1 \pm 4 \mathrm{~b}$ & $76,7 \pm 8 \beta$ \\
Ms Kontrolle $20 \mathrm{~cm}$ & $3,6 \pm 0,32 \mathrm{AB}$ & $81,7 \pm 7 \mathrm{~b}$ & $86,8 \pm 8 \beta$ \\
Ms + M.o $\left(8 \times 10^{4} \mathrm{Sp} / \mathrm{ml}\right) 20 \mathrm{~cm}$ & $4,3 \pm 0,74 \mathrm{~B}$ & $78,7 \pm 5 \mathrm{~b}$ & $74,9 \pm 10 \beta$ \\
Ms + M.o $\left(8 \times 10^{6} \mathrm{Sp} / \mathrm{ml}\right) 20 \mathrm{~cm}$ & $4,2 \pm 0,79 \mathrm{AB}$ & $75,7 \pm 9 \mathrm{~b}$ & $81,3 \pm 7 \beta$ \\
\hline
\end{tabular}

Auch am Standort “Große Breite” wurde M. ochracea auf den im Fühsommer geborgenen Proben nachgewiesen. Die PCR-Untersuchung führte bei zwei $(11,12)$ von vier Proben der niedrigen Inokulationsstufe (8 x 10 $10^{4}$ Sporen/ml) aus $10 \mathrm{~cm}$ Bodentiefe zu einem sehr schwachen aber positiven Nachweis von M. ochracea. Bei Probenmaterial aus $20 \mathrm{~cm}$ Bodentiefe wurde $M$. ochracea bei der hohen Inokulationsstufe $\left(8 \times 10^{6}\right.$ Sporen/ml) in zwei $(13,16)$ von vier Proben nachgewiesen (Abb. 29 oben). Außer bei Probe 12 und 24 der Positivkontrollen konnten vollständige Hemmungen der PCR-Reaktionen ausgeschlossen werden (Abb. 29 unten). 


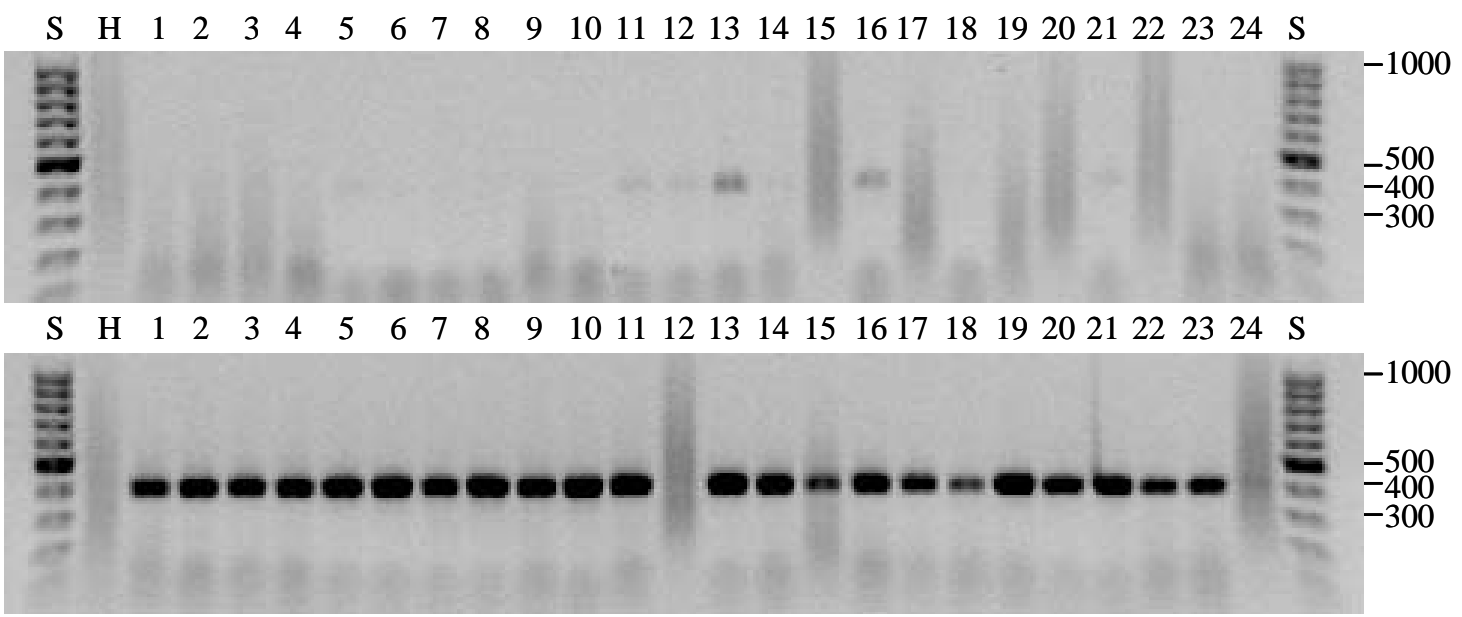

Abb. 29: PCR-Nachweis von $M$. ochracea bei den Interaktionsversuchen zwischen $V$. longisporum und M. ochracea WG in Litterbags am Standort „Große Breite“ Göttingen-Weende 2008/2009. Inokulation mit M. ochracea WG $\left(8 \times 10^{4}\right.$ bzw. $8 \times 10^{6}$ Sporen/ml) und Inkubation für 6 Monaten in $10 \mathrm{~cm}$ bzw. 20cm Bodentiefe; oben: Dargestellt ist der M. ochracea (M.o) PCR-Nachweis. S: Größenstandard 100bp Leiter; H: Wasserkontrolle; 1-4: M.o 8x106 Sporen/ml $10 \mathrm{~cm}$; 5-8: Kontrolle 10cm; 9-12: M.o 8x10 ${ }^{4}$ Sporen $/ \mathrm{ml} \mathrm{10cm;} 13-$ 16: M.o $8 \times 10^{6}$ Sporen/ml 20cm; 17-20: Kontrolle 20cm; 21-24: M. o 8x10 Sporen/ml 20cm; Unten: Positivkontrolle (Proben-DNA + 100 pg M. ochracea DNA) H: PCR Wasserkontrolle ohne M.o DNA; 1,2\%iges Agarosegel.

\subsubsection{Reproduktion von M. ochracea auf Rapsstroh im Freiland}

Um das Wachstum und die Reproduktion von M. ochracea auf Rapsstängeln auf der Bodenoberfläche und in 5 cm Bodentiefe zu untersuchen, wurden im Jahr 2008/2009 Versuche in Litterbags am Standort „Große Breite“ angelegt (vgl. 2.12.2). Nachdem die Proben im Frühsommer 2009 geborgen waren, wurden sie mit Hilfe eines Stereomikroskops auf pilzliche Strukturen hin untersucht. Bei der visuellen Untersuchung der Rapsstängel wurde keine Mikrosklerotienbildung von $V$. longisporum bei den mit $V$. longisporum und M. ochracea koinokulierten Varianten, weder nach Inkubation auf der Bodenoberfläche, noch in $5 \mathrm{~cm}$ Bodentiefe festgestellt. Im Gegensatz dazu wurde auf Rapsstängeln der mit $M$. ochracea inokulierten bzw mit $V$. longisporum und M. ochracea koinokulierten und auf der Bodenoberfläche inkubierten Varianten eine vereinzelte Pyknidienbildung beobachtet. Diese wurden nach dem Überimpfen auf OAMedium und visueller Beurteilung als Pyknidien von M. ochracea identifiziert (nicht dargestellt). 


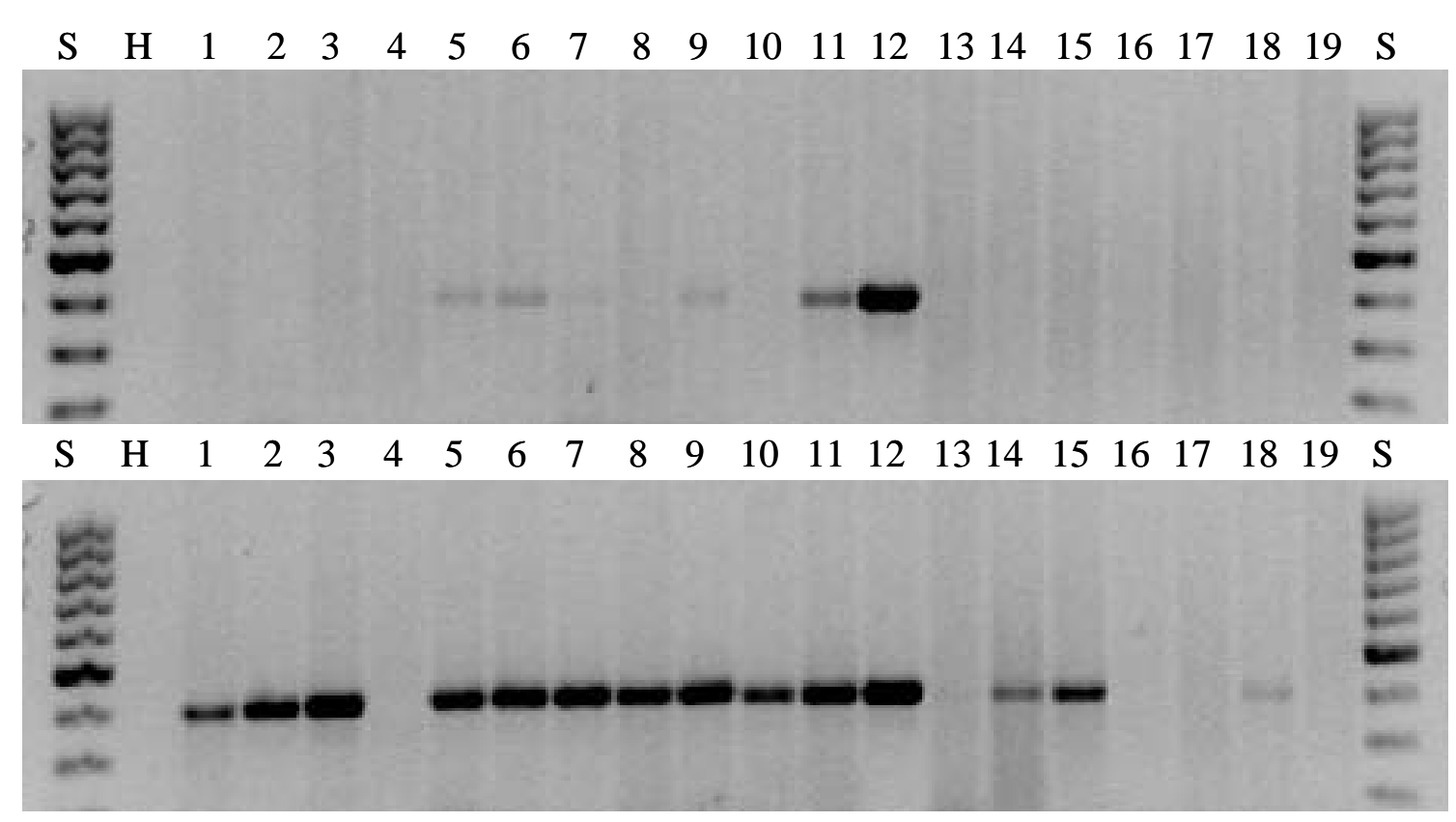

Abb. 30: Nachweis von M. ochracea auf Rapsstängeln mittels PCR. Die Rapsstängel wurden nach Inokulation mit Wasser, $M$. ochracea (M.o) oder V. longisporum und M. ochracea (V.l/M.o) für 9 Monate auf der Bodenoberfläche bzw. in $5 \mathrm{~cm}$ Bodentiefe inkubiert (2008/2009 Standort „Große Breite“). oben: S: Größenstandard 100bp Leiter; H: PCR Wasserkontrolle; 1-2: $\mathrm{H}_{2} \mathrm{O}$ oberfl.; 3-4: $\mathrm{H}_{2} \mathrm{O} 5$ cm; 5-8: V.l/M.o oberfl.; 9-12: M.o oberfl.; 13-15: V.l/M.o 5 cm; 1619: M.o 5 cm; unten: Positivkontrolle (Proben DNA + 100pg M.o DNA), H: PCR Wasserkontrolle ohne M. o DNA ; 1,2\%iges Agarosegel.

Diese Beobachtungen wurden durch PCR-Untersuchungen bestätigt. Ein Nachweis von M. ochracea mittels PCR-Untersuchung erfolgte auf drei von vier Rapsstängelproben (Probe 9, 11, 12), die mit M. ochracea inokuliert und auf der Bodenoberfläche inkubiert wurden. Darüber hinaus wurde M. ochracea mittels PCR-Untersuchung auf zwei von vier Rapsstängelproben (Probe 5, 6) nachgewiesen, die mit V. longisporum und M. ochracea koinokuliert und auf der Bodenoberfläche inkubiert wurden. Für Probe 5, 6 und 9 konnte nur ein schwacher Nachweis erbracht werden, wohingegen in Proben 11 und 12 M. ochracea sicher nachgewiesen wurde. Ein Nachweis von M. ochracea auf den Rapsstängeln, die mit M. ochracea inokuliert bzw. M. ochracea und V. longisporum koinokuliert (Proben 13-19) und in $5 \mathrm{~cm}$ Bodentiefe inkubiert wurden konnte nicht erbracht werden (Abb. 30 oben). Dabei muss berücksichtigt werden, dass es zu einer vollständigen Hemmung bei den PCR-Reaktionen der Proben 13, 16, 17, 19 kam, die in $5 \mathrm{~cm}$ Bodentiefe inkubiert wurden (Abb. 30 unten). 


\subsection{Feldversuche zum Abbau des Pathogeninokulums durch M. ochracea}

\subsubsection{Witterungsverlauf}

In Abb. 31 ist der Witterungsverlauf für die Monate August-September und März-April für die Versuchsjahre 2007/2008 und 2008/2009 des Deutschen Wetterdienstes, Wetterstation Göttingen dargestellt.

Für die Inokulation des Winterrapsmonokulturversuches mit M. ochracea WG am 20.08.2007 waren gute Vorraussetzungen gegeben. M. ochracea WG wurde nach ausreichend Niederschlag in den Tagen zuvor bei ca. $17^{\circ} \mathrm{C}$ Bodentemperatur auf feuchten Boden appliziert und umgehend eingearbeitet. Ein Starkregenereignis am 21.08.07 führte zu einem starken Verschlämmen der Bodenoberfläche und die Aussaat konnte erst am 27.08.2007 bei feuchten Bodenbedingungen erfolgen. Diese führten in zusammen mit Bodentemperaturen von $15-17^{\circ} \mathrm{C}$ zu einem zügigen Auflaufen der Rapssaat.

Die Inokulation des Winterweizenmonokulturversuches und des WinterrapsWinterweizen Fruchtfolgeversuches mit M. ochracea WG erfolgte am 06.09.2007. Nach der Inokulation auf feuchten Boden, direkter Einarbeitung und leichten Niederschlagsereignissen in den folgenden Tagen waren bei Bodentemperaturen von ca. $12-15^{\circ} \mathrm{C}$ gute Vorraussetzungen für das Wachstum von M. ochracea gegeben. Die Aussaat des Winterweizens erfolgte am 24.09.2007. Starkregenereignisse in den folgenden Tagen führten zu einem Verschlämmen der Bodenoberfläche und somit zu einem verzögerten und ungleichmäßigen Auflaufen der Weizensaat.

Die Frühjahrsinokulation des Winterraps- und Winterweizenmonokulturversuches mit M. ochracea WG erfolgte am 02.04.2008 bei einer hohen Feuchtigkeit in den Beständen und Bodentemperaturen von ca. $8^{\circ} \mathrm{C}$. Durch täglich leichte Niederschlagsereignisse und Bodentemperaturen von $5-8^{\circ} \mathrm{C}$ in den folgenden Tagen waren gute Vorraussetzungen für das Wachstum von M. ochracea gegeben. 
Aug-Sept. 2007

März-April 2008
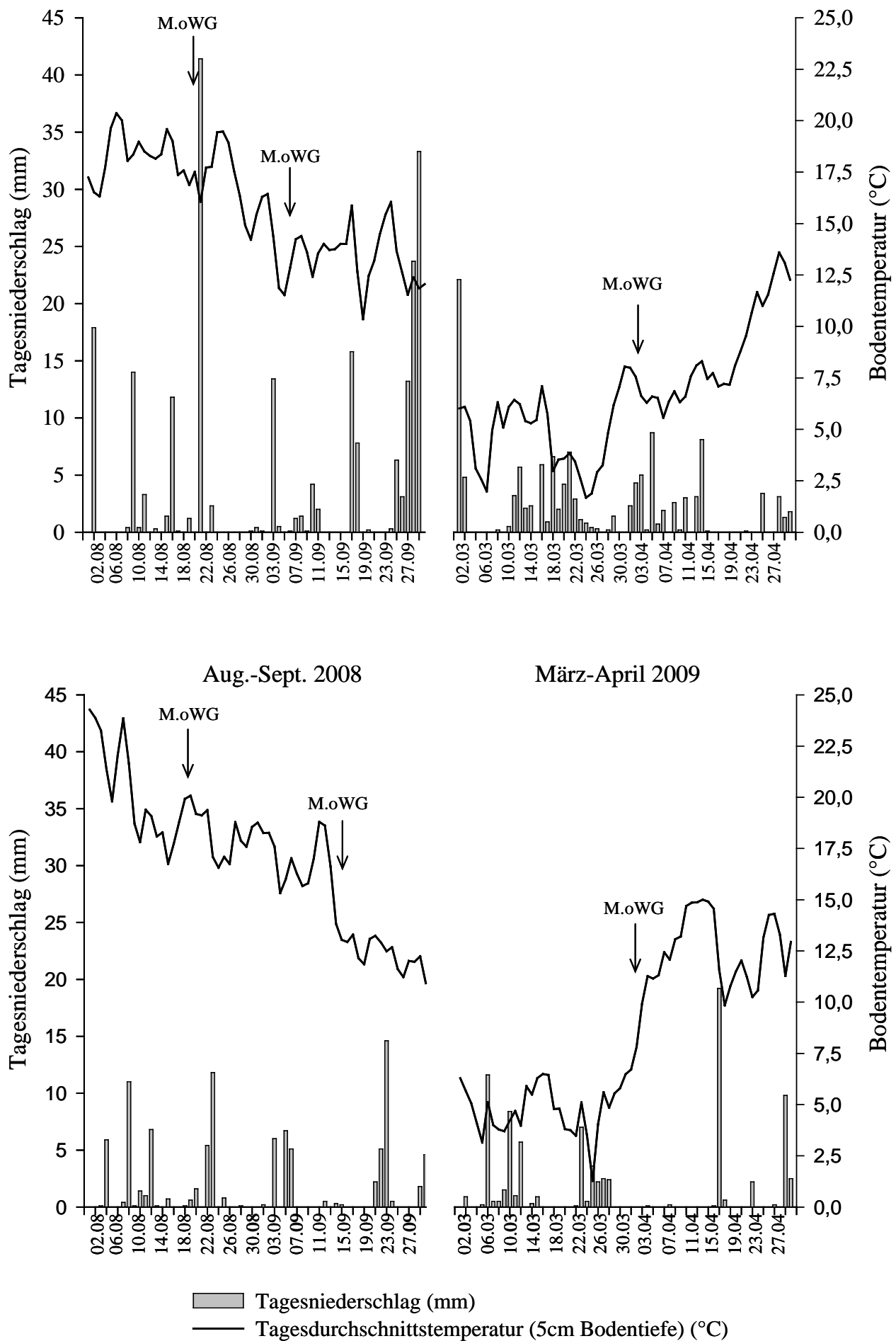

Abb. 31: Tägliche Niederschlagsmengen (mm) und Tagesdurchschnittstemperaturen $\left({ }^{\circ} \mathrm{C}\right)$ in $5 \mathrm{~cm}$ Bodentiefe. Eingezeichnet sind die Inokulationstermine mit M. ochracea WG. Oben: Versuchszeitraum August-September 2007 und März-April 2008; unten: Versuchszeitraum August-September 2008 und März-April 2009; basierend auf Daten des DWD, Wetterstation Göttingen.

Im Sommer 2008 erfolgte die Herbstinokulation des Winterrapsmonokulturversuches und des Winterweizen-Winterraps Fruchtfolgeversuches mit M. ochracea WG am 
18.08.2008. Nach der Applikation auf feuchten Boden bei Bodentemperaturen von ca. $20^{\circ} \mathrm{C}$ wurde $M$. ochracea umgehend eingearbeitet. Die Aussaat von Winterraps erfolgte am gleichen Tag. Leichter Niederschlag in den folgenden Tagen bei Bodentemperaturen von $16-20^{\circ} \mathrm{C}$ boten optimale Vorraussetzungen für M. ochracea, und führten zu einem schnellen Keimen und Auflaufen der Rapssaat.

Für die Herbstinokulation des Winterweizenmonokulturversuches waren suboptimale Voraussetzungen gegeben. Nach geringen Niederschlägen an den Tagen zuvor wurde M. ochracea WG am 15.09.2008 appliziert und direkt eingearbeitet. Die Winterweizenaussaat erfolgte am 15.10.2008. Aufgrund abfallender Temperaturen und ausbleibendem Niederschlag kam es zu einem verzögerten und ungleichmäßigem Auflaufen der Weizensaat (Wetterdaten sind nicht dargestellt).

Die Frühjahrsinokulation aller 3 Versuche mit M. ochracea WG erfolgte am 02.04.2009. Aufgrund vorausgegangenen Niederschlagsereignissen waren optimale Feuchtigkeitsbedingungen bei Bodentemperaturen von ca. $8^{\circ} \mathrm{C}$ für die Inokulation mit M. ochracea WG gegeben. Aufgrund ausbleibender Niederschläge in den folgenden 14 Tagen, zusammen mit steigenden Bodentemperaturen bis $15^{\circ} \mathrm{C}$, kam es zu einem Abtrocknen der Bestände und somit zu suboptimalen Wachstumsbedingungen für M. ochracea.

\subsubsection{Einfluss von M. ochracea auf den pilzlichen Pathogenbefall im Winterweizen Monokulturanbau}

Im Rahmen des Winterweizenmonokulturversuchs wurde ein möglicher Abbau des Inokulums von D. tritici-repentis (DTR) und S. tritici durch M. ochracea und deren Auswirkung auf den Befall des Winterweizens mit den beiden Schadpathogenen in den Jahren 2008 und 2009 am Standort Göttingen untersucht. Die Befallsbonitur wurde im Jahr 2008 in BBCH 51 (27.05.2008) und BBCH 75 (23.06.2008) durchgeführt. Im Jahr 2009 erfolgte die Befallsbonitur in BBCH 61 (02.06.2009) und BBCH 75 (29.06.2009). Zur visuellen Befallserfassung wurden alle vitalen Blattetagen herangezogen auf denen die Blattsympthome von DTR und S. tritici eindeutig identifiziert und differenziert werden konnten. 


\subsubsection{Befall mit $D$. tritici-repentis}

Im Jahr 2008 wurde zum Boniturtermin BBCH 51 (27.05.2008) nur ein sehr geringer Blattbefall mit DTR ermittelt. Aufgrund des geringen Befallsgeschehens $(<1 \%)$ wurde auf eine statistische Verrechnung und Interpretation der Daten verzichtet. In BBCH 75 (23.06.2008) wurde ein mittelhoher Blattbefall mit DTR bonitiert. Dieser lag mit durchschnittlich 25\% befallener Blattfläche auf F-2 deutlich höher als auf F-1 mit durchschnittlich 9\% befallener Blattfläche. Herbstbehandlungen und HerbstFrühjahrsbehandlungen mit M. ochracea WG führten bei keiner Behandlungsvariante zu einer Reduktion des Befallsdrucks mit DTR im Vergleich zur unbehandelten Kontrolle. Eine zweimalige Fungizidbehandlung der Fungizidvariante in BBCH 29 und BBCH 39 führten hingegen zu einer signifikanten Reduktion des DTR-Befalls (Abb. 32).

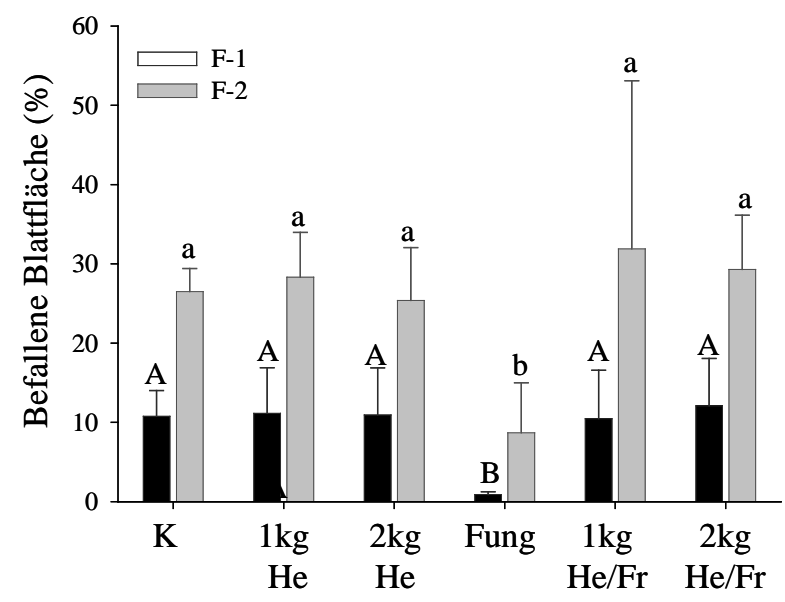

Abb. 32: Blattbefall von Winterweizen mit DTR im Winterweizenmonokulturversuch am Standort „Große Breite“ Göttingen-Weende im Versuchsjahr 2007/2008. Dargestellt ist die DTR-Befallsstärke (\%) an F-1 und F-2 an der Winterweizensorte Paroli in BBCH 75. Behandlungsvarianten: Kontrolle (K); Fungizidvariante (Fung); mit M. ochracea WG behandelte Varianten $1 \mathrm{~kg} / \mathrm{ha}$ Herbst (1kgHe), 2 kg/ha Herbst (2kgHe), 1 kg/ha Herbst-Frühjahr (1kgHe/Fr), 2 kg/ha Herbst-Frühjahr (2kgHe/Fr); $n=4$; Fisher-Test (LSD); $\mathrm{p} \leq 0,05$.

Im Versuchsjahr 2009 kam es zu einem deutlich stärkeren DTR-Befall als 2008. In BBCH 61 (02.06.2009) wurde auf F-3 (durchschnittlich 32\% befallene Blattfläche) ein höherer DTR-Befall als auf F-2 (durchschnittlich 15\% befallene Blattfläche) bonitiert. Durch eine kombinierte Behandlung mit 1 kg/ha, bzw. 2 kg/ha M. ochracea WG im Herbst und im Frühjahr konnte der DTR-Befall auf F-3 und F-2 um durchschnittlich 6,5\% und 3,8\% im Vergleich zur unbehandelten Kontrolle reduziert werden. Auch durch eine einmalige Behandlung mit $2 \mathrm{~kg} / \mathrm{ha}$ M. ochracea WG im Herbst wurde der 
DTR-Befall auf F-3 reduziert. Diese Befallsunterschiede beruhen auf tendenziellen Unterschieden, die statistisch nicht abgesichert werden konnten. Der geringste DTRBefall wurde in der Fungizidvariante bonitiert. Durch eine zweimalige Fungizidbehandlung in BBCH 27 und BBCH 37/39 konnte der DTR-Befall auf F-3 und F-2 signifikant, im Vergleich zur unbehandelten Kontrolle und den mit M. ochracea WG behandelten Varianten, reduziert werden (Abb. 33 links).
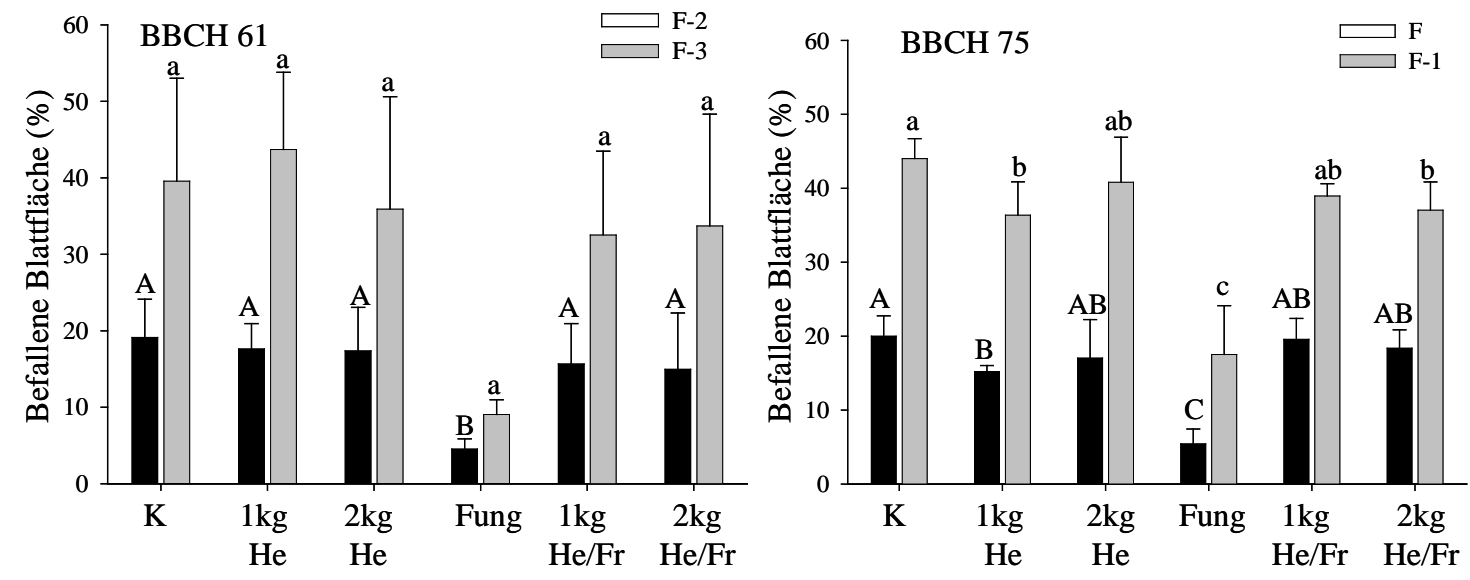

Abb. 33: Blattbefall von Winterweizen mit DTR im Winterweizenmonokulturversuch am Standort „Große Breite“ Göttingen-Weende im Versuchsjahr 2008/2009. Dargestellt ist die DTR-Befallsstärke (\%) an F-2 und F-3 in BBCH 61 (links) und an F und F-1 in BBCH 75 (rechts) an der Winterweizensorte Paroli. Behandlungsvarianten: Kontrolle (K); Fungizidvariante (Fung); mit M. ochracea WG behandelte Varianten $1 \mathrm{~kg} / \mathrm{ha}$ Herbst (1 kgHe), $2 \mathrm{~kg} / \mathrm{ha}$ Herbst (2kgHe), 1 kg/ha Herbst-Frühjahr (1kgHe/Fr), 2 kg/ha Herbst-Frühjahr $(2 \mathrm{kgHe} / \mathrm{Fr}) ; \mathrm{n}=4$; Fisher-Test (LSD) $\mathrm{p} \leq 0,05$.

Zum zweiten Boniturtermin in BBCH 75 (29.06.2009) wurde auf F und F-1 eine DTRBefallsstärke von durchschnittliche $16 \%$ und 36\% befallener Blattfläche bonitiert. Durch eine einmalige Behandlung im Herbst mit $1 \mathrm{~kg} / \mathrm{ha}$ und eine kombinierte Behandlung im Herbst und im Frühjahr mit 2 kg/ha M. ochracea WG wurden auf F-1 ein um durchschnittlich 7,3 \% signifikant niedrigerer DTR-Befall als in der unbehandelten Kontrolle bonitiert. Auch auf F wurde der DTR-Befall durch eine Herbstbehandlung mit $1 \mathrm{~kg} / \mathrm{ha}$ M. ochracea WG signifikant im Vergleich zur unbehandelten Kontrolle reduziert.

Darüber hinaus konnte der DTR-Befall auf F-1 durch eine einmalige Behandlung im Herbst mit 2 kg/ha M. ochracea WG und eine kombinierte Behandlung im Herbst und im Frühjahr mit $1 \mathrm{~kg} / \mathrm{ha}$ M. ochracea WG tendenziell im Vergleich zur Kontrolle reduziert werden. Eine ähnliche Tendenz wurde auch auf F in der im Herbst mit 2 kg/ha 
M. ochracea WG behandelten Variante beobachtet. Der geringeste Befall mit DTR trat in der Fungizidvariante auf. Durch eine dreimalige Fungizidbehandlung in BBCH 27, BBCH 37/39 und BBCH 69 trat auf F und F-1 der Fungizidvariante ein signifikant niedrigerer DTR-Befall als in der Kontrolle und den mit M. ochracea WG behandelten Varianten auf (Abb. 33 rechts).

\subsubsection{Befall mit S. tritici}

Im Jahr 2008 kam es in BBCH 51 nur zu einem geringen Befall mit S. tritici. Aufgrund des geringen Befallsniveaus auf den jüngeren Blättern ( $<1 \%$ befallene Blattfläche), der starken Blattverbräunung und durch den natürlichen Alterungsprozess der älteren Blätter konnte eine eindeutige Befallserfassung und Differenzierung von S.tritici in BBCH 51 nur auf F-4 durchgeführt werden.

Durch eine einmalige Behandlung mit 1 kg/ha bzw. 2 kg/ha M. ochracea WG im Herbst wurde der Befall mit S. tritici auf F-4 tendenziell um durchschnittlich 0,5\% im Vergleich zur Kontrolle reduziert. Auch durch eine zweimalige Behandlung mit $2 \mathrm{~kg} / \mathrm{ha}$ M. ochracea WG konnte der Befall um tendenziell 1,6\% im Vergleich zur Kontrolle reduziert werden. Der geringste Befall mit S. tritici trat in der Fungizidvariante auf. Durch eine zweimalige Fungizidbehandlung in BBCH 29 und BBCH 39 wurde der Befall signifikant um 2,8\% im Vergleich zur Kontrolle reduziert (Abb. 34 links).
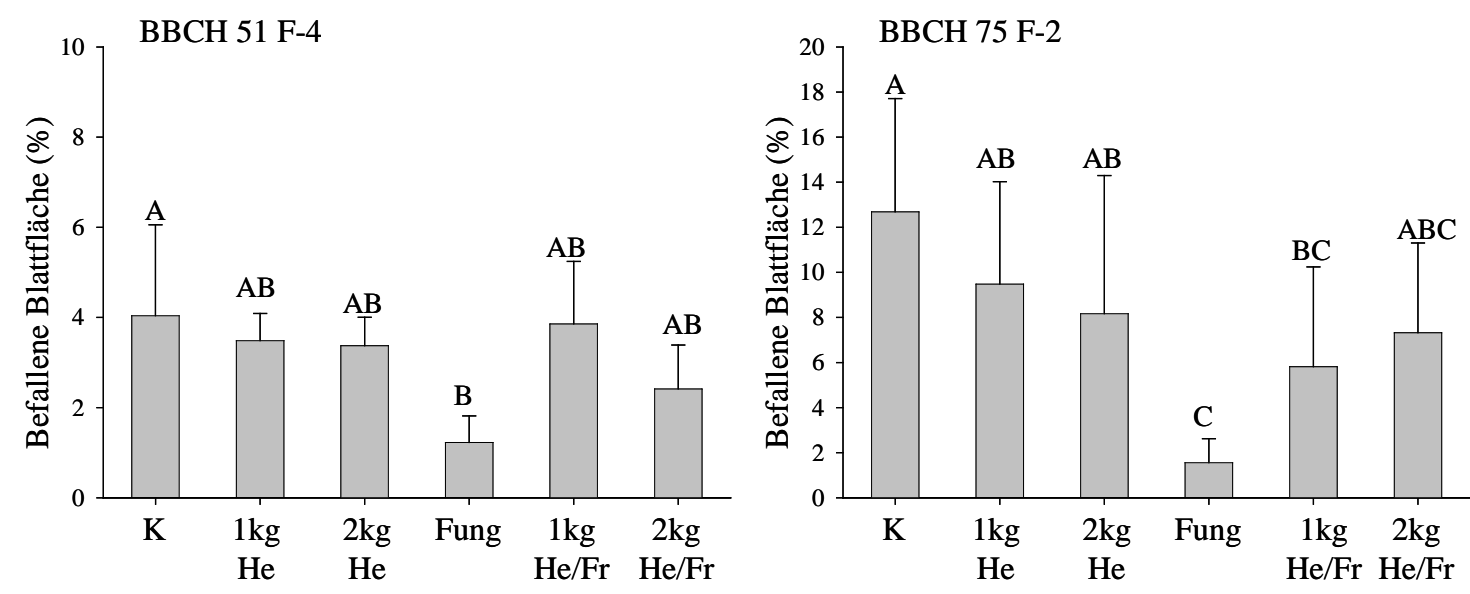

Abb. 34: Blattbefall von Winterweizen mit S. tritici im Winterweizenmonokulturversuch am Standort „Große Breite“ Göttingen-Weende im Versuchsjahr 2007/2008. Dargestellt ist die mittlere S. tritici-Befallsstärke (\%) an der Winterweizensorte Paroli in BBCH 51 an F-4 (links) und BBCH 75 an F-2 (rechts). Behandlungsvarianten: unbehandelte Kontrolle (K); Fungizidvariante (Fung); mit M. ochracea WG behandelte Varianten 1 kg/ha Herbst (1kgHe), 2 kg/ha Herbst (2kgHe), 1 kg/ha Herbst-Frühjahr (1kgHe/Fr) und 2 kg/ha Herbst-Frühjahr (2kgHe/Fr); $n=4$; Fisher-Test (LSD) $\mathrm{p} \leq 0,05$. 
In BBCH 75 (23.06.08) konnte eine eindeutige Befallsbonitur und Identifizierung von S. tritici nur auf F-2 durchgeführt werden. Aufgrund des geringen Befallsgeschehens auf F und F-1 wurde auf eine statistische Auswertung und Interpretation der Daten verzichtet.

Durch eine Behandlung mit 1 kg/ha und 2 kg/ha M. ochracea WG im Herbst wurde der Befall mit S. tritici auf F-2 tendenziell um 3,2\% und 4,5\% im Vergleich zur Kontrolle reduziert. Durch kombinierte Behandlungen mit M. ochracea WG im Herbst und im Frühjahr wurden bessere Befallsreduktionen im Vergleich zu den Einmalbehandlungen erzielt. Dabei konnte durch eine kombinierte Behandlung mit 1 kg/ha M. ochracea WG der S. tritici-Befall signifikant um 6,9\%, und durch eine kombinierte Behandlung mit $2 \mathrm{~kg} / \mathrm{ha}$ M. ochracea WG tendenziell um 5,4\% im Vergleich zur unbehandelten Kontrolle reduziert werden. Der geringste Befall mit S.tritici wurde in der Fungizidvariante bonitiert. Durch zweimalige Fungizidbehandlungen in BBCH 29 und BBCH 39 wurde der Befall auf F-2 signifikant im Vergleich zur Kontrolle und den im Herbst mit M. ochracea WG behandelten Varianten reduziert (Abb. 34 rechts).

Im Jahr 2009 wurde zu beiden Boniturterminen ein sehr geringer Befall mit S. tritici bonitiert. Aufgrund des geringen Befalls (<1\%) wurde auf eine statistische Auswertung der Daten verzichtet.

\subsubsection{Auswirkungen auf den Kornertrag}

Im Jahr 2008 wurde durch Behandlungen mit M. ochracea WG kein Mehrertrag erzielt. Der Kornertrag lag im Durchschnitt der Varianten, die mit M. ochracea WG behandelt wurden und der unbehandelten Kontrollvariante bei 60,7 dt/ha. Nur in der Fungizidvariante wurde durch eine zweimalige Fungizidbehandlung ein signifikanter Mehrertrag von 6,5 dt/ha im Vergleich zum Durchschnittsertrag der übrigen Behandlungsvarianten ermittelt (Abb. 35 links). 

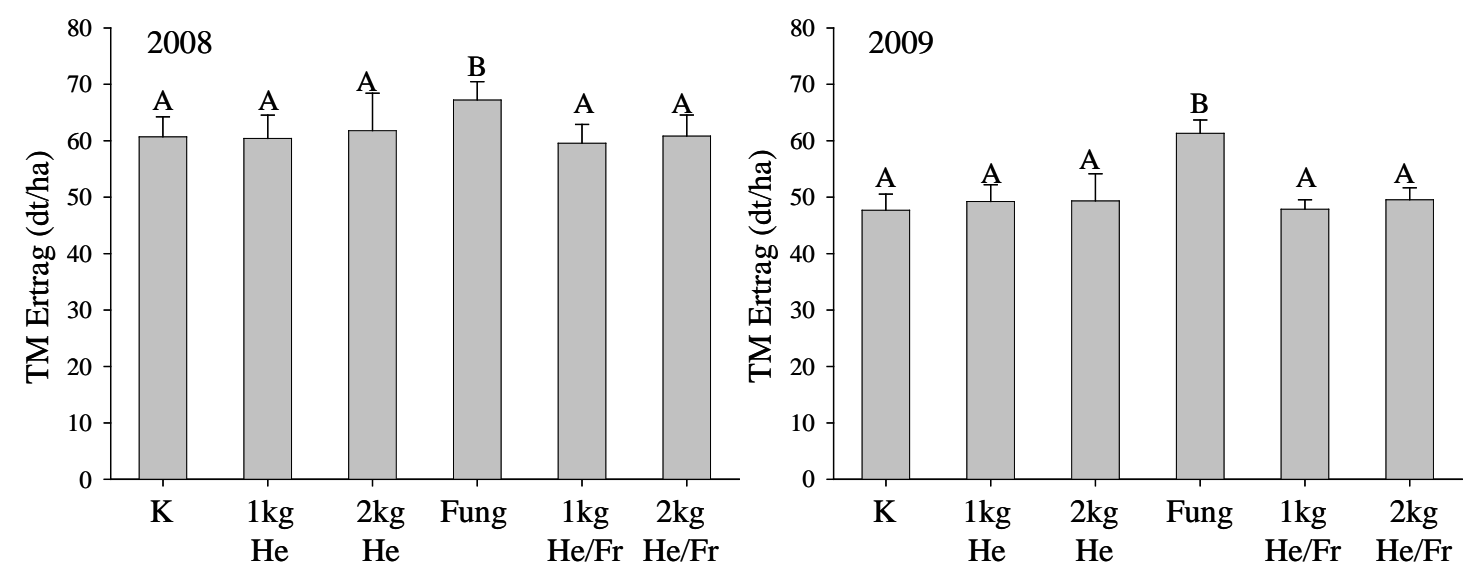

Abb. 35: Kornertrag von Winterweizen im Winterweizenmonokulturversuch (Sorte Paroli) am Standort „Große Breite“ Göttingen-Weende 2007/2008 (links) und 2008/2009 (rechts). Dargestellt ist der Trockenmassekornertrag in der unbehandelten Kontrolle (K), der Fungizidvariante (Fung) und den mit M. ochracea WG behandelten Varianten $1 \mathrm{~kg} / \mathrm{ha}$ Herbst (1kgHe), $2 \mathrm{~kg} / \mathrm{ha}$ Herbst (2kgHe), $1 \mathrm{~kg} / \mathrm{ha}$ Herbst-Frühjahr (1kgHe/Fr) und $2 \mathrm{~kg} / \mathrm{ha}$ HerbstFrühjahr (2kgHe/Fr); $n=4$; Fisher-Test (LSD) $\mathrm{p} \leq 0,05$.

Im Jahr 2009 wurde im Durchschnitt der Varianten, die mit M. ochracea WG behandelt wurden und der Kontrollvariante, ein Ertrag von 48,7 dt/ha erzielt. Somit lag das Ertragsniveau um 12 dt/ha unter dem Ertragsniveau des Vorjahres. Es wurde bei den mit $1 \mathrm{~kg} / \mathrm{ha}, 2 \mathrm{~kg} / \mathrm{ha}$ M. ochracea WG im Herbst behandelten Varianten und der Doppelbehandlung mit 2 kg/ha M. ochracea WG im Herbst und im Frühjahr ein Mehrertrag von 1,5, 1,6, bzw. 1,8 dt/ha im Vergleich zur unbehandelten Kontrollvariante (47,7 dt/ha) erzielt, dieser konnte statistisch aber nicht abgesichert werden. Es wurde ausschließlich in der Fungizidvariante durch dreimalige Fungizidbehandlungen ein signifikanter Mehrertrag von 12,6 dt/ha im Vergleich zum Durchschnittsertrag (48,7 dt/ha) aller übrigen Varianten geerntet (Abb. 35 rechts).

\subsubsection{Einfluss von M. ochracea auf den Pathogenbefall im Winterraps Monokulturanbau.}

Im Rahmen des Winterrapmonokulturversuches wurde ein möglicher Abbau des Inokulums von P. lingam und $V$. longisporum durch $M$. ochracea und die Auswirkungen auf den Befall von Winterraps in den Versuchsjahren 2007/2008 und 2008/2009 am Standort Göttingen untersucht. 


\subsubsection{Befall mit $P$. lingam}

Bereits im Herbst 2007 wurde ein massives Auftreten von P. lingam beobachtet. Neben einem starken Blattbefall trat ein starker Wurzelhalsbefall mit einer durchschnittlichen Befallshäufigkeit von 47,9\% auf, der zu vereinzelten Pflanzenausfällen führte.

Zum Boniturtermin in BBCH 80 (24.06.2008) wurde eine mittlere Befallsstärke von $P$. lingam an Wurzelhals und Stängel bonitiert. Durch Behandlungen mit $1 \mathrm{~kg} / \mathrm{ha}$ und $2 \mathrm{~kg} / \mathrm{ha}$ M. ochracea WG im Herbst wurde der Wurzelhalsbefall mit P. lingam im Vergleich zur Kontrolle reduziert, wobei mit der höheren Aufwandmenge deutlich bessere Befallsreduktionen erzielt wurden. Auch durch kombinierte Behandlungen mit 1 kg/ha und 2 kg/ha M. ochracea WG im Herbst und im Frühjahr wurde eine Reduktion des Wurzelhalsbefalls auf das Niveau der 2 kg/ha Herbstbehandlung erzielt. Durch Behandlungen mit M. ochracea WG wurde der Stängelbefall mit P. lingam, mit Ausnahme in der 2 kg/ha Herbstbehandlung, reduziert. Das Befallsniveau lag in diesen Versuchsvarianten leicht unter dem des Wurzelhalsbefalls. Der geringste Befall mit P. lingam trat in der Fungizidvariante auf. Durch zweimalige Fungizidbehandlungen in BBCH 16 und BBCH 59 wurde der Wurzelhalsbefall signifikant im Vergleich zur Kontrolle, und der Stängelbefall signifikant im Vergleich zur Kontrolle und den mit $1 \mathrm{~kg} / \mathrm{ha}$ und 2 kg/ha M. ochracea WG im Herbst behandelten Varianten reduziert (Abb. 36 links).
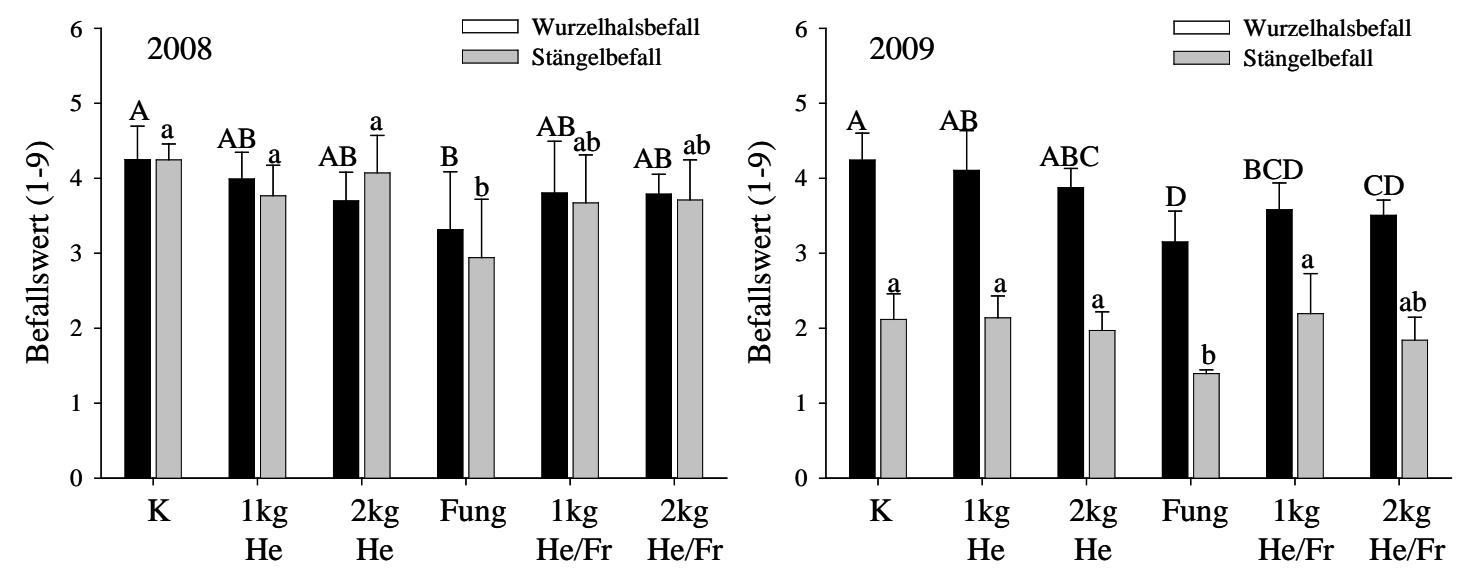

Abb. 36: Befall der Rapspflanzen mit P. lingam im Winterrapsmonokulturversuch am Standort „Große Lage“ Göttingen-Weende in den Versuchsjahren 2007/2008 (links) und 2008/2009 (rechts). Dargestellt ist der mittlere P. lingam-Befallswert (1-9) in BBCH 80 an der Winterrapssorte Trabant; Behandlungsvarianten: unbehandelten Kontrolle (K); Fungizidvariante (Fung); mit M. ochracea WG behandelte Varianten $1 \mathrm{~kg} / \mathrm{ha}$ Herbst (1 kgHe), $2 \mathrm{~kg} / \mathrm{ha}$ Herbst (2kgHe), $1 \mathrm{~kg} / \mathrm{ha}$ Herbst-Frühjahr (1kgHe/Fr) und 2 kg/ha Herbst-Frühjahr $(2 \mathrm{kgHe} / \mathrm{Fr}) ; \mathrm{n}=4$; Fisher-Test (LSD) $\mathrm{p} \leq 0,05$. 
Im Herbst 2008 wurde nur ein sehr geringer Befall mit P. lingam an Blättern und Wurzelhals beobachtet.

Zum Boniturtermin BBCH 80 (03.07.2009) wurde in der Kontrolle ein ähnlich hoher Befall des Wurzelhalses mit P. lingam wie im Jahr 2008 bonitiert. Der Stängelbefall lag hingegen in der Kontrolle und allen Behandlungsvarianten, verglichen mit 2008 auf einem deutlich geringeren Befallsniveau. Durch Behandlung mit 1 kg/ha und $2 \mathrm{~kg} / \mathrm{ha}$ M. ochracea WG im Herbst wurde der Wurzelhalsbefall im Vergleich zur Kontrolle reduziert. Mit der höheren Aufwandmenge wurden deutlich bessere Befallsreduktionen erzielt. Durch eine kombinierte Behandlung mit $1 \mathrm{~kg} / \mathrm{ha}$ M. ochracea WG im Herbst und im Frühjahr wurde der Wurzelhalsbefall mit $P$. lingam signifikant im Vergleich zur Kontrolle, und in einem statistisch nicht absicherbaren Maße zu den mit $1 \mathrm{~kg} / \mathrm{ha}$ und 2 kg/ha M. ochracea WG im Herbst behandelten Varianten reduziert. Noch bessere Befallsreduktionen wurden durch Doppelbehandlungen mit 2 kg/ha M. ochracea WG im Herbst und im Frühjahr erzielt. In dieser Behandlungsvariante trat ein signifikant geringerer Wurzelhalsbefall auf, verglichen mit der Kontrolle und der mit $1 \mathrm{~kg} / \mathrm{ha}$ im Hebst behandelten Variante. Aufgrund des geringen Befallsgeschehens am Stängel mit $P$. lingam wurden keine eindeutigen Befallsreduktionen durch Behandlungen mit M. ochracea WG festgestellt.

Der geringste Befall mit P. lingam trat im Jahr 2009 wiederum in der Fungizidvariante auf. Durch zweimalige Fungizidbehandlungen in BBCH 50 und BBCH 63 wurde der Wurzelhalsbefall signifikant im Vergleich zur Kontrolle und den mit $1 \mathrm{~kg} / \mathrm{ha}$ und $2 \mathrm{~kg} / \mathrm{ha}$ M. ochracea WG im Hebst behandelten Varianten reduziert. Im Vergleich zu den Doppelbehandlungen mit M. ochracea WG im Herbst und im Frühjahr waren hingegen nur tendenzielle Befallsreduktionen $\mathrm{zu}$ erkennen. Durch Fungizidbehandlungen wurde der P. lingam-Stängelbefall signifikant im Vergleich zur Kontrolle, und den mit 1 kg/ha, 2 kg/ha M. ochracea WG im Herbst und der mit 1kg/ha im Herbst und im Frühjahr behandelten Varianten reduziert. Im Vergleich zur Doppelbehandlung mit 2 kg/ha M. ochracea WG im Herbst und im Frühjahr wurde hingegen nur eine tendenzielle Befallsreduktion festgestellt (Abb. 36 rechts).

\subsubsection{Befall mit $V$. longisporum}

Im Jahr 2008 wurde bei allen Behandlungsvarianten ein schwacher Befall der Rapsstoppeln mit $V$. longisporum bonitiert. Der geringste Verticillium-Befall trat in der 
Kontrolle und der Doppelbehandlung mit 2 kg/ha M. ochracea WG im Herbst und im Frühjahr auf. Die Rapspflanzen der übrigen Varianten waren stärker mit V. longisporum befallen (Abb. 37 links).

Im Jahr 2009 konnte aufgrund des folgenden Aussaattermins nicht bis zum vollständigen Abreifen der Rapsstoppeln gewartet werden, weshalb die visuelle Befallserfassung von $V$. longisporum teilweise an grünen Rapsstoppeln durchgeführt werden musste. In diesem Jahr wurde in allen Behandlungsvarianten ein schwächerer Befall mit V. longisporum, verglichen mit 2008, beobachtet. Der höchste Verticillium-Befall wurde in der Fungizidvariante ermittelt. In den übrigen Varianten wurden keine Befallsunterschiede festgestellt (Abb. 37 rechts). Aufgrund der ungünstigen Rahmenbedingungen (grüne Stoppeln), die zu möglichen Falschaussagen führen könnten, wurden während der Probenahme gleichzeitig Stoppelproben für Real-time PCR Untersuchungen entnommen. Damit sollten mögliche Unterschiede in den DNA-Gehalten von $V$. longisporum in der Pflanzentrockenmasse ermittelt werden.
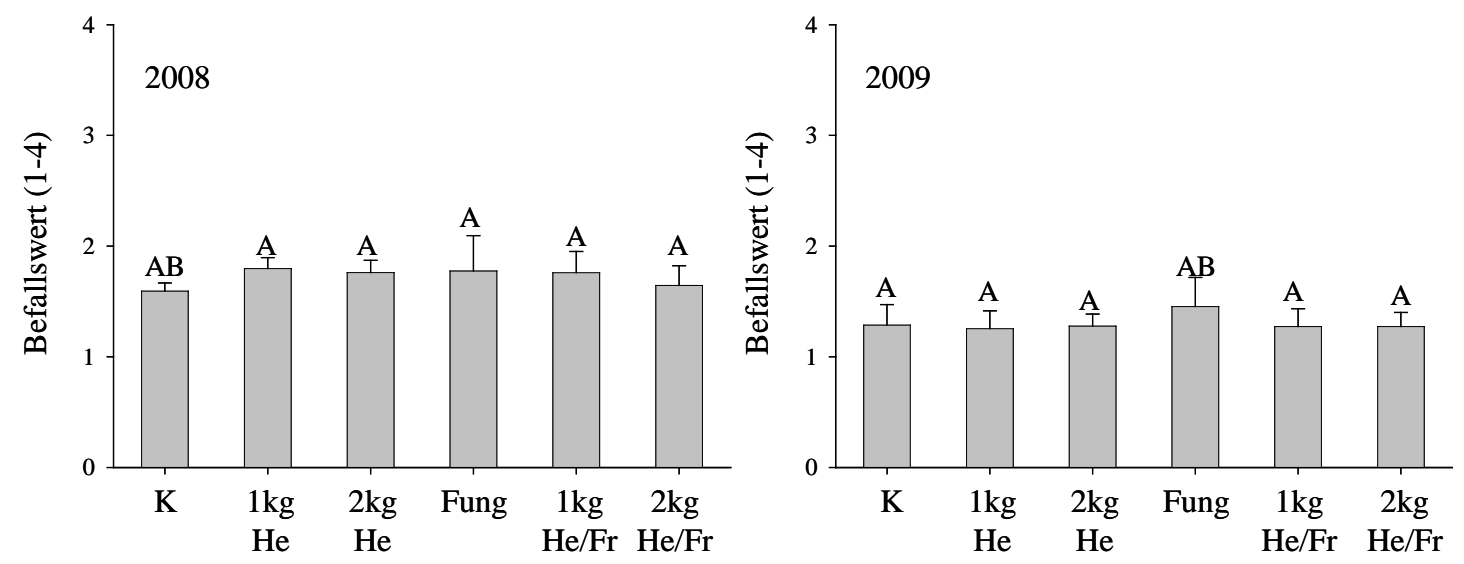

Abb. 37: Befall der Rapspflanzen mit $V$. longisporum im Winterrapsmonokulturversuch (Sorte Trabant) am Standort „Große Lage“ GöttingenWeende im Versuchsjahr 2007/2008 (links) und 2008/2009 (rechts). Dargestellt ist der mittlere Befallswert (1-4) in der unbehandelten Kontrolle (K), der Fungizidvariante (Fung) und den mit M. ochracea WG behandelten Varianten $1 \mathrm{~kg} / \mathrm{ha}$ Herbst (1 kgHe), $2 \mathrm{~kg} / \mathrm{ha}$ Herbst (2 kgHe), $1 \mathrm{~kg} / \mathrm{ha}$ HerbstFrühjahr (1 kgHe/Fr) und 2 kg/ha Herbst-Frühjahr (2 kgHe/Fr); n = 4; FisherTest (LSD) $\mathrm{p} \leq 0,05$.

Anders als bei der visuellen Bonitur wurde der stärkste Befall mit V. longisporum bei der Real-time PCR Untersuchung in der mit 2 kg/ha M. ochracea WG im Herbst behandelten Variante gemessen. Der geringste Gehalt an Verticillium-DNA wurde bei Rapsstängelproben der Herbst-, Frühjahrsbehandlung mit 2 kg/ha M. ochracea WG im 
Vergleich zu den übrigen Behandlungsvarianten ermittelt. Diese Unterschiede waren statistisch nicht abzusichern (Abb 38 links). Vergleicht man die beiden Untersuchungsmethoden, so konnte kein statistisch absicherbarer Zusammenhang $\left(\mathrm{R}^{2}=0,145\right)$ zwischen Mikrosklerotienbesatz und DNA-Gehalt von V. longisporum in der Trockenmasse festgestellt werden (Abb. 38 rechts).
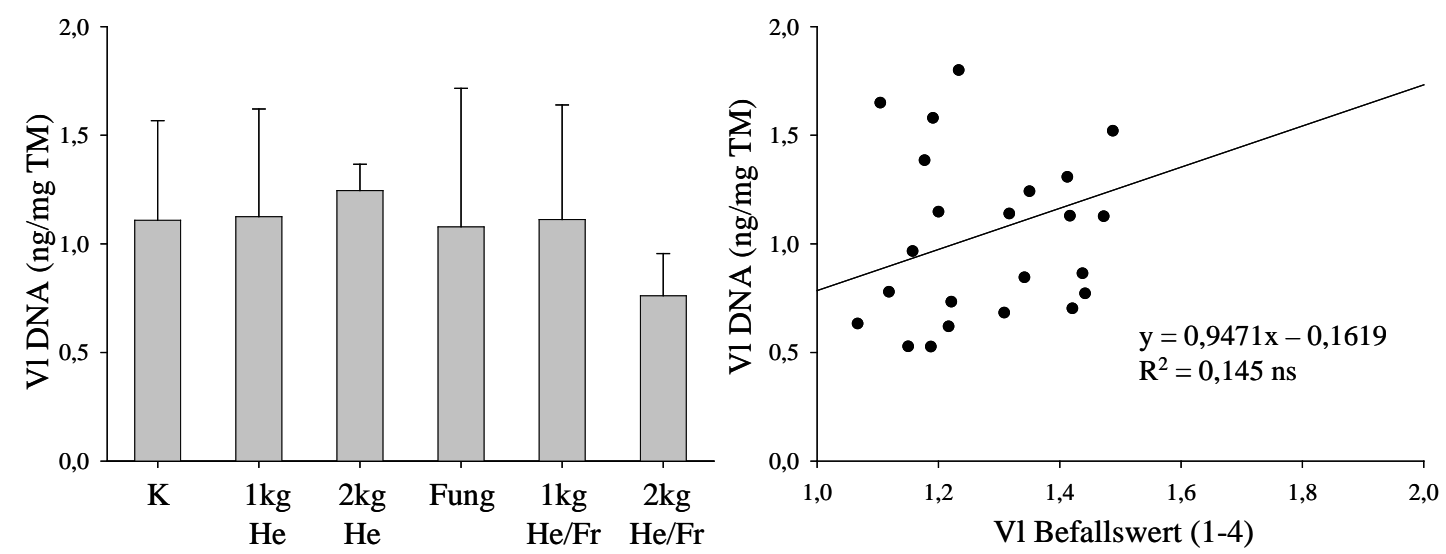

Abb. 38: DNA-Gehalt von $V$. longisporum in der Trockenmasse (ng/mg TM) von Winterraps (Sorte Trabant) im Winterrapsmonokulturversuch am Standort „Große Lage“ Göttingen-Weende im Versuchsjahr 2008/2009 (links) und Regressionsanalyse zwischen DNA-Gehalt (ng/mg TM) von V. longisporum und mittlerem Verticillium-Befallswert (1-4) (rechts). Dargestellt sind die unbehandelte Kontrolle (K), die Fungizidvariante (Fung) und die mit M. ochracea WG behandelten Varianten $1 \mathrm{~kg} / \mathrm{ha}$ Herbst (1 kgHe), $2 \mathrm{~kg} / \mathrm{ha}$ Herbst (2 kgHe), 1 kg/ha Herbst-Frühjahr (1 kgHe/Fr) und 2 kg/ha HerbstFrühjahr (2 kgHe/Fr); n = 4; Pearson Korrelationstest; ns. Nicht signifikant bei $\alpha=0,05$; Fisher-Test (LSD) $\mathrm{p} \leq 0,05$.

\subsubsection{Kornertrag}

Im Jahr 2008 konnte aufgrund von Hagelschlag keine Ertragserfassung durchgeführt werden.

Im Jahr 2009 wurde ein Durchschnittsertrag von 29 dt/ha geerntet. Es wurden keine signifikanten Ertragsunterschiede zwischen der Kontrolle, der Fungizidvariante und den mit M. ochracea WG behandelten Varianten gemessen (Daten nicht dargestellt).

\subsubsection{Einfluss von M. ochracea auf den Pathogenbefall in einer Winterraps-Winterweizen Fruchtfolge}

In diesem Fruchtfolgeversuch wurde ein möglicher Abbau des Inokulums von P. lingam und V. longisporum durch jährliche Behandlungen mit M. ochracea WG auf Winter- 
raps- und Winterweizen-Ernterückstände, und die Auswirkungen auf den Befall von Winterraps mit diesen Schadpathogenen im Jahr 2009 untersucht. Vor der Winterweizenaussaat im Herbst 2007 wurde eine Behandlung mit $1 \mathrm{~kg} / \mathrm{ha}$ und $2 \mathrm{~kg} / \mathrm{ha}$ M. ochracea WG auf die Winterraps-Ernterückstände durchgeführt. Im Herbst 2008 wurde vor der Winterrapsaussaat, und im Frühjahr 2009 in den Winterrapsbestand eine Behandlung mit 1 kg/ha und 2 kg/ha M. ochracea WG durchgeführt.

\subsubsection{Befall mit $P$. lingam}

Im Jahr 2009 kam es zu einem mittelstarken Befall des Wurzelhalses mit P. lingam und einem deutlich schwächeren Befall des Stängels.

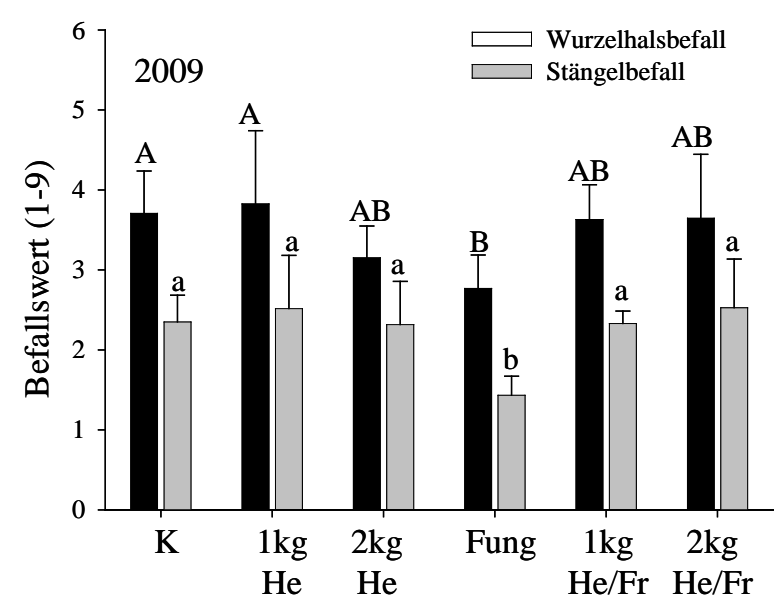

Abb. 39: Befall der Rapspflanzen mit $P$. lingam im Winterraps-Winterweizen Fruchtfolgeversuch am Standort „Große Lage“ Göttingen-Weende im Versuchsjahr 2008/2009. Dargestellt ist der mittlere Phoma-Befallswert (1-9) an Wurzelhals und Stängel an der Winterrapssorte Trabant in BBCH 80. Behandlungsvarianten: unbehandelten Kontrolle (K); Fungizidvariante (Fung); mit M. ochracea WG behandelte Varianten $1 \mathrm{~kg} / \mathrm{ha}$ Herbst (1 kgHe), $2 \mathrm{~kg} / \mathrm{ha}$ Herbst (2 kgHe), $1 \mathrm{~kg} / \mathrm{ha}$ Herbst-Frühjahr (1 kgHe/Fr) und $2 \mathrm{~kg} / \mathrm{ha}$ HerbstFrühjahr (2 kgHe/Fr); $n=4$; Fisher-Test (LSD) $\mathrm{p} \leq 0,05$.

Durch Behandlungen mit 2 kg/ha M. ochracea WG im Herbst 2007 und 2008 trat ein tendenziell geringerer Wurzelhalsbefall im Vergleich zur Kontrollvariante auf. Durch Behandlungen mit 1 kg/ha und 2 kg/ha M. ochracea WG im Herbst 2007 bzw. Herbst und Frühjahr 2008/2009 konnte keine Reduktion des Wurzelhalsbefalls mit P. lingam im Vergleich zur Kontrolle nachgewiesen werden. Behandlungen mit M. ochracea WG führten in keiner Behandlungsvariante zu einer Reduktion des Stängelbefalls mit P. lingam. Der geringste Wurzelhals- und Stängelbefall wurde in der Fungizidvariante bonitiert. Durch eine zweimalige Fungizidbehandlung im Jahr 2009 in BBCH 50 und 
BBCH 63 kam es zu einem signifikant geringeren Befall des Wurzelhalses mit

$P$. lingam im Vergleich zur Kontrolle und der mit 1 kg/ha M. ochracea WG im Herbst behandelten Variante. Im Vergleich zu den mit 2 kg/ha im Herbst und mit 1 kg/ha bzw. $2 \mathrm{~kg} / \mathrm{ha}$ im Herbst und im Frühjahr behandelten Varianten wurde nur eine tendenzielle Reduktion des Phoma-Wurzelhalsbefalls festgestellt. Der Befall des Stängels mit $P$. lingam konnte hingegen durch die zweimalige Fungizidbehandlung im Vergleich zu allen anderen Behandlungsvarianten signifikant reduziert werden (Abb. 39).

\subsubsection{Befall mit V. longisporum}

Bei der visuellen Befallsbonitur wurde nur ein schwacher Befall der Rapsstoppeln mit V. longisporum ermittelt. Der stärkste Verticillium-Befall wurde in der Fungizidvariante bonitiert. Behandlungen mit M. ochracea WG führten in keiner Behandlungsvariante zu einer Reduktion des Befalls der Rapspflanzen mit V. longisporum (Abb. 40).

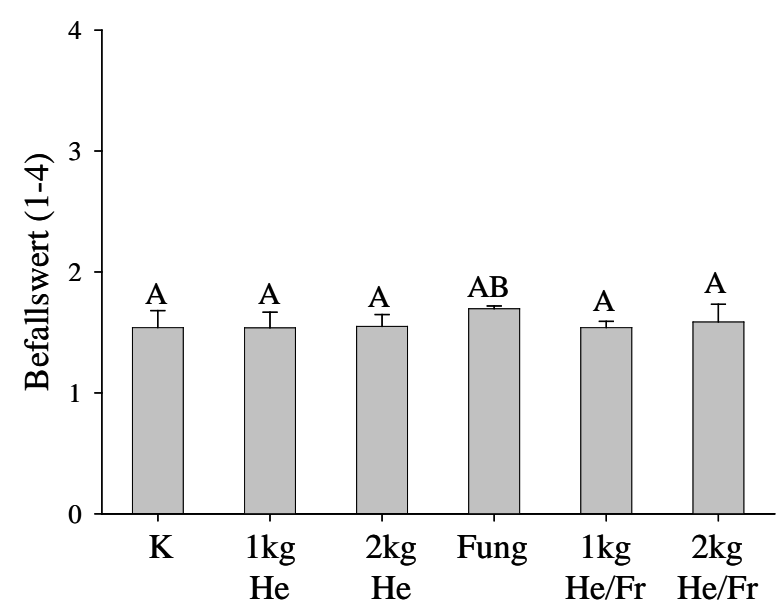

Abb. 40: Befall der Rapspflanzen mit V. longisporum im Winterraps-Winterweizen Fruchtfolgeversuch am Standort „Große Lage“ Göttingen-Weende im Versuchsjahr 2008/2009. Dargestellt ist der Mittlere V. longisporum Befallswert (1-4) an der Sorte Trabant in der unbehandelten Kontrolle (K), der Fungizidvariante (Fung) und den mit M. ochracea WG behandelten Varianten $1 \mathrm{~kg} /$ ha Herbst (1 kgHe), 2 kg/ha Herbst (2 kgHe), 1 kg/ha Herbst-Frühjahr (1 kgHe/Fr) und 2 kg/ha Herbst-Frühjahr (2 kgHe/Fr); $\mathrm{n}=4$; Fisher-Test (LSD) $\mathrm{p} \leq 0,05$.

\subsubsection{Auswirkungen auf den Kornertrag}

Im Sommer 2009 wurde im Winterraps-Winterweizen Fruchtfolgeversuch durchschnittlich bei allen Behandlungsvarianten ein Winterraps-Kornertrag von 38,2 dt/ha geerntet. 


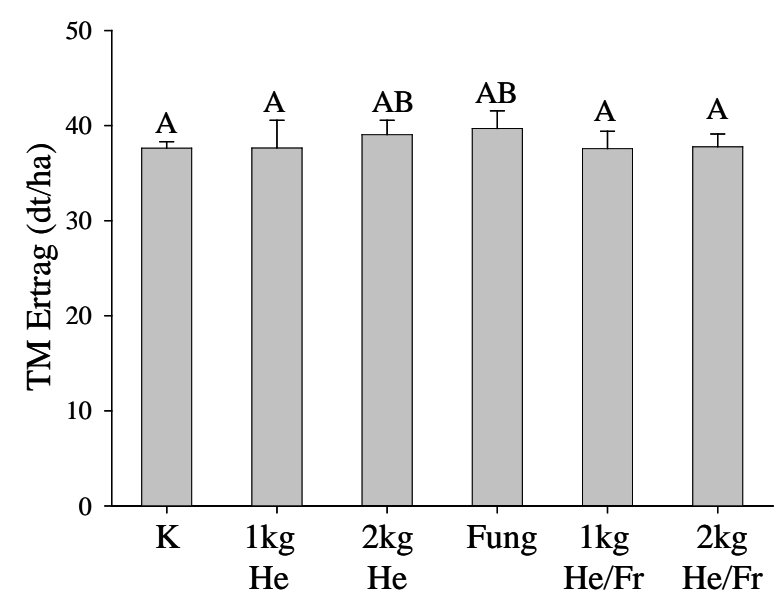

Abb. 41: Kornertrag von Winterraps im Winterraps-Winterweizen Fruchtfolgeversuch am Standort „Große Lage“ Göttingen-Weende im Versuchsjahr 2008/2009. Dargestellt ist der Trockenmassekornertrag der Sorte Trabant in der unbehandelten Kontrolle (K), der Fungizidvariante (Fung) und den mit M. ochracea WG behandelten Varianten $1 \mathrm{~kg} / \mathrm{ha}$ Herbst (1 kgHe), $2 \mathrm{~kg} / \mathrm{ha}$ Herbst (2 kgHe), 1 kg/ha Herbst-Frühjahr (1 kgHe/Fr) und 2 kg/ha HerbstFrühjahr (2 kgHe/Fr); $n=4$; Fisher-Test (LSD) $\mathrm{p} \leq 0,05$.

Die höchsten Kornerträge wurden in der im Herbst mit 2 kg/ha M. ochracea WG behandelten Variante (39 dt/ha) und der Fungizidvariante (39,7 dt/ha) geerntet. Es wurde ein Mehrertrag von 1,4 dt/ha und 2,1 dt/ha im Vergleich zur Kontrolle (37,6 dt/ha) geerntet. Bei den übrigen Behandlungsvarianten wurden keine Steigerungen des Kornertrages durch Behandlungen mit M. ochracea WG erzielt. Diese Unterschiede konnten statistisch nicht abgesichert werden (Abb. 41). 


\section{Diskussion}

In der vorliegenden Arbeit wurde das antagonistische Potential von Microsphaeropsis ochracea auf die Getreidepathogene Gibberella zeae (Fusarium graminearum) Mycosphaerella graminicola (Septoria tritici), Pyrenophora triticirepentis (Drechslera tritici-repentis) und die Rapspathogene Leptosphaeria maculans (Phoma lingam) und Verticillium longisporum untersucht. Die nachfolgende Diskussion behandelt eingangs die taxonomische Einordnung und anschließend die antagonistische Wirkung von M. ochracea. In den anschließenden Kapiteln wird auf das antagonistische Potential von M. ochracea auf $V$. longisporum und F.graminearum in vitro eingegangen. Zusätzlich wird der spezifische Nachweis von M. ochracea mittels Polymerase Ketten Reaktion (PCR) diskutiert. Abschließend steht die antagonistische Wirkung von M. ochracea auf die o.g. pilzlichen Pathogene in Feld- und Gewächshausversuchen, und das Wachstum von M. ochracea im Boden zur Diskussion.

\subsection{Taxonomische Einordnung von M. ochracea}

Mitte der 1990er Jahre wurde M. ochracea von Apfelblättern aus kanadischen Apfelplantagen isoliert und nach ersten Untersuchungen als Coniothyrium spp. identifiziert (Bernier et al., 1996). Durch licht- und elektronenmikroskopische Untersuchungen wurden die Isolate (speziell P130A) dann der Gattung Microsphaeropsis zugeordnet, wobei beide Gattungen morphologisch schwer zu unterscheiden sind. C. minitans und M. ochracea bilden Pyknidien mit einem Durchmesser von 70-150 $\mu \mathrm{m}$. Dabei sind die Konidien von $M$. ochracea mit einer Größe von 3,5-5,5 x 1-2 $\mu \mathrm{m}$ kleiner als die Konidien von C. minitans (6-7 x 3,5-6,5 $\mu \mathrm{m}$ ) (Carisse et al., 2002b; Grendene et al., 2002). Weitaus größere morphologische Ähnlichkeiten wurden zwischen den Konidien von M. ochracea und Microsphaeropsis arundinis festgestellt. Da beide Microsphaeropsis Arten ein unterschiedliches Wachstumsverhalten auf Nährmedien zeigten und im Gegensatz zu Marundinis die Pyknidien von M. ochracea kein Ostiolum ausbilden, wurde M. ochracea als separate Art gelistet (Carisse et al., 2002b).

Sowohl Microsphaeropsis spp. als auch Coniothyrium spp. gehören aufgrund der Pyknidienbildung zu den Coelomyceten. Angesichts der Ähnlichkeit der Isolate von Microsphaeropsis spp. mit Coniothyrium spp. wurden sie fälschlicherweise in vielen Untersuchungen der Gattung Coniothyrium spp. zugeordnet (Morgan-Jones \& White, 
1987; Sutton, 1980; Morgan-Jones 1974). C. minitans ist ein bedeutender Mykoparasit von Sklerotien verschiedener Sclerotinia-Arten (El-Syed \& Embaby, 2006). Bisher ist erst eine Microsphaeropsis-Art als möglicher Mykoparasit in der Literatur beschrieben. Watson \& Miltimore (1975) berichteten erstmalig die Mykoparasitierung der Sklerotien von Sclerotinia sclerotiorum durch Microsphaeropsis centaureae. Weitere Untersuchungen zum mykoparasitischen Potential dieser Pilzart sind nicht bekannt.

Aufgund der Tatsache des geringen Untersuchungsumfanges über $M$. ochracea und der hohen taxonomischen Ähnlichkeiten von M. ochracea zu C. minitans, werden nachfolgend die Forschungsergebnisse über C. minitans hauptsächlich als Grundlage für die Diskussion der Ergebnisse dieser Arbeit herangezogen. Dabei wird schwerpunktmäßig auf die erfolgreiche biologische Bekämpfung von Sclerotinia spp. durch C. minitans eingegangen.

\subsection{Antagonistische Wirkmechanismen von M. ochracea}

Die biologische Bekämpfung phytopathogener Pilze durch Antagonisten beruht auf verschiedenen Wirkmechanismen. Dabei ist für die Wirksamkeit von entscheidender Bedeutung, ob der betrachtete Organismus sein antagonistisches Potential in vitro, im Gewächshaus und/oder im Freiland etablieren kann. Die Produktion antibiotischer Verbindungen spielt bei der biologischen Bekämpfung phytopathogener Pilze durch Bakterien bzw. pilzliche Antagonisten eine wichtige Rolle (Fravel, 1988). Ein Beispiel hierfür stellt die Ausscheidung von Gliovirin durch Trichoderma virens dar, welches zur Bekämpfung von Pythium ultimum genutzt wird (Howel, 2003).

Bei in vitro-Untersuchungen wurde die Hemmung des radialen Myzelwachstums phytopathogener Pilze durch M. ochracea auf verschiedenen Nährmedien untersucht. Die Bildung von Hemmzonen zwischen dem betrachteten Pathogen und dem Antagonist gilt als ein Indiz für die Ausscheidung antibiotisch wirkender Verbindungen (Fokkema, 1973). Bei den langsam wachsenden Rapspathogenen (14dpi) V. longisporum und P. lingam wurde eine stärkere Hemmung (19-29\%) des radialen Myzelwachstums im Vergleich zu den schnell wachsenden Getreidepathogenen (9dpi) F. graminearum und D. tritici-repentis (6-16\%) gemessen. Bei keinem der untersuchten Pathogene wurde eine Bildung von Hemmzonen zwischen Pathogen und Antagonist beobachtet. Daraus lässt sich schließen, dass es zu keiner Bildung antibiotischer Verbindungen durch M. ochracea kam. Diese Beobachtung findet sich in den Untersuchungen zu 
potentiellen Antagonisten von Drechslera sorokiniana (Fokkema, 1973) wieder. Eine mögliche Erklärung der Hemmung könnte die von Alabouvette et al, (2006) und Whipps (2001) beschriebene Konkurrenz von Pathogen und Antagonist um Nährstoffe und Raum sein. Diese scheint bei dem durchgeführten in vitro-Test eine entscheidende Rolle gespielt zu haben. Ein Hinweis darauf war die stärkere Hemmung des radialen Myzelwachstums bei den langsam wachsenden Rapspathogenen, im Vergleich zu den schneller wachsenden Getreidepathogenen.

Ein weiterer bedeutender Wirkungsmechanismus von pilzlichen Antagonisten auf phytopathogene Pilze ist die Mykoparasitierung. Dabei stellen Trichoderma virens, als Mykoparasit von Rhizoctonia solani und C.minitans als Mykoparasit verschiedener Arten von Sclerotinia, die wahrscheinlich bedeutendsten Vertreter der Mykoparasiten dar (Whipps, 2001; Howel 2003). Die Konidien von C. minitans werden durch Ausscheidungen der Sklerotien von S. sclerotiorum zum Keimen stimuliert (Whipps \& Grewal, 1991). C. minitans ist anschließend in der Lage, durch Risse in der Sklerotienrinde und durch Ausübung von mechanischem Druck auf die Wände der Rindenzellen, die Sklerotien zu penetrieren. Unter Abgabe strukturlösender Enzyme (Cellulasen, Glucanasen) wird das Sklerotienmark zerstört und als Nährstoffquelle erschlossen. Dadurch werden die Sklerotien abgetötet und an ihrer Keimung gehindert (Phillips \& Price, 1983; Jones et al., 1973; Kaur et al., 2005). Ähnliche Prozesse wurden bei der Besiedlung der Zellen von $V$. inaequalis und $R$. solani durch $M$. ochracea beobachtet. M. ochracea wächst gerichtet zum Pathogenmyzel hin. Dabei penetriert es die Pathogenzellen durch Ausübung von mechanischem Druck unter Ausscheidung strukturlösender Enzyme und parasitiert diese (Benyagoub et al., 1998). Melanisierte Pilzstrukturen stellen dabei eine besondere Attraktivität für die Besiedlung durch M. ochracea dar (Bassam et al., 2002). Carisse et al. (2001) berichtet von der Exkretion antibiotisch wirkender Verbindungen durch M. ochracea. Diese schädigen die Zellen von $R$. solani und fungieren somit als ein wichtiger Bestandteil des antagonistischen Wirkmechanismus. Diese Beobachtung konnte bei den hier durchgeführten Untersuchungen nicht bestätigt werden. Vielmehr spielt die Konkurrenz um Nährstoffe und Raum eine entscheidende Rolle im antagonistischen Wirkmechanismus. 


\subsection{Interaktionsstudien zwischen Pathogenen und M. ochracea in vitro}

Der folgende Abschnitt beleuchtet das antagonistische Potential von M. ochracea gegenüber Mikrosklerotien von Verticillium spp. und Perithezien von G. zeae in vitro. Dabei werden vor allem Umweltfaktoren und Aufwandmengen von M. ochracea diskutiert. Diese können eine erfolgreiche Wirt-Parasit Interaktion in vitro, aber auch unter Gewächshaus- und Feldbedingungen, wesentlich beeinflussen. Darüber hinaus wird die antagonistische Wirkung von $M$. ochracea gegenüber $V$. longisporum auf Rapsstängeln als natürliche Nährstoffquelle betrachtet.

Zur Untersuchung des mykoparasitischen Potentials von M. ochracea auf Mikrosklerotien von Verticillium spp. und den Perithezien von G. zeae wurden standardisierte in vitro-Testverfahren entwickelt. Eine standardisierte Inokulumproduktion der Pilze ist hierbei von entscheidender Relevanz, um eine Reproduzierbarkeit der Ergebnisse zu gewährleisten. Unter Berücksichtigung dieser Rahmenbedingungen erwies sich der Filterplättchentest (vgl. 2.9.3) als eine geeignete Methode zur Untersuchung verschiedener Umweltfaktoren, die die Wirt-Mykoparasit Interaktionen wesentlich beeinflussen. Frühere Untersuchungen haben gezeigt, dass sich ähnelnde Umweltansprüche von Pathogen und Antagonist für eine erfolgreiche biologische Bekämpfung phytopathogener Pilze in vitro und unter Gewächshaus- und Feldbedingungen von entscheidender Bedeutung sind (Larkin \& Fravel, 2002; Fravel, 2005). Einen wesentlichen Einfluss auf den Bekämpfungserfolg phytopathogener Pilze durch pilzliche Antagonisten haben dabei die Temperatur, der pH-Wert, die Feuchtigkeit und der Lichtanspruch von Pathogen und Antagonist (Kredics et al., 2003; Larkin \& Fravel, 2002; Whipps \& Gerlagh, 1992).

Auf Grundlage dieser Kenntnisse wurde die Wirkung von M. ochracea über ein weites Temperaturspektrum untersucht. Es kam bereits 6 Tage nach der Behandlung von Mikrosklerotien von $V$. longisporum mit M. ochracea und Inkubation bei geringen Temperaturen $\left(4^{\circ} \mathrm{C}\right)$ zu einer Hemmung der Mikrosklerotienkeimung. Mit Erhöhung der Inkubationstemperaturen wurde das mykoparasitische Potential von M. ochracea signifikant gesteigert, wobei M. ochracea sein volles mykoparasitisches Potential bei Temperaturen über $16^{\circ} \mathrm{C}$ entfaltete. Carisse \& Bernier (2002a) wiesen in ihren Untersuchungen nach, dass es erst ab Inkubationstemperaturen von $10^{\circ} \mathrm{C}$ zur Sporenkeimung und Pyknidienbildung von M. ochracea kommt. Dabei wurden die Untersuchungen von Carisse \& Bernier (2002a) zur Sporenkeimung über $24 \mathrm{~h}$ auf 
Nährmedium durchgeführt. Im Gegensatz dazu fanden die hier dargestellten Untersuchungen über einen Zeitraum von 6 bzw. 10 Tagen statt. Zu ähnlichen Ergebnissen wie Carisse \& Bernier (2002a) kamen auch McQuilken et al. (1997) in ihren Studien zu C. minitans. Dabei wurde bei Inkubationstemperaturen kleiner $10^{\circ} \mathrm{C}$ keine Sporenkeimung von C. minitans auf Nährmedium beobachtet. Anderen Berichten zufolge waren bei Inkubationstemperaturen von $4^{\circ} \mathrm{C}$, 7 dpi $30 \%$ der Sporen von C. minitans gekeimt und $100 \%$ der Sklerotien von S. sclerotiorum durch C. minitans parasitiert (Trutmann et al., 1980). Darüber hinaus kann die Sporenkeimung der Antagonisten durch die Zielorgane (Mikrosklerotien, Sklerotien) induziert werden. Es wurde in früheren Untersuchungen nachgewiesen, dass das Wachstum bzw. die Sporenkeimung von M. ochracea und C. minitans in Anwesenheit von Zielpathogenen begünstigt wird (Bassam et al., 2002; Benyagoub et al., 1998; Whipps \& Grewal, 1991). Ein weiterer wichtiger Umweltfaktor der den Bekämpfungserfolg bei der biologischen Bekämpfung pilzlicher Schadorganismen durch Antagonisten beeinflusst, ist der $\mathrm{pH}$ Wert (Kredics et al., 2003; Adams, 1990). Deshalb wurde der Einfluss des pH-Wertes auf das mykoparasitische Potential von M. ochracea untersucht. Es konnte eine steigende Mortalität der Mikrosklerotien mit ansteigendem pH-Wert festgestellt werden. Ein direkter Einfluss des pH-Wertes auf die Keimung von Mikrosklerotien konnte ausgeschlossen werden, da es in der Wasserkontrolle bei allen pH-Stufen zu einer Keimung der Mikrosklerotien von über 95\% kam. Dies widerspricht den Beobachtungen von Carisse \& Bernier (2002a). Diesen Untersuchungen zur Folge keimen Sporen des Isolates P130A von M. ochracea zwischen $\mathrm{pH} 4$ und $\mathrm{pH}$ 6, wohingegen bei anderen Isolaten von M. ochracea eine Sporenkeimung über einen weiteren pH-Bereich beobachtet wurde. Dabei muss berücksichtigt werden, dass die Untersuchungen der pH-Wert abhängigen Sporenkeimung von M. ochracea, ähnlich der temperaturabhängigen Sporenkeimung von Carisse \& Bernier (2002a), nach 16 bzw. $32 \mathrm{~h}$ Inkubationsdauer ausschließlich auf Nährmedium durchgeführt wurden. Im Gegensatz dazu fand die hier dargestellte Studie über einen Zeitraum von 10 Tagen statt. In früheren Untersuchungen wurde ermittelt, dass der $\mathrm{pH}$-Wert einen entscheidenden Einfluss auf die Sporenkeimung von C.minitans hat. Sporen von C. minitans keimen bei pH-Werten von 3-8,5, wobei die stärkste Sporenkeimung bei pH-Werten von 4,5-7 stattfindet (McQilken et al., 1997). Zusätzlich scheinen niedrigere 
pH-Werte die Mykoparasitierung der Sklerotien von S. sclerotiorum durch C. minitans zu begünstigen (Yang et al., 2009).

Licht kann einen wesentlichen Einfluss auf die Reproduktion und die Wirkung pilzlicher Antagonisten haben. Daher wurde in weiteren Versuchsansätzen der Einfluss von Licht auf die Reproduktion von M. ochracea auf Nährmedien und sterilem Rapsstroh untersucht. Des Weiteren wurde der Einfluss von Licht auf die Parasitierung der Mikrosklerotien von $V$. longisporum durch $M$. ochracea untersucht.

Es konnte beobachtet werden, dass es auf Rapsstroh und Nährmedium zu einer stärkeren Pyknidienbildung bei Belichtung im Vergleich zum Lichtausschluss kam. Der Lichtausschluss bewirkte sowohl auf Rapsstängeln als auch Nährmedium ein stärkeres Myzelwachstum von M. ochracea im Vergleich mit den belichteten Varianten. Entsprechende Ergebnisse werden von Carisse \& Bernier (2002a) beschrieben. Sie stellten dar, dass es unter Lichtausschluss weder auf Apfelblättern, noch auf Nährmedium zu einer Pyknidienbildung durch M. ochracea (Isolat P130A) kam. Dabei berichten sie von einer höheren Pyknidiendichte mit ansteigender Belichtungsdauer, wobei dies stark von dem verwendeten $M$. ochracea-Isolat abhängig ist.

Anschließend wurde das mykoparasitische Potential von M. ochracea auf Mikrosklerotien von V. longisporum in Abhängigkeit von der Belichtung untersucht. Dabei wurde kein Einfluss von Licht auf die antagonistische Wirkung von M. ochracea auf die Mikrosklerotien von $V$. longisporum festgestellt.

Ähnliche Ergebnisse sind in der Literatur bei Untersuchungen über C. minitans beschrieben worden. Hierbei zeigte Licht keinen Einfluss auf die Sporenkeimung von C. minitans. Jedoch kommt es unter Lichteinfluss zu einer deutlich stärkeren Pyknidienbildung. Ähnlich zu M. ochracea ist dieses stark vom Pilzisolat abhängig (McQuilken et al., 1997; Grendene et al., 2002). Darüber hinaus ist C. minitans in der Lage, Sklerotien von S. sclerotiorum unter Lichtausschluss sowohl unter kontrollierten Bedingungen als auch im Boden zu parasitieren (Benett et al., 2006; McQuilken et al., 1995).

Somit scheint Licht kein limitierender Faktor für eine erfolgreiche biologische Bekämpfung der Mikrosklerotien von V. longisporum durch $M$. ochracea zu sein.

Neben den bereits aufgeführten Umweltfaktoren spielen die Aufwandmenge, der Applikationszeitpunkt, und die Applikationshäufigkeit von Antagonisten eine wichtige Rolle für den biologischen Bekämpfungserfolg von pilzlichen Schadorganismen 
(Carisse \& Rolland, 2004; Freeman et al., 2004). In den durchgeführten Versuchen wurden Mikrosklerotien von V. longisporum bei einer Sporendichte von $1 \times 10^{4}$ Sporen/ml durch $M$. ochracea bereits 6 dpi erfolgreich in ihrer Keimung gehemmt. Dabei wurde durch Verlängerung der Inkubationszeit und Erhöhung der Aufwandmenge der Wirkungsgrad von M. ochracea signifikant gesteigert. Bisher existieren keine vergleichbaren Untersuchungen über den Zusammenhang zwischen Sporendichte von M. ochracea und der Mykoparasitierung phytopathogener Pilze. Turner \& Tribe (1976) weisen in ihren Untersuchungen zu C. minitans einen eindeutigen Zusammenhang zwischen der Sporendichte und der Parasitierung der Sklerotien von S. sclerotiorum nach. So steigt der Parasitierungserfolg von Sklerotien durch $C$. minitans mit steigender Sporendichte an. Des Weiteren nimmt der Anteil parasitierter Sklerotien mit Verlängerung der Inkubationszeit deutlich zu.

Aus in vitro-Untersuchungen können keine Rückschlüsse auf benötigte Aufwandmengen von $M$. ochracea unter Feldbedingungen gezogen werden. Doch konnte gezeigt werden, dass ein deutlicher Zusammenhang zwischen Aufwandmenge von M. ochracea, der Inkubationsdauer und dem Bekämpfungserfolg besteht.

Der biologische Bekämpfungserfolg wird nicht nur von Umweltfaktoren, der Aufwandmenge und der Biologie des Antagonisten beeinflusst. So spielen auch biologische und morphologische Eigenschaften der Zielpathogene eine wesentliche Rolle beim biologischen Bekämpfungserfolg.

Verschiedene Studien haben das mykoparasitische Potential verschiedener Isolate von C. minitans und M. ochracea näher beleuchtet. Hierbei wurde festgestellt, dass Unterschiede beim biologischen Bekämpfungserfolg phytopathogener Pilze in Abhängigkeit vom verwendeten Isolat vorherrschen (Carisse \& Bernier, 2002a; Jones \& Stewart, 2000). Darüber hinaus wurde nachgewiesen, dass Sklerotien von verschiedenen Sclerotinia spp. unterschiedlich stark von C. minitans parasitiert werden (Turner \& Tribe, 1976; El-Syed \& Embaby, 2006).

Deshalb wurde das mykoparasitische Potential von M. ochracea auf Mikrosklerotien von V. longisporum im Vergleich zu Mikrosklerotien von V. dahliae untersucht. Dabei stellte sich über den gesamten Untersuchungszeitraum eine signifikant höhere Mortalität der mit M. ochracea inokulierten Mikrosklerotien von $V$. longisporum im Gegensatz zu Mikrosklerotien von V. dahliae heraus (vgl. 3.1.3.5). Dies zeigt, dass Mikrosklerotien 
von $V$. longisporum leichter als Mikrosklerotien von V.dahliae durch M. ochracea parasitiert werden.

In weiteren Untersuchungen wurde festgestellt, dass Mikrosklerotien von V. dahliae ein deutlich schnelleres Keimverhalten über einen weiten Temperaturbereich im Vergleich zu Mikrosklerotien von $V$. longisporum zeigen. Weiterhin wurde bei $V$. dahliae eine schnellere Neubildung von Mikrosklerotien über einen breiten Temperaturbereich verglichen mit $V$. longisporum bonitiert (vgl. 3.1.2; Tab. 9 Anhang).

Daraus kann geschlussfolgert werden, dass Mikrosklerotien von V.dahliae durch M. ochracea zwar parasitiert werden, sich aber aufgrund der schnelleren Keimung und des schnelleren Wachstums besser gegenüber M. ochracea durchsetzen können, als Mikrosklerotien von V. longisporum. Alabouvette et al, (2006) und Whipps (2001) schreiben in ihren Studien, dass schnell wachsende Pathogene aufgrund ihres leistungsfähigeren Nährstoffaneignungsvermögens in der Lage sind, sich besser gegenüber Antagonisten $\mathrm{zu}$ behaupten. Somit hat das Nährstoffaneignungsvermögen von Antagonist und Pathogen einen entscheidenden Einfluss auf das antagonistische Potential.

Bisher sind keine Untersuchungen bekannt bei denen die Mikrosklerotienkeimung von $V$. longisporum und $V$. dahliae in Abhängigkeit von der Temperatur untersucht wurde. Es liegen aber Studien vor bei denen verschiedene Isolate von V. dahliae deutliche Unterschiede bei der Mikrosklerotienbildung in Abhängigkeit von der Temperatur aufweisen (Soesanto \& Termoshuizen, 2001). Um genauere Aussagen über das Keimverhalten der Mikrosklerotien von $V$. longisporum und $V$. dahliae in Abhängigkeit von der Temperatur treffen zu können, müssten Erhebungen mit verschiedenen Isolaten von $V$. longisporum und $V$. dahliae durchgeführt werden.

Nach ersten Untersuchungen wurde ein hohes mykoparasitisches Potential von M. ochracea auf Mikrosklerotien von Verticillium spp. nachgewiesen. Daraufhin wurde das antagonistische Potential von M. ochracea gegenüber V. longisporum auf Rapsstängeln, der natürlichen Nährstoffquelle von V. longisporum, untersucht. Hierfür wurden sterile Rapsstängel mit V. longisporum und M. ochracea koinokuliert. Zusätzlich wurden Rapsstängel, die mit Mikrosklerotien von V. longisporum durchwachsen waren, mit $M$. ochracea inokuliert. 
Nach Inokulation steriler Rapsstängel mit V. longisporum bzw. V. longisporum und M. ochracea, wurde bei den mit V. longisporum inokulierten Rapsstängeln eine starke Mikrosklerotienbildung beobachtet. Bei den koinokulierten Varianten kam es nur zu einer vereinzelten Mikrosklerotienbildung und es wurde eine Pyknidienbildung von M. ochracea beobachtet. Bei den koinokulierten Rapsstängeln konnte ein signifikant geringerer DNA-Gehalt von $V$. longisporum und eine signifikant niedrigere Sporendichte von $V$. longisporum im Vergleich zu den mit $V$. longisporum inokulierten Rapsstängeln ermittelt werden (vgl. 3.1.4.1).

Anschließend wurden Rapsstängel, die mit Mikrosklerotien von V. longisporum bewachsen waren, mit M. ochracea bzw. Wasser inokuliert. Mittels Real-time PCR wurde in den mit M. ochracea inokulierten Variante nur ein leicht verringerter DNAGehalt von V. longisporum im Vergleich zu den Wasserkontrollen gemessen. Im Gegensatz dazu kam es in zwei von drei Behandlungsvarianten (10-40\% und 70-100\% Mikrosklerotiendeckungsgrad) zu einer signifikant geringeren Sporenproduktion durch $V$. longisporum in den mit M. ochracea behandelten Varianten, verglichen mit den jeweiligen Wasserkontrollen (vgl. 3.1.4.2).

Ähnliche Untersuchungen wurden von Bujold et al., (2001) mit G. zeae auf Weizenund Maisstroh durchgeführt. Dabei kam es zu einer signifikant geringeren Askosporenproduktion von G. zeae auf Weizen- bzw. Maisstroh, wenn M. ochracea zwei Wochen vor bzw. gleichzeitig mit G. zeae inokuliert wurde. Fand die Applikation von M. ochracea nach der Inokulation mit G. zeae statt, wurde die Askosporenproduktion durch G. zeae nur geringfügig reduziert.

Ein Grund für die geringere Produktion von Pathogeninokulum auf Raps- Weizen- und Maisstroh bei vorausgegangener bzw. gleichzeitiger Inokulation mit M. ochracea, ist die bessere Erschließung von Raum und die bessere Aneignung von Nährstoffen durch M. ochracea. Die Konkurrenz um Nährstoffe spielt dabei in vielen antagonistischen Systemen eine entscheidende Rolle (Whipps, 2001; Poppe et al., 2003).

Es wurde festgestellt, dass nach Inokulation von mikrosklerotienbewachsenen Rapsstängeln mit $M$. ochracea eine signifikant geringere Sporenproduktion durch V. longisporum stattfand. Im Vergleich zu den Wasserkontrollen wurden aber nur leicht geringere DNA-Gehalte ermittelt. Diese Diskrepanz könnte folgende Gründe haben: So werden Mikrosklerotien von $V$. longisporum ähnlich wie Zellen von $V$. inaequalis und 
$R$. solani durch M. ochracea parasitiert (Carisse et al., 2001; Benyagoub et al., 1998) Das bedeutet, sie werden in ihrer Fähigkeit zu keimen und an der Sporenproduktion gehindert. Bei der anschließenden Quantifizierung der DNA von V. longisporum wurde DNA von vitalen und abgetöteten Mikrosklerotien erfasst. Dies erklärt die geringen Unterschiede zwischen den Behandlungsvarianten mit M. ochracea und der Wasserkontrolle. Die Tatsache, dass bei PCR-Untersuchungen DNA aus lebenden und toten Zellverbänden nicht differenziert wird, stellt bei der Verwendung der PCRUntersuchung bei Antagonist-Pathogen Interaktionsstudien ein großes Problem dar. Somit können durch PCR-Verfahren keine eindeutigen Rückschlüsse auf die Vitalität von Organismen bzw. den Bekämpfungserfolg durch einen Antagonisten gezogen werden (Schaad \& Frederick, 2002; Henson et al., 1993).

In keinem der Versuchsjahre kam es bei den Feldversuchen mit Winterweizen Monokulturanbau zu einem Ährenbefall mit Fusarium. Deshalb wurde die antagonistische Wirkung von M. ochracea auf Myzel und Perithezien von F.graminearum in vitro untersucht. Nach Behandlung von mit Myzel bewachsenen Haferkörnern mit M. ochracea wurde in allen Behandlungsvarianten eine Perithezienbildung beobachtet. Nach 15 und 30 Tagen konnte eine tendenziell bzw. signifikant geringere Askosporenproduktion im Vergleich zur Wasserkontrolle ermittelt werden.

Nach Behandlung perithezienbewachsener Haferkörner mit M. ochracea wurde eine geringere Produktion von Askosporen beobachtet. Dabei konnte die Askosporenproduktion von F.graminearum durch Behandlung mit hohen Aufwandmengen von M. ochracea $\left(1 \times 10^{6}\right.$ Sporen $\left./ \mathrm{ml}\right)$ signifikant reduziert werden. Bei geringen Aufwandmengen $\left(1 \times 10^{4}\right.$ Sporen/ml) wurde demgegenüber nur eine schwache bzw. keine Reduktion der Askosporenproduktion ermittelt. Dies zeigt, ähnlich zu den Interaktionsstudien zwischen $V$. longisporum und $M$. ochracean, dass die Inokulumdichte von M. ochracea einen entscheidenden Einfluss auf den mykoparasitischen Wirkungsgrad hat. Ähnliche Untersuchungen wurden von Bujold et al., (2001) durchgeführt. Sie konnten in vitro eine reduzierte Askosporenproduktion nach Behandlungen mit M. ochracea nachweisen. Darüber hinaus konnten sie unter Feldbedingungen zeigen, dass Behandlungen mit M. ochracea die Perithezienreifung in manchen Jahren verzögerte. Im Gegensatz dazu konnte nicht sicher festgestellt werden, dass die Perithezienbildung auf Ernterückständen aufgrund einer Behandlung mit M. ochracea reduziert wurde. 
Betrachtet man die hier dargestellten Untersuchungen zusammen mit den Ergebnissen von Bujold et al., (2001), so ist M. ochracea in der Lage, das Fusariuminokulum in vitro zu reduzieren. Zur Verringerung des Inokulums von F. graminearum (G. zeae) unter Feldbedingungen scheint die antagonistische Wirkung von $M$. ochracea hingegen nicht auszureichen.

Es gibt eine Reihe von Bakterienstämmen, die unter Feldbedingungen ein hohes Potential zur Reduktion des Fusarium-Befalls zeigen. Demgegenüber gibt es bisher keine pilzlichen Antagonisten, die bei Feldapplikationen in der Lage sind, das Fusariuminokulum zu reduzieren (Gilbert \& Fernando, 2004).

\subsection{Polymerase Kettenreaktion zum Nachweis von $M$. ochracea}

Auf der Methode der Polymerase Kettenreaktion (polymerase chain reaction, PCR) basierende Untersuchungsverfahren werden seit vielen Jahren vermehrt in der pflanzenpathologischen Forschung und Diagnostik eingesetzt. Diese Technik bietet ein sensitives Verfahren, welches Organismen unabhängig von den Kulturbedingungen anhand ihrer genetischen Mekmale nachweisen kann. Dabei werden PCR basierte Verfahren zur Untersuchung der genetischen Diversität, Aufklärung von Pathogenitätsmechanismen und bei Wirt-Parasit Interaktionsstudien eingesetzt (Goldstein et al., 2000; Muthumeenakshi, 2007; Robb et al., 1993).

Werden PCR-Verfahren zum Nachweis pilzlicher Strukturen außerhalb von kontrollierten Systemen angewendet, so ist die Spezifität der PCR-Methodik für den zu untersuchenden Organismus von entscheidender Bedeutung. Hierbei hängt die Spezifität in erste Linie von den verwendeten Primerpaaren ab. Zeigen diese Oligonukleotide Kreuzreaktionen $\mathrm{zu}$ anderen Organismen ist eine Spezifität des Nachweises nicht gegeben. Darüber hinaus können die Spezifität und die Sensitivität der Untersuchungsmethode durch Veränderung der Annealing-Temperatur und der $\mathrm{MgCl}_{2}$-Konzentration optimiert werden (Schaad \& Frederick, 2002; Roux, 1995).

Die Primerentwicklung auf Basis von rDNA-Sequenzen der „Internal Transcribed Spacer“ (ITS) Region zum spezifischen Nachweis von Askomyzeten mittels PCRVerfahren ist eine weit verbreitete Methode. Dieser rDNA-Abschnitt zeigt starke Polymorphismen zwischen den verschiedenen Arten und bietet sich somit für die Entwicklung Art-spezifischer Primer an. Des Weiteren stehen in Datenbanken die 
sequenzierten ITS-Regionen vieler verschiedener Pilzarten zur Verfügung, wodurch diese Sequenzen zur Überprüfung der Spezifität von Primerpaaren genutzt werden können (Larena et al., 1999; Tooley et al., 1997).

Im Rahmen dieser Arbeit wurde die ITS-Region von M. ochracea mit dem Primerpaar ITS 4 und ITS 5 von White et al (1991) amplifiziert und darauffolgend sequenziert. Basierend auf der sequenzierten ITS-Region von M. ochracea und dem Abgleich von ITS-Regionen im Boden vorkommender phytopathogener Pilze wurden Primer für den Nachweis von M. ochracea abgeleitet. Dabei zeigte das anfangs erstellte Primerpaar deutliche Kreuzreaktionen zu C. minitans, beim Vergleich mit ITS-Sequenzen in Datenbanken, und eigenen Untersuchungen (Tab. 7 Anhang; Abb. 2 Anhang). Dies kann als Indiz für ein enges Verwandtschaftsverhältnis dieser beiden Arten herangezogen werden. Daraus kann abgeleitet werden, dass $M$. ochracea und C. minitans nicht nur morphologisch schwer zu unterscheiden und taxonomisch schwer einzuordnen sind (Morgan-Jones, 1974; Morgen-Jones \& White, 1987), sondern auch genetisch, basierend auf dem Abgleich der ITS-Regionen, deutliche Homologien aufweisen. Dabei bedeuten Homologien der ITS-Region nicht unbedingt, dass die phytopathogenen Pilze zur gleichen Art bzw. Unterart gehören (Schilling et al., 1996). In einem weiteren Ansatz wurden die für M. ochracea spezifischen Primer M.o 3.1 und M.o 4.1.1 entwickelt. Bei der Überprüfung des Primerpaares wurden keine positiven Reaktionen mit DNA von C. minitans und ausgewählten bedeutenden phytopathogenen Pilzen an Getreide und Raps festgestellt. Es traten auch keine Kreuzreaktionen mit DNA aus Pflanzengewebe von Raps, Weizen und mit DNA aus verschiedenen Ackerböden auf. Dabei muss festgehalten werden, dass es sich bei Boden um ein System mit einer hohen Diversität an Mikroorganismen handelt (Rondon et al., 1999). Aufgrund dieser Problematik ist es schwierig, spezifische Primer zu entwickeln, bei denen Kreuzreaktionen mit nicht kultivierbaren Bodenorganismen mit hoher Gewissheit ausgeschlossen werden können. Dabei ist es möglich, die Kreuzreaktivität eines Primerpaares zu prüfen, indem sie mit DNA-Proben aus verschiedenen Böden getestet wird. (Atkins et al., 2004; Faggian et al., 1999). Da für M.o 3.1 und M.o 4.1.1 keine Kreuzreaktivität mit Boden-DNA festgestellt wurde, kann davon ausgegangen werden, dass mit diesem Primerpaar M. ochracea sehr spezifisch nicht nur in vitro, und unter Gewächshausbedingungen, sondern auch unter Feldbedingungen nachgewiesen werden kann. Überdies hinaus konnte durch Anpassung der Annealing-Temperatur und der $\mathrm{MgCl}_{2}$ 
Konzentration M. ochracea bis zu einem Gehalt von 10 pg M. ochracea-DNA pro Reaktion nachgewiesen werden.

Wichtige Faktoren, welche die PCR-Reaktionen hemmen bzw. negativ beeinflussen können, werden als PCR-Inhibitoren bezeichnet. Dabei sind Huminsäuren, Phenole, Polysaccharide und Proteine die bedeutendsten Störstoffe, die während der DNAExtraktion aus Boden- und Pflanzenmaterial nicht vollständig entfernt werden können und somit die anschließenden PCR-Reaktionen negativ beeinflussen können (Wilson 1997; Monteiro et al., 1997; Demeke \& Adams 1992). So führen Proteasen zu einer aktiven Zersetzung der Taq-Polymerase, wodurch diese inaktiviert wird. Ähnlich dazu binden Phenole und Huminsäuren an die Taq-Polymerase. Huminsäuren bilden stabile Chelat-Komplexe mit Mg-Ionen, wodurch diese von der Taq-Polymerase nicht mehr als Kofaktoren genutzt werden können. Beides führt zu einer verminderten Aktivität bzw. zur Inaktivierung der Taq-Polymerase. Darüber hinaus können Proteine und Polysaccharide stabile Komplexe mit DNA bilden, wodurch diese für die Polymerase nicht mehr zugänglich ist (Kreader, 1996; Tsai \& Olson 1992; Sharma et al., 2002).

Die DNA-Extraktion aus Rapsstängeln, die für Interaktionsstudien zwischen M. ochracea und V. longisporum im Boden inkubiert wurden, erfolgte mittels CTABExtraktionsmethode nach Brandfaß \& Karlovsky (2006). Anschließend wurde die DNA mittels Sperminfällung aufgereinigt. Mit der Sperminfällung steht ein geeignetes Verfahren zur Verfügung, um aus DNA-Extrakten Inhibitoren zu beseitigen, die die PCRReaktionen negativ beeinflussen bzw. hemmen können (Hoppes \& Mc Clure, 1981; Kieser, 1984; Smalla et al., 1993). Trotz Sperminfällung und Verdünnung der DNAExtrakte kam es bei vielen Proben zu einer Hemmung der PCR-Reaktion. Dies lässt darauf schließen, dass durch die Sperminfällung die DNA-Extrakte nicht vollständig von PCR-Inhibitoren befreit werden konnten. Um die PCR-Untersuchung als sensitive Methode zum Nachweis von Organismen im Boden nutzen zu können, müssen effizientere DNA-Aufreinigungsschritte durchgeführt werden. Kresk \& Wellington (1999) untersuchten unterschiedliche DNA-Aufreinigungsverfahren für DNA aus Bodenproben. Sie fanden heraus, dass durch Anpassung des Extraktionsprotokolls der Reinheitsgrad der DNA erhöht werden kann. Durch Aufreinigung der DNA mit Crombach-Puffer in Verbindung mit SDS und Lysozym können deutlich höhere DNAReinheitsgrade im Vergleich zur Sperminfällung erreicht werden. Darüber hinaus kann durch genetische Veränderung der Taq-Polymerase der negative Einfluss von PCR- 
Inhibitoren auf die Taq-Polymerase vermindert werden. Durch die Verwendung von Klentaq-Polymerasen konnte die hemmende Wirkung von Inhibitoren auf PCRReaktionen im Vergleich zu Wildtyp Taq-Polymerasen deutlich gesenkt werden (Kermekchiev et al., 2009).

Eine weitere Möglichkeit, PCR-Inhibitoren beim Nachweis von Organismen im Boden mittels PCR-Untersuchung auszuschließen, ist die Durchführung von Bio-PCRs. Für diesen bisher vor allem bei Bakterien angewendeten Nachweis wird Bodensubstrat auf Fest- bzw. Flüssigmedium kultiviert. Die auswachsenden Organismen werden mittels PCR untersucht (Schaad \& Frederick, 2002; Schaad et al., 2007). Darüber hinaus wird bei dieser Untersuchungsmethode ausschließlich die DNA lebender Organismen erfasst und es kommt somit zu keinen falsch positiven Detektionen aufgrund eines Nachweises von DNA toter Zellen (Schaad, 1999).

\subsection{Gewächshausversuche mit V. longisporum und M. ochracea}

In Anlehnung an die Interaktionsstudien zwischen $V$. longisporum und M. ochracea unter kontrollierten Bedingungen, wurden Gewächshausversuche mit unsterilem Boden angelegt. Diese sollen im folgenden Kapitel näher beleuchtet und diskutiert werden.

In unsterilem Bodensubstrat wurde die Wirkung von M. ochracea auf die Mikrosklerotien von $V$. longisporum und die Auswirkung auf den Befall von Rapspflanzen mit V. longisporum untersucht. Aufgrund der kontrollierten Umwelteinflüsse im Gewächshaus sind gute Rahmenbedingungen gegeben, um die Wirkung von Antagonisten auf pilzliche Schadpathogene in unsterilem Boden zu prüfen (El-Sayed \& Embaby, 2006, Jones \& Whipps, 2002; Müller et al., 2004). Als Bodensubstrat wurde ein humus- und nährstoffarmes Lößlehm-Vermiculit Gemisch im Verhältnis 3:1 verwendet. Ziel war es, fungistatische Effekte möglichst auszuschließen, aber dennoch in einem unsterilen Bodensubstrat $\mathrm{zu}$ arbeiten. Dabei kann die Bodenfungistasis sowohl abiotischen (Mykostasis) als auch biotischen Ursprungs sein, wobei der biotisch bedingten Bodendfungistasis eine deutlich größere Bedeutung zukommt (Watson \& Ford, 1972; Dobbs \& Gash, 1965).

In zahlreichen Studien wurde ein ausgeprägter Zusammenhang zwischen der Höhe des Bodeninokulums von Verticillium spp. und dem Befall der Pflanzen mit Verticillium nachgewiesen (Ashworth et al., 1979; Pullman \& DeVay, 1982). Dabei sind die 
Pflanzenlänge und der Pflanzentrockenmasseertrag geeignete Parameter zur Erfassung des Verticillium-Befalls (Bhat \& Subbarao, 1999). Bei einem Inokulationsstufenversuch mit Mikrosklerotien wurde getestet, ob die o.g. Parameter geeignet sind, um die Inokulumdichte von V. longisporum im Boden zu überprüfen. Hierfür wurden $150 \mathrm{~g}$ Lößlehm-Vermiculit Gemisch mit 0, 20, 50, 100 und 200 mg Mikrosklerotien beimpft und „rapid cycling rapeseed“ (RCR) als Modellpflanze ausgesät. Bei diesem Inokulationssystem wurde ein deutlicher Zusammenhang zwischen Mikrosklerotiendichte im Boden und dem Rapspflanzenbefall mit V. longisporum nachgewiesen. Als Befallsparameter dienten der Befallswert $\left(\mathrm{BBCH} 65 ; \mathrm{R}^{2}=0,67\right)$, die Pflanzenlänge $\left(\mathrm{BBCH} 72 ; \mathrm{R}^{2}=0,82\right)$, und die Sprosstrockenmasse $\left(\mathrm{BBCH} 79 ; \mathrm{R}^{2}=0,57\right)$. Bei einer Inokulumdichte von 200 mg Mikrosklerotien pro 150 g Boden konnte keine stärkere Stauchung des Sprosses bzw. Reduktion der Sprosstrockenmasse im Vergleich zu der Inokulationsstufe mit $100 \mathrm{mg}$ Mikrosklerotien pro $150 \mathrm{~g}$ Boden festgestellt werden. Dies entspricht den Untersuchungen von Heppner 1995, die ab einer bestimmten Verticillium-Inokulumdichte im Boden keine weitere Befallssteigerung nachweisen konnte. Keunecke (2009) führte Inokulationsstufenversuche im Gewächshaus mit Rapsstroh als Inokulum durch, das stark mit V. longisporum befallen war. Dabei konnten keine deutlichen Zusammenhänge zwischen Inokulumdichte im Boden und dem V. longisporum-Befall detektiert werden. Der Vergleich der beiden Inokulationsmethoden zeigt, dass die Inokulation mit Mikrosklerotien die adäquatere Methode ist, um unterschiedliche Inokulumdichten von V. longisporum im Boden zu simulieren.

Aufgrund dieser Ergebnisse erwies sich RCR in Verbindung mit der Bodeninokulation durch Mikrosklerotien als geeignetes System zur Untersuchung eines möglichen Mikrosklerotienabbaus durch M. ochracea. Dabei sind der Befallswert, die Pflanzenlänge und die Sprosstrockenmasse aussagekräftige Parameter zur Erfassung der Höhe des infektiösen Inokulums von $V$. longisporum im Boden.

Zur Untersuchung des antagonistischen Potentials von $M$. ochracea gegenüber Mikrosklerotien von V. longisporum wurde ein Starkinokulationsversuch mit M. ochracea WG durchgeführt. Hierfür wurden 1 g bzw. 5 g M. ochracea WG in 150 g mit Mikrosklerotien beimpften Boden eingemischt und RCR als Modellpflanze ausgesät.

Bei der Bestimmung des DNA-Gehaltes von V. longisporum im Pflanzengewebe mittels Real-time PCR-Analyse und der visuellen Befallsbonitur wurde ein geringerer 
Pflanzenbefall in den Mikrosklerotien + M. ochracea WG inokulierten Varianten im Vergleich zur Positivkontrolle (Mikrosklerotien zugesetzt) ermittelt. Des Weiteren konnte in den mit Mikroskerotien + M. ochracea WG behandelten Varianten ein höherer Sprosstrockenmasseertrag als in der Positivkontrolle festgestellt werden. Dabei wurde bei allen Parametern eine Befallsabstufung mit steigender Aufwandmenge von M. ochracea WG ermittelt.

In den Kontrollvarianten mit M. ochracea WG ohne Mikrosklerotien zeigten sich Wachstumsdepressionen der Rapspflanzen. Somit lieferte die Pflanzenlänge keine aussagekräftigen Ergebnisse in Bezug auf den Befall von Rapspflanzen mit V. longisporum.

Die Wachstumsdepression kann auf den hohen Glukoseanteil in M. ochracea WG zurückgeführt werden. Glukose wird von verschiedenen Mikroorganismen in allelochemische Verbindungen umgesetzt, die phytotoxisch sind und somit das Pflanzenwachstum negativ beeinflussen (Blum et al., 1993; Jilani et al., 2008). Zusätzlich wird durch Zugabe von Glukose die Bodenfungistasis überwunden und die Sporenkeimung induziert (Bristow \& Lockwood, 1975; Yoder \& Lockwood 1973).

In diesem Zusammenhang wurde nicht untersucht, ob es zur Bildung allelochemischer Verbindungen kam und ob M. ochracea daran beteiligt gewesen sein könnte. Es konnte aber nachgewiesen werden, dass durch hohe Inokulationsstufen von M. ochracea WG der Anteil infektiöser Mikrosklerotien im Boden reduziert wird. Dies führte zu einem geringeren Befall der Modellpflanzen mit V. longisporum. Dabei können durch einen hohen Glukoseanteil die Bodenfungistasis überwunden und Sporen von M. ochracea zur Keimung angeregt werden.

In einem weiteren Versuchsansatz wurde das antagonistische Potential von M. ochracea bzw. M. ochracea WG auf Mikrosklerotien von V. longisporum mittels Gießinokulation untersucht. Hierbei sollte die Wirkung von M. ochracea und M. ochracea WG mit praxistauglichen Aufwandmengen für Feldapplikationen getestet werden. Anders als im vorausgegangenen Versuch, fand die Inokulation des mit Mikrosklerotien beimpften Bodens mit einer Sporensuspension von M. ochracea oder M. ochracea WG statt.

In allen mit Mikrosklerotien beimpften Varianten konnte ein Befall der Rapspflanzen mit V. longisporum ermittelt werden. Dabei wurde durch eine Behandlung mit Sporensuspensionen von M. ochracea bzw. M. ochracea WG der Anteil infektiöser Mikro- 
sklerotien im Boden nicht reduziert und somit ließ sich der Befall von RCR mit V. longisporum nicht verringern.

Der Anteil infektiöser Mikrosklerotien im Boden wurde durch eine Gießapplikation mit M. ochracea oder M. ochracea WG im Gegensatz zur Bodeninokulation mit M. ochracea WG als Granulat nicht reduziert. Dabei war die Sporendichte von M. ochracea ein entscheidender Faktor. Wurde bei der Bodeninokulation mit M. ochracea WG als Granulat mit einer hohen Sporendichte inokuliert (8,3 bzw. 1,7 x 107 Sporen/g Boden), so lagen die Aufwandmengen bei der Gießapplikation mit M. ochracea und M. ochracea WG um das ca. 100-fache (2,8 x $10^{5}$ Sporen/g Boden) bzw. 100000-fache (2,8 x 10² Sporen/g Boden) niedriger. Ähnliche Ergebnisse wurden auch bei anderen Untersuchungen erzielt. So berichten Larena et al (2003), dass V. dahliae durch Penicillium oxalicum bei $10^{6}-10^{7} \mathrm{CFU} / \mathrm{g}$ Boden erfolgreich bekämpft werden kann. Geringere Sporengehalte führen hingegen zu keinem Bekämpfungserfolg. Neben der Aufwandmenge spielt bei der Bodeninokulation auch die Formulierung und die Applikationstechnik mit Antagonisten eine entscheidende Rolle für den biologischen Bekämpfungserfolg (Larena et al., 2003; Jones \& Whipps 2002). Sklerotien von S. sclerotiorum werden z.B. deutlich stärker durch C. minitans im Boden parasitiert, wenn C.minitans formuliert als Maismehl-Perlite im Vergleich zur Einarbeitung einer Sporensuspension von C. minitans in den Boden gegeben werden (Jones et al., 2004). M. ochracea WG ist an Glukose als Trägerstoff formuliert. Diese macht einen großen Bestandteil des Produktes aus. Durch die Einmischung von M. ochracea WG in den Boden wurde bei der Bodeninokulation mit M. ochracea WG als Granulat eine Glukosekonzentration von ca. 3\% bzw. 0,6\% im Boden eingestellt. Hingegen lag die Glukosekonzentration bei der Gießapplikation mit M. ochracea WG um das 100-fache bzw. 100000-fache niedriger. Hierbei muss berücksichtigt werden, dass durch hohe Glukosemengen die Bodenfungistasis überwunden und Sporen zum Keimen stimuliert werden können (Bristow \& Lockwood, 1975; Dobbs \& Hinson 1953). Für die Gewächshausversuche diente ein humus- und nährstoffarmes LößlehmVermiculit Gemisch als Bodensubstrat, um mögliche Auswirkungen der Bodenfungistasis gering $\mathrm{zu}$ halten. Dabei stellte sich bei späteren Untersuchungen heraus, dass auch dieses Bodensubstrat eine hohe Fungistasis aufweist, welche durch Zugabe von Glukose teilweise überwunden werden kann. 


\subsection{Feldversuche mit M. ochracea}

Im Herbst 2007 wurden zweijährige Feldversuche mit Winterweizenmonokultur, Winterrapsmonokultur und einer Winterraps-Winterweizen Fruchtfolge angelegt. Gegenstand der Untersuchung war eine mögliche Reduktion des Inokulums der Getreidepathogene P.tritici-repentis (D.tritici-repentis), und M. graminicola (S. tritici). Des Weiteren wurde die Bekämpfung der Rapspathogene L. maculans (P. lingam), und V. longisporum durch $M$. ochracea untersucht. Im folgenden Kapitel wird die Wirkung von M. ochracea auf das Inokulum der phytopathogenen Pilze unter Feldbedingungen diskutiert.

Die Interaktionsstudien zwischen $M$. ochracea und $V$. longisporum unter kontrollierten Bedingungen zeigten ein hohes antagonistisches Potential von $M$. ochracea unter verschiedenen Umwelteinflüssen. Diese Ergebnisse stellen gute Vorraussetzungen für die erfolgreiche Etablierung von M. ochracea als pilzlichen Antagonisten unter Feldbedingungen dar. Von anderen Antagonisten wird hingegen berichtet, dass in in vitro erzielte Wirkungserfolge nicht auf mögliche biologische Bekämpfungserfolge im Freiland schließen lassen. So wurde z.B. in in vitro-Versuchen nachgewiesen, dass C. minitans ein hohes mykoparasitisches Potential gegenüber verschiedenen sklerotienbildenenen phytopathogenen Pilzen besitzt. Unter Feldbedingungen zeigt sich hingegen, dass C. minitans nur Sklerotien verschiedener Sclerotinia spp. parasitiert (Fravel, 2005; Wafaa \& Haggag, 1999; Turner \& Tribe, 1976; Turner, 1975). Dabei können neben den in vitro untersuchten Umweltfaktoren, auch das osmotische Potential, das Wasserpotential, die Salzkonzentration, die Bodentextur, Regenereignisse und die Präsenz von natürlich vorkommenden Antagonisten im Boden die Antagonisten negativ beeinflussen (Kredics et al., 2003; Handelsman \& Stabb, 1996; Larkin \& Fravel, 2002). Somit ist der biologische Bekämpfungserfolg stroh- und bodenbürtiger phytopathogener Pilze unter Feldbedingungen von sehr vielen Faktoren abhängig.

Die Getreidepathogene P.tritici-repentis, M. graminicola und das Rapspathogen L. maculans bilden Pseudothezien auf Ernterückständen. Bei früheren Untersuchungen von Carisse et al., (2000) wurde eine mykoparasitische Wirkung durch M. ochracea auf Pseudothezien von V. inaequalis nachgewiesen. Dabei kann durch Herbstbehandlung der Apfelplantagen mit $M$. ochracea die Askosporenproduktion ausgehend von Pseudothezien des Erregers $V$. inaequalis, reduziert werden. Dies führt zu einem 
verminderten Apfelschorfbefall im folgenden Jahr (Carisse et al., 2000; Carisse \& Rolland, 2004).

Im Winterweizenmonokulturversuch wurde bei der DTR-Befallsbonitur im Jahr 2008 keine Befallsreduktion durch Behandlungen mit M. ochracea WG nachgewiesen. Im Jahr 2009 konnte der DTR-Befall durch Behandlungen mit M. ochracea WG reduziert werden. Dabei zeigte sich zum ersten Boniturtermin eine DTR-Befallsreduktion in der im Herbst mit 2 kg/ha M. ochracea WG behandelten Variante und den mit $1 \mathrm{~kg} / \mathrm{ha}$ und $2 \mathrm{~kg} / \mathrm{ha}$ M. ochracea WG im Herbst und im Frühjahr behandelten Varianten im Vergleich zur unbehandelten Kontrolle. Beim zweiten Boniturtermin wurde durch die Herbstbehandlung mit 1 kg/ha M. ochracea WG und die Doppelbehandlung im Herbst und im Frühjahr mit 2 kg/ha M. ochracea WG eine signifikante Reduktion des Befalls mit DTR erzielt. Im Jahr 2008 ließ sich beim ersten Boniturtermin eine Reduktion des Befalls mit S. tritici durch Doppelbehandlungen (2kg/ha M. ochracea WG) feststellen. Ähnlich dazu wurden beim zweiten Boniturtermin leichte bzw. signifikante Reduktionen des Befalls mit S. tritici ermittelt. Dabei konnte eine deutliche Befallsreduktion mit steigender Behandlungsfrequenz bzw. Aufwandmenge von M. ochracea WG beobachtet werden.

Ähnliche Effekte wurden für P. lingam beim Winterrapsmonokulturversuch ermittelt. Durch Behandlungen mit M. ochracea WG wurde der Befall mit P. lingam deutlich reduziert. Dabei kam es zu einer stärkeren Befallsreduktion mit Erhöhung der Aufwandmenge von M. ochracea WG und einer Durchführung von Doppelbehandlungen. Im Jahr 2009 waren diese Effekte im Vergleich zum Jahr 2008 deutlich stärker ausgeprägt. Im Fruchtfolgeversuch mit Winterraps und Winterweizen führten Doppelbehandlungen mit M. ochracea WG hingegen zu keiner Reduktion des Befalls durch P. lingam.

Der Vergleich der Ergebnisse zeigt deutlich, dass die Applikationshäufigkeit und menge von M. ochracea WG einen Einfluss auf das Befallsgeschehen pseudothezienbildender phytopathogener Pilze an Kulturpflanzen haben. Dies würde die Ergebnisse der Laboruntersuchungen und der Gewächshausversuche bestätigen, dass mit höheren Sporendichten der Wirkungsgrad von M. ochracea gesteigert wird.

In den hier dargestellten Feldversuchen wurde eine Sporenkonzentration von 2,5 x $10^{12}$ Sporen/ha (1 $\mathrm{kg} / \mathrm{ha} \quad$ M. ochracea WG) bzw. 5 x $10^{12}$ Sporen/ha $(2 \mathrm{~kg} / \mathrm{ha}$ M. ochracea WG) von M. ochracea appliziert. Es kam teilweise zu einem geringeren 
Pathogenbefall bei höheren Aufwandmengen von M. ochracea WG. Die Erhebungen von Carisse et al, (1999) zeigten einen deutlichen Bekämpfungserfolg mit 5 x $10^{11}$ Sporen/ha von $M$. ochracea für die Bekämpfung von $V$. inaequalis in Apfelplantagen, und mit $1 \times 10^{14}$ Sporen/ha für eine wirksame Bekämpfung von B. squamosa im Zwiebelanbau (Carisse et al., 2006). Jedoch liegen bisher keine Untersuchungen über die Auswirkungen unterschiedlicher Aufwandmengen auf den biologischen Bekämpfungserfolg eines Organismus unter Feldbedingungen in der Literatur vor.

Für C. minitans sind widersprüchliche Ergebnisse beschrieben. In manchen Jahren führten höhere Aufwandmengen von C. minitans zu einer stärkeren Befallsreduktion mit S. sclerotiorum, wohingegen in anderen Jahren keine Befallsunterschiede zwischen unterschiedlichen Aufwandmengen festgestellt wurden. (Partridge et al., 2006).

Bei den hier dargestellten Untersuchungen wurde teilweise ein höherer biologischer Bekämpfungserfolg durch Doppelbehandlungen mit M. ochracea WG erzielt. In früheren Untersuchungen wurde nachgewiesen, dass bei der biologischen Bekämpfung des Inokulums von $V$. inaequalis durch $M$. ochracea der Applikationstermin und die behandelte Zielfläche einen entscheidenden Einfluss auf die Wirkungssicherheit von M. ochracea als biologisches Pflanzenschutzmittel hatten. Dabei führte eine frühe Blattbehandlung mit M. ochracea zu einer stärkeren Reduktion des Inokulums von V. inaequalis im Vergleich zu späten Bodenbehandlungen(Carisse et al., 2000; Carisse \& Rolland, 2004). Ferner führten mehrmalige Applikationen von M. ochracea zu einer deutlich besseren Reduktion des Inokulums phytopathogener Pilze (Carisse et al., 2006).

Bislang existieren nur wenige Untersuchungen über die Mykoparasitierung von Pseudothezien phytopathogener Pilze. Doch berichten verschiedene Studien, dass durch Saatgut- und Blattbehandlungen mit verschiedenen Trichoderma spp. der Befall von Winterweizen mit S. tritici und DTR reduziert werden kann (Perello et al., 2006; Perello et al., 2009). Des Weiteren führten Inokulationen von Rapsstoppeln mit dem Pilz Cyathus olla zum Abbau strohbürtiger Krankheitserreger und somit auch zum Abbau der Pseudothezien von L. maculans (Shinners \& Tewari, 2000). Pfender et al. (1993) konnten in Feldversuchen nachweisen, dass durch eine Behandlung von Weizenstroh mit Limonomyces roseipellis die Pseudothezienbildung durch $P$. tritici-repentis reduziert wird. Dabei konnte nach einer Inokulation der Ernterückstände mit diesem Basidiomyceten ein Rückgang der Askosporenproduktion um 50-90\% festgestellt 
werden (Pfender, 1988). Es scheint, dass M. ochracea einerseits ähnlich wie L. roseipellis die Pseudothezienbildung reduziert, andererseits aber auch in der Lage ist, Pseudothezien zu parasitieren. Somit wird die Askosporenproduktion reduziert, wodurch es zu einem geringeren Befall von Winterweizen und Winterraps mit pseudothezienbildenden phytopathogenen Pilzen kam.

Während zur Bekämpfung der Getreide- und Rapspathogene S.tritici, DTR und $P$. lingam ein breites Sortiment an Fungiziden zur Verfügung steht, existieren keine fungizidbasierten Bekämpfungsstrategien zur Reduktion des Befalls von Raps mit V. longisporum. Daher wäre ein integriertes System auf Basis von Antagonisten zur Bekämpfung der Mikrosklerotien von V. longisporum im Boden hilfreich.

Nach Untersuchungen von Carisse et al, (2001, 2006) kann M. ochracea in vitro, aber auch unter Feldbedingungen die Sklerotienbildung von R. solani und B. squamosa unterbinden bzw. ist in der Lage, die Sklerotien zu parasitieren und sie an ihrer Keimung zu hindern. Im Rahmen dieser Arbeit wurde zusätzlich eine antagonistische Wirkung von $M$. ochracea auf Mikrosklerotien von $V$. longisporum in vitro nachgewiesen.

Somit wurde in dem Winterrapsmonokulturversuch und dem Winterraps-Winterweizen Fruchtfolgeversuch eine mögliche Reduktion des Inokulums von $V$. longisporum durch M. ochracea untersucht.

Durch Behandlungen mit M. ochracea WG konnte in keinem Versuchsjahr eine Verringerung infektiöser Mikrosklerotien im Boden und damit ein verminderter Rapspflanzenbefall mit $V$. longisporum ermittelt werden. Die viel versprechenden Ergebnisse aus den Labor- und Gewächshausversuchen zur biologischen Bekämpfung der Mikrosklerotien von $V$. longisporum durch $M$. ochracea konnten somit leider nicht in den Feldversuchen bestätigt werden.

In vitro sind viele verschiedene Pilze und Bakterien als potentielle Antagonisten von Verticillium spp. beschrieben (Danielson et al., 2007; Debode et al., 2007; Berg et al., 2005). Aber nur wenige Organismen können ihre antagonistische Wirkung auf Inokulum von Verticillium spp. in unsterilem Boden entfalten und somit den Befall von Pflanzen durch Verticillium spp. reduzieren (Müller \& Berg, 2008; Fahima et al., 1992). In den Feldversuchen wurde, außer in der Herbstbehandlung mit $2 \mathrm{~kg} / \mathrm{ha}$ M. ochracea WG des Winterraps-Winterweizen-Fruchtfolgeversuches keine Ertrags- 
steigerung durch Behandlungen mit M. ochraceaWG ermittelt. Hierbei muss festgehalten werden, dass nur selten eine Ertragssteigerung durch den Einsatz von biologischen Pflanzenschutzmitteln auf Basis von Antagonisten im Getreide- und Rapsanbau erreicht werden kann (Knudsen et al., 1995). Dies steht im Gegensatz zum Gemüseanbau. Dort kann durch eine Applikation mit biologischen Pflanzenschutzmitteln der Ertrag an vermarktungsfähiger Ware gesteigert werden was auf die Reduktion des pilzlichen Pathogenbefalls zurückzuführen ist (Budge \& Whipps, 1991; Datnoff et al., 1995). Somit ist der Einsatz biologischer Pflanzenschutzmittel im Getreide- und Rapsanbau keine adäquate Maßnahme zur einmaligen Ertragssteigerung und -sicherung, sondern mehr eine effiziente Möglichkeit zur langfristigen Reduktion des bodenbürtigen Inokulums von Fruchtfolgekrankheiten wie z.B. S. sclerotiorum (Gerlagh et al., 1999).

\subsection{Interaktion zwischen $M$. ochracea und V. longisporum im Boden}

Ein Teilbereich dieses Forschungsvorhabens beschäftigte sich mit dem Abbau von Inokulum von $V$. longisporum durch $M$. ochracea im Boden. Hierfür wurden Versuche unter kontrollierten Bedingungen mit sterilem bzw. unsterilem Rapsstroh in sterilen bzw. unsterilen Bodensubstraten durchgeführt. Darüber hinaus sind in den Versuchsjahren 2007/2008 und 2008/2009 Littebagversuche mit unsterilem Rapsstroh im Institutsgarten Göttingen-Weende bzw. auf Ackerflächen der Universität Göttingen durchgeführt worden. In weiteren Versuchsansätzen wurden die Auswirkungen der Bodenfungistasis auf die Sporenkeimung von M. ochracea in verschiedenen Böden untersucht. Die Ergebnisse dieser Studie sollen im folgenden Kapitel diskutiert und kritisch beleuchtet werden.

Durch Untersuchungen in vitro wurde ein hohes mykoparasitisches Potential von M. ochracea über einen breiten Temperatur- und $\mathrm{pH}$-Bereich festgestellt. Des weiteren hatte Licht keinen Einfluss auf die antagonistische Wirkung von M. ochracea auf Mikrosklerotien von V.longisporum. Dies stellte gute Vorraussetzungen für die Etablierung von M. ochracea als Antagonist phytopathogener Pilze im Boden dar. Neben den untersuchten Umweltfaktoren haben auch die Salzkonzentration, Rückstände von Pflanzenschutzmitteln, die Bodenart und die biotische und abiotische Bodenfungistasis einen enscheidenden Einfluss auf das Wachstum, die Wirkung und die Reproduktion von Antagonisten im Boden (Kredics et al., 2003; Handelsman \& v 
Stabb, 1996; Larkin \& Fravel, 2002; Watson \& Ford, 1972). So ist C. minitans als erfolgreicher Mykoparasit in der Lage abgestorbenes Pflanzengewebe und Sklerotien zu besiedeln und sich auf diesen zu vermehren (Gerlagh et al., 1994; Benett et al., 2006). Dabei können Sporen von C. minitans in Abhängigkeit von der Temperatur und der Bodenfeuchtigkeit bis zu 18 Monate in Sklerotien verschiedener Sclerotinia spp. im Boden überdauern (Whipps \& Gerlach, 1992; Benett et al, 2006). Ausgehend von den infizierten Sklerotien breitet sich C. minitans im Boden aus und parasitiert neue Sklerotien (McQuilken et al., 1995; Yang et al., 2009). Auf der Basis eigener Ergebnisse und Berichten von Carisse \& Bernier (2002) ist M. ochracea in der Lage, abgestorbenes Pflanzengewebe und somit auch Rapsstroh zu besiedeln. Dabei ist das Wachstum und die Vermehrung von Antagonisten im Boden für eine erfolgreiche biologische Bekämpfung bodenbürtiger, phytopathogener Pilze von maßgeblicher Wichtigkeit.

In Quarkschalentests wurde eine mögliche Reduktion des Inokulums von $V$. longisporum durch $M$. ochracea untersucht. Hierfür fand eine Inokulation steriler Rapsstängel, die durch Mikrosklerotien bewachsenen waren, mit M. ochracea bzw. Wasser statt. Anschließend wurden sie in sterilem Sand bzw. unsteriler Erde inkubiert. Nach der Inkubation in unsteriler Erde konnten keine unterschiedlichen DNA-Gehalte von $V$. longisporum zwischen der Wasserkontrolle und der mit M. ochracea behandelten Variante ermittelt werden. Im Gegensatz dazu wurde nach der Inkubation in sterilem Sand ein geringerer DNA-Gehalt von V. longisporum in der mit M. ochracea behandelten Variante im Vergleich zur Wasserkontrolle gemessen.

M. ochracea wurde mittels PCR-Verfahren auf allen mit $M$. ochracea inokulierten, und in sterilem Sand inkubierten Rapsstängeln eindeutig nachgewiesen. Demgegenüber konnte $M$. ochracea nach der Inkubation behandelter Rapsstängel in unsteriler Erde nur in einer Probe nachgewiesen werden. Ähnliche Untersuchungen wurden von Gerlagh et al., (1996) mit C. minitans durchgeführt. Demnach kommt es während der Inkubation auf sterilem Sand zu einer hohen Reproduktionsrate von C.minitans auf Tomatenstängeln. Im Unterschied dazu fand während der Inkubation auf unsteriler Erde nur eine geringe Besiedlung der Tomatenstängel durch C. minitans statt.

In einem weiteren Versuchsansatz wurde das Wachstum von M. ochracea auf unsterilen und stark mit Mikrosklerotien von V.longisporum bewachsenen Rapsstängeln untersucht. Dabei konnte $M$. ochracea ausschließlich in zwei Proben nach der 
Inkubation auf unsterilem Sand und in sterilem Sand nachgewiesen werden. Hierbei muss beachtet werden, dass es sich nicht feststellen ließ, inwieweit DNA aus abgestorbenen Zellen zu falsch positiven PCR-Nachweisen führte.

Festzuhalten gilt, dass M. ochracea in der Lage ist, Mikrosklerotien von V. longisporum während der Inkubation in sterilem Sand zu parasitieren und Rapsstängel zu besiedeln. Dabei könnte neben der Mykoparasitierung, die bereits in vorherigen Untersuchungen festgestellte und von Whipps (2001) und Alabouvette et al, (2006) beschriebene Konkurrenz um Nährstoffe und Raum zwischen Antagonist und Pathogen eine entscheidende Rolle in dem antagonistischen System spielen.

In Litterbagversuchen wurde der Abbau der Mikrosklerotien von V. longisporum durch M. ochracea WG unter Feldbedingungen untersucht. Eine mögliche Reduktion des Inokulums von $V$. longisporum während der Litterbagversuche wurde indirekt mittels Biotest im Gewächshaus überprüft. Dabei konnte in keinem Versuch ein Abbau von Mikrosklerotien durch M. ochracea WG nachgewiesen werden. Die Biotests zeigten für die Rapspflanzen teilweise geringere Pflanzenlängen und Sprosstrockenmassen in der mit M. ochracea WG behandelten Variante im Vergleich $\mathrm{zu}$ den dazugehörigen Kontrollen. Dies ist ein Indiz für einen stärkeren Befall der Rapspflanzen mit $V$. longisporum und somit einem höheren Inokulumbesatz von V. longisporum in den Proben der mit M. ochracea WG inokulierten Varianten.

Bereits im Herbst 2007 wurde eine Beprobung der Litterbagversuche durchgeführt. Bei der Untersuchung des DNA-Gehaltes von V. longisporum mittels Real-time PCR wurde in $10 \mathrm{~cm}$ und $20 \mathrm{~cm}$ Bodentiefe ein höherer DNA-Gehalt von $V$. longisporum auf den mit M. ochracea WG inokulierten Rapsstängeln im Vergleich zu den Kontrollvarianten gemessen. Es muss berücksichtigt werden, dass M. ochracea WG an Glukose formuliert ist und die Tauchinokulation der Litterbags in Sporensuspension von M. ochracea WG erfolgte. Bei einer Sporendichte von 8 x $10^{6}$ Sporen/ml waren in der Inokulationslösung ca. 0,3\% Glukose enthalten. In früheren Studien wurde festgestellt, dass die Bodenfungistasis keine Auswirkung auf die Konidienkeimung von Verticillium albo-atrum hat (Hora et al., 1977). Darüber hinaus wird durch Zugabe von 0,1\%iger Saccharoselösung die Mikrosklerotienkeimung im Boden stimuliert (Farley et al., 1971). Diese Untersuchungsergebnisse und die erhöhten DNA-Gehalte von V. longisporum in den Rapsstängeln der Herbstbeprobung, die mit M. ochracea WG inokuliert wurden, untermauern die Beobachtungen aus den Biotests. Somit kam es durch den Glukoseanteil in 
der Inokulationslösung von M. ochracea WG zu einer vermehrten Mikrosklerotienkeimung auf Rapsstängeln und dadurch zu einem stärkeren Myzelwachstum von $V$. longisporum. In eigenen Untersuchungen konnte festgestellt werden, dass die Bodenfungistasis einen negativen Einfluss auf die Sporenkeimung von M. ochracea hat. Die Bodenfungistasis wird erst bei Zugabe höherer Glukosekonzentrationen überwunden, so dass die Sporenkeimung von M. ochracea erst dann angeregt wird.

Die Besiedlung des Probenmaterials der Litterbagversuche mit M. ochracea wurde mittels PCR untersucht. DNA von M. ochracea ließ sich in allen inokulierten und im Herbst 2007 genommenen Proben nachweisen. Die im darauf folgenden Frühjahr 2008 entnommenen Proben zeigten beim PCR-Nachweis keine DNA-Gehalte von M. ochracea.

Dabei muss berücksichtigt werden, dass bei PCR-Untersuchungen DNA aus toten und lebenden Zellen erfasst wird (Schaad \& Frederick, 2002; Henson et al., 1993). Somit ist der positive Nachweis von M. ochracea auf den im Herbst 2007 geborgenen Proben vorraussichtlich auf nicht gekeimte bzw. abgestorbene Sporen von M. ochracea zurückzuführen.

Im Versuchsjahr 2008/2009 wurde M. ochracea über das PCR-Nachweisverfahren nur vereinzelt in mit M. ochracea WG inokulierten Rapsstängelproben nachgewiesen, die in 10 und $20 \mathrm{~cm}$ Bodentiefe inkubiert und im Frühjahr 2009 geborgenen wurden. Anders als im Versuchsjahr 2007/2008 fand die Inkubation der Proben nach der Inokulation mit M. ochracea WG im Herbst 2008 für eine Woche in Feuchteboxen statt und wurden anschließend vergraben. Durch die Vorinkubation konnten Sporen von M. ochracea keimen und die Rapsstängel besiedeln, ohne den Auswirkungen der Bodenfungistasis ausgesetzt zu sein.

Die Analyse der Proben aus den Interaktionsversuchen zwischen V. longisporum und M. ochracea mittels PCR zeigte bei vielen Proben Hemmungen der PCR-Reaktionen. Die Hemmungen sind auf PCR-Inhibitoren in den DNA-Extrakten zurückzuführen. Diese können die PCR-Reaktionen vollständig zum Erliegen bringen bzw. die PCREffizienz vermindern (Wilson 1997; Monteiro et al., 1997). Somit könnten PCRInhibitoren beim Nachweis von $M$. ochracea mittels PCR zu falsch negativen Ergebnissen geführt haben. 
In einem weiteren Versuchsansatz wurde die Besiedlung unsteriler, befallsfreier Rapsstängel durch $M$. ochracea unter Feldbedingungen untersucht. Hierzu fand eine Inokulation von Rapsstängel mit Sporensuspensionen von $M$. ochracea bzw. M. ochracea und V. longisporum statt. Diese wurden anschließend auf der Bodenoberfläche und in $5 \mathrm{~cm}$ Bodentiefe inkubiert. Im Folgenden Frühjahr konnte eine Pyknidienbildung durch $M$. ochracea auf allen mit $M$. ochracea inokulierten und auf der Bodenoberfläche inkubierten Rapsstängeln beobachtet werden. Durch eine PCRAnalyse wurde M. ochracea im entsprechenden Probenmaterial nachgewiesen. Dabei zeigten die mit M. ochracea inokulierten und in $5 \mathrm{~cm}$ Bodentiefe inkubierten Rapsstängel weder eine Pyknidienbildung, noch konnte M. ochracea mittels PCRUntersuchung festgestellt werden.

In den eigenen und den vorausgegangenen Studien von Carisse \& Bernier (2002) konnte ermittelt werden, dass Licht unter kontrollierten Bedingungen einen wesentlichen Einfluss auf die Pyknidienbildung von M. ochracea hat. Diese Ergebnisse zeigen, das Licht auch unter Freilandbedingungen die Reproduktion von M. ochracea auf Rapsstroh begünstigt. Bei Lichtausschluss (in $5 \mathrm{~cm}$ Bodentiefe) konnte sich M. ochracea auf Rapsstängeln nicht etablieren.

Die Interaktionsstudien zwischen $M$. ochracea und $V$. longisporum im Boden haben gezeigt, dass $M$. ochracea seine antagonistische Wirkung unter diesen Bedingungen nicht entfalten konnte. M. ochracea zeigt seine antagonistische Wirkung auf phytopathogene Pilze im Boden nur bei hohen Sporendichten in Gewächshausversuchen, einem hohen Anteil an Glukose und in sterilem Sand. So scheint die Bodenfungistasis, ähnlich wie bei anderen Antagonisten (Papavizas, 1985; Benett et al., 2003), die Sporen von M. ochracea in unsterilem Boden an der Keimung zu hindern.

Aufgrund dieser Beobachtungen wurde die Auswirkung der Bodenfungistasis auf die Sporenkeimung von $M$. ochracea untersucht. In verschiedenen Arbeiten konnte nachgewiesen werden, dass Sporen verschiedener Pilze unterschiedlich stark durch die Bodenfungistasis in ihrer Keimung gehemmt werden (Dix, 1972; Lee et al., 1985). Dabei kann die Bodenfungistasis durch Pasteurisieren, Autoklavieren bzw. die Zugabe von Saccharose oder Glukose überwunden werden (Hora \& Baker, 1972, Bristow \& Lockwood, 1975; Dobbs \& Hinson, 1953.). 
In Laboruntersuchungen wurde die Sporenkeimung von M. ochracea auf frischen und autoklavierten Böden näher betrachtet. Anhand mikroskopischer Untersuchungen wurde nachgewiesen, dass Sporen von M. ochracea auf frischen Bodensubstraten nicht keimen (Abb. 15 links). Auf autoklavierten Bodensubstraten konnte hingegen eine Sporenquellung, Sporenkeimung und Keimschlauchbildung festgestellt werden (Abb. 15 rechts). Beim Vergleich der Sporenkeimung auf verschiedenen frischen Bodensubstraten zeigte hingegen nur die Variante auf „Felderde“ eine geringe Sporenkeimung von M. ochracea. Durch Autoklavieren der Bodensubstrate konnte die Bodenfungistasis überwunden werden. In einem anschließenden Keimtest zeigten sich unterschiedliche Sporenkeimraten von M. ochracea zwischen den verschiedenen Bodensubstraten (Abb. 16).

In einer Vielzahl von Untersuchungen wurde aufgezeigt, dass die Bodenfungistasis durch biotische und abiotische (Mykostasis) Faktoren ausgelöst wird. Dabei kommt den biotischen Faktoren die größere Bedeutung zu (Watson \& Ford, 1972; de Boer et al., 2003; Dobbs \& Gash, 1965). Die keimhemmende Wirkung der Mykostasis auf Sporen im Boden ist abhängig von der untersuchten Pilzart, dem $\mathrm{CaCO}_{3}$-Gehalt und dem Anteil freier bzw. chelatisierter Eisen- und Aluminiumionen. Dabei kann die Mykostasis, gegensätzlich zur biotischen Fungistasis, nicht durch Autoklavieren der Bodensubstrate überwunden werden (Ko \& Hora, 1972; de Boer et al., 2003; Dobbs \& Gash, 1965).

Somit sind unterschiedliche Sporenkeimraten von $M$. ochracea zwischen den verschiedenen autoklavierten Erdsubstraten (Felderde, Bot. Garten, Dauergrünland) (Abb. 16) auf stark divergierend wirkende mykostatische Effekte in den Bodensubstraten zurückzuführen.

In einem weiteren Versuchsansatz konnte durch Zugabe von Glukoselösung zu frischem Bodensubstrat die Sporenkeimrate von M. ochracea gesteigert werden. Dabei wurden bei höheren Glukosekonzentrationen ansteigende Sporenkeimraten ermittelt. Anders als bei der Variante mit „Felderde“ konnte durch Autoklavieren von Lößlehm die Fungistasis nur teilweise überwunden werden. Daraus lässt sich schließen, dass Lößlehm einen hohen Anteil abiotisch (mykostatischer) und biotisch wirkender fungistatischer Verbindungen enthält.

In früheren Untersuchungen wurde nachgewiesen, dass Sporen von C. minitans durch den Einfluss der Bodenfungistasis an der Keimung gehemmt werden. Diese überdauern 
ungekeimt über längere Zeit im Boden, bis sie durch Sklerotien zur Keimung stimuliert werden (Benett et al., 2006; Whipps \& Gerlagh, 1991; Kaur et al., 2005; Ridgway \& Stewart, 2000). Somit können Sklerotien von S. sclerotiorum in sterilem und in unsterilem Boden durch C. minitans parasitiert werden (Benett et al., 2005). Benyagoub et al. (1998) konnten in ihren Untersuchungen ein gesteigertes Myzelwachstum von M. ochracea bei Kontakt mit Myzel von $V$. inaequalis beobachten. Darüber hinaus stellten sie fest, dass strukturlösende Enzyme eine entscheidende Rolle bei der Parasitierung von Pathogenzellen durch M. ochracea spielen. Dabei scheint eine besondere Attraktivität von melanisierten Strukturen für die Parasitierung durch M. ochracea auszugehen (Bassam et al., 2002). In der Rinde der Sklerotien von S. sclerotiorum wurde Melanin nachgewiesen (Jones, 1970). Dieses könnte als möglicher Stimulator für die Parasitierung der Sklerotien durch M. ochracea fungieren.

Durch in vitro-Untersuchungen zeigte Carisse (2001), dass Sklerotien von S. sclerotiorum durch M. ochracea parasitiert werden. Aufgrund dieser Ergebnisse wurde im Rahmen einer Bachelorarbeit die Parasitierung der Sklerotien von S. sclerotiorum durch C. minitans und M. ochracea in vitro untersucht (Brandes unveröffentlicht, 2008). Dabei stellte sich heraus, dass Sklerotien von S. sclerotiorum sowohl durch M. ochracea als auch von C. minitans parasitiert und in ihrer Keimung gehemmt werden. Daraufhin wurde im Versuchsjahr 2008/2009 die Parasitierung von Sklerotien durch C. minitans und M. ochracea in unsterilem Boden im Gewächshaus untersucht. Durch Behandlungen mit C. minitans zeigte sich, dass die Sklerotien parasitiert und die Sklerotienkeimung und Apothezienbildung verhindert werden. Behandlungen mit $M$. ochracea führten hingegen zu keiner reduzierten Sklerotienkeimung und Apothezienbildung (Abb. 4 Anhang).

Diese Untersuchungen untermauern die Ergebnisse der Interaktionsversuche zwischen V. longisporum und M. ochracea in unsterilem Boden. Die Sporenkeimung von M. ochracea in unsterilen Böden wird durch die Bodenfugistasis unterdrückt. Somit können die Überdauerungsstrukturen bodenbürtiger phytopathogener Pilze nicht durch M. ochracea parasitiert und an ihrer Keimung gehemmt werden. Darüber hinaus kann durch den direkten Kontakt mit Sklerotien, anders als bei Sporen von C. minitans, die Sporenkeimung von $M$. ochracea nicht induziert werden. 
Zusammenfassend lassen die vorgestellten Ergebnisse den Schluss zu, dass M. ochracea kein Potential zur Reduktion des Inokulums bodenbürtiger phytopathogener Pilze in unsterilen Böden hat. 


\section{Ausblick}

Die Intensivierung des Getreide- und Rapsanbaus in Verbindung mit reduzierter Bodenbearbeitung, führt zu einer vermehrten Anreicherung von Inokulum phytopathogener Pilze auf Ernterückständen in den oberen Bodenschichten. Darüber hinaus stehen durch ein immer strenger werdendes Pflanzenschutzmittelgesetz weniger fungizide Wirkstoffe zur effizienten Bekämpfung phytopathogener Pilze im Getreide- und Rapsanbau zur Verfügung. Ein weiteres, immer stärker auftretendes Problem im Rapsanbau ist das bodenbürtige Pathogen V. longisporum. Dieser Krankheitserreger kann in Form von Mikrosklerotien mehrere Jahre im Boden überdauern. Dabei stehen den Landwirten keine geeigneten Fungizidstrategien zur Bekämpfung von V. longisporum im Rapsanbau zur Verfügung.

In den letzten Jahren wurden weltweit immer mehr biologische Pflanzenschutzmittel zugelassen. Dabei bietet die Eingliederung biologischer Fungizide auf der Basis von Antagonisten im integrierten Pflanzenschutz die Möglichkeit, Resistenzen gegenüber Fungiziden zu brechen und bodenbürtige pilzliche Schaderreger nachhaltig zu bekämpfen. Damit sich biologische Fungizide in der praktischen Landwirtschaft behaupten können, müssen diese leicht zu handhaben sein, einen hohen Wirkungsgrad bzw. eine hohe Wirkungssicherheit aufweisen und zu Ertragssteigerungen bzw. Qualitätsverbesserungen bei Ernteprodukten führen.

Im Rahmen dieser Arbeit wurde eine mögliche Reduktion des stroh- und bodenbürtigen Inokulums der Getreidepathogene D. tritici-repentis, G. zeae, M. graminicola und der Rapspathogene L.maculans, V. longisporum durch den pilzlichen Antagonisten M. ochracea untersucht. Dabei wurde in in vitro-Studien ein hohes antagonistisches Potential von $M$. ochracea auf Myzel und Überdauerungsformen der Getreide- und Rapspathogene festgestellt. In Feldversuchen wurde durch Spritzapplikation von M. ochracea auf Ernterückstände von Winterraps und Winterweizen das Inokulum der pseudothezienbildenden Getreidepathogene D. tritici-repentis, M. graminicola und des Rapspathogens L. maculans reduziert, was zu einem verminderten Kulturpflanzenbefall im Folgejahr führte. Im Gegensatz dazu konnte durch eine Spritzapplikationen mit M. ochracea das infektiöse Inokulum von V. longisporum auf Ernterückständen und im Boden nicht reduziert werden. Darüber hinaus wurde weder bei Winterweizen, noch bei Winterraps eine Steigerung des Kornertrages durch Behandlungen mit M. ochracea 
erzielt. In weiteren Untersuchungen zeigte sich, dass Umwelteinflüsse wie ein mangelndes Lichtangebot und die Bodenfungistasis einen negativen Einfluss auf die Reproduktion von M. ochracea im Boden haben.

Aufgrund dieser Ergebnisse zeigt sich, dass M. ochracea die Anforderungen an ein biologisches Pflanzenschutzmittel nicht erfüllt. Durch den Einsatz von M. ochracea unter Feldbedingungen kann weder eine Wirkungssicherheit auf pilzliche Pathogene, eine Ertragssteigerung des Erntegutes, noch eine nachhaltige Bekämpfung bodenbürtiger pilzlicher Pathogene ( $V$. longisporum) und ihrer Überdauerungsformen gewährleistet werden. Somit wird sich M. ochracea als biologisches Pflanzenschutzmittel nicht in der Landwirtschaftlichen Praxis behaupten können.

Schlussendlich machen diese Ergebnisse deutlich, dass ähnlich zu vielen anderen antagonistischen Systemen, Wirkungserfolge unter kontrollierten Bedingungen nicht auf die Wirkung der Antagonisten unter Freilandbedingungen übertragen werden können. 


\section{Zusammenfassung}

Im Rahmen der vorliegenden Arbeit wurde der Abbau des Inokulums stroh- und bodenbürtiger phytopathogener Pilze im Getreide- und Rapsanbau durch den pilzlichen Antagonisten Microsphaeropsis ochracea untersucht. Ziel der Untersuchung war es zu klären, ob sich dieser Organismus als Grundlage für ein neues biologisches Pflanzenschutzmittel eignet. Dabei wurde der Schwerpunkt auf einen möglichen Abbau von Inokulum des bodenbürtigen phytopathogenen Pilzes Verticillium longisporum an Raps gelegt. Hierzu fanden Interaktionsstudien in in vitro-, Gewächshaus-, Litterbag- und Feldversuchen statt. In weiteren Feldversuchen sollte festgestellt werden, ob eine Behandlungen von Ernterückständen von Winterraps und Winterweizen mit M. ochracea die Inokulumproduktion von Mycosphaerella graminicola, Pyrenophora tritici-repentis und Leptosphaeria maculans vermindern, und somit der Kulturpflanzenbefall reduziert werden kann.

Für Interaktionsstudien zwischen M. ochracea und Verticillium spp. wurde ein in vitroPlattentest entwickelt. Dieser erwies sich als geeignet um die Wirkung von M. ochracea auf die Keimung von Mikrosklerotien von Verticillium spp. in Abhängigkeit von verschiedenen Umweltfaktoren zu untersuchen. M. ochracea zeigte eine stark keimhemmende Wirkung auf Mikrosklerotien von $V$. longisporum über einen weiten Temperaturbereich $\left(4^{\circ} \mathrm{C}\right.$ bis $\left.24^{\circ} \mathrm{C}\right)$. Der antagonistische Wirkungsgrad von $M$. ochracea auf Mikrosklerotien von $V$. longisporum konnte durch eine Erhöhung der M. ochraceaInokulumdichte und die Verlängerung der Inkubationsdauer verstärkt werden. In weiteren Untersuchungen wurde nachgewiesen, dass Licht die Pyknidienbildung von M. ochracea auf Rapsstängeln und Nährmedium begünstigt. Doch konnte kein Einfluss von Licht auf die antagonistische Wirkung von M. ochracea auf Mikrosklerotien von $V$. longisporum ermittelt werden. Neben den Umweltfaktoren beeinflusste auch die Verticilliumart den biologischen Bekämpfungserfolg. Dabei hatte M. ochracea eine stärker keimhemmende Wirkung auf Mikrosklerotien von $V$. longisporum im Vergleich zu Mirosklerotien von $V$. dahliae.

In Interaktionsstudien zwischen $M$. ochracea und V. longisporum auf sterilen Rapsstängeln zeigte sich, dass durch Inokulation mit M. ochracea die Mikrosklerotienbildung von $V$. longisporum verhindert werden kann. 
Zum sensitiven Nachweis von M. ochracea wurde ein PCR-basiertes Nachweisverfahren entwickelt. Ausgehend von der rDNA-Sequenz der „Internal Transcribed Spacer“ (ITS) Region von M. ochracea wurden Primer abgeleitet. Diese erwiesen sich als geeignet, um M. ochracea in in vitro-, Gewächshaus-, Feld- und Litterbagversuchen nachzuweisen.

In Gewächshausuntersuchungen konnte der Anteil infektiöser Mikrosklerotien im Boden durch eine Granulatinokulation mit dem Produkt M. ochracea WG (8,3 bzw. 1,7 x $10^{7}$ Sporen/g Boden) reduziert werden, was sich in einem geringeren Befall von Rapspflanzen mit $V$. longisporum äußerte. Die Befallsstärke von $V$. longisporum sank dabei mit steigender Inokulumdichte von M. ochracea WG. Durch eine Gießapplikation

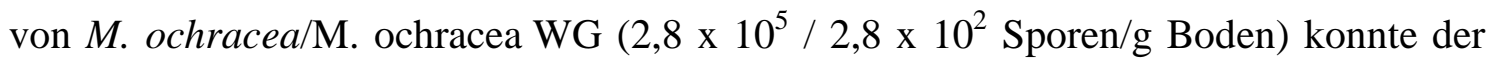
Rapspflanzenbefall durch den Erreger V. longisporum nicht verringert werden. Daraus lässt sich schließen, dass der Anteil infektiöser Mikrosklerotien im Boden nicht reduziert wurde. Somit hatte die Inokulumdichte von M. ochracea im Boden einen wesentlichen Einfluss auf den biologischen Bekämpfungserfolg gegenüber $V$. longisporum.

In den Jahren 2007 bis 2009 wurden Feldversuche mit Winterraps und Winterweizen angelegt. In den Versuchen fanden Behandlungen von Boden und Ernterückständen mit 1 bzw. 2 kg/ha M. ochracea WG im Herbst bzw. Herbst und Frühjahr statt.

Im Monokulturversuch mit Winterweizen konnte das Inokulum von M. graminicola und P. tritici-repentis reduziert werden. Dies äußerte sich in einem reduzierten Blattbefall mit Septoria tritici und Drechslera tritici-repentis.

Im Monokulturversuch mit Winterraps wurde in beiden Versuchsjahren ein geringerer Befall der Rapspflanzen mit P. lingam in den mit M. ochracea WG behandelten Varianten bonitiert. Durch eine Erhöhung der Aufwandmenge und durch Doppelbehandlungen stellten sich dabei bessere Bekämpfungserfolge ein. Der Befall der Rapspflanzen mit $V$. longisporum konnte durch eine Behandlung mit M. ochracea WG weder 2008 noch 2009 reduziert werden. In den Feldversuchen konnte somit kein Abbau der Mikrosklerotien durch M. ochracea nachgewiesen werden.

Des Weiteren fanden unter kontrollierten Bedingungen und in Litterbagversuchen im Freiland, Untersuchungen über den Abbau des Inokulums von V. longisporum durch M. ochracea statt. In sterilem Sand besiedelte der Antagonist sterile Rapsstängel, die 
mit Mikrosklerotien bewachsenen waren und reduzierte das Inokulum von V. longisporum. Weder unter kontrollierten Bedingungen, noch in den Litterbagversuchen konnte ein Inokulumabbau von $V$. longisporum durch $M$. ochracea auf unsterilen Rapsstängeln in unsterilem Boden nachgewiesen werden. Auch kam es zu keiner Besiedlung der Rapsstängel mit M. ochracea in unsterilem Boden. Im Gegensatz dazu wurde durch Inokulation befallsfreier Rapsstängel mit M. ochracea und Inkubation auf der Bodenoberfläche eine Besiedlung der Rapsstängel mit M. ochracea nachgewiesen.

In weiteren Untersuchungen wurde ein negativer Einfluss der Bodenfungistasis auf die Sporenkeimung von $M$. ochracea ermittelt. Durch Zugabe von Glukose oder Sterilisation der Böden wurde die Bodenfungistasis überwunden und die Sporen zur Keimung angeregt.

Zusammenfassend zeigen die vorgestellten Ergebnisse, dass M. ochracea ein sehr großes antagonistisches Potential unter sterilen Bedingungen entfalten kann. Dabei sind die Konkurrenz um Nährstoffe und Raum bei der Antagonist-Pathogen Interaktion von großer Bedeutung. Aufgrund der unzureichenden Wirkungserfolge in den Feldversuchen wird sich M. ochracea nicht als Wirkorganismus eines biologischen Pflanzenschutzmittels zum Einsatz im Getreide- und Rapsanbau behaupten können. 


\section{Abstract}

This work deals with the degradation of the inoculum of straw- and soilborne phytopathogenic fungi, during crop and rapeseed production, by the fungal antagonist Microsphaeropsis ochracea. The aim was to answer the question, if this organism can be used as the basis of a new biological plant protection product. The emphasis was placed on a possible degradation of inoculum of the soilborne phytopathogenic fungi Verticillium longisporum on rape stem. To this interaction studies in in vitro-, Greenhouse-, Litterbag- and field trials have been made. Additional field trials should clarify whether treatment of plant residues from winter rape and winter wheat with M. ochracea can diminish the inoculum production of Mycosphaerella graminicola, Pyrenophora tritici-repentis and Leptosphaeria maculans, and therefore reduce the infestation of cultivated plants.

An in vitro culture test has been developed for interaction studies between $M$. ochracea and Verticillium spp.. This test was shown to be suitable to investigate the effect of M. ochracea on germination of microsclerotia of Verticillium spp. in dependence of different environmental factors. M. ochracea was shown to strongly inhibit germination of microsclerotia of $\mathrm{V}$. longisporum over a broad temperature range $\left(4^{\circ} \mathrm{C}\right.$ to $\left.24^{\circ} \mathrm{C}\right)$. The antagonistic level of efficiency of $M$. ochracea on microsclerotia of $V$. longisporum could be enhanced by increasing the inoculum density of $M$. ochracea and the elongation of the incubation period. Further investigations demonstrated that formation of pycnidia of $M$. ochracea on rape stem and culture medium is promoted by light. However, light had no influence on the antagonistic effect of $M$. ochracea on microsclerotia of $V$. longisporum. Beside environmental factors, the Verticillium species had influence on pest control results. Germination of microsclerotia of V. longisporum was inhibited stronger by $M$. ochracea than germination of microsklerotia of $V$. dahliae. Interaction studies between $M$. ochracea and $V$. longisporum on sterile rape stems showed that inoculation with M. ochracea can inhibit formation of microsclerotia of V. longisporum.

A PCR-based method for sensitive detection of $M$. ochracea has been established. Primers have been designed on the basis of the rDNA sequence of the „Internal Transcribed Spacer“ (ITS) region of $M$. ochracea. These primers have been shown to be 
suitable for the detection of M. ochracea in in vitro-, greenhouse-, litterbag- and field trials.

In Greenhouse trials the fraction of infectious microsclerotia in soil could be reduced by granulate inoculation with the product M. ochracea WG (8,3 bzw. 1,7 x $10^{7}$ spore/g soil), manifested in a lesser infestation of rape plants by $V$. longisporum. With increasing inoculum density of $\mathrm{M}$. ochracea WG the infection level of $V$. longisporum was reduced. The infestation of rape plants by $V$. longisporum could not be reduced by use of curtain application with M. ochracea/M. ochracea WG $\left(2,8 \times 10^{5} / 2,8 \times 10^{2}\right.$ spore/g soil). This leads to the conclusion that the fraction of infectious microsclerotia in soil could not be reduced. Therefore the inoculum density of $M$. ochracea in soil had a considerable effect on the biological pest control results against $V$. longisporum.

From 2007 until 2009 field trials with winter oilseed rape and winter wheat have been layed out. Soil and plant residues have been treated with 1 or $2 \mathrm{~kg} / \mathrm{ha}$ M. ochracea WG in autumn or autumn and spring respectively. The inoculum of M. graminicola and P. tritici-repentis could be reduced in a monoculture experiment with winter wheat. This was manifested by a reduced infestation of the leafes with Septoria tritici and Drechslera tritici-repentis.

In monoculture experiments with winter rape a lesser infestation with $P$. lingam of rape plants treated with M. ochracea WG compared to untreated plants could be observed visually in both trial years. Better pest control results could be achieved by increasing the application rate and by treating twice. The infestation of rape plants with V. longisporum could not be reduced by treatment with M. ochracea WG neither 2008 nor 2009. Hence no degradation of microsclerotia by $M$. ochracea could be demonstrated in the field trials.

Furthermore investigations of the degradation of the inoculum of $V$. longisporum by M. ochracea took place under controlled conditions and in litterbag trials in the field. In sterile sand the antagonist settled on sterile rape stems, overgrown by microsclerotia and reduced the inoculum of $V$. longisporum. No degradation of microsclerotia of $V$. longisporum by $M$. ochracea could be demonstrated on unsterile rape stems in unsterile soil, neither under controlled conditions nor in the litterbag trials. The rape stems were not settled by $M$. ochracea in unsterile soil. In contrast to this, the inoculation with M. ochracea of rape stems, free of infestation, lead to a settlement by $M$. ochracea after 
incubation on soil. Further investigations revealed a negative influence of soil fungistasis on the spore germination of $M$. ochracea. The soil fungistasis could be overcome and spore germination was stimulated by addition of glucose or sterilisation of the soil.

In conclusion the presented results show that M. ochracea can develop a great antagonistic potential under sterile conditions. Thereby the competition for nutrients and space between antagonist and pathogen is very important. Due to insufficient pest control results in the field trials $M$. ochracea will not be able to hold its own as the basis of a biological plant protection product for the application in cultivation of cereal and rape. 


\section{Literaturverzeichnis}

Adams, P. B. 1990: The potential of mycoparasites for biological control of plant diseases. Annu. Rev. Phytopathol. 28, 59-72.

Alabouvette, C., C. Olivain, C. Steinberg, 2006: Biological control of plant diseases: the European situation. European Journal of Plant Pathology. 114, 329-341.

Ashworth, L. J., O. C. Huisman, D. M. Harper, L. K. Stromberg, 1979: Verticillium wilt disease of Tomato: Influence of Inoculum density and root extension upon disease severity. Phytopathology. 69, 490-492.

Atkins, S. D, I. M. Clark, 2004: Fungal molecular diagnostics: a mini review. J. App. Genet. 45, 3-15.

Balgheim, R., 2006: Herbizidresistenz vermeiden, Wirkstoffe erhalten-eine Gemeinschaftsaufgabe von Beratung, Forschung und Praxis am Beispiel des Ackerfuchsschwanz (Alopecurus myosuroides Huds.). Zeitschrift für Pflanzenkrankheiten und Pflanzenschutz, Sonderheft. XX, 49-56.

Bartels, G., B. Broschewitz, J., Frahm, V. Grabe, C. von Kröcher, H. Mielke, R. Saur, C. Schmidt, U. Steck, 2000: Eppo- Richtlinie PP 1/26(3) Blattkrankheiten an Getreide. Herausgegeben von der Biologischen Bundesanstalt für Land- und Forstwirtschaft Bundesrepublik Deutschland.

Bassam, S. E., N. Benhamou, O. Carisse, 2002: The role of melanin in the antagonistic interaction between the apple scab pathogen Venturia inaequalis and Microsphaeropsis ochracea. Canadian Journal of Microbiology, 48, 349-358.

Beer, E., 2005: Arbeitsergebnisse aus der Projektgruppe „Krankheiten im Getreide“ der Deutschen Phytomedizinischen Gesellschaft e.V. Gesunde Pflanze. 57, 59-70.

Benett, A. J., C. Leifert, J. M. Whipps, 2003: Survival of the biocontrol agents Coniothyrium minitans and Bacillus subtilis MBI 600 introduced into pasteurised, sterilised and non-sterile soils. Soil Biology \& Biochemistry. 35, 1565-1573.

Benett, A. J., C. Leifert, J. M. Whipps, 2005: Effect of combined treatment of pasteurisation and Coniothyrium minitans on sclerotia of Sclerotinia sclerotiorum in soil. European Journal of Plant Pathology. 113, 197-209.

Benett, A. J., C. Leifert, J. M. Whipps, 2006: Survival of Coniothyrium minitans associated with sclerotia of Sclerotinia sclerotiorum in soil. Soil Biology \& Biochemistry. 38, 164-172.

Benyagoub, M., N. Benhamou, O. Carisse, 1998: Cytochemical investigation of the antagonistic interaction between a Microsphaeropsis sp. (Isolate P130A) and Venturia inaequalis. Phytopathology. 88, 605-613. 
Berg, G., C. Zachow, J. Lottmann, M. Götz, R. Costa, K. Smalla, 2005: Impact of plant species and site on rhizosphere-associated fungi antagonistic to Verticillium dahliae Kleb. Applied and Enviromental Microbiology, 71, 4203-4213.

Bernier, J., O. Carisse, T. C. Paulitz, 1996: Fungal communities isolated from dead apple leaves from ochrads in Quebec. Phytoprotection. 77, 129-134.

Bhat, R. G., K. V. Subbarao, 1999: Host range specificity in Verticillium dahliae. Phytopathology. 89, 1218-1225.

Blum, U., T. M. Gerig, A. D. Worsham, L. D. King, 1993: Modification of allelopathic effects of p-coumaric acid on morning-glory seedlings biomass by glucose, methionine, and nitrate. Journal of chemical ecology. 19, 2791-2811.

Brandes, H. unveröffentlicht, 2008: Untersuchungen zur Parasitierung der Sklerotien von Sclerotinia sclerotiorum durch die Mycoparasiten Coniothyrium minitans und Microsphaeropsis ochracea. Bachelorarbeit im Department für Nutzpflanzenwissenschaften, Allgemeine Pflanzenpathologie und Pflanzenschutz der Georg August Universität Göttingen.

Brandfaß, C. \& P. Karlovsky, 2006: Simultaneous detection of Fusarium culmorum and F. graminearum in plant material by duplex PCR with melting curve analysis. BMC Microbiology. 6,4.

Bristow, P. R. \& J. L. Lockwood, 1975: Soil fungistasis: Role of the microbial nutrient sink and of fungistatic substances in two soils. Journal of General Microbiology. 90, 147-156.

Budge, S. P. \& J. M. Whipps, 1991: Glasshouse trials of Coniothyrium minitans and Trichoderma species for the biological control of Sclerotinia sclerotiorum in celery and lettuce. Plant Pathology. 40, 59-66.

Bujold, I., T. C. Paulitz, O. Carisse, 2001: Effect of Microsphaeropsis sp. on the production of perithecia and ascospores of Gibberella zeae. Plant Disease. 85, 977-984.

Bundesministerium für Verbraucherschutz, Ernährung und Landwirtschaft (BMVEL): Reduktionsprogramm chemischer Pflanzenschutz: Nachhaltige Landwirtschaft vorsorgender Verbraucherschutz - Schutz des Naturhaushaltes. Bundesministerium für Verbraucherschutz, Ernährung und Landwirtschaft, 11055 Berlin.

Bundesministerium für Ernährung, Landwirtschaft und Verbraucherschutz (BMELV), 2008: Nationaler Aktionsplan zur nachhaltigen Anwendung von Pflanzenschutzmitteln: Risikominderung im Pflanzenschutz weniger Kosten mehr Vertrauen. BMELV, 53123 Bonn.

Bundessortenamt 2008: Beschreibende Sortenliste Getreide, Mais, Ölfrüchte, Leguminosen und Hackfrüchte. Bundessortenamt Hannover. 
Carisse, O., V. Philion, D. Rolland, J. Bernier, 2000: Effect of fall application of fungal antagonists on spring ascospore production of the apple scab pathogen Venturia inaequalis. Phytopathology. 90, 31-37.

Carisse, O. \& J. Bernier, 2002a: Effect of enviromental factors on growth, pycnidial production and spore germination of Microsphaeropsis isolates with biocontrol potential against apple scab. Mycol. Res. 106, 1455-1462.

Carisse, O., S. E. Bassam, N. Bhamou, 2001: Effect of Micosphaeropsis sp. strain P130A on germination and production os sclerotia of Rhizoctonia solani and interaction between the antagonist and the pathogen. Phytopathology. 91, 782791.

Carisse O., 2001: Effect of Microsphaeropsis ochracea, a new biocontrol agent, on germination of sclerotia of Sclerotinia sclerotiorum. Abstracts from the $11^{\text {th }}$ international sclerotinia workshop, 53-54. http://www.bspp.org.uk/archives/ sclerotinia2001/index.php.

Carisse, O. \& J. Bernier, 2002b: Microsphaeropsis ochracea sp. Nov. associated with dead apple leaves. Mycologia 94, 297-301.

Carisse, O. \& D Rolland, 2004: Effect of timing of application of the biological control agent Microsphaeropsis ochracea on the production and ejection pattern of ascospores by Venturia inaequalis. Phytopathology. 94, 1305-1314.

Carisse, O., D. Rolland, D. M. Tremblay, 2006: Effect of Microsphaeropsis ochracea on production of sclerotia-borne and airborne conidia of Botrytis squamosa. BioControl. 51, 107-126.

Datnoff, L. E., S. Nemec, K. Pernezny, 1995: Biological control of Fusarium crown and root rot of tomato in Florida using Trichoderma harzianum and Glomus intraradices. Biological Control. 5, 427-431.

Danielsson, J., O. Reva, J. Meijer, 2007: Protection of oilseed rape (Brassica napus) toward fungal pathogens by strains of plant-associated Bacillus amyloliquefaciens. Microbial Ecology. 54, 134-140.

Debode, J., K. De Maeyer, M. Perneel, J. Pannecoucque, G. De Backer, M. Höfte, 2007: Biosurfactants are involved in the biological control of Verticillium microsclerotia by Pseudomonas spp.. Journal of Applied Microbiology ISSN 1364-5072.

De Boer, W., P. Verheggen, P. J. A. Klein Gunnewiek, G. A. Kowalchuk, J. A. van Veen, 2003: Microbial community composition affects soil fungistasis. Applied and Enviromental Microbiology. 69, 835-844.

Demeke, T. \& R. P. Adams, 1992: The effects of plant polysaccharides and buffer additives on PCR. Biotechniques. 12, 332-334.

Dix, N. J., 1972: Effect of soil fungistasis on spore germination and germtube growth in Penicillium species. Trans. Br. Mycol. Soc. 58, 59-66. 
Dobbs, C. G. \& W. H. Hinson, 1953: A widespread fungistasis in soils. Nature. 172, 197-199

Dobbs, C. G. \& M. J. Gash, 1965: Microbial and residual mycostasis in soils. Nature. 207, 1354-1356.

El-Sayed, M. Embaby, 2006: Using a biofungicide (Coniothyrium minitans Campbell.) in controlling some soilborne plant pathogenic fungi in egypt. Research Journal of Agriculture and Biological Sciences. 2, 423-432.

Eynck, C., B. Koopmann, G. Grunewaldt-Stoecker, P. Karlovsky, A. von Tiedemann 2007: Differential interactions of Verticillium longisporum and V. dahliae with Brassica napus detected with molecular and histological techniques. Eururopean Journal of Plant Pathology. 118, 259-274.

Eynck, C., 2007: Identification of resistance sources and characterization of resistance factors in Brassica species to Verticillium longisporum. Dissertation, Universität Göttingen.

Faggian, R., S. R. Bulmann, A. C. Lawrie, I. J. Porter, 1999: Specific polymerase chain reaction primers for the detection of Plasmodiophora brassicae in soil and water. Phytopathology. 89, 392-397.

Fahima, T., L. Madi, Y. Henis, 1992: Ultrastructure and germinability of Verticillium dahliae microsclerotia parasitized by Talaromyces flavus on agar medium and in treated soil. Biocontrol Science and Technology. 2, 69-78.

Farley, J. D., S. Wilhelm, W. C. Snyder, 1971: Repeated germination and sporulation of microsclerotia of Verticillium albo-atrum in soil. Phytopathology. 61, 260-264.

Feldstein, F. G., B. Jaser, 2008: Fungizidresistenz: Aktueller Stand der Erhebungen im Getreide und Interpretation der Ergebnisse. Aus: Nachrichtenblatt des Deutschen Pflanzenschutzdienstes. 60, 39

Fokkema, N. J., 1973: The role of saprophytic fungi in antagonism against Drechslera sorokiniana (Helminthosporium sativum) on agar plates and on rye leaves with pollen. Physiological Plant Pathology. 3, 195-205.

Fravel, D. R., 1988: Role of antibiosis in the biocontrol of plant disease. Ann. Rev. Phytopathol. 26, 75-91.

Fravel, D. R., 2005: Commercialization and implementation of biocontrol. Annu. Rev. Phytopathol. 43, 337-359.

Freeman, S., D. Minz, I. Kolenski, O. Barbul, A. Zveibil, M. Maymon, Y. Nitzani, B. Kirshner, D. Rav-David, A. Bilu, A. Dag, S. Shafir, Y. Elad, 2004: Trichoderma biocontrol of Colletotrichum acutatum and Botrytis cinera and survival in strawberry. Europen Journal of Plant Pathology. 110, 361-370 
Gerlagh, M., M. Kruse, H. M. van de Geijn, J. M. Whipps, 1994: Growth and survival of the mycoparasite Coniothyrium minitans on lettuce leaves in contact with soil in the presence or absence of Sclerotinia sclerotiorum. European Journal of Plant Pathology. 100, 55-59.

Gerlagh, M., J. M Whipps, S. P. Budge, H. M. Goossen-van de Geijn, 1996: Efficiency of isolates of Coniothyrium minitans as mycoparasites of Sclerotinia sclerotiorum, Sclerotium cepivorum and Botrytis cinera on tomato stem pieces. European Journal of Plant Pathology. 102, 787-793.

Gerlagh, M., H. M. Goossen van de Geijn, N. J. Fokkema, P. F. G. Vereijken, 1999: Long-Term biosanitation by application of Coniothyrium minitans on Sclerotinia sclerotiorum infected crops. Phytopathology. 89, 2, 141-147.

Gilbert, J. \& W. G. D. Fernando, 2004: Epidemiology and biological control of Gibberella zeae / Fusarium graminearum. Can. J. Plant Pathol. 26, 464-472.

Goldstein, A. I., M. A. Carpenter, R. N. Crowhurst, A. Stewart, 2000: Identification of Coniothyrium minitans isolates using PCR amplification of a dispersed repetitive element. Mycologia. 92, 46-53.

Grendene, A., P. Minardi, A. Giacomini, A. Squartini, P. Mrciano, 2002: Characterization of the mycoparasite Coniothyrium minitans: comparison between morpho-physiological and molecular analyses. Mycol. Res. 106, 796-807.

Handelsman, J. \& E. v. Stabb, 1996: Biocontrol of soilborne plant pathogens. The Plant Cell. 8, 1855-1869.

Henson, J. M., T. Goins, W. Grey, D. E. Mathre, M. L. Elliott, 1993: Use of Polymerase Chain Reaction to detect Gaeumannomycea graminis DNA in plants grown in artificially and naturally infested soil. Phytopathology. 83, 283-287.

Heppner, C., 1995: Nachweis von Verticillium dahliae Kleb. im Boden mit Plattengussverfahren und ELISA (enzyme- linked immunosorbent assay) sowie Untersuchungen zur Auswirkung des Inokulums auf den Befall von Winterraps (Brassica napus ssp. olifera Metzg.). Dissertation Universität Göttingen, Cuvillier Verlag, Göttingen.

Hoppes, B. C. \& W. R. McClure, 1981: Studies on the selectivity of DNA precipitation by spermine. Nucleic Acids Research. 9, 5493-5504.

Hora, T. S. \& R. Baker, 1972: Soil Fungistasis: Microflora producing a volatile inhibitor. Trans. Br. Mycol. Soc. 59, 491-500.

Hora, T. S., R. Baker, G. J. Griffin, 1977: Experimental evaluation of hypotheses explaining the nature of soil fungistasis. Phytopathology. 67, 373-379.

Howel, C. R., 2003: Mechanism employed by Trichoderma species in the biological control of plant disease: the history and evolution of current concepts. Plant Disease. 87, 4-10. 
Industrieverband Agrar e.V., 2009: Integrierter Pflanzenschutz. Herausgeber: Industrieverband Agrar e.V. 60329 Frankfuhrt am Main.

Jilani, G., S. Mahmood, A. N. Chaudhry, I. Hassan, M. Akram, 2008: Allelochemicals: sources, toxicity and microbial transformation in soil -areview. Annals of Microbiology. 58, 351-357.

Jones, D., 1970: Ultrastructure and composition of the cell walls of Sclerotinia sclerotiorum. Trans. Br. Mycol. Soc. 54, 351-360.

Jones D., A. H. Gordon, J. S. D. Bacon, 1973: Co-operative action by endo- and exo- $\beta$ (1-3)-glucanases from parasitic fungi in the degradation of cell-wall glucans of Sclerotinia sclerotiorum (Lib.) de Bary. Biochem. Journal. 140, 47-55.

Jones E. E., A. Stewart, 2000: Selection of mycoparasites of sclerotia of Sclerotinia sclerotiorum isolated from New Zealand soils. New Zealand Journal of Crop and Horticultural Science. 28, 105-114.

Jones, E. E., J. M. Whipps, 2002: Effect of inoculum rates and sources of Coniothyrium minitans on control of Sclerotinia sclerotiorum disease in glasshouse lettuce. European Journal of Plant Pathology. 108, 527-538.

Jones, E. E., A. Mead, J. M. Whipps, 2004: Effect of inoculum type and timing of application of Coniothyrium minitans on Sclerotinia sclerotiorum: Control of sclerotinia disease in glasshouse lettuce. Plant Pathology. 53, 611-620.

Kaur, J., G. D. Munshi, R., S., Singh, E. Koch, 2005: Effect of carbon source on production of lytic enzymes by the sclerotial parasites Trichoderma atroviride and Coniothyrium minitans. J. Phytopathology. 153, 274-279.

Keunecke, H., 2009: Einfluss von Kohlfliegenbefall auf die Infektion und Schadwirkung von Verticillium longisporum und Phoma lingam an Raps. Dissertation Universität Göttingen.

Kieser, T., 1984: Factores affecting the isolation of CCC DNA from Streptomyces lividans and Escherichia coli. Plasmid. 12, 19-36.

Kleiner, A., K. Eichel, 2009: EP verabschiedet neue EU-Pestizidpolitik. Pressemitteilung Pressedienst, 20090112IPR45936.

Ko, W. H. \& F. K. Hora, 1972: Identification of an Al ion as a soil fungitoxin. Soil Science. 113, 42-45.

Kreader, C. A., 1996: Relief of amplification inhibition in PCR with bovine serum albumin or T4 gene 32 protein. Applied and Enviromental Microbiology. 62, 1102-1106.

Kredics, L., Z. Antal, L. Manczinger, A. Szekeres, F. Kevei, E. Nagy, 2003: Influence of enviromental parameters on Trichoderma strains with biocontrol potential. Food Technol. Biotechnol. 41, 37-42. 
Krsek, M., E. M. H. Wellington, 1999: Comparison of different methodes for the isolation and purification of total community DNA from soil. Journal of Microbiological Methodes. 39, 1-16.

Krüger, W., 1982: Die Wurzelhals- und Stängelfäule des Rapses, verursacht durch Phoma lingam (Leptosphaeria maculans), eine schwer bekämpfbare Krankheit. Z. Pflanzenkrankh. Pflanzenschutz. 89, 489-507.

Knudsen, I. M. B., J. Hockenhull, D. F. Jensen, 1995: Biocontrol of seedling disease of barley and wheat caused by Fusarium culmorum and Bipolaris sorokiniana: effects of selected fungal antagonists on growth and yield components. Plant Pathology. 44, 467-477.

Laermann, H.T., 1972: Die Wirkung von Terbutryn und Methabenzthiazuron auf Wintergerste in Abhängigkeit von verschiedenen Bodeneigenschaften und Umweltbedingungen. Dissertation, Universität Göttingen.

Lee, M. W., H. S. Shin, H. J. Choi, 1985: Spore germination of some fungi under different soil conditions in relation to fungistasis. Kor. J. Mycol. 13, 195-201.

Landesamt für Umwelt Landwirtschaft und Geologie Sachsen, 2009: Infodienst Landwirtschaft. 3/2009.

Larena, I., O. Salazar, V. Gzalez, M. C. Julian, V. Rubio, 1999: Design of a primer for ribosomal DNA internal transcribed spacer with enhanced specificity for ascomycetes. Journal of Biotechnology. 75, 187-194.

Larena, I., P. Sabuquillo, P. Melgarejo, A. D. Cal, 2003: Biocontrol of Fusarium and Verticillium wilt of tomato by Penicillium oxalicum under greenhouse and field conditions. Journal of Phytopathology. 151, 507-512.

Larkin, R. P. \& D. R. Fravel, 2002: Effect of varying enviromental conditions on biological control of Fusarium wilt of tomato by nonpathogenic Fusarium spp.. Phytopathology. 92, 1160-1166.

Mathre, D. E., R. J. Cook, N. W. Callan, 1999: From discovery to use. Traversing the world of commercializing biocontrol agents for plant disease control. Plant Disease. 83, 972-983.

Mehl, A., K. Stenzel, 2008: Resistenzmanagement zur Erhaltung der Wirksamkeit von Pflanzenschutzmitteln in der Praxis- am Beispiel der Fungizide. In: Pflanzenproduktion im Wandel-Wandel im Pflanzenschutz, ISBN 978-3-94126100-6.

McQuilken, M. P., S. J. Mitchell, S. P. Budge, J. M. Whipps, J. S. Fenlon, S. A. Archer (1995): Effect of Coniothyrium minitans on sclerotial survival and aphothecial production of Sclerotinia sclerotiorum in field-grown oilseed rape. Plant Pathology. 44, 883-896.

McQuilken, M. P., S. P. Budge, J. M. Whipps, 1997: Effects of culture media and enviromental factors on conidial germination, pycnidial production and hyphal extension of Coniothyrium minitans. Mycol. Res, 101, 11-17. 
Monteiro, L., D. Bonnemaison, A. Vekris, K. G. Petry, J. Bonnet, R. Vidal, J. Cabrita, F. Megraud, 1997: Complex polysaccharides as PCR inhibitors in feces: Helicobacter pylori Model. Journal of Clinical Microbiology. 35, 995-998.

Montesinos, E., 2003: Development, registrtion and commercialization of microbial pesticides for plant protection. Int. Microbiology. 6, 245-252.

Morgen-Jones, G., 1974: Concerning some species of Microsphaeropsis. Canadian Journal of Botany. 52, 2575-2579.

Morgan-Jones, G., J. F. White, 1987: Notes on Coelomycetes. III. Concerning Microsphaeropsis concentrica: Morphology and ultrastructure. Mycotaxon. 30, 177-188.

Muthumeenakshi, S., S. Sreenivasaprasad, C. W. Rogers, M. P. Challen, J. M. Whipps, 2007: Analysis of cDNA transcripts from Coniothyrium minitans reveals a diverse array of genes involved in key processes during sclerotial mycoparasitism. Fungal Genetics and Biology. 44, 1262-1284.

Müller, H., P. Meincke, G. Berg, 2004: Strategy to control Verticillium dahliae in oilseed rape using Serratia plymuthica HRO-C48. IOBC/wprs Bulletin. 27, 161164.

Müller, H., \& G. Berg, 2008: Impact of formulation procedures on the effect of the biocontrol agent Serratia plymuthica HRO-C48 on Verticillium wilt in oilseed rape. BioControl. 53, 905-916.

Papavizas, G. C., 1985: Trichoderma and Gliocladium: Biology, Ecology, and potential for biocontrol. Annual Review of Phytopathology. 23, 23-54.

Partridge, D. E., T. B. Sutton, D. L. Jordan, V. L. Curtis, J. E., Bailey, 2006: Management of sclerotinia blight of Peanut with the biological control agent Coniothyrium minitans. Plant Disease. 90, 957-963.

Perello, A. E., C. I. Monaco, M. V. Moreno, C. A. Cordo, M. R. Simon, 2006: The effect of Trichoderma harzianum and T. koningii on the control of tan spot (Pyrenophora tritici-repentis) and leaf blotch (Mycosphaerella graminicola) of wheat under field conditions in Argentina. Biocontrol Science and Technology. 16, 803-813.

Perello, A. E., M. V. Moreno, C. Monaco, M. R. Simon, C. Cordo, 2009: Biological control of Septoria tritici blotch on wheat by Trichoderma spp. under field conditions in Argentina. Biocontrol. 54, 113-122.

Pfender, W. F., 1988: Suppression of ascocarp formation in Pyrenophora tritici-repentis by Limonomyces roseipellis, a basidiomycete from reduced-tillage wheat straw. Phytopathology. 78, 1254-1258.

Pfender W. F., W. Zhang, A. Nus, 1993: Biological control to reduce inokulum of the Tan Spot Pathogen Pyrenophora trici-repentis in surface-borne residues of wheat fields. Phytopathology. 83, 371-375. 
Phillips, A. J., L., K. Price, 1983: Structural aspects of parasitism of sclerotia of Sclerotinia sclerotiorum (Lib.) de Bary by Coniothyrium minitans Camp. Journal of Phytopathology. 107, 193-203.

Poppe, L., S. Vanhoutte, M. Höfte, 2003: Modes of action of Pantoea agglomerans CPA-2, an antagonist of postharvest pathogens on fruits. European Journal of Plant Pathology. 109, 963-973.

Prophyta Gmbh: Contans ${ }^{\circledR W G ~ B i o l o g i s c h e s ~ F u n g i z i d ~ z u r ~ B e k a ̈ m p f u n g ~ v o n ~ S c l e r o t i n i a ~}$ sclerotiorum an Winterraps, Sonnenblume, Salat, Tabak, Kartoffeln und anderen anfälligen Ackerbau-, Gemüse- und Zierpflanzenkulturen. http://www.belchim. com/pdf/Ger/2009/ contans.pdf

Pullman, G. S. \& J. E. DeVay, 1982: Epidemiology of Verticillium wilt of cotton: A relationship between inoculum density and disease progression. Phytopathology. 72, 549-554.

Reich, J. \& J. Wurlitzer: Pfluglose Bodenbearbeitung in Thüringen auf dem Vormarsch. Thüringer Landesanstalt für Landwirtschaft. http://www.tll.de/ainfo/pdf/ pfll1204.pdf

Ridgway, H. J. \& A. Stewart, 2000: Molecular marker assisted detection of the mycoparasite Coniothyrium minitans A69 in soil. New Zealand Plant Protection. 53, 114-117.

Robb, J., R., Moukhamedov, X. Hu, H. Platt, R. N. Nazar, 1993: Putative subgroups of Verticillium albo-atrum distinguishable by PCR-based assays. Pysiological and Molecular Plant Pathology. 43, 423-436.

Rondon, M. R., R. M. Goodman, J. Handelsman, 1999: The Earth's bounty: assessing and accessing soil micobial diversity. Tibtech. 17, 403-409.

Roux, K. H., 1995: Optimization and troubleshooting in PCR. Genome Res. 4, 185-194.

Schaad, N. W., 1999: Detection of Clavibacter michiganensis subsp. Sepedonicus in potato tubers by Bio-PCR and an automated real-time fluorescence detection system. Plant Disease. 83, 1095-1100.

Schaad, N. W. \& R. D. Frederick, 2002: Real-time PCR and ist application for rapid plant disease diagnostics. Can. J. Plant Pathol. 24, 250-258.

Schaad, N. W., Y. Berthier-Schaad, D. Knorr, 2007: A high throughput membrane BioPCR technique for ultra-sensitive detection of Pseudomonas syringae pv. Phaseolicola. Plant Pathology. 56, 1-8.

Schaafsma, A. W., L. Tamburic-Llincic, D. C. Hooker, 2005: Effect of previous crop, tillage, field size, adjacent crop, and sampling direction on airborne, propagules of Gibberella zeae/Fusarium graminearum, fusarium head blight severity, and deoxinivalenol accumulation in winter wheat. Canadian Journal of Plant Pathology. 27, 217-224. 
Schilling, A. G., E. M. Möller, H. H. Geiger, 1996: Polymerase chain reaction-based assays for species specific detection of Fusarium culmorum, F. graminearum, and F. avenaceum. Phytopathology. 86, 515-522.

Sharma, A. D., P. K. Gill, P Singh, 2002: DNA isolation from dry and fresh samples of polysaccharide-Rich plants. Plant Molecular Biology Reporter. 20, 415a-415f.

Shinners, T. C. \& J. P. Tewari, 2000: Accelerated stubble decomposition using Cyathus olla. Astrategy for control of stubble-borne diseases of canola. Integrated control in oilseed crops IOBC/wprs Bulletin. 23, 77-81.

Smalla, K., N. Cresswell, L. C. Mendonca-Hagler, A. Wolters, J. D. Van Elsas, 1993: Rapid DNA extraction protocol from soil for polymerase cahin reactin-mediated amplification. Journal of Applied Bacteriology. 74, 78-85.

Soesanto, L., A. J. Termorshuizen, 2001: Effect of temperature on formation of microsclerotia of Verticillium dahliae. Journal of Phytopathology. 149, 685-691.

Statistisches Bundesamt, 2008: http://www.destatis.de/jetspeed/portal/cms/Sites/destatis / Internet/DE/Presse/pm/2008/08/PD08_279_412,templateId=renderPrint.psml

Sutton, B. C., 1980: The coelomycetes: Fungi imperfecti with pycnidia, acervuli, and stromata. CABI Publishing, New York.

Tooley, P. W., B. A. Bunyard, M. M. Carras, E. Hatziloukas, 1997: Development of PCR Primers from Internal Transcribed Spacer Region 2 for detection of Phytophtora species infecting potatoes. Applied and Enviromental Microbiology. 63, 1467-1475.

Truttmann, P., P. J. Keane, P. Merriam, 1980: Reduction of sclerotial inoculum of Sclerotinia sclerotiorum with Coniothyrium minitans. Soil Biol. Biochem. 12, 461-465.

Tsai, Y. L. \& B. H. Olson, 1992: Rapid method for separation of bacterial DNA from humic substances in sediments for polymerase chain reaction. Applied and Enviromental Microbiology. 58, 2292-2295.

Turner, G. J. \& H. T. Tribe, 1975: Preliminary field plot trials on biological control of Sclerotinia trifoliorum by Coniothyrium minitans. Plant Pathology, 24, 109-113.

Turner, G. J \& H. T. Tribe, 1976: On Coniothyrium minitans and its parasitism of Sclerotinia species. Trans. Br. Mycol. Soc. 66, 97-105.

von Tiedemann, A., 1993: Zur Schädigung landwirtschaftlicher Nutzpflanzen durch Ozon: Schadsymptome und Einfluß auf pilzliche Blattkrankheiten am Beispiel des Weizens. 1. Auflage, Culliver Verlag, Göttingen.

Yang, R., Y. Han, G. Li, D. Jiang, H. C. Huang, 2008: Effect of ambient pH and nutritional factors on antifungal activity of the mycoparasite Coniothyrium minitans. Biological Control. 44, 116-127. 
Zeise, K., 1992: Gewächshaustest zur Resistenzprüfung von Winterraps (Brassica napus L. var. oleifera Metzger) gegen den Erreger der Rapswelke Verticillium dahliae Kleb. Nachrichtenbl. Deut. Pflanzenschutzd. 44, 125-128.

Ufop, 2009: http://www.ufop.de/3312.php

von Tiedemann, A., K. Hedke, R. Mögling, 2000: Biologische Bekämpfung der Sclerotinia-Weißstängeligkeit. Eine Möglichkeit zur nachhaltigen Pilzbekämpfung im Raps. Raps. 1, 1-4.

von Tiedemann, K. Hedke, R. Mögling, 2001: Abbauverhalten von Sklerotien der Weißstängeligkeit bei Einsatz von Contans. Raps. 1, 1-3.

Vogt, M. \& M. Kirchner, 2006: Hinweise zur pfluglosen Bodenbearbeitung. Landesbetrieb Landwirtschaft Hessen 18.01.2006. http://www.llhhessen.de/landwirtschaft/pflanzenbau/veroeffentlichungen/pfluglosebodenbearbeit ung.pdf

Wafaa, M. E. \& Haggag, 1999: The antagonistic effect of Coniothyrium minitans Campbell, against some sclerotial pathogenic fungi using scanning electron microscopy. Arab. Journal of Biotechnology. 2, 15-26.

Walters, D 2009: Disease control in crops. Biologically and enviromentally friendly approaches. ISBN: 978-1-4051-6947-9.

Watson, A. G. \& E. J. Ford, 172: Soil Fungistasis- A Reappraisal. Annual Review of Phytopathology. 10, 327-346.

Watson, A. K. \& J. E. Miltimore, 1975: Parasitism of sclerotia of Sclerotinia sclerotiorum by Microsphaeropsis centaureae. Canadian Journal of Botany. 53, 2458-2461.

Whipps, J. M., S. K. Grewal, 1991: Interaction between Coniothyrium minitans and sclerotia. Mycol. Res. 95, 295-299.

Whipps, J. M. \& M. Gerlach, 1992: Biology of Coniothyrium minitans and ist potential for use in disease biocontrol. Mycological Research. 96, 897-907.

Whipps, J. M., 2001: Microbial interactions and biocontrol in the rhizosphere. Journal of Experimental Botany. 52, 487-511.

White, T.J., T. Bruns, S. Lee, J. Taylor, 1991: Amplification and direct sequencing of fungal ribosomal RNA genes for phylogenetics. Aus: PCR Protocols, A guide to Methods and Applications. Academic Press ISBN 0123721806.

Williams, P.H. \& C. B. Hill, 1986: Rapid cycling populations of Brassica. Science. 232, 1385-1389.

Wilson, I. G., 1997: Inhibition and Facilitation of Nucleic acid amplification. Applied and Enviromental Microbiology. 63, 3741-3751. 
Yang, L., G. Qing Li, D. Jiang, H. C. Huang, 2009: Water-assisted dissemination of conidia of the mycoparasite Coniothyrium minitans in soil. Biocontrol Science and Technology. 19, 779-796.

Yoder, D. L. \& J. L. Lockwood, 1973: Fungal spore germination on natural and sterile soil. Journal of General Microbiology. 74, 107-117. 


\section{Anhang}

Tab. 1A: Acker und Pflanzenbauliche Maßnahmen im Winterweizenmonokulturvesuch 2007/2008 am Standort „Große Breite“ Göttingen-Weende.

\begin{tabular}{|c|c|c|}
\hline Vorfrucht & 14.07.07 & Ernte Winterweizen \\
\hline Bodenbearbeitung & 20.08 .07 & Väderstatt Carrier \\
\hline M. ochracea Herbstinokulation & 06.09.07 & $\begin{array}{l}\text { Pflanzenschutzspritze M. ochracea } \\
\text { WG } 1 \mathrm{~kg} / \mathrm{ha}, 2 \mathrm{~kg} / \mathrm{ha}\end{array}$ \\
\hline Bodenbearbeitung & 06.09 .07 & Kreiselegge \\
\hline Aussaat & 24.09 .07 & $\begin{array}{l}\text { Hassia Drillmaschine, Paroli } 275 \\
\text { Kö/m2, 92\% KF, 48,2g TKG, Arena C } \\
\text { + Lattitude gebeizt }\end{array}$ \\
\hline M. ochracea Frühjahrsinokulation & 02.04 .08 & $\begin{array}{l}\text { EC 27: Pflanzenschutzspritze M. } \\
\text { ochracea WG } 1 \mathrm{~kg} / \mathrm{ha}, 2 \mathrm{~kg} / \mathrm{ha}\end{array}$ \\
\hline \multicolumn{3}{|l|}{ Pflanzenschutz } \\
\hline Insektizid & 05.11 .07 & 0,2 l/ha Sumicidin alpha \\
\hline Herbizid & 05.11 .07 & $\begin{array}{l}\text { EC 13: 0,45l/ha Axial, 1,35 l/ha FHS, } \\
\text { 1l/ha Fenikan }\end{array}$ \\
\hline Herbizid & 24.04 .08 & EC 31: 0,5 l/ha Tomigan \\
\hline Herbizid & 21.05 .08 & EC 39: 0,25g/ha Pointer \\
\hline Fungizid (Fungizidvariante) & 17.04 .08 & $\begin{array}{l}\text { EC 29: 0,8 l/ha Folicur + 0,8 l/ha } \\
\text { Caramba }\end{array}$ \\
\hline Fungizid (Fungizidvariante) & 21.05 .08 & EC 39: 0,6 1/ha Gladio + 1 l/ha Bravo \\
\hline Wachstumsregler & 01.04 .08 & EC 27: 1,2 l/ha CCC720 \\
\hline Wachstumsregler & 24.04 .08 & $\begin{array}{l}\text { EC 31: 0,5 l/ha CCC720 + 0,2 l/ha } \\
\text { Modus }\end{array}$ \\
\hline \multicolumn{3}{|l|}{ Düngung } \\
\hline N-Düngung & 28.02 .08 & EC 23: $80 \mathrm{~kg}$ N/ha als AHL \\
\hline N-Düngung & 18.04.08 & EC 29: $60 \mathrm{~kg}$ N/ha als AHL \\
\hline N-Düngung & 26.05 .08 & EC 39: $60 \mathrm{~kg}$ N/ha als AHL \\
\hline Krankheitsbonitur & 27.05 .08 & EC 45-51: DTR, Septoria Blattflecken \\
\hline Krankheitsbonitur & 23.06 .08 & EC 75: DTR, Septoria Blattflecken \\
\hline Ernte & 01.08.08 & \\
\hline
\end{tabular}


Tab. 2A: Acker und Pflanzenbauliche Maßnahmen im Winterweizenmonokulturvesuch 2008/2009 am Standort „Große Breite“ Göttingen-Weende

\begin{tabular}{|c|c|c|}
\hline Vorfrucht & 01.08 .08 & Ernte Winterweizen \\
\hline Bodenbearbeitung & 13.08 .08 & Grubber \\
\hline Bodenbearbeitung & 11.09 .08 & Grubber \\
\hline Bodenbearbeitung & 07.08 .08 & Kreiselegge + Walze \\
\hline M. ochracea Herbstinokulation & 15.09 .08 & $\begin{array}{l}\text { Pflanzenschutzspritze M. ochracea } \\
\text { WG } 1 \mathrm{~kg} / \mathrm{ha}, 2 \mathrm{~kg} / \mathrm{ha}\end{array}$ \\
\hline Bodenbearbeitung & 15.09 .08 & Kreiselegge + Walze \\
\hline Aussaat & 15.10 .08 & $\begin{array}{l}\text { Hassia Drillmaschine, Paroli } 330 \\
\text { Kö/m², 92\% KF, 48,2g TKG, Arena C } \\
\text { gebeizt }\end{array}$ \\
\hline M. ochracea Frühjahrsinokulation & 02.04 .09 & $\begin{array}{l}\text { EC: } 23 \text { Pflanzenschutzspritze M. } \\
\text { ochracea WG 1kg/ha, 2kg/ha }\end{array}$ \\
\hline \multicolumn{3}{|l|}{ Pflanzenschutz } \\
\hline Herbizid & 21.10 .08 & $\begin{array}{l}\text { EC 11: } 4 \text { l/ha Malibu, 2,5 l/ha Stomp } \\
\text { SC }\end{array}$ \\
\hline Herbizid & 04.05 .09 & $\begin{array}{l}\text { EC 31/32: 12,5 g/ha Monitor, 0,5 l/ha } \\
\text { Monfast }\end{array}$ \\
\hline Fungizid (Fungizidvariante) & 21.04 .09 & EC 27: 1,5 l/ha Opus Top \\
\hline Fungizid (Fungizidvariante) & 20.05 .09 & $\begin{array}{l}\text { EC 37/39: 0,6 1/ha Champion, 0,6 1/ha } \\
\text { Diamant }\end{array}$ \\
\hline Fungizid (Fungizidvariante) & 09.06 .09 & EC 65: 0,4 l/ha Taspa, 0,5 l/ha Folicur \\
\hline Wachstumsregler & 14.04 .09 & EC 27: 1,3 l/ha CCC720 \\
\hline Wachstumsregler & 07.05 .09 & $\begin{array}{l}\text { EC 31: 0,5 l/ha CCC720 + 0,2 l/ha } \\
\text { Modus }\end{array}$ \\
\hline \multicolumn{3}{|l|}{ Düngung } \\
\hline N-Düngung & 17.03 .09 & EC 21: $80 \mathrm{~kg}$ N/ha als AHL \\
\hline N-Düngung & 16.04 .09 & EC 27: $60 \mathrm{~kg}$ N/ha als AHL \\
\hline N-Düngung & 26.05 .09 & EC 49: $60 \mathrm{~kg}$ N/ha als AHL \\
\hline Krankheitsbonitur & 02.06 .09 & EC 61: DTR, Septoria Blattflecken \\
\hline Krankheitsbonitur & 29.06 .09 & EC 75: DTR, Septoria Blattflecken \\
\hline Ernte & 30.07 .09 & \\
\hline
\end{tabular}


Tab. 3A: Acker und pflanzenbauliche Maßnahmen im Winterrapsmonokulturversuch 2007/2008 am Standort „Große Lage“ Göttingen-Weende“.

\begin{tabular}{|c|c|c|}
\hline Vorfrucht & 17.07.07 & Ernte Winterraps \\
\hline Bodenbearbeitung & 09.08.07 & Spatenrollgegge \\
\hline M. ochracea Herbstinokulation & 20.08.07 & $\begin{array}{l}\text { Pflanzenschutzspritze M. ochracea } \\
\text { WG } 1 \mathrm{~kg} / \mathrm{ha}, 2 \mathrm{~kg} / \mathrm{ha}\end{array}$ \\
\hline Bodenbearbeitung & 20.08 .07 & Kreiselegge \\
\hline Bodenbearbeitung & 26.08 .07 & Kreiselegge + Walze \\
\hline Aussaat & 27.08 .07 & $\begin{array}{l}\text { Hassia Drillmaschine, Trabant } 60 \\
\text { Kö/m², 95\% KF, 4,5g TKG, Premium } \\
\text { DMM gebeizt }\end{array}$ \\
\hline M. ochracea Frühjahrsinokulation & 02.04 .08 & $\begin{array}{l}\text { EC: } 39 \text { Pflanzenschutzspritze M. } \\
\text { ochracea WG 1kg/ha, } 2 \mathrm{~kg} / \mathrm{ha}\end{array}$ \\
\hline \multicolumn{3}{|l|}{ Pflanzenschutz } \\
\hline Herbizid & 29.08 .07 & VA: 1,7 l/ha Brasan, 0,7 l/ha Butisan \\
\hline Schneckenkorn & 30.08 .07 & 6 kg/ha Pro Limax \\
\hline Fungizid (Fungizidvariante) & 16.10 .07 & $\begin{array}{l}\text { EC 16: 0,2 kg/ha Cantus, 0,5 l/ha } \\
\text { Caramba }\end{array}$ \\
\hline Fungizid (Fungizidvariante) & 17.04 .08 & $\begin{array}{l}\text { EC 59: } 0,8 \text { l/ha Folicur, 0,8 l/ha } \\
\text { Champion }\end{array}$ \\
\hline Wachstumsregler & 01.04 .08 & $\begin{array}{l}\text { EC 39: 0,6 l/ha Moddus, 0,3 l/ha } \\
\text { CCC720 }\end{array}$ \\
\hline Insektizid & 01.04 .08 & EC 39: 0,1 l/ha Fastac SC \\
\hline \multicolumn{3}{|l|}{ Düngung } \\
\hline N-Düngung & 25.02 .08 & $\begin{array}{l}\text { EC 18: } 170 \mathrm{~kg} / \mathrm{ha} \text { SSA }(35,7 \mathrm{kgN} / \mathrm{ha} \text {; } \\
40,8 \mathrm{kgS} / \mathrm{ha})\end{array}$ \\
\hline N-Düngung & 28.02 .08 & EC 18: $80 \mathrm{~kg}$ N/ha als AHL \\
\hline N-Düngung & 09.04 .08 & EC 51: $80 \mathrm{~kg}$ N/ha als AHL \\
\hline Krankheitsbonitur & 13.11.07 & EC 18: P. lingam Herbstbonitur \\
\hline Krankheitsbonitur & 24.06 .08 & EC 80: P. lingam Frühjahrsbonitur \\
\hline Krankheitsbonitur & 01.08 .08 & V. longisporum Stoppelbonitur \\
\hline Ernte & 25.07 .08 & $\begin{array}{l}\text { Keine Ertragserfassung wegen Hagel- } \\
\text { schaden }\end{array}$ \\
\hline
\end{tabular}


Tab. 4A: Acker und pflanzenbauliche Maßnahmen im Winterrapsmonokulturversuch 2008/2009 am Standort „Große Lage“ Göttingen-Weende“.

\begin{tabular}{|c|c|c|}
\hline Vorfrucht & 25.07 .08 & Ernte Winterraps \\
\hline Bodenbearbeitung & 25.07 .08 & Spatenrollgegge \\
\hline Bodenbearbeitung & 13.08 .08 & Grubber \\
\hline M. ochracea Herbstinokulation & 18.08.08 & $\begin{array}{l}\text { Pflanzenschutzspritze M. ochracea } \\
\text { WG } 1 \mathrm{~kg} / \mathrm{ha}, 2 \mathrm{~kg} / \mathrm{ha}\end{array}$ \\
\hline Bodenbearbeitung & 18.08 .08 & Kreiselegge + Walze \\
\hline Aussaat & 18.08 .08 & $\begin{array}{l}\text { Hassia Drillmaschine, Trabant } 55 \\
\text { Kö/m², 90\% KF, 4,5g TKG, Premium } \\
\text { DMM gebeizt }\end{array}$ \\
\hline Bodenbearbeitung & 18.08.08 & Walze \\
\hline M. ochracea Frühjahrsinokulation & 02.04 .09 & $\begin{array}{l}\text { EC: } 35 \text { Pflanzenschutzspritze M. } \\
\text { ochracea WG } 1 \mathrm{~kg} / \mathrm{ha}, 2 \mathrm{~kg} / \mathrm{ha}\end{array}$ \\
\hline \multicolumn{3}{|l|}{ Pflanzenschutz } \\
\hline Herbizid & 20.08 .08 & VA: 1,7 l/ha Brasan, 0,7 l/ha Butisan \\
\hline Schneckenkorn & 20.08 .08 & 6 kg/ha Spiess Urania Schneckenkorn \\
\hline Herbizid & 31.03 .09 & $\begin{array}{l}\text { EC 33: 0,35 l/ha Effigo, } 1 \text { l/ha } \\
\text { Fusilade, } 1 \text { l/ha Oleo }\end{array}$ \\
\hline Fungizid (Fungizidvariante) & 06.04 .09 & EC 50: 0,8 l/ha Folicur \\
\hline Fungizid (Fungizidvariante) & 28.04.09 & EC 63: 0,5 kg/ha Cantus \\
\hline Wachstumsregler & 07.04.09 & $\begin{array}{l}\text { EC 50: 0,7 l/ha Moddus, 0,4 l/ha } \\
\text { CCC720 }\end{array}$ \\
\hline Insektizid & 07.04 .08 & EC 50: 0,1 l/ha Fastac super \\
\hline Insektizid & 16.04 .09 & EC 59: 0,3 l/ha Biscaya \\
\hline \multicolumn{3}{|l|}{ Düngung } \\
\hline N-Düngung & 03.03.09 & $\begin{array}{l}\text { EC 18: } 170 \mathrm{~kg} / \mathrm{ha} \text { SSA }(35,7 \mathrm{kgN} / \mathrm{ha} ; \\
40,8 \mathrm{kgS} / \mathrm{ha})\end{array}$ \\
\hline N-Düngung & 17.03 .09 & EC 24: $80 \mathrm{~kg}$ N/ha als AHL \\
\hline N-Düngung & 02.04 .09 & EC 51: $80 \mathrm{~kg}$ N/ha als AHL \\
\hline Krankheitsbonitur & 03.07 .09 & EC 80: P. lingam Frühjahrsbonitur \\
\hline Krankheitsbonitur & 10.08 .09 & V. longisporum Stoppelbonitur \\
\hline Ernte & 29.07.09 & Ertragserfassung \\
\hline
\end{tabular}


Tab. 5A: Acker und pflanzenbauliche Maßnahmen im Winterraps-Winterweizen Fruchtfolgeversuch 2007/2008 am Standort „Große Lage“ Göttingen-Weende.

\begin{tabular}{|c|c|c|}
\hline Vorfrucht & 17.07 .07 & Ernte Winterraps \\
\hline Bodenbearbeitung & 09.08.07 & Spatenrollgegge \\
\hline M. ochracea Herbstinokulation & 06.09.07 & $\begin{array}{l}\text { Pflanzenschutzspritze M. ochracea } \\
\text { WG } 1 \mathrm{~kg} / \mathrm{ha}, 2 \mathrm{~kg} / \mathrm{ha}\end{array}$ \\
\hline Bodenbearbeitung & 06.09 .07 & Kreiselegge + Walze \\
\hline Aussaat & 24.09 .07 & $\begin{array}{l}\text { Hassia Drillmaschine, Paroli } 275 \\
\text { Kö/m², 92\% KF, 48,2g TKG, Arena C } \\
\text { + Lattitude gebeizt }\end{array}$ \\
\hline \multicolumn{3}{|l|}{ Pflanzenschutz } \\
\hline Herbizid & 05.11 .07 & $\begin{array}{l}\text { EC 13: 0,45 l/ha Axial, 1,35 l/ha FHS, } \\
1 \text { l/ha Fenikan }\end{array}$ \\
\hline Insektizid & 05.11 .07 & EC 13: 0,2 l/ha Sumicidin alpha \\
\hline Wachstumsregler & 01.04 .08 & EC 27: 1,2 l/ha CCC720 \\
\hline Wachstumsregler & 24.04 .08 & 0,5 l/ha CCC720, 0,2 l/ha Modus \\
\hline \multicolumn{3}{|l|}{ Düngung } \\
\hline N-Düngung & 28.02 .08 & EC 23: 80 kg N/ha als AHL \\
\hline N-Düngung & 18.04 .08 & EC 29: 60 kg N/ha als AHL \\
\hline N-Düngung & 26.05 .08 & EC 39: 60 kg N/ha als AHL \\
\hline Ernte & 05.08 .08 & Keine Ertragserfassung \\
\hline
\end{tabular}


Tab. 6A: Acker und pflanzenbauliche Maßnahmen im Winterraps-Winterweizen Fruchtfolgeversuch 2008/2009 am Standort „Große Lage“ Göttingen-Weende.

\begin{tabular}{|c|c|c|}
\hline Vorfrucht & 05.08.08 & Winterweizen \\
\hline Bodenbearbeitung & 09.08.08 & Spatenrollgegge \\
\hline Bodenbearbeitung & 13.08.08 & Grubber \\
\hline M. ochracea Herbstinokulation & 18.08.08 & $\begin{array}{l}\text { Pflanzenschutzspritze M. ochracea } \\
\text { WG } 1 \mathrm{~kg} / \mathrm{ha}, 2 \mathrm{~kg} / \mathrm{ha}\end{array}$ \\
\hline Bodenbearbeitung & 18.08.08 & Kreiselegge + Walze \\
\hline Aussaat & 18.08.08 & $\begin{array}{l}\text { Hassia Drillmaschine, Trabant } 55 \\
\text { Kö/m², 90\% KF, 4,5g TKG, Premium } \\
\text { DMM gebeizt }\end{array}$ \\
\hline Bodenbearbeitung & 18.08.08 & Walze \\
\hline M. ochracea Frühjahrsinokulation & 02.04.09 & $\begin{array}{l}\text { EC: } 35 \text { Pflanzenschutzspritze M. } \\
\text { ochracea WG 1kg/ha, 2kg/ha }\end{array}$ \\
\hline \multicolumn{3}{|l|}{ Pflanzenschutz } \\
\hline Herbizid & 20.08.08 & VA: 1,7 l/ha Brasan, 0,7 l/ha Butisan \\
\hline Herbizid & 08.09 .08 & EC 16: 0,5 l/ha Agil S \\
\hline Schneckenkorn & 20.08.08 & 6 kg/ha Spiess Urania Schneckenkorn \\
\hline Fungizid (Fungizidvariante) & 06.04 .09 & EC 50: 0,8 l/ha Folicur \\
\hline Fungizid (Fungizidvariante) & 28.04.09 & EC 63: 0,5 kg/ha Cantus \\
\hline Wachstumsregler & 16.09 .08 & $\begin{array}{l}\text { EC 16: 0,7 l/ha Moddus, 0,4 l/ha } \\
\text { CCC720 }\end{array}$ \\
\hline Wachstumsregler & 07.04 .09 & $\begin{array}{l}\text { EC 50: 0,7 l/ha Moddus, 0,4 l/ha } \\
\text { CCC720 }\end{array}$ \\
\hline Insektizid & 07.04.08 & EC 50: 0,1 l/ha Fastac super \\
\hline Insektizid & 16.04.09 & EC 59: 0,3 1/ha Biscaya \\
\hline \multicolumn{3}{|l|}{ Düngung } \\
\hline N-Düngung & 03.03.09 & $\begin{array}{l}\text { EC 18: } 170 \mathrm{~kg} / \mathrm{ha} \text { SSA }(35,7 \mathrm{kgN} / \mathrm{ha} \text {; } \\
40,8 \mathrm{kgS} / \mathrm{ha})\end{array}$ \\
\hline N-Düngung & 17.03.09 & EC 24: $80 \mathrm{~kg}$ N/ha als AHL \\
\hline N-Düngung & 02.04.09 & EC 51: 80 kg N/ha als AHL \\
\hline Krankheitsbonitur & 02.07 .09 & EC 80: P. lingam Frühjahrsbonitur \\
\hline Krankheitsbonitur & 10.08.09 & V. longisporum Stoppelbonitur \\
\hline Ernte & 29.07.09 & Ertragserfassung \\
\hline
\end{tabular}


1 GGAAGTAAAAGTCGTAACAAGGTTTCCGTAGGTGAACCTGCGGAAG

47 GATCATTATCGATGGCCGCGCCGTGAGCGCCCTAGTGCAGGATCGGC

94 CGGCCACTGACCACACCCTTACTTTACGAGCACCTTTCGTTCTCCTTC

142 GGCGGGGCAACCCGCCGCTGGAACCACATCAAACCTTTTTTGCATCC

189 AGCATTACCTGTTCTGATAAAAAATAATCGTAACAACTTTCAACAAT

236 GGATCTCTTGGCTCTGGCATCGATGAAGAACGCAGCGAAATGCGATA

283 AGTAGTGTGAATTGCAGAATTCAGTGAATCATCGAATCTTTGAACGC

330 ACATTGCGCCCCTTGGTATTCCATGGGGCATGCCTGTTCGAGCGTCA

377 TCTACACCCTCAAGCTCTGCTTGGTGTTGGGCGTCTGTCCCGCCTCGG

425 CGCGCGGACTCGCCCCAAAGGCATTGGCAGCGGTCCACGGCCCCTCT

472 CGCGCAGCACATTGCGCTTCTCGAGGCGGCCCGGCCCGCATCCACGA

519 AGCCCACATTACCGTCTTTGACCTCGGATCAGGTAGGGATACCCGCT

565 GAACTTAAGCATATCAATAAGCGGAGGA

Abb 1A: DNA-Sequenz (5'-3’) der „Internal Transcribed spacer“ Region von M. ochracea mit dem Primern ITS5 und ITS4. 
Tab. 7A: Nukleotidsequenz und amplifizierte Produktgröße der $M$. ochracea Primer M.o 3-F und M. o 4.1-R.

\begin{tabular}{|l|c|c|c|}
\hline Bezeichnung & $\begin{array}{c}\text { Nukleotidsequenz } \\
5^{\prime}-3^{\prime}\end{array}$ & $\begin{array}{c}\text { Länge } \\
(\mathrm{bp})\end{array}$ & $\begin{array}{c}\text { Produktgröße } \\
(\mathrm{bp})\end{array}$ \\
\hline M.o 3-F & CCA CAT CCA AAC TTT TTT GCA TCC & 24 & \multirow{2}{*}{380} \\
\cline { 1 - 3 } M.o 4.1-R & CGA GGT CAA AGA CGG TAA GTGG & 23 & \\
\hline
\end{tabular}

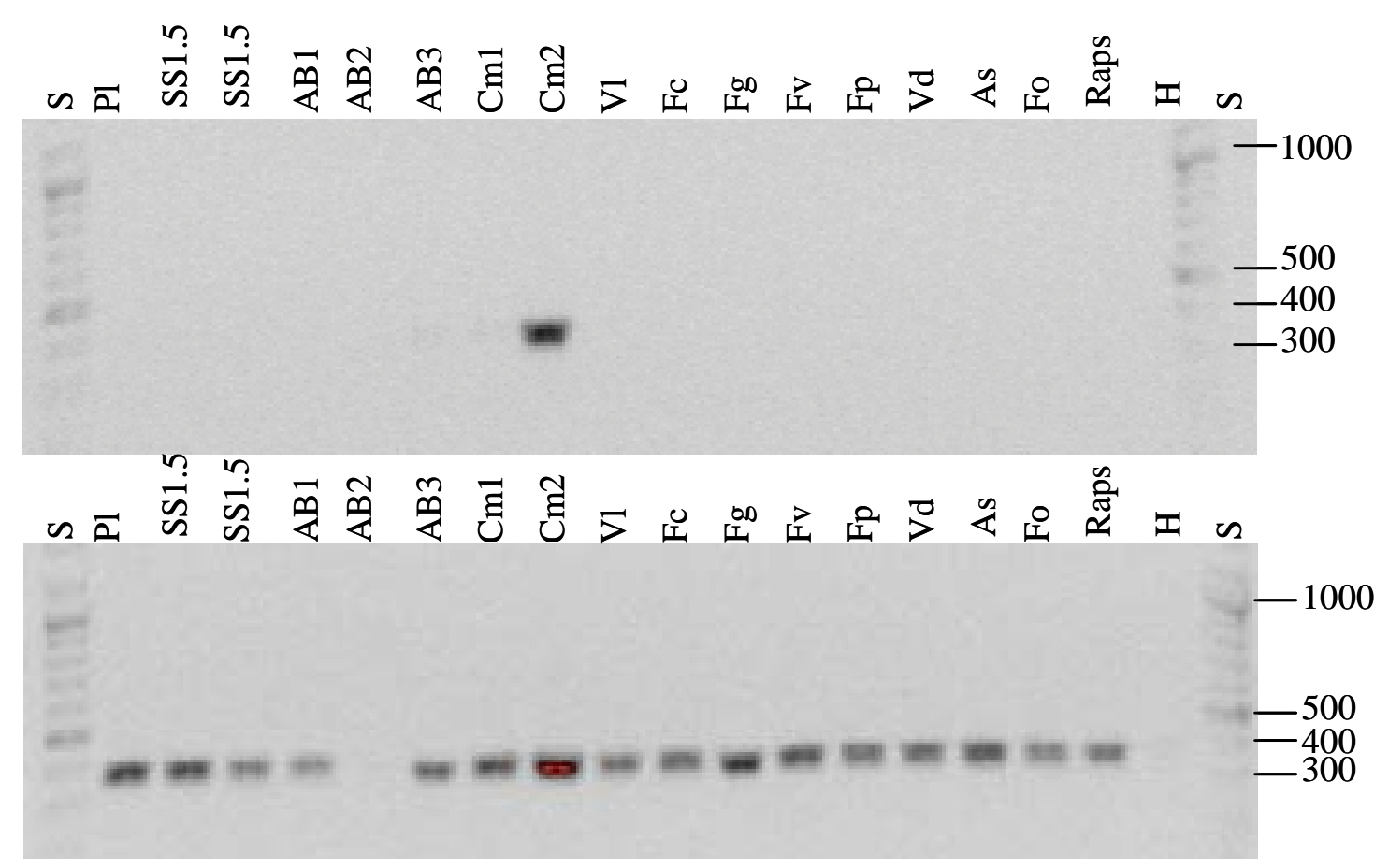

Abb. 2A: Spezifitätstest der M. ochracea Primer M.o 3 und M.o 4.1 Oben: Es wurden mögliche Kreuzreaktionen des Primerpaares zu DNA aus Phoma lingam (Pl), $S$ sclerotiorum (Ss1.5), Ackerboden (AB) C. minitans (Cm) V. longisporum (Vl), F. culmorum (Fc), F. graminearum (Fg), F. verticilloides (Fv), F. proliferatum (Fp), V. dahliae (Vd), Ascochyta graminea (As), F. oxysporum (Fo) und Raps getestet; unten: Positivkontrolle (Proben DNA + 100pg M.o DNA); S: Größenstandard 50bp Leiter; H: PCR Wasserkontrolle; 1,2\%iges Agarosegel. 


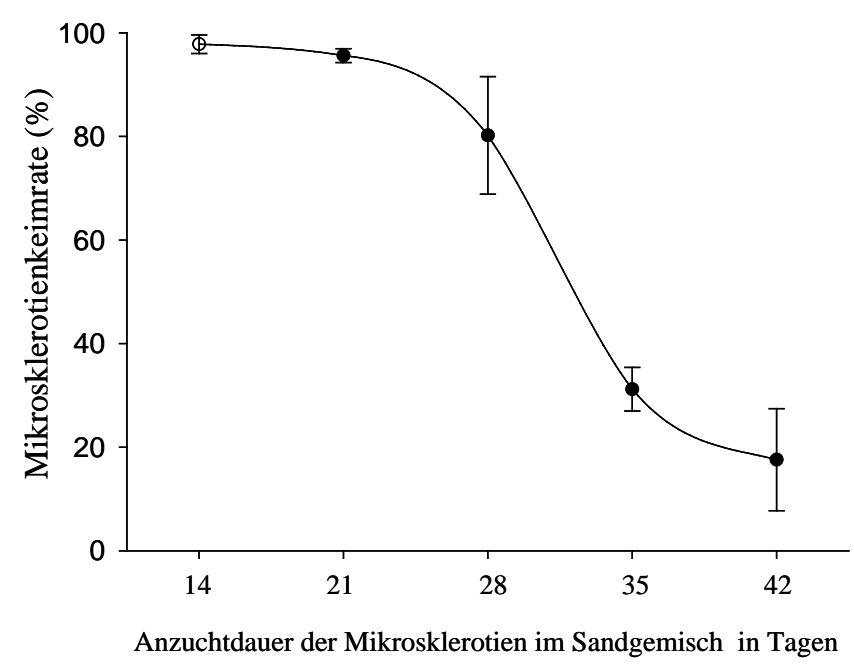

Abb. 3A: Mikrosklerotienkeimung von V. longisporum (Vl 43) in Abhängigkeit von der Mikrosklerotienanzuchtdauer im Roggenmehl-Quarzkies Gemisch. Dargestellt ist die Mikrosklerotienkeimrate (Fraktionsgröße 200-400 $\mu \mathrm{m}$ ) nach 14, 21, 28, 35, 42 Tagen Anzuchtdauer. Inkubation bei $20^{\circ} \mathrm{C}$ im Dunkeln, $\mathrm{n}=5$.

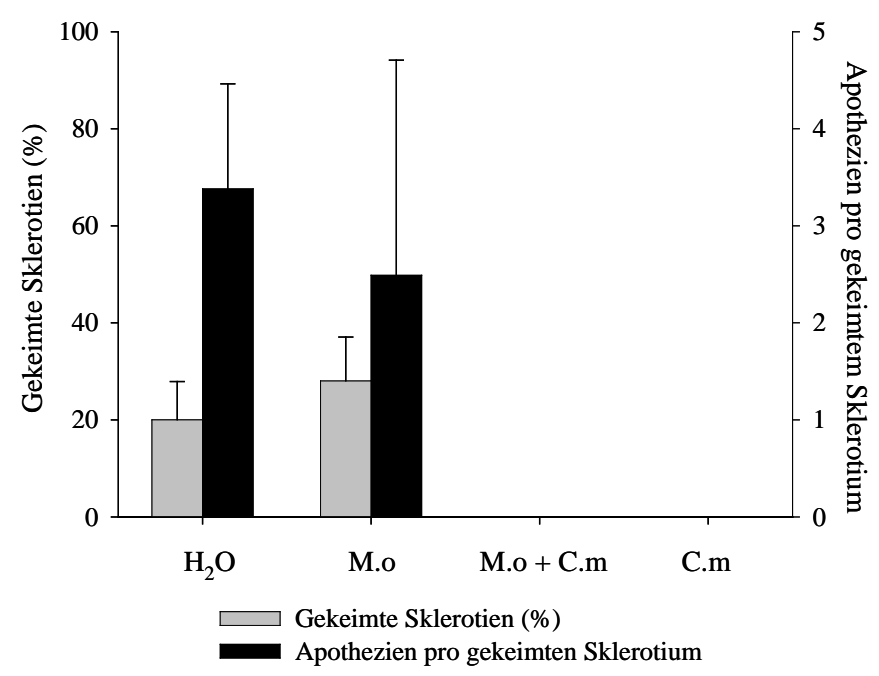

Abb 4A: Sklerotienkeimung von S. sclerotiorum in unsterilem Bodensubstrat. Dargestellt ist die Sklerotienkeimung (\%) und die Apothezienbildung (Apothezium pro gekeimten Sklerotium) 8 Monate nach der Tauchinokulation in Wasser $\left(\mathrm{H}_{2} \mathrm{O}\right)$, Sporensuspensionen von M. ochracea (M.o) $\left(1 \times 10^{6}\right.$ Sporen $/ \mathrm{ml})$, M. ochracea + C. minitans (M.o + C.m) (M.o $1 \times 10^{6}$ und C.m $1 \times 10^{6}$ Sporen $\left./ \mathrm{ml}\right)$ oder C. minitans (C.m) $\left(1 \times 10^{6}\right.$ Sporen $\left./ \mathrm{ml}\right)$; Inkubation von Oktober 2008 bis Mai 2009 in $3 \mathrm{~cm}$ Bodentiefe in unsterilem Bodensubstrat („Felderde“) in der offenen Vegetationshalle am Institut für Pflanzenpathologie und Pflanzenschutz, Göttingen; $\mathrm{n}=5$. 
ํํㄱ

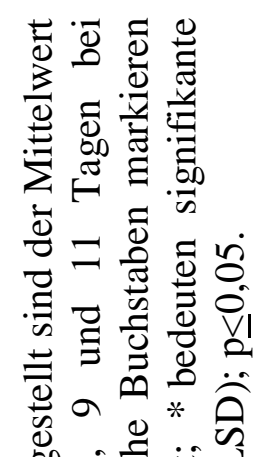

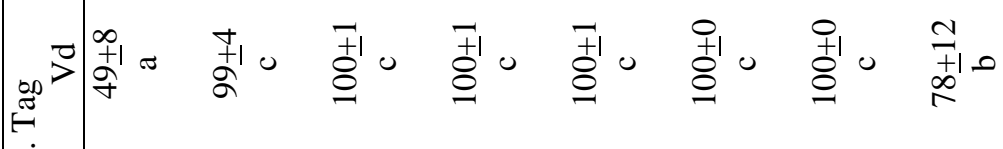

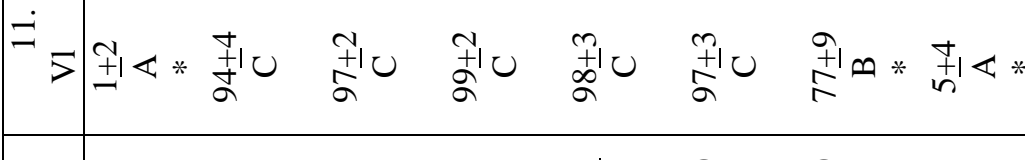

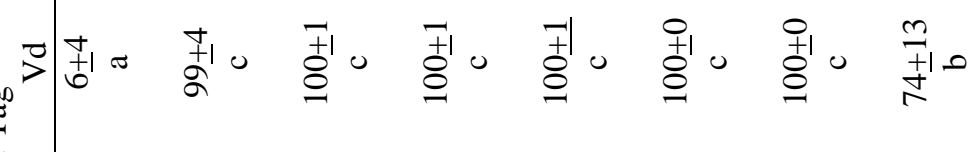

oمñ ปี

คี

กิ่

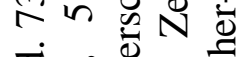

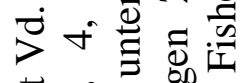

苟

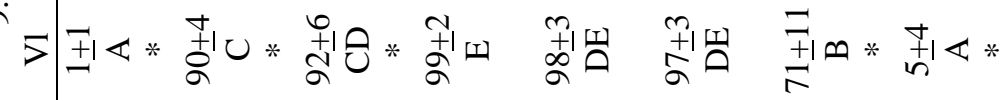

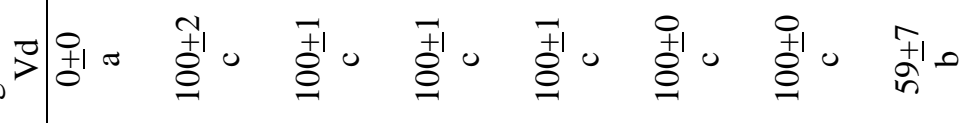

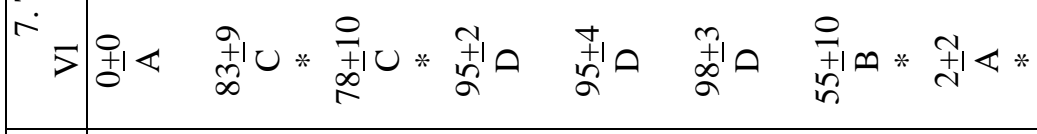

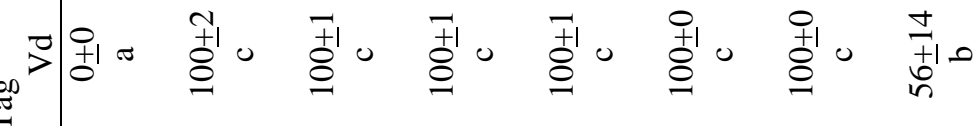

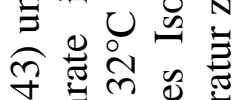

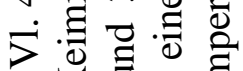

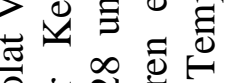

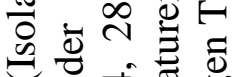

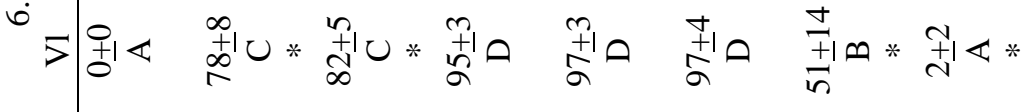
క $\stackrel{\sim}{\sim}$

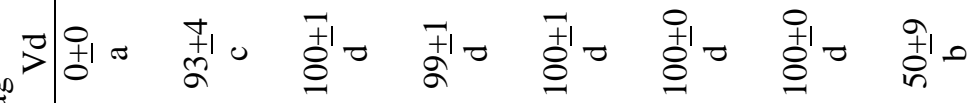

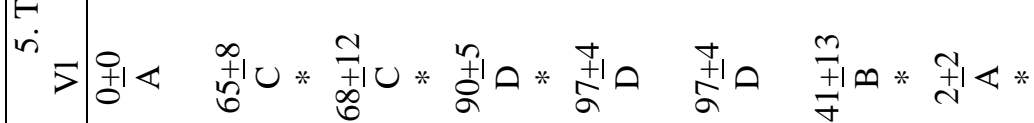

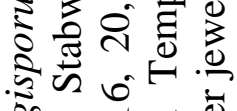
$\stackrel{5}{5} \stackrel{0}{0}$

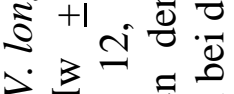
$\therefore \sum \infty \underset{2}{3} \infty$

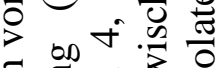
ฮี

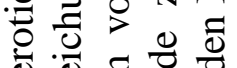

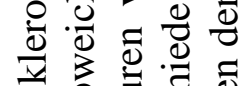

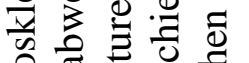
速

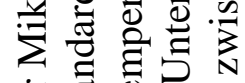

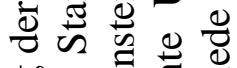

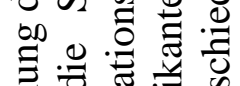

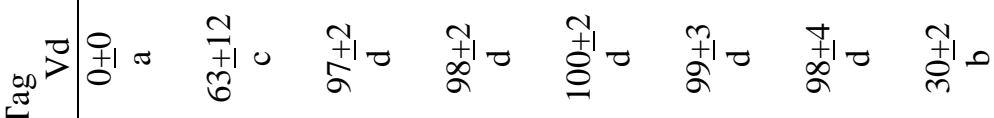

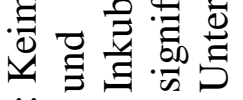

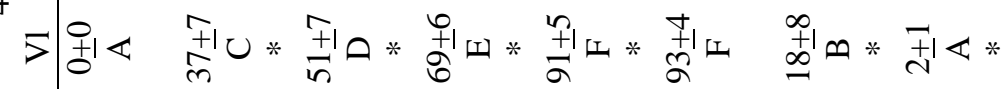

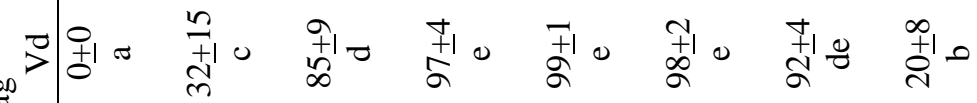

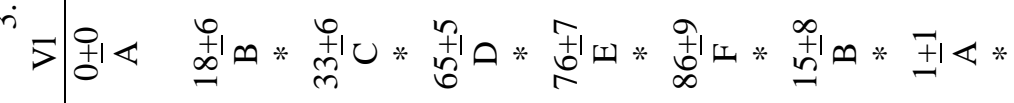

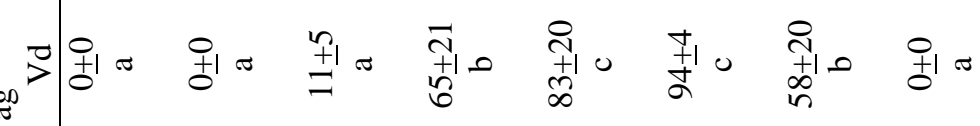

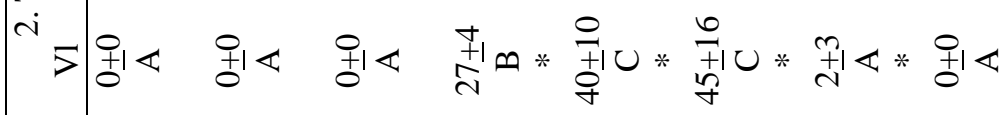
这

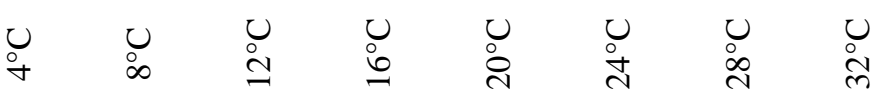


哂

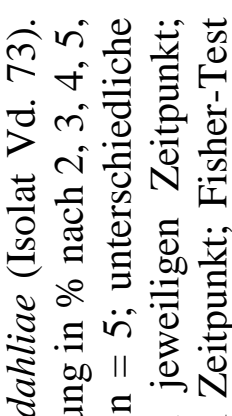

须寻寻

䒠会光

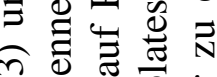

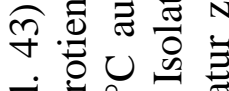

>

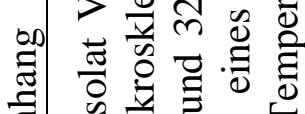

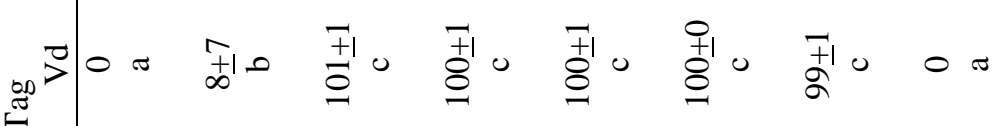

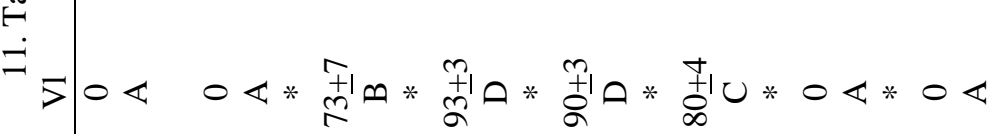

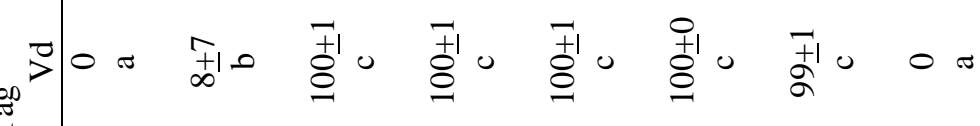
$\stackrel{0}{\circ}$

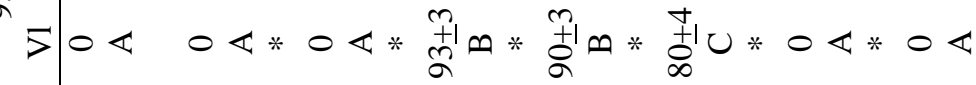

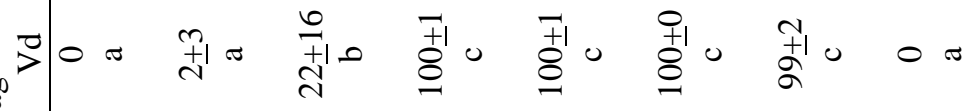

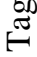

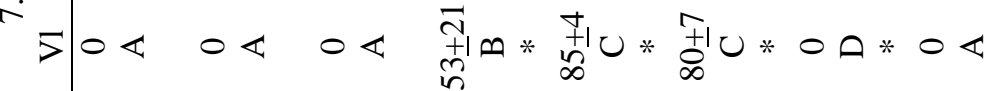

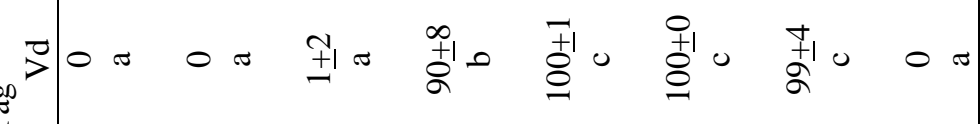

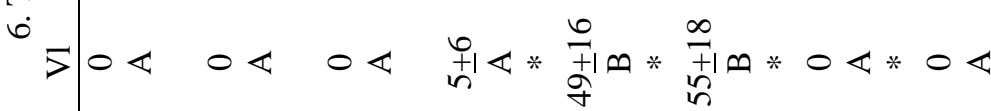

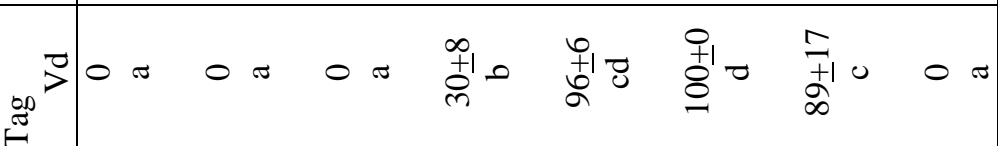

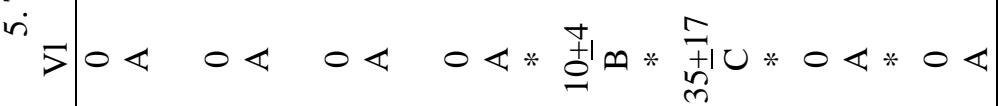

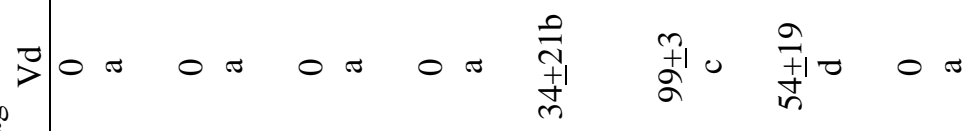
$\stackrel{+\infty}{\rightarrow}$

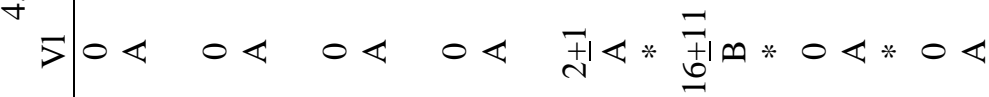
$\sum 00 * ย$ D) (n) $5000000 * 0 * 0$

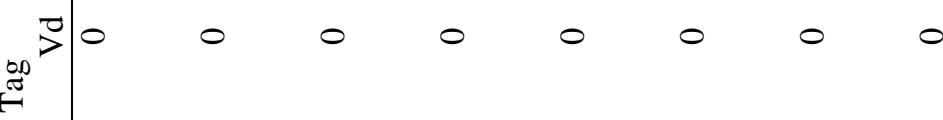

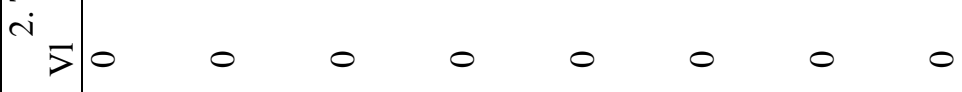
蒿

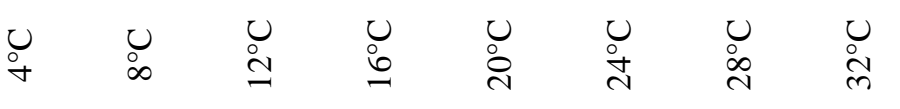




\section{Danksagung}

Mein ganz besonderer Dank gilt Herrn Prof. Dr. A von Tiedemann für die Überlassung des Themas, die Diskussionsbereitschaft sowie die gewährte Freiheit bei der Bearbeitung des Projektes.

Bei Herrn Prof. Dr. P. Karlovsky möchte ich mich für die Übernahme des Korreferates bedanken.

Herrn Dr. Birger Koopmann gilt mein besonderer Dank für seine Hilfsbereitschaft bei jeglichen Problemen und der Unterstützung bei molekularbiologischen Fragestellungen.

Silke Lippelt danke ich für die tatkräftige Unterstützung bei den Versuchsdurchführungen. Ohne ihre Hilfe wären viele Versuche in diesem Umfang nicht möglich gewesen.

Danken möchte ich Ruben Gödecke für die Hilfestellung bei statistischen Problemen und Mark Winter für seine Geduld und Hilfsbereitschaft.

Bei Evelin Vorbeck möchte ich mich für ihre Ratschläge aufgrund ihrer langjährigen Erfahrungen bedanken. Dagmar Tacke danke ich für die technische Unterstützung bei molekularbiologischen Arbeiten und ihre Freundschaft.

Bei allen Kollegen möchte ich mich für die angenehme und freundschaftliche Arbeitsatmosphäre bedanken.

Bedanken möchte ich mich bei meinen langjährigen Freunden Justus Böhm und Johannes Tucholski für ihre Hilfsbereitschaft und Unterstützung.

Ein ganz besonderer Dank gilt meiner Familie, die mich während meiner gesamten Studien- und Promotionszeit bedingungslos unterstützt hat.

Bei meiner Freundin Christina möchte ich mich für den Rückhalt in schweren Zeiten bedanken. 


\section{Lebenslauf:}

Name: $\quad$ Martin Stadler

Geboren am: $\quad$ 25. Januar 1982 in Regensburg

Familienstand: $\quad$ Ledig

1988-1992

Besuch der Grundschule in Thalmassing

1992-2001

Besuch des Goethe-Gymnasiums in Regensburg

Abschluss: Abitur

2001-2002

Zivildienst, Retex Werkstatt Burgweinting

2002-2004

Grundstudium der Agrarwissenschaften an der Georg-AugustUniversität, Göttingen

2004-2006

Hauptstudium der Agrarwissenschaften mit dem Schwerpunkt Pflanzenproduktion an der Georg-August-Universität, Göttingen

2006-2007

Anfertigung der Masterarbeit am Institut für Pflanzenpathologie und Pflanzenschutz zum Thema: „Interaktion zwischen Ramularia collo-cygni und der oxidativen Stresssituation bei Gerste“.

Juni 2007

Abschluss zum Master of Science

seit August 2007 Doktorand am Department für Nutzpflanzenwissenschaften, Fachgebiet Pflanzenpathologie und Pflanzenschutz der GeorgAugust-Universität, Göttingen. 